\title{
Assessment of the Candidate Markets for Liquid Boiler Fuels
}

December 1979

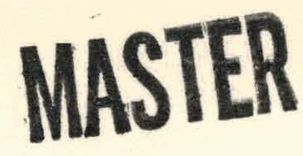

Prepared for:

U.S. Department of Energy

Assistant Secretary for Policy and Evaluation

Office of Advance Technology R\&D

Under Contract No. DE-AC03-79-70090 


\section{DISCLAIMER}

This report was prepared as an account of work sponsored by an agency of the United States Government. Neither the United States Government nor any agency Thereof, nor any of their employees, makes any warranty, express or implied, or assumes any legal liability or responsibility for the accuracy, completeness, or usefulness of any information, apparatus, product, or process disclosed, or represents that its use would not infringe privately owned rights. Reference herein to any specific commercial product, process, or service by trade name, trademark, manufacturer, or otherwise does not necessarily constitute or imply its endorsement, recommendation, or favoring by the United States Government or any agency thereof. The views and opinions of authors expressed herein do not necessarily state or reflect those of the United States Government or any agency thereof. 


\section{DISCLAIMER}

Portions of this document may be illegible in electronic image products. Images are produced from the best available original document. 
Ava1lable from:

National Technical Information Service (NTIS) U.S. Department of Commerce

5285 Port Royal Road
Springfield, Virginia 22161

Price: Printed Copy: $\$ 18.0$

Microfiche: $\$ 4.00$




\section{Assessment of the Candidate Markets for Liquid Boiler Fuels}

Prepared by :

Booz, Allen \& Hamilton Inc.

Bethesda, Maryland 20014

Under Contract No. DE-AC03-79-PE70090

Prepared for:

\section{U.S. Department of Energy}

Assistant Secretary for. Policy and Evaluation Office of Advance Technology R\&D

Washington,D.C. 20085

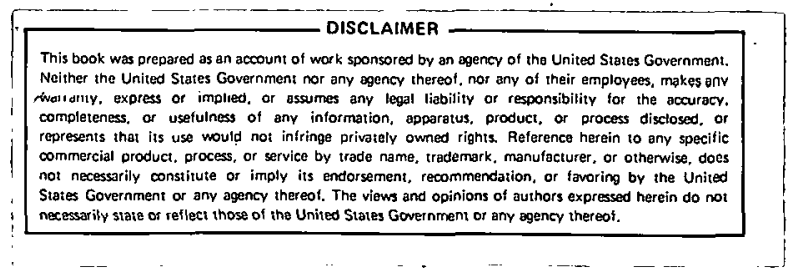




\section{NOTICE}

This report was prepared as an account of work sponsored by the United States Government. Neither the United States nor the United States Department of Energy, nor any of their omployees, makes any warranty, express or implied, or axsumes any legal liability or responsibility for the accuracy, completeness, or usetulness of any information, apparatus, product, or process disclosed, or represents that its use would not infringe privately owned rights. Reference herein to any specific commercial product, process, or service by trade name, mark, manufacturer, or otherwise, does not necessarily constitute or imply its endorsement, recommendation, or favoring by the Unired States Government or any agency thereof. The views and opinions of authors expressed herein do not necessarily state or reflect those of the United States Government or any agency thereof. 
T A B L E O F, C O N T E N T S

Page

Number

EXECUTIVE SUMMARY

1. INTRODUCTION

$1-1$

2. REVIEW OF THE DIRECT COAL IIQUEFACTION PROCESSES

$2-1$

3. POTENTIAL MARKETS FOR COAL LIQUEFACTION BOILER FUELS

$3-1$

4. THE POTENTIAL ENVIRONMENTAL HAZARDS OF BOILER FUELS PRODUCED FROM COAL LIQUEFACTION PROCESSES

$4-1$

5. REGULATORY ISSUES ASSOCIATED WITH MARKETING CONL LIQUEFACTION PRODUC'IS AS BOILER FUELS

6. INSTITUTIONAL ISSUES

$6-1$

7. COSTS OF DISTRIBUTION AND HANDLING COAL LIQUEFACTION BOILER FUELS

8. THE GOVERNMENT'S ROLE IN ACCELERATING MARKET DEVELOPMENT FOR COAL LIQUEFACTION PRODUCT BOILER FUELS

APPENDIX A - Supporting Data to Utility and Industrial Market Forecasts

APPENDIX B - The Potential Environmental Hazards of Boiler Fuels Produced From Coal Liquefaction Processes

APPENDIX C - Supplemental Analysis and Data Environmental Characteristics

APPENDIX D - The Utilization of Methanol as a Boiler Fuel

APPENDIX E - Organizations Interviewed

MARKETING BIBLIOGRAPHY

ENVIRONMENTAL BIBLIOGRAPHY 
$\begin{array}{lllllll}\text { I N D E X OF } & \text { E.X H I B I. T S }\end{array}$

Following

Page

I-1 U.S. Dependence on Oil for Electric Power, 1978

1.-2

2-1. Boiler Fuel Product Yield and Composition 2--2

2-2 Comparison of H-Coal Boiler Fuel With No.. 6. Fuel Oil

$2-7$

2-3 Physical and Chemical Analysis of 400$1,000^{\circ} \mathrm{F}$ and $400+^{\circ} \mathrm{F}$ EDS Fuel Oil Products From Illinois No. 6 Coal

2-4 Physical Handling Properties of SRC-II, No. 2 Fuel Oil, and No. 5 Fuel Oil 2-9

3-1 National Forecast of Primary Fuel Consumption by Electric Utilities, 1978-1990

$3-2$

3-2 National Electricity Generation Forecast, 1990

$3-2$

3-3 Total Market Size of Existing Oil-Fired and Gas Steam Plants, 1978

3-4 Summary of Regional Data of Residual Oil Inputs to U.S. Electric Generation

3-5 Regional Residual Fuel Oil Consumption, 1978 3-7;

3-6 Conceptual Generation Expansion Alternatives, 1985-2005

3-7 Summary of Fuel Consumption by Industrial Sector, 1975-19.90 
3-8 Summary of Regional Data of Total Residual Oil Consumption and Boiler Fuel Consumption in the Industrial sector

4-1 Typical Compositional Data for Bunker C Fuel 4-2

4-2 Capsule Summary of the Potential Hazards of Direct Coal Liquefaction Products Relative. to No. 6 Fuel Oïl

5-1 Impact of Various Regulatory Programs on Coal Liquefaction Market Development

6-1 Issues Affecting Marketability of Coal Liquefaction Products as Boiler Fuels Based on Perceptions of Actiors

$6-1$

6-2 Components of the Industrial Market System Involved in the Commercialization of Direct Coal Liquefaction Boiler Fuels

7-1 Evaluation of Transportation Market Barriers for Coal Liquids

7-2 Representative Range of Petroleum Transporation Costs by Various Modes

7-3 Possible Transportation Costs of Coal Liquids Shipments-Based on Costs of Residual oll Shipments

7-4 Existing Federal Oil Spill Liability and Compensation Programs

8-I Components of the Industrial Market system Involved in the Commercialization of Direct Coal Liquefaction Boiler Fuels

8-2 Impact Matrix of Government Actions That Could Enhance Coal Liquefaction Products' Marketability 
EXECUTIVE SUMMARY 
Liquid fuels can be produced from coal in a number of indirect and direct liquefaction processes. While indirect coal liquefaction has been proved commercially outside the United states, most attention in this country has focused on the direct liquefaction processes, which include the processes under examination in this report-namely, the Exxon Donor Solvent (EDS), the H-Coal, and the Solvent Refined Coal (SRC) II processes.

1. THIS REPORT HAS BEEN PREPARED TO ASSIST THE DEPARTMENT OF ENERGY'S POLICY PLANNING ON THE COMMERCIALIZATION OF DIRECT COAL LIQUEFACTION

A large body of data has been assembled by DOE and industry on the technology and economics of direct coal liquefaction. However, with attention shifting to the issues of full commercialization, there is an increasing awareness of potential logistical, regulatory, institutional, environmental, and safety issues that need to be resolved.

In the second quarter of 1979, the Department of Energy asked Booz, Allen \& Hamilton Inc. to conduct an assessment of the marketability of the products of direct coal liquefaction-focusing on the boiler fuel market in the period 1:9851990. Specifically, the study's key questions are:

- If the technology is proved and the economics appear attractive, will the products of direct liquefaction be compatible in the boiler fuel market?

- With respect to the findings on potential constraints or uncertainties, what are the implications for DOE policy?

The following section presents the major conclusions, after which each key finding is discussed.

2. MAJOR FINDINGS OF THE STUDY INDICATE THE PERCEIVED NEED FOR EXTENSIVE PRODUCT TESTING, HEALTH HAZARD RESEARCH, AND CONTROL SYSTEM DESIGN FOR PRODUCT HANDLING

The analysis is based on interviews with DOE and industry managers of coal liquefaction programs, market compatibility assessments by Booz, Allen \& Hamilton, and technical analysis. 
of physical, chemical, and biological issues by the Foster D. Snell Division of Booz, Allen \& Hamilton. The study draws six major conclusions:

\section{Fuel Characteristics}

The products of direct liquefaction appear-based on limited initial burn tests-to offer combustion characteristics similar to No. 6 residual fuél oil.

- Markets

Fuel oil demand for boiler fuel is forecast to decline by 1990. However, if economically compatible, there is a substantial potential boiler market opportunity for coal liquids, particularly for electric utilities in the Northeast, MidAtlantic, and South Atlantic regions.

Environmental and Safety

Analysis of preliminary data indicates that direct coal liquids offer, to a degree, the potential for greater environmental hazard than No. 6 fuel oil. While the indicated hazards can be controlled and managed with adequate safeguards, the lack of conclusive data precludes final judgment.

Transportation and Distribution

For the anticipated locations of early markets and initial liquefaction plants, the feasible transportation options are rail, barge, and potentially plpelines. The need for some degree of special handling is anticipated; however, specific requirements are not known at this time.

- Management and Coordination

The ultimate commercial marketability of direct coal liquids is likely to be constrained without a coordinated approach-by industry, utilities, Federal and state regulatory agenciés, public interest groups, and labor organizations-to the research, testing, and verification of environmental and safety characteristics. Procedures for handling, transportation, distribution, and use need to be designed and implemented. 
- $\quad$ Additional Testing

The aggressive development of synthetic fuels-as outlined in pending legislation-together with the preliminary nature of existing product test data, indicate a clear need for a comprehensive program of research in three areas:

- Combustion characteristics of various coal liquefaction products

- Environmental and safety characteristics, including toxicity and carcinogenicity

- Product handling procedures and safeguards for production, transportation, distribution, and end use.

Each major conclusion is discussed briefly in the following sections, based on detailed assessments in the main report.

3. THE PRODUCTS OF DIRECT LIQUEFACTION APPEAR TO OFFER COMBUSTION CHARACTERISTICS SIMILAR TO NO. 6 RESIDUAL FUEL OIL

Direct 1iquefaction includes two groups-catalytic and noncatalytic hydrogenation, and the fuel oil quality and yield is a function of the severity of the process operating conditions.

The H-Coal process, under development by Hydrocarbon Research Inc., is an example of catalytic hydrogenation. In this process, pulverized coal is mixed with a process-derived recycle solvent, and the resulting slurry is mixed with hydrogen gas, pretreated, and pumped to a reactor. Solvent extraction and donor solvent and catalytic hydrogenation take place in the reactor. At low severity (e.g., low temperature, low hydrogen pressure, and low residence time), the process yield is a very heavy oil which can be used as a substitute for No. 6 residual fuel oil. At higher severity conditions, the process can be converted to lighter distillate fractions.

The noncatalytic hydrogenation processes include the SRC-II process under development by Gulf and the EDS process under development by Exxon. Although it is well known that these processes utilize the inherent catalytic activity of the mineral matter in the coal, they often are called noncatalytic because no catalyst is added to the system. In 
these processes, pulverized coal is mixed with a recycle solvent and hydrogen. The mixture is preheated and fed to the reactor where the coal is converted to oil by hydrogenation and hydrocracking. The major product from both processes is a low-sulfur distillate fuel oil that can be used as a substitute for both No. 6 fuel oil and No. 2 fuel oil in utility and industrial boilers. Exhibit 1 indicates the boiler fuel yield and product composition from the three direct liquefaction processes addressed by this study:

H-Coal liquids have been produced in relatively small quantities by bench-scale systems and process development units. A pilot plant capable of processing 600 tons/day of coal into 2,000 barrels of liquid is now under construction. Actual production from the pilot plant will depend upon the severity of the operating conditions. At a low severity operation mode, the primary product is a replacement for No. 6 fuel oil. The higher heating value of $\mathrm{H}$-Coal boiler fuel is somewhat less than that of No. 6 fuel oil; however, this is not expected. to be a major market entry barrier. The most important marketability element will likely be the nitrogen content, which is approximately 60 percent greater than that of No. 6 fuel oil. Large-scale combustion tests of H-Coal boiler fuel will be required to ascertain any major problems associated with $\mathrm{NO}_{\mathbf{x}}$ emissions.

- EDS boiler fuel (blend of solvent and vacuum gas oil $400^{\circ}-1,000^{\circ} \mathrm{F}$ liquid) from Illinois. No. 6 was test burned in a 50-horsepower induslrial builes. The results of the test burn indicated that the $400^{\circ}-1,000^{\circ} \mathrm{F}$ coal liquid burned with less smoke than a 2.2 percent sulfur No. 6 residual fuel oil. The coal liquid burned with less particulates than a reference No. 6 residual oil and the particulate matter was below the EPA New Source Performance Standards' (NSPS). The particulate and smoke data infer that the $400^{\circ}-1,000^{\circ} \mathrm{F}$ EDS liquid product produced from Illinois No. 6 coal could be operable in dedicated existing utility and industrial boilers.

- A combustion demonstration test utilizing distillate fuel oil from the SRC-II process was conducted on a utility boiler at the $74 \mathrm{th}$. Street generating station of the Consolidated Edison Company of New York. Approximately 4,500 barrels of SRC-II boiler 
EXHIBIT I

Boiler Fuel Production Yield Fraction and Composition

\begin{tabular}{|c|c|c|c|c|}
\hline - & $\mathrm{H}$-Coal & $\begin{array}{c}\text { Exxon Donor } \\
\text { Solvent }\end{array}$ & SRC-II & $\begin{array}{c}\text { Ho. } 6 \\
\text { Fuel } 0 \text { il }\end{array}$ \\
\hline Distillation Range ${ }^{\theta_{F}}$ & $400-950$ & $700+$ & $350-900$ & \\
\hline Yield (bbl/Ton Dry Coal) & 0.6 & 0.7 & 1.5 & \\
\hline Specific Gravity & .968 & 1.1 & 0.99 & 0.9 \\
\hline Elemental Composition (wt \%) & & & & $\therefore$ \\
\hline $\begin{array}{l}\text { Carbon } \\
\text { Hydrogen } \\
\text { Sulfur } \\
\text { Nitrogen }\end{array}$ & $\begin{array}{c}90 \\
7.6 \\
0.22 \\
1.0\end{array}$ & $\begin{array}{c}88.5 \\
6.3 \\
0.79 \\
1.1\end{array}$ & $\begin{array}{r}87.9 \\
8.1 \\
0.3 \\
1.0\end{array}$ & $\begin{array}{l}86.6 \\
12.25 \\
0.28 \\
0.24\end{array}$ \\
\hline Heating Value Btu/lb. & 17,700 & 16,500 & 17,600 & 19,150 \\
\hline
\end{tabular}

SOURCE: Exxon Research and Engineering Company; A.shland 0il, Inc.; Gulf Mineral Resources Company. 
fuel were used in the test evaluation. To provide a comparison between characteristics for SRC-II fuel oil and typical utility fuel oils, data were also obtained with the No. 6 fuel oil currently used by Consolidated Edison. The SRC-II fuel oil tested was low in sulfur ( 0.22 percent). and ash ( 0.02 percent). The nitrogen content was relatively high ( 1.0 percent). The major finding of the test program was that boiler thermal efficiency levels with SRC-II were comparable to No. 6 residual fuel.

Although there were no major operational problems encountered during the test, the combustion of SRC-II fuel oil resulted in nitrogen oxide emissions levels approximately 70 percent greater than those for No. 6 residual fuel oil. Nitrogen oxide reductions were achievable, however, through combustion modifications. Nitrogen oxide reductions achievable were on the order of 33 percent for both SRC-II and No. 6 residual fuel oils. The test burn also indicated that particulate matter emissions were lower for the SRC-II fuel oil than for the No. 6 residual oil.

4. THERE IS A SUBSTANTIAL POTENTIAL BOILER FUEL MARKET OPPORTUNITY FOR COAL LIQUIDS IN 1990-PARTICULARLY FOR ELECTRIC UTILITIES IN THE EAST AND NORTHEAST

A potential utility boiler fuel market of 1.2 million $\mathrm{bbl/day}$ is forecast by Booz, Allen \& Hamilton for 1990 should coal-derived liquids replace conventional uses of INo. 6 residual oil and natural gas in these markets. In 1978, residual oil consumption alone was $1.6 \mathrm{million} \mathrm{bbl} / \mathrm{day}$. The substitution of coal liquids for residual fuel oil represents the largest near-term utility market for coal liquids. Similarly, natural gas consumption was $1.4 \mathrm{million} \mathrm{bbl} / \mathrm{day}$ of residual oil equivalent-clearly a large potential market for coal liquids.

By 1990, however, residual oil, distillate oil, and natural gas consumption is forecast to decline. As illustrated in Exhibit 2, residual oil is forecast to decline to 1.2 million bbl/day and natural gas consumption to decline to $250,000 \mathrm{bbl} / \mathrm{day}$ of residual oil equivalent. Although the utility industry will still be large enough to support a market for coal liquids, the decline in fuel oil and natural gas consumption by 1990 may limit the attractiveness of coal liquid development as a boiler fuel. 
EXHIBIT 2

National Forecast of Primary Fuel Consumption by Electric Utilities $1978-1990$

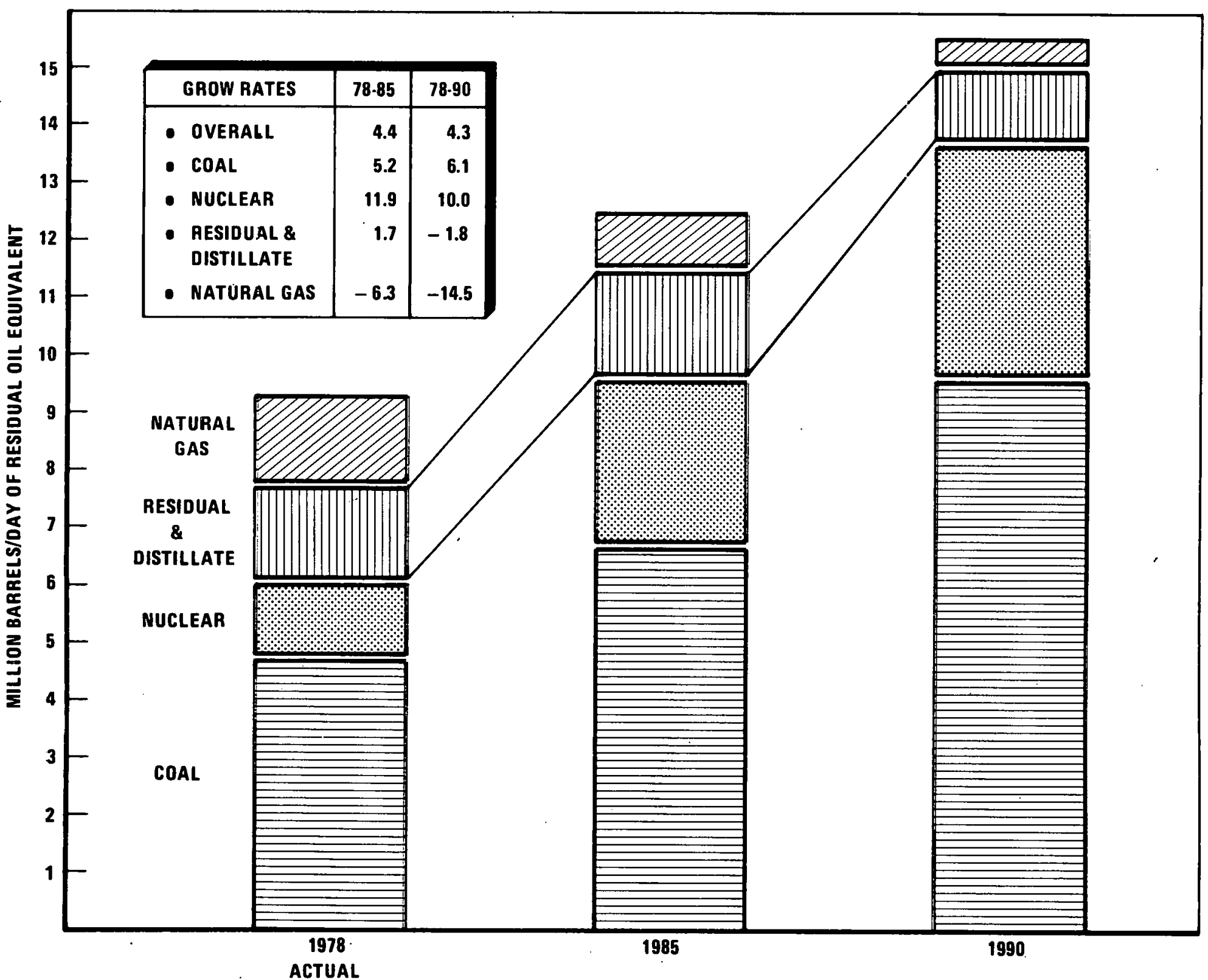

SOURCES: BOOz, Allen \& Hamilton.Inc.; and Energy Information Administration, DOE. 
Several factors are responsible for the decline in forecast fuel oil and natural gas consumption by 1990:

- Increased utilization of coal and nuclear power

- Planned and accelerated retirements of existing oil and gas plants

- Conversion of existing oil and gas plants to coal

- Lower utilization factors of existing oil and gas planto.

However, many utilities will encounter difficulties in switching from oil to such sources as coal, thereby increasing the attractiveness of coal liquids in certain utility regions.

Many oil-fired utilities, particularly in the Northeast, Atlantic, and West coast areas, will be limited in their ability to switch from oil to coal because of environmental constraints and economic considerations. If economically competitive coal liquids were available as a boiler fuel in significant quantities before 1990, then utilities in areas which could not convert to coal would probably be even willing to pay a cost penalty for coal liquids. This could act as an incentive to develop commercial coal liquid plants to supply utility boiler fuels to various regions of the country.

Five DOE utility regions have been selected as probable regional markets for coal liquids as boiler fuels based on market size. A summary of regional data on residual oil inputs to U.S. electrical generation is shown in Exhibit 3 . The five regions and their 1978 residual fuel oil consumption is graphically shown as Exhibit 4.

The five candidate regions account for 1.35 million $\mathrm{bbl} / \mathrm{day}$ (approximately 85 percent of the national residual fuel oil consumption). The remaining five regions-Midwest, Southwest, Central, Northwest, and North Central-account for 0.26 million bbl/day (approximately 15 percent of the national residual fuel oil consumption). Although the Midwest and Southwest could provide a potential market for coal liquids (with residual oil consumption of 115,000 and 125,000 bbl/day, respectively), these areas are not likely to be "first" markets for coal liquids based on interviews with representatives in each region. 


\section{EXHIBIT. 3}

Summary of Regional Data of Residual Oil Inputs

to U.S. Electric Generation

\begin{tabular}{|c|c|c|c|c|c|c|c|c|c|c|c|}
\hline \multirow{2}{*}{ Year } & \multicolumn{11}{|c|}{ Regional Utility Consumption in Thousand Barrels/Day } \\
\hline & New Eng & $\mathrm{NY} / \mathrm{NJ}$ & Mid-Atl & S. At]. & Midwest & S. West & Central & N. Central & West & N. West & Total \\
\hline 1978 & 203 & 310 & 233 & 286 & 115 & 125 & 17 & 3 & 316 & - & 1,608 \\
\hline $1990 *$ & 191 & 72 & 116 & 109 & 98 & 8 & 11 & - & 596 & - & 1,200 \\
\hline
\end{tabular}

H. * 1990 forecast data were obtained from supporting computer runs to Analysis Report, Energy Supply \& Demand in the Midterm: 1985, 1990, 1995, April 1979, DOE/EIA-0102/52. 
EXHIBIT 4

Regicnal Residual Fuel oil Consumption

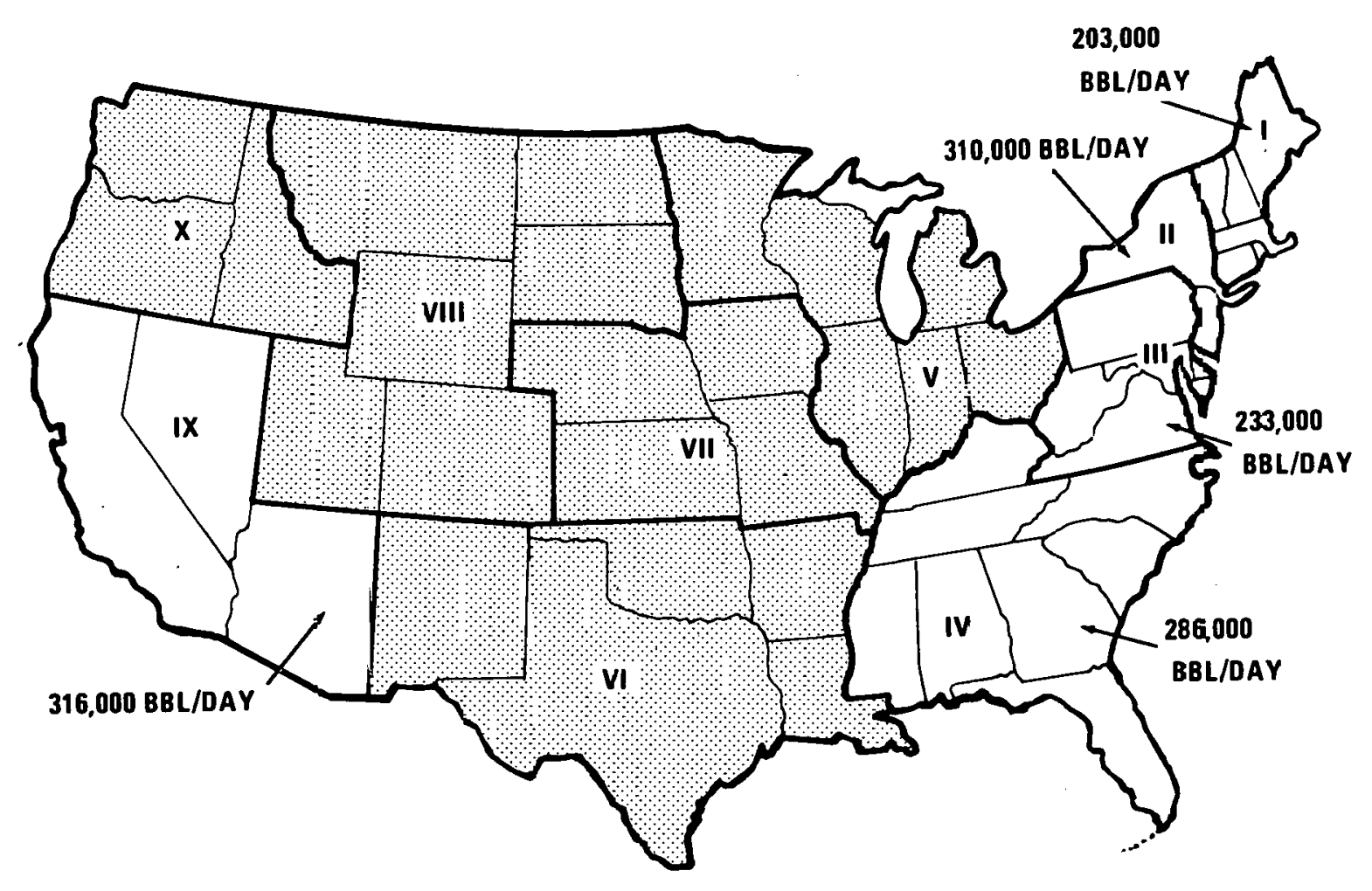

NOTES: (1) SHADED AREAS REPRESENT REG IONS WHICH CONSUMED LESS THAI 200,000 BBL/DAY OF RESSDUAL FUEL OIL IN 1978

(2) NON-SHADED REGIONS CONSUMED MORE THAN 200,000 BEL/DAY IN 1908 REPRESENTING APPROXIMATELY 85\% OF THE RESIDUAL OIL MARKET OF UTILITIES 
The New England and New York/New Jersey area offers the largest potential market area for coal liquids.

- It had a residual oil consumption of $513,000 \mathrm{bbl} /$ day in 1978 .

- By. 1990, the region is forecast to require 263,000 $\mathrm{bbl/day-still} \mathrm{a} \mathrm{large} \mathrm{potential} \mathrm{market} \mathrm{area} \mathrm{for}$ coal liquids.

- The New England and New York/New Jersey ar'ea is a particularly attractive market for coal liquids because utilities in this area will be restricted from switching away from oil to sources such as coal, based on regional environmental constraints and uneconomic capacity replacements for coal.

The Mid-Atlantic, South Atlantic, and West regions also consume large amounts of boiler fuels and could be attractive markets for coal liquids.

- The Mid-Atlantic region, like the Northeast, consumes a sizable amount of boiler fuels. In 1978, $233,000 \mathrm{bbl} / \mathrm{day}$ of boiler fuels were consumed by utilities in Pennsylvania, Virginia, Maryland, Delaware, and West Virginia. By 1990, the MidAtlantic region is forecast to require 116,000 $\mathrm{bbl} /$ day - a market large enough to support coal liquid plants.

- The Mid-Atlantic region is an attractive market for coal liquids because of its proximity to coal in Virginia and West Virginia. For example, an Appalachia minemouth coal liquids facility would require only train transportation to utilities in the Mid-Atlantic region, while deliveries to other regions would require more extensive transportation systems such as combination rail and barge transportation.

The West region (Arizona, Nevada, California, and Hawaii) is the single largest consuming region of boiler fuels. In $1978,316,000 \mathrm{bbl} / \mathrm{day}$ of boiler fuels were consumed by utilities in this region, mostly in California. By 1990, the West region is forecast to require $596,000 \mathrm{bbl} /$ day - a market which will grow over $250,000 \mathrm{bbl} / \mathrm{day}$ in the next ten years.

The industrial and Department of Defense markets for boiler fuels are not anticipated to provide major opportunities for initial penetration of coal liquids. 
- Residual fuel oil consumption in industrial boilers is small but is forecast to grow from approximately $100,000 \mathrm{bbl} /$ day in 1975 to between 200,000 and $250,000 \mathrm{bbl} / \mathrm{day}$ by 1990 .

- The Department of Defense consumes approximately $35,000 \mathrm{bbl} /$ day of residual fuel oil. The implication of the DOD market segmentation is that approximately 90 percent of DOD consumption of petroleum products is for transportation purposes (jet fuel, aviation gasoline, motor gasoline, and most middle distillates). Less than 10 percent of DOD consumption is for residual boiler fuel. In addition, the DOD boiler market is not centralized or localized in one region of the country, which would make marketability of coal liquids difficult.

Various regulatory programs will affect market developmont for coal liqucfaction boilcr fuels as shown in wibibit 5. The development of coal liquefaction technologies may be additionally constrainted by other regulations imposed to protect health, safety, and the environment. Various regulatory programs may involve higher capital and operating costs. These increased costs will be reflected in the price of the products produced. The magnitude of the price effects will be conditioned by the conclusions drawn from research currently in progress.

5. ANALYSES OF PRELIMINARY DATA INDICATE THAT DIRECT COAL LIQUIDS REPRESENT A POTENTIALLY GREATER ENVIRONMENTAL HAZARD THAN NO. 6 FUEL OIL. HOWEVER, THE INDICATED IIAZARDS CAN BE CONTROLLED WITI ADEQUATE SAFEGUARDS. THE LACK OF CONCLUSIVE DATA PRECLUDES FINAL JUDGMENT.

Hazards related to the three types of direct coal liquefaction products are similar because similar coal processing and operating conditions are used. Although the processes have some major system design differences, there are also some basic similarities among the processes and their operating conditions. Unit operations are similar as are operating temperatures, pressures, and yields for the three direct coal liquefaction processes. In addition, although analyses of the products are limited, similarities can be seen among the available data. The similarities indicate that the hazard from the products of the direct coal liquefaction processes cannot be sufficiently differentiated to cite differences among the individual processes. 


\section{EXHIBIT 5 \\ Impact of Various Regulatory Programs on Coal Liquefaction Market Development}

Regula tory Program

Clean Air Act, New Source

Performance Standards
Impact

0

\section{Remarks}

Governs $\mathrm{SO}_{2}, \mathrm{NO}_{x}$, and particulate matter emissions; permits and waivers may be granted for coal. 1 iquefaction; however, additional testing will be required to establish regulatory compliance.

\begin{tabular}{|c|c|c|}
\hline $\begin{array}{l}\text { Power Plant and Industrial } \\
\text { Fuel Use Act }\end{array}$ & $\theta$ & $\begin{array}{l}\text { Mandates conversions to coal from } \\
\text { oil and gas; temporary exemptions } \\
\text { may be granted for use of synthetic } \\
\text { fuels; however, implementing auth- } \\
\text { orities are not yet final, and syn- } \\
\text { thetic fuels are not yet available. } \\
\text { Long litigation is expected on } \\
\text { implementation. }\end{array}$ \\
\hline $\begin{array}{l}\text { Toxic Substances Control } \\
\text { Act }\end{array}$ & $\bullet$ & $\begin{array}{l}\text { Potential carcinogenecity of various } \\
\text { products may restrict their use. }\end{array}$ \\
\hline Clean Water Act & $\bullet$ & $\begin{array}{l}\text { Controls discharges of trace metals, } \\
\text { phenols, aromatic hydrocarbons, } \\
\text { sludge, and hydrogen sulfides. } \\
\text { Effluent standards may constrain } \\
\text { commercial development. }\end{array}$ \\
\hline $\begin{array}{l}\text { Resource Conservation and } \\
\text { Recovery Act }\end{array}$ & 1 & $\begin{array}{l}\text { Controls disposition of heavy tar } \\
\text { residues, wastelvater residues, slag, } \\
\text { coal dust, and refuse. Hazardous } \\
\text { waste disposal must comply with air } \\
\text { and water standards. }\end{array}$ \\
\hline $\begin{array}{l}\text { Surface Mining Control and } \\
\text { Reclamation Act }\end{array}$ & 0 & $\begin{array}{l}\text { Controis resource development and } \\
\text { may impede commercialization if coal } \\
\text { production cannot gear up to meet } \\
\text { coal liquefaction plant demands. }\end{array}$ \\
\hline $\begin{array}{l}\text { Occupational Safety and } \\
\text { Health Act }\end{array}$ & 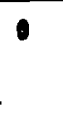 & $\begin{array}{l}\text { Controls toxic substances in the } \\
\text { work place. Strict implementation } \\
\text { may constrain technology. }\end{array}$ \\
\hline
\end{tabular}

Site-Specific Regulations:

- Endangered Species Act

- Fish and Wildlife Coordination Act

- Pivers and Harbors Act

- State regulations

- Local planning and zoning regulations
0 Not expected to pose a development barrier.
0 Not expected to pose a development barrier.
- lay have some impact depending on water shipments of coal liquids.
- State and local regulations are not yet developed. It is too early
- to determine ultimate impact al though strict zoning regulations could impede development.

LEGENO:

- Potential nigh impact

$\theta=$ Counj have an inpact

$D=$ Hot expected to have a market development impact 
The primary environmental area of concern with direct coal liquefaction products is worker health and safety. Dermal contact is the primary means of exposure to the product's carcinogenicity and toxicity, and workplace controls must be employed to minimize such exposure. A summary of the hazards of direct coal liquefaction products relative to No. 6 fuel oil is presented in Exhibit 6 . Summary results are as follows.

The environmental hazards of direct coal liquefaction products were assessed for both routine and episodal events to determine air and water pollution and ground contamination.

- The analysis shows few air pollution problems during routine operation, but good maintenance practices should be implemented to ensure employee safety frull rouline vapors and lcaks. Polycyclic arullalie liydroearbon emissione from coal liquids will be nominally higher than for No. 6 fuel oil but will be within acceptable limits. An incomplete combustion emission of polycyclic hydrocarbons could present problems. Test burns comparing No. 6 fuel oil and coal liquid products under upset conditions must be conducted to provide. definitive answers to this issue.

- Emissions of ashes and trace elements caused by incomplete combustion of direct coal liquefaction products should be similar to those of No. 6 fuel oil, but further testing is needed for technical certainty.

- Water pollution problems, caused by spills and disasters, are similar for coal liquefaction products and No. 6 fuel oil.

- Ground contamination is not expected to become a major problem because products could be transported and stored in closed systems. Leaks, pipeline breaks, and road and rail tanker accidents can be handled with current petroleum industry practices. Envịronment damage effects would probably need to be further researched, however.

The findings represent a preliminary judgment of current and future testing to determine the environmental hazards of coal liquefaction products. Our analyses show that worker safety and health will be the primary potential environmental concern. Dermal exposure to the products would have 


\section{EXHIBIT 6}

Summary of the Potential Hazards of Direct

Coal Liquefaction Producis Relative to No. 6 Fuel oil

Environmental Area

Worker safety \& Health

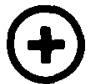

$\Theta$

$\stackrel{x}{x}$

Water Pollution

\begin{tabular}{c} 
Routine Events \\
$\begin{array}{c}\text { Potential Hazard } \\
\text { Relative to No. } 6 \\
\text { Fuel oil }\end{array}$ \\
\hline
\end{tabular}

Discussion

Controls would include good work practice and hygiene procedure

Current emission standards should be met-so $x$ less, ${ }^{N O} x$ higher measures analols to No. 6 Fuel Oil will be required

Routine clean-up and disposal of spills and leaks similar to No. 6 Fuel oil
$\Theta$

\section{Episodal Events \\ Potential Hazard Relative. to No. 6} Fuel oil

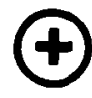

Dermal exposure during clean-up operations will have to be controlled to minimize hazard

Possible increase in polycylic aromatic compounds and particulates:more testing is needed

Tanker or barge accidents could have major environmental impact-similar to crude oil

Severe exposures must be controlled more stringently than No. 6 Fuel

\footnotetext{
(4) Greater Hazard Potential Than No. 6 Fuel oil

- Less Hazard potential Than No. 6 Fuel oil

(Approximately Equal Hazard Potential To No. 6 Fuel Oil
}

Source: Booz, Allen \& Hamilton Inc. 
to be greatly reduced in relation to normal handling procedures for conventional fuels. Additionally, there are several areas that need further evaluation such as biological testing of products, additional utility test burns, and detailed compositional data. The completion of these tests will further define the potential environmental hazards of coal liquefaction products.

6. FOR INITIAL PLANTS, THE FEASIBLE TRANSPORTATION OPTIONS ARE RAIL, BARGE, AND, POTENTIALLY, PIPELINES; SPECIAL HANDLING REQUIREMENTS ARE NOT KNOWN AT THIS TIME

Coal liquids could be distributed and marketed through an infrastructure similar to that utilized for residual fuel oil. In the early stages of commercialization, direct coal liquefaction planto will likcly bc oited in $\lambda$ ppalachia and Illinois, and the boiler fuels will be marketed in the Northeast and Mid-Atlantic areas. Additional market development could take place in the West as additional liquefaction plants are sited.

A qualitative evaluation of potential market barriers on four transportation modes-pipelines, barge, rail, and truck-is shown in Exhibit 7. As indicated, there are barriers-principally economic-associated with each mode of transporting coal liquids which must be resolved before fullscale coal liquids production takes place. These barriers would probably exist for any large-scale new "petroleum-type" liquids production from indigenous resources in these regions.

There are infrastructure barriers in all transportation/ distribution configurations except for rail transportation in the Northeast and Atlantic regions:

- Rail transportation is available in all systems. Rail transportation exists between the selected plant sites and markets; however, unit train transport in the West may be a barrier. Rail links exist in either direction from Wyoming, although rail traffic in an eastward direction may be cost prohibitive.

- Pipelines are not available currently in the candidate systems. There are no pipelines currently available to transport coal liquid boiler fuel from a Wyoming location to the west coast. Furthermore, there are no pipelines to transport coal liquids from Illinois or Appalachia to the East Cost. This 
EXHIBIT 7

Evaluation of Transportation Market Barriers for Coal Liquids

\begin{tabular}{|c|c|c|c|c|c|c|c|c|}
\hline \multirow{3}{*}{$\begin{array}{c}\text { Transportation } \\
\text { Mode }\end{array}$} & \multicolumn{7}{|c|}{ Potential Market Barriers } & \multirow{3}{*}{ Overall } \\
\hline & \multicolumn{4}{|c|}{$\begin{array}{c}\text { Existing } \\
\text { Infrastructure }\end{array}$} & \multirow[t]{2}{*}{ Economics } & \multirow[t]{2}{*}{ Environmental } & \multirow[t]{2}{*}{ Safety } & \\
\hline & 1 & 2 & 3 & 4 & & & & \\
\hline Pipeline & 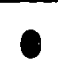 & 0 & 0 & 0 & $0-\theta^{*}$ & 0 & 0 & $0-0^{*}$ \\
\hline Barge & 0 & 0 & $\bullet$ & $\bullet$ & 0 & - & $\theta$ & $\theta$ \\
\hline Rail & 0 & 0 & $\theta$ & 0 & $\mathbf{0}$ & $\theta$ & 0 & $\theta$ \\
\hline Truck & 0 & $\theta$ & $\theta$ & $\theta$ & $\bullet$ & $\theta$ & 0 & - \\
\hline
\end{tabular}

* Depends on economics of constructing a new pipeline system specifically for coal liquefaction products.

Legend:

- May pose a significant barrier

- May pose a barrier

0 Does not pose a barrier

1 = A coal liquefaction plant in either Kentucky or West Virginia and candidate markets in the Northeast and Atlantic regions

2. = A coal liquefaction plant in Southern Illinois and candidate markets in the Northeast and Atlantic regions

$3=$ A coal liquefaction plant in the Hest and candidate markets in the Northeast and Atlantic regions

$4=A$ coal liquefaction plant in the West and candidate markets in California 
may pose a marketing barrier in the event alternative modes of transport are not available because of physical constraints or economic considerations.

- Truck transportation is not a likely possibility. Truck transport may be available in each case; however, each $50,000 \mathrm{bbl} / \mathrm{day}$ liquefaction plant would require approximately 750 tank trucks. Tank trucks will likely be eliminated as a candidate mode because costs are expected to be prohibitive due to the distance between plants and markets.

- Limited barge shipments could take place along the East coast. Barge movement could take place between an East Coast port and a New York or New England market. The coal liquids could be shipped via rail from the liquefaction plants to Baltimore and barged to the consumption plant.

Since only a relatively small amount of coal liquids have been moved for test in utility and industrial boilers, the lack of attendant problems may not be indicative of those of transporting 50,000-100,000 bbl/day, which is ultimately envisioned. A whole scale increase of coal liquids transportation has marketing implications with respect to:

- Availability of rail cars

- Adequacy and availability of railroad beds to transport coal liquids from plant sites to candirate markets

- Adequacy or avallability of pipelines to carry coal liquids from plant sites to candidate markets

- Adequacy of storage facilities at end-use locations.

These factors, important for virtually any major expression of domestic energy supplies, warrant additional evaluation to completely ascertain transportation and handling requirements for these fuels for the 1985-1990 timeframe.

7. THE PRELIMINARY NATURE OF EXISTING DATA ON ENVIRONMENTAL, SAFETY, AND INSTITUTIONAL ISSUES INDICATES THE NEED FOR A COMPREHENS IVE RESEARCH PROGRAM

Data on the coal liquefaction products are limited and often inconsistent, since the various technologies are at different stages of development. 
- The epidemiological data available from the Institute, West Virginia liquefaction plant (operated during 1952 to 1960) may not be applicable to the products of current direct coal liquefaction processes.

- Toxicological testing programs on SRC-I products were carried out by Industrial Bio-Test Laboratories. However, this laboratory is virtually shut down and the program status cannot be reported.

- Test burn data are available but limited because of short-term duration and brief analyses performed.

- Chemical analyses of the products from each process are generally unavailable. The chemical components of coal liquids contain numerous complex molecules, with high boiling points, which are difficult to analyze.

- Analytical techniques are still being developed to analyze the chemical groups and compounds found in coal liquefaction products.

- In general, analyses for polycyclic aromatics, sulfur compounds, nitrogen heterocyclics, monocyclic aromatics, inorganics, and insolubles must be interpreted from other data and are only qualitative in nature or are unavailable.

It is recognized that extensive research is currently in progress. The unresolved questions regarding regulatory and institutional matters warrant additional analyses and evaluation on a coordinated basis, as discussed in the following section.

8. RESEARCH, TESTING, AND VERIFICATION PROGRAMS NEED TO BE HIGHLY COORDINATED AMONG NUMEROUS ORGANIZATIONS : FOCUSED REVIEW AND MANAGEMENT IS CALLED FOR

The large number of organizations involved in the commercialization process of coal liquids argues in favor of a well-coordinated research program. The potentially large number of institutional constraints to the marketability of coal liquefaction boiler fuels may enhance, prevent, or delay the commercial development of the process technologies. The pace of coal liquids market development will be dependent 
on cooperation between the industrial and governmental sectors. A complex and often conflicting system is currently in place which will have a high impact on the timing of commercialization of coal liquefaction technology:

- Three main groups are encouraging and supporting commercialization:

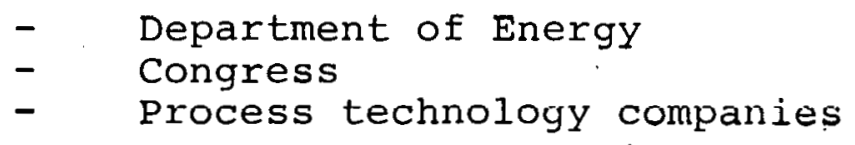

- Other groups with legitimate interests are involved in the commercialization process:

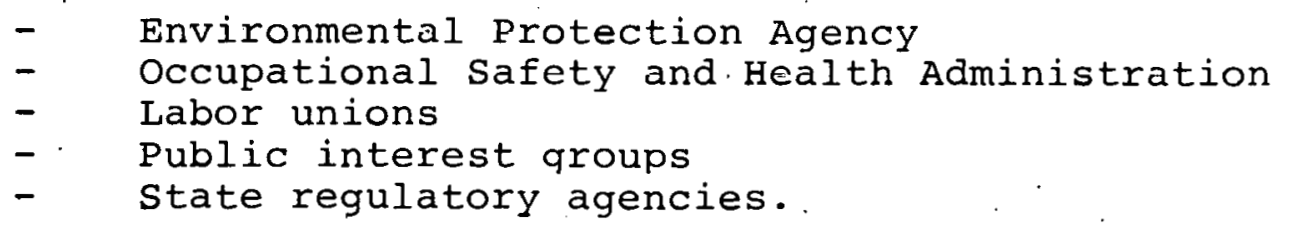

Commercialization will be constrained by the current lack of adequate facts to satisfy the complex approval system. Thus, there are three important tasks that the Department of Energy should consider initiating:

- A major review of all direct coal liquefaction research to ascertain opportunities for enhancing the resolution of potential regulatory, institutional, and logistical conflicts

- An aggressive test burn program for all three direct coal liquefaction boiler fuels to confirm combustion suitability

- An aggressive researeh program to idenlify liej necessary product handling procedures and safeguards for production, transportation, distribution, and end use for direct coal liquefaction. boiler fuels.

As with any new energy system, even if conceptually economically competitive, the basic technical feasibility and environmental suitability must be demonstrated before fullscale commercialization can be expected to take place in the United states. 
CHAPTER 1

INTRODUCTION 
CHAPTER I

INTRODUCTION

The Department of Energy (DOE) is currently reviewing the potential for commercial development of technologies that produce petroleum type oil and gas from coal. DOE is interested in the commercial development of emerging technologies because they have the potential to reduce the growing dependence on foreign energy resources and to add to the domestic energy base. The technologies to which DOE is focusing include coal gasification and coal liquefaction systems.

Although first-generation coal gasification and coal liquefaction technologies are technologically proven, the prices for products are significantly higher than conventional fuels in mid-1979. Also, the emerging gasification and liquefaction industries may be constrained by technical uncertainties of advanced processes, unknown regulatory standards, potential institutional and logistical barriers, and potential environmental hazards. The purpose of this study is to examine some of the details of the potential markets for coal-derived liquids-specifically boiler fuels.

Coal liquefälion pruduces fuels which include low-ash, low-sulfur boiler fuels suitable for electric power and steam generation and high-grade transportation fuels and chemical feedstocks. The Federal Government and the process technology companies are advancing direct coal liquefaction technologies to the pilot plant stage and toward demonstration facilities. DOE's present goal is to provide useful products for the marketplace from three processes-the Exxon Donor Solvent (EDS) Process, the H-Coal Process, and the Solvent Refined Coal-II Process (SRC-II). It is expected that one or all of these processes will eventually form the basis for a United States' coal liquefaction industry. DOE is not currently supporting research and development programs for indirect liquefaction technologies.

Coal liquefaction market development may proceed slowly as economic feasibility improves. Furthermore, technological questions must be resolved, environmental questions need to be answered, and institutional barriers need to be removed. Commercial availability of coal liquefaction products could well be on the order of 100,000 to 200,000 barrels of petroleum equivalent per day in 1990. This 
production level could be achieved if demonstration facilities proceed as scheduled and commercial scale-up takes place without the negative impact of environmental, regulatory, and institutional issues.

The Department of Energy asked Booz, Allen \& Hamilton Inc. to assess the market potential for coal liquefaction products as boiler fuels because this particular market segment may offer some early potential coal liquefaction commercialization. Booz, Allen assessed only coal liquefaction boiler fuels as a replacement for No. 6 residual fuel oil and did not evaluate the other types of coal liquids fuels such as transportation or turbine fuels.

It is recognized that certain direct coal liquefaction products could be utilized by the electric utility industry in stationary combustion turbines. This area may represent a significant market segment for coal-derived liquids in the 1990s. This report, however, focuses on the electric utility and industrial boiler markets realizing that other areas may also offer significant long-term opportunities.

The DOE requested BOoz, Allen to determine the potential size of the boiler fuel market in 1980-1990 and to identify the environmental and institutional issues that may impede technology development for the boiler fuel market.

Coal-derived liquid fuel oils could supplant residual fuel oils currently utilized in the utility and industrial sectors. The utility sector might be an early candidate market because of its high dependence on imported fuel oil. Exhibit I-1 shows 1978 electrical generating dependency on oil. Note that the significant areas where import dependency is the greatest are New England, Middle Atlantic, South Atlantic, and Pacific regions.

This study does not directly address a number of the economic aspects of commercialization. The focus of the study was to assess the marketability of liquid boiler fuels in 1990 and assess the industrial marketplace to identify possible commercialization barriers. The DOE recognizes that the economic environment will influence market development and, as such, has other studies underway to assess the required economic incentives necessary. for technology commercialization. 
U.S. Dependence on Oil for Electric Power, 1978

(By Regions, Electricity Generated By Oil as

a Percent of Total Electricity Generated)

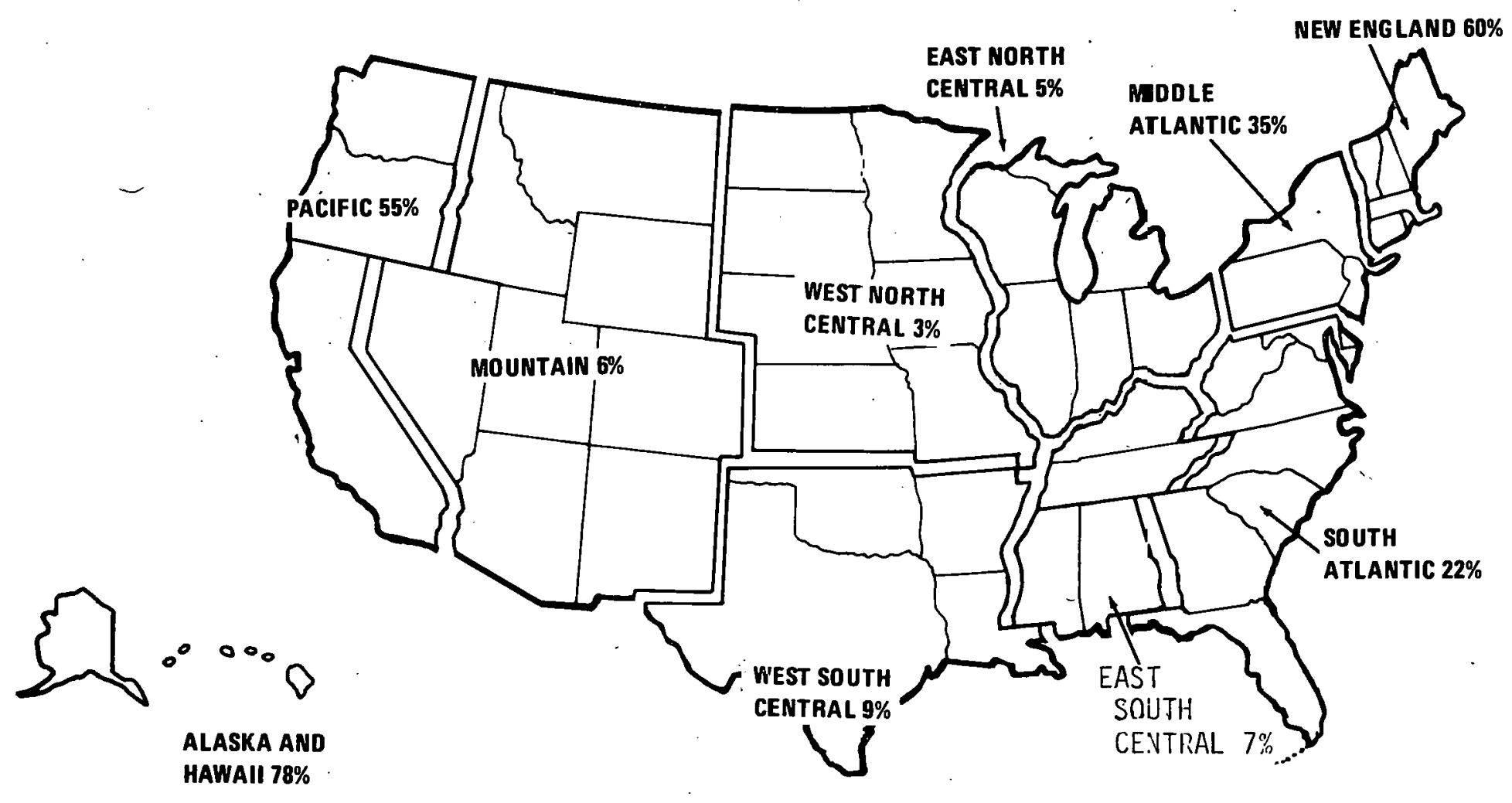

SOURCE: ENERGY INFORMATION ADMINISTRATION 
In view of the work scope selected by DOE for this study, an economic comparison of direct coal liquefaction products with alternative fuels was not undertaken nor did Booz, Allen evaluate the market potential for other types of fuel that could be produced with the direct coal liquefaction technologies.

The balance of this introduction is presented in the following five sections:

- Purpose of the study

- Scope of the study

- Approach of the study

- Overview of organizations interviewed

- Overview of the contents of the report.

1. THE PURPOSE OF THE STUDY WAS TO DETERMINE THE CANDIDATE MARKETS FOR DIRECT COAL LIQUEFACTION PRODUCTS FOR BOILERS FUELS DURING THE TIME FRAME 1985-1990

The objectives of the study were to:

- Compare the boiler fuels of direct coal iquefaction with residual fuel oil (No. 6 fuel oil):

- Physical characteristics

- Environmental hazards, such as:

- Carcinogenic characteristics

- Toxic hazard characteristics.

- Determine whether a boiler fuel market would exist for the coal liquefaction products given their physical characteristics and potential environ-. mental hazards.

- Determine the advantages of utilizing methanol as a boiler fuel on a continuous basis in commercial boilers utilizing existing technology. The utilization of methanol as a boiler fuel is examined in Appendix D.

- Identify the potential regional candidate markets for direct coal liquefaction products as liquid boiler fuels.

- Determine the distributing and handling costs associated with marketing coal liquefaction products as liquid boiler fuels.

- Determine the current regulatory issues associated with the marketing of coal liquetaction products as boiler fuels. 
- Determine and evaluate other institutional issues associated with the marketing of direct coal liquefaction products as boiler fuels.

2. THE SCOPE OF THIS STUDY FOCUSED ON THE POTENTIAL USE OF DIRECT COAL LIQUEFACTION PRODUCTS AND METHANOL AS BOIIER FUELS IN TWO MARKETS

The study focused on utility and industrial boilers as potential markets. Three direct coal liquefaction processes were incorporated in the study-Exxon Donor solvent (EDS), $\mathrm{H}$-Coal, and Solvent Refined Coal-Liquid (SRC-II). 'l'he use of methanol as a boiler fuel was evaluated to determine potential combustion advantages.

3. THE STUDY APPROACH WAS TO INTEGRATE PUBLIC AND PRIVATE PERCEPTIONS OF THE UTILIZATION OF DIRECT COAL LIQUEFNCTION BOILER FUELS AND TO DETERMINE THE LIKELY CANDIDATE MARKET SEGMENTS FOR SUCH PRODUCTS

Data and information to support this study were obtained from three main sources:

- Existing literature and reports in the public and private sectors

- Interviews with Department of Energy (DOE) and other public officials.

- Interviews with the process technology companies, leading utilities involved in coal liquefaction fuels research, industrial boiler manufacturers, boiler owners, pipeline companies, railroad and other transportation companies, investment bankers, labor union officials, oil companies, and other cncrgy organizationc.

Nine types of information were obtained:

- Status of coal liquefaction technology development

- Anticipated markets for coal liquefaction products to be used as boiler fuels

- Statistical data from which boiler fuel market forecasts were developed

- Names of process technology participants and their respective market strategies

- Utility management perceptions on the utilization of coal-derived liquids for boiler fuels 
- Industrial sector management perceptions on the utilization of coal-derived liquids for boiler fuels

- Environmental data

- Federal policy implications:

- Executive Branch

- Legislative Branch

- Financial institution perceptions on the development of a commercial coal liquefaction industry.

The data and information were analyzed to forecast the potential market for direct coal liquefaction products to be used in boiler fuels and to identify likely candidate markets for these fuels.

The potential environmental risks associated with marketing direct coal liquefaction products were evaluated in the context of whether or not such risks were manageable.

4. THE PRIVATE SECTOR COMPANIES WHICH PROVIDED INPUT TO

THIS STUDY REPRESENT THE CORE OF THE DIRECT COAL

LIQUEFACTION PROCESS TECHNOLOGY COMPANIES

This study focused on three direct coal liquefaction process technologies. These technologies are being supported individually by three different groups:

- SRC-II :

- Developed by Gulf Oil Corporation (Pittsburg \& Midway Coal Mining Co.)

- Cosponsors are the Department of Energy (DOE), the Electric Power Research Institute (EPRI), and Southern Services

- H-Coal:

- Developed by Hydrocarbon Research, Inc.

- Cosponsors are DOE, EPRI, Ashland Oil, Standard Oil Company (Indiana) (Amoco), Mobil, Continental Oil Company (Conoco), and the state of Kentucky 


Exxon Donor Solvent:
$-\quad \begin{aligned} & \text { Developed by Exxon Research and Engineering } \\ & \text { Company }\end{aligned}$
$-\quad \begin{aligned} & \text { Cosponsors are DOE, EPRI, and Phillips } \\ & \text { Petroleum Company. }\end{aligned}$

At least 12 utilities in New England and the MidAtlantic region are interested in utilizing direct coal liquefaction boiler fuels. They include three of the largest East Coast utilities:

- Consolidated Edison

- Boston Edison

- Baltimore Gas and Electric.

In total, 86 organizations were interviewed and provided information useful to the development of this sludy. A list of the organizations interviewed is included as Appendix $E$ to this report.

5. THIS REPORT PROVIDES THE DEPARTMENT OF ENERGY WITH A MARKET FORECAST FOR THE UTILIZATION OF DIRECT COAL LIQUEFACTION PRODUCTS AS BOILER FUELS

This study. focused on three key factors which were evaluated to assess the acceptability of the market for coal liquefaction boiler fuels:

- Product demand to determine whether a user need existed

- Product specification to determine likely market acceptability of the fuel

- Póténtial marketing costs for cual liqueldulivil boiler fuels compared with conventional fuels.

The study also focused on the potential environmental risks at the end-use level that are associated with the marketing of direct coal liquefaction products. (See Appendix B.)

The study identified the potential size' of the market for direct coal liquefaction products used as boiler fuels and identified candidate market segments, given that coal liquids would be economically. competitive. There are issues that will need additional analyses before a market for coal liquefaction boiler fuels can be established. 
The balance of this report presents the findings and conclusions of the study:

- Chapter 2: Beview of the Direct Coal Liquefaction Processes :

- SRC-II Process

- H-Coal Process

- Exxon Donor Solvent Process

- Chapter 3: Potential Markets for Coal Liquefaction Boiler Fuels:

- Ittility demand forccasts

- Industrial sector demand forecasts

- Chapter 4: The Potential Environmental Hazards of Boiler Fuels Produced From Coal Liquefaction Processes

- Chapter 5: Regulatory Issues Associated With Marketing Coal Liquefaction Products as Boiler Fuels

- Chapter 6 : Institutional Issues

- Chapter 7: Costs of Distribution and Handling Coal Liquefaction Boiler Fuels

Chapter 8: The Government's Role in Accelerating Market Development for Coal Liquefaction Product Boiler Fuels. 
CHAPTER 2

REVIEW OF THE DIRECT COAL LIQUEFACTION PROCESSES 
The direct liquefaction of coal is carried out by slurrying coal in a process derived oil. This oil may or may not be a coal hydrogenator at this stage of the process. The resultant mixture is reacted with hydrogen at high pressure and moderate temperature to form liquid hydrocarbons. The unreacted coal and ash are removed from the product. The unused coal can be gasified to produce the hydrogen required by the process.

The boiler fuels derived from direct coal liquefaction processes can potentially replace refined petroleum products in two distinct markets-electric utilities power generation, and industrial steam generation. The development of direct coal liquefaction processes can therefore provide for increased production of liquid fossil fuels to alleviate the United States' import dependency by introducing an alternative type fuel oil to replace the large volumes of residual oil entering the United States from offshore.

1. THE DIRECT COAL LIOUEFACTION APPROACH IS THE MAJOR TIIRUST OF TIIE DEFARTMENT OF ENERGY'S COAL LIQUEF PROGRAM

The DOE direct coal liquefaction program focuses on the development of three processes - the Exxon Donor Solvent (EDS) Process, the H-Coal Process, and the Solvent Refined Coal-II (SRC-II) Process. This section provides an introduction to the technologies, based on generally available information.

Efficiencies of the direct liquefaction process range from 65 to 70 percent. Product yields are 2.5 to 3 barrels of coal-derived liquids (fuel oil equivalent) per ton of coal. The fuel oil yield is a function of the severity of the operating conditions programmed into the process. Direct liquefaction includes two groups-catalytic and noncatalytic hydrogenation.

Catalytic hydrogenation includes the $\mathrm{H}-\mathrm{Coal}$ Process under development by Hydrocarbon Research Inc. Pulverized coal is mixed with a process derived recycle solvent and the resulting slurry is mixed with hydrogen gas, pretreated and pumped to a reactor. Solvent extraction, donor solvent hydrogenation, and catalytic hydrogenation take place in the reactor. At low severity, e.g., low temperature, low hydrogen pressure, and low residence time, the process yield is a 
very heavy oil which can be used as a substitute for No. 6 residual fuel oil. At higher severity conditions, the process yield can be converted to lighter distillate fractions.

The non-catalytic hydrogenation processes include the SRC-II process under development by Gulf and the EDS process under development by Exxon. Although it is well-known that these processes utilize the inherent catalytic activity of the mineral matter in the coal, they often are called noncatalytic because no added catalyst is used. In these processes, pulverized coal is mixed with a recycle solvent and hydrogen. The mixture is preheated and fed to the reactor. where the coal is converted to oil by hydrogenation and hydrocracking. The major product from both processes is a lowsulfur distillate fuel oil which can be used as a substitute for both No. 6 fuel oil and No. 2 fuel oil in utility and industrial boilcrs. Exhibit 2-l indicates the boiler fuel yield and product composition from the three direct liquefaction processes addressed by this study.

(1) The H-Coal Process Is a Catalytic Hydrogeneration Concept Developed by Hydrocarbon Research, Inc.

The H-Coal process concept was developed by Hydrocarbon Research, Inc. under sponsorship of the office of Coal Research. Today the work is sponsored by the Department of Energy and a private consortium composed of:

- Electric power Research Institute

- Ashland Synthetic Fuels, Inc.

- Conoco Coal Development Company

- Mobil oil Corporation

- Standard oil Company (Indiana)

- The Commonwealth of Kentucky.

One of the objectives of the H-Coal process is to design a pilot plant capable of converting 600 tons of coal per day into 2,000 barrels per day of low sulfur boiler fuel.

The specific operating conditions of the $\mathrm{H}$-Coal Process affect the type of fuel produced. The production of synthetic crude oil requires more hydrogen and there is lower yield of boiler fuel type of material. The separation of the solids, unconverted carbon and ash, from the liquid is accompanied by vacuum distillation. Low sulfur boiler fuel can be produced by lowering the temperature and pressure in the ebullatedbed reactor. 
EXHIBIT 2-1

Boiler Fuel product Yield and Composition

\begin{tabular}{|c|c|c|c|}
\hline r & $\mathrm{H}$-Coal & $\begin{array}{c}\text { Exxon: iDonor } \\
\text { Solvent }\end{array}$ & SPC-II \\
\hline Distillation Range ${ }^{O} \mathrm{~F}$ & $400-950$ & $700+$ & $350-900$ \\
\hline Yield (bbls/Ton Dry Coal) & 0.6 & 0.7 & 1.5 \\
\hline Specific Gravity & .968 & 1.1 & 0.99 \\
\hline Elemental Composition (wt \%) & & . & \\
\hline $\begin{array}{l}\text { Earbon } \\
\text { Hydrogen } \\
\text { Sulfur } \\
\text { Nitrogen }\end{array}$ & $\begin{array}{l}90 \\
7.6 \\
0.22 \\
1.0\end{array}$ & $\begin{array}{l}88.5 \\
6.3 \\
0.79 \\
1.1\end{array}$ & $\begin{array}{r}87.9 \\
8.1 \\
0.3 \\
1.0\end{array}$ \\
\hline Heating Value Btu/lb. & 17,700 & 16,500 & 17,600 \\
\hline
\end{tabular}

SOURCE: U.S. Department of Energy; Gulf Mineral Resources Company 
1. Currently, a 2.5 Ton/Day H-Coal Process Development Unit Is in Operation and a 600 Ton/Day Pilot Plant Is Under Construction Adjacent to the Ashland Oil, Inc. Refinery in Catlettsburg, Kentucky and Is scheduled To Commence Operations During the Last Quarter of 1979

The H-Coal process worked satisfactorily in the process development unit and during bench scale testing. The process demonstration unit demonstrated substained operations with many types of coal, including:

- $\quad$ Illinois No. 6
- Fyoming
- Five eastern coals
- Two lignites
- Two foreign coals

The H-Coal process operating in the syncrude mode produced fuel oil containing 0.5 percent sulfur. Testing of the boiler fuel produced from the H-Coal process showed that (1) the products are high in nitrogen, (2) the high nitrogen content of: the boiler fuel yield content may require modified combustion to meet the EPA new source performance standards, and (3) the H-Coal process boiler fuel is not miscible with petroleum-derived heavy oil. Additional testing will be required to establish the miscibility of $\mathrm{H}$-Coal boiler fuel with current commercial products since small scale tests conducted so far indicate that the coal-derived boiler fuel may not be miscible with No. 6 fuel oil.

2. Ashland Submitted a Proposal to the Department of Energy To Study a 20,000 Ton/Day Plant Capable of Processing High Sulfur Coal Into 50,000 Barrels/Day of Coal-Derived Liquids

Ashland is already planning the next phase of process development. This is indicative of recent reports that the HRI/Ashland consortium's interest in moving the $\mathrm{H}$-Coal process into a state of commercialization readiness as soon as possible. Representatives of Ashland have reported that a 20,000 ton/day plant could be easily configured to the boiler 
fuel mode or to the transportation fuel mode, depending on the economic outlook for each fuel; and the Government's fuel use policies which will be established.

(2) The Exxon Donor Solvent Process is a Non-Catalytic Hydrogenation Concept Developed by Exxon Research and Engineering Company

Crushed coal is liquefied in a noncatalytic tubular. reactor in the presence of molecular hydrogen and the hydrogen-donor solvent. The slurry leaving the liquefaction reactor is separated by distillation into gas, naptha, distillates, and a vacuum bottoms slurry; which is coked to produce additional liquids. The EDS

procese provides high yiclds of low sulfur liquids from bi.tuminous or subhituminous coals or lignites. When using Illinois bituminous coal, the product yield from the EDS process yields approximately 2.6 barrels of liquids per ton of coal. Product yield may be varied by varying the liquefaction conditions or by adjusting the solvent properties.

The major objectives of the EDS Program administered by the DOE are to develop the EDS process design basis necessary to liquefy a range of different coals in an environmentally acceptable manner, develop and demonstrate the necessary process technology to insure a reliable commercial design, and to conduct a product testing program to insure that marketable products can be produred.

1. Currently, a One Ton/Day EDS Process Development Unit Is in operation and a 250 l'on/Day Yilot plant. Has Reen nesigned and Is currently Under Construction Adjacent to Exxon's Baytown, Texas Refinery

The 250 ton/day pilot plant under construction is designed to produce 700 barrels of coal-derived liquids per day. The plant is being built under the sponsorship of DOE in conjunction with an industry consortium comprised of:

EPRI

- Carter Oil Company (Exxon subsidiary)

- Phillips Petroleum Company

- Atlantic Richfield Company

- Japan Coal Liquefaction Development Company

- Ruhrkohle, A.G. 
2. Exxon Has Reported That the Next Step Is the Development of a 25,000 Ton/Day Pioneer Plant

Under normal commercial development, the pioneer plant would probably not be constructed until the $250 \mathrm{~T} / \mathrm{D}$ pilot plant is fully tested and the economic environment offers assurance for commercial success.

(3) The SRC-II Process is Being Developed by Pittsburgh and Midway Coal Mining Company, a Subsidiary of Gulf Oil Corporation, Under the Sponsorship of DOE

The process converts high-sulfur, high ash coals to an essentially ash free low-sulfur fuel oil. Coal is pulverized and mixed with a coal-derived solvent in a slurry. The slurry is combined with hydrogen and is then pumped through a preheater and is then fed into a dissolver. Most of the coal is converted to a heavy oil by means of solvent extraction and solvent hydrogenation. Increased severity (higher pressure and temperature) of reaction conditions cause a major part of the coal to be converted to a liquid distillate product.

The major objectives of the SRC-II process research are to obtain technical and economic data from the pilot plant to validate scale-up to commercial production and to provide samples of products from the orocess for market development studies.

1. Currently, a 50-Ton/Day Pilot Plant in Ft. Lewis, Washington Is In Operation; and Product Test Burns Seem To Have Proven the Technological Acceptance of the Process

SRC-II boiler fuel was tested by Babcock and Wilcox Co. in Barkerton, ohio and KVB, Inc. in Tustin, California. The combustion performance was similar to No. 2 fuel oil except that $\mathrm{NO}_{\mathrm{x}}$ emissions were higher than No.2 fuel oil.

A 4,500 barrel batch of SRC-II boiler fuel was test burned in a tangentially fired boiler of the 74 th street Station of Consolidated Edison Co., New York. The test burn was judged to be very successful; and although the $\mathrm{NO}_{\mathrm{x}}$ emissions were greater than those from combustion of low-sulfur No. 6 fuel oil, the emissions were below the limits set by EPA for coal-derived fuels. Particulates and 
unburned hydrocarbons were less than those observed with the combustion of No. 6 fuel oil. There were no major operating problems associated with the combustion of SRC-II, boiler efficiencies obtained during the test were comparable to those recorded when No. 6 fuel oil was burned, and test results show that SRC-II boiler fuel may be low enough in viscosity to allow pipelining. With regard to this latter point, additional tests will need to be conducted to establish whether long-distance pipelining can take place.

2. Gulf Recently Submitted a Proposal to DOE for a 6,000 Ton/Day Coal Liquefaction Plant Capable of Producing 20,000 Barrels/Day of Petroleum Fquivalent Liquids

As reported in the media, Gulf's plan calls for the development of a full-scale coal liquefaction plant in Morgantown, West Virginia, scheduled to be in operation in the 1984-1985 time period.

2. THE OUTLOOK FOR THE MARKETABLITITY OF DIRECT COAL LIQUEFACTION PRODUCTS AS BOILEP FUEIS INDICATED ADDITIONAL TESTING WILL BE REQUIRED TO ASCERTAIN IIARKET ACCEPTANCE OF COAL LIQUIDS AS A COMMERC IALLY VIABLE ALTERNATIVE TO RESIDUAL FUEL OIL

Products from the three direct coal liquefaction processes have been tested with respect to their suitability as boiler fuels. Although the fuels appear to offer combustion characteristics similar to No. 6 residual fuel oil, additional tests will be required to ascertain complete market suitability. The outlook for each fuel is discussed.

(1) Additional Tests Will Be Needed To Determine Whether H-Coal Boiler Fuel Could Be a Replacement for No. 6 Fuel Oil

H-Coal liquids have been produced in relatively small quantities by bench-scale systems and process development units. A pilot plant capable of processing 600 tons/day of coal into 2,000 barrels of coalderived liquids should be in operation by the last quarter of 1979. Actual production from the pilot plant will depend upon the severity of the operating conditions. At a low severity operation mode, the 
primary product is a replacement for No. 6 oil. Exhibit 2-2 compares the $\mathrm{H}$-Coal boiler fuel with No. 6 residual fuel oil. As the exhibit indicates, the higher heating value of $\mathrm{H}$-Coal boiler fuel is somewhat less than that of No. 6 fuel oil; however, this is not expected to be a major market entry barrier. The most important marketability element will likely be the nitrogen content, which is approximately 60 percent greater than that of No. 6 fuel oil. Large-scale combustion tests of $\mathrm{H}$-Coal boiler fuel will be required to ascertain any major problems associated with $\mathrm{NO}_{\mathbf{x}}$ emissions.

Since there have been only small amounts of $\mathrm{H}$-Coal boiler fuel material produced for testing purposes, full-scale marketability studies have not yet been completed.

(2) Preliminary Tests Show That EDS Boiler Fuel Could $\mathrm{Be}$ a Replacement for No. 2 Middle Distillate Fuel or a No. 6 Residual Fuel oil; However, Additional Test Burns Are Required To Resolve Marketability Questions

Principal products incorporated in the EDS commercial plant design are LPG, naphtha, and low sulfur fuel oil. The LPG fraction is considered a finished product for sale to established markets. The naphtha could be an unfinished product anticipated to have maximum value as feedstock for downstream refinery or petrochemical plants. The boiler fuel oil would be suitable for direct sale to commercial markets in the 1985-1990 timeframe, depending on the continued development of the liquefaction process and satisfactory test burn results.

Physical and chemical analysis on two EDS boiler fuel coal liquefaction products produced from Illinois No. 6 coal are shown in Exhibit 2-3. The first product is the 400-1000\%F fuel oil product that is produced in the liquefaction phase of the EDS process. This boiler fuel product meets No. 4 fuel oil specifications. The second product is the total $400+0 F$ boiler fuel produced from the EDS process. This product is the yield from both the liquefaction and coking phase. This material would meet all No. 6 fuel oil specifications except sediment. Combustion tests will be required before market suitability can be completely established. The sediment content of the coker liquid from the existing small pilot plant is 2 to 3 percent by weight. Exxon 
EXHIBIT 2-2

Comparison of $\mathrm{H}$-Coal Boiler Fuel With No. 6 Fuel Oil

\begin{tabular}{|c|c|c|}
\hline Fuel Praperties & $\begin{array}{c}\text { H-Coal } \\
\text { Boiler Fuel }\end{array}$ & $\begin{array}{c}\text { No. } \\
\text { Fuei } \\
0 i 1\end{array}$ \\
\hline Higher heating value, Btu/lb. & $17, ? 00$ & 19,150 \\
\hline Gravity, API at $60^{\circ} \mathrm{F}$ & 14.7 & $10-18$ \\
\hline Viscosity, sUS at $100^{\circ} \mathrm{F}$ & 3.00 & 1,500 \\
\hline Analysis: & & \\
\hline $\begin{array}{l}\text { Hydrogen } \% \\
\text { Witrogen } \% \\
\text { julfur \% } \\
\text { Dxygen \% } \\
\text { Jarjon \% }\end{array}$ & $\begin{array}{c}7.6 \\
1.0 \\
0.22 \\
1.5 \\
90.0\end{array}$ & $\begin{array}{c}12.25 \\
0.24 \\
0.28 \\
0.6 \\
86.6\end{array}$ \\
\hline
\end{tabular}

SOURCE: U.S. Department of Energy 
EXHIBIT $2-3$

Physical and Chemical Analysis of $400-1,000^{\circ} \mathrm{F}$ and $400+^{\circ} \mathrm{F}$ EDS Fuel Oil Products From Illinois No. 6 Coal

\begin{tabular}{lc} 
Physical Properties & $\begin{array}{c}400-1000^{\circ} \mathrm{F} \\
\text { Liquefaction } \\
\text { Product }\end{array}$ \\
\hline Gravity, Specific & 1,040 \\
Flash, ${ }^{\circ}$ & 198 \\
Pour Point, ${ }^{\circ}$ & 20 \\
Viscosity $0100^{\circ} \mathrm{F}$, SSU & 102 \\
viscosity e $122^{\circ} \mathrm{F}$, SSF & --- \\
Sediment, wt.8 & 0.05
\end{tabular}

$\begin{array}{cc}\begin{array}{c}\text { ASTM \#4 } \\ \text { Specifications }\end{array} & \begin{array}{c}400{ }^{\circ} \mathrm{F}^{+} \text {Product } \\ \text { Liquefaction } \\ + \text { Coking }\end{array} \\ {.} } & 1,085 \\ 20 \mathrm{Max} . & 40 \\ 45 \div 125 & -- \\ -5 \mathrm{Max} . & 158 \\ & \begin{array}{l}\text { (Tests cux- } \\ \text { rently being } \\ \text { conducted) }\end{array}\end{array}$

ASTM \#6 Specifications

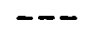

140 Min.

60 Max.

$40-300$

.5 Max.

rently being

. Max.

\section{Chemical Analysis}

$\begin{array}{lc}\text { Carbon } & 88.0 \\ \text { llydrogen } & 8.4 \\ \text { Sulfur } & 0.6 \\ \text { Oxygen } & 2.3 \\ \text { Nitrogen } & \frac{0.7}{1.00 .0}\end{array}$

87.9

7.0

0.8

(legal)

3.2

$\frac{1.1}{100.0}$

SOURCE: Exxon Research and Engineering Company 
advises that this may not be typical of commercial coke boiler fuel products and has studies in progress to determine the cost of removing the sediment.

Exxon's laboratory tests indicated that the $400^{\circ}-$ $1,000^{\circ} \mathrm{F}$ boiler fuel produced from Illinois No. 6 coal was not miscible with several commercial petroleum. heavy fuel oils. Exxon performed hydrotreatment testing of the material and determined that hydrotreating the boiler fuel could make it compatible with traditional petroleum fuel oils. Exxon has developed an experimental additive that was found effective in making coal-derived liquid boiler fuels compatible with petroleum fuel oils. The additive would facilitate the changeover from petroleum boiler fuel to coal-derived liquids boiler fuels. The current EDS commercialization plan calls for EDS boiler fuels to be handled and burned in segregated or dedicated facilities to avoid compatibility problems with petroleum fules. Exxon plans additional tests to resolve the miscibility question.

EDS boiler fuel (blend of solvent and vacuum gas oil) from Illinois No. $6\left(400^{\circ}-1,000^{\circ} \mathrm{F}\right.$ liquid) was test burned in a 50 horsepower industrial pass boiler. The results of the test burn indicated that the $400^{\circ}-1,000^{\circ} \mathrm{F}$ coal liquid burned with less smoke than a 2.2 percent sulfur No. 6 residual fuel oil. The coal Iiquid burned with less particulates than a reference No. 6 residual fuel oil and the particulate matter was below the EPA New suurce ferformance standard (NSPS).

The particulate and smoke data infer that the $400^{\circ}-1,000^{\circ} \mathrm{F}$ EDS liquid product produced from Illinois No. 6 coal could be operable in dedicated existing utility and industrial boilers.

SRC-II Boiler Fuel was Tested in a Utility Boiler; aná Although It Appeared To Be Technically Compatible With Residual Oil, Additional Tests Will Be Needed To Establish Commercial Viability

A combustion demonstration test utilizing distillate fuel oil from the SRC-II process was conducted on a utility boiler at the 74 th street Generating station of the Consolidated Edison Company of New York. Approximately 4,500 barrels of SRC-II boiler fuel were used in the test evaluation. To provide a comparison between 
characteristics for SRC-II fuel oil and typical utility fuel oils, data were also obtained with the No. 6 fuel oil currently used by Consolidated Edison. The SRC-II fuel oil tested was low in sulfur ( 0.22 percent) and ash $(0.02$ percent). The nitrogen content was relatively high ( 1.0 percent). The major finding of the test program was that boiler thermal efficiency levels with SRC-II were comparable to No. 6 residual fuel.

Although there were no major operational problems encountered during the test, the combustion of SRC-II fuel oil resulted in nitrogen oxide emissions levels approximately 70 percent greater than those for No. 6 residual fuel oil. Nitrogen oxide reductions were achievable, however, through combustion modifications. Nitrogen oxide reductions achievable were on the order of 33 percent for both SRC-II and No. 6 residual fuel oils. The test burn also indicated that particulate matter emissions were lower for the SRC-II fuel oil than for the No. 6 residual oil.

The results of the Consolidated Edison test indicate SRC-II boiler fuel may be technically compatible with residual fuel oil. However, representatives of Consolidated Edison indicated that the test was carried out under test conditions and as such, additional larger scale tests over a longer duration will need to be conducted to establish SRC-II as a commercially viable alternative to residual fuel oil.

A test of SRC-II at the Alliance Research Center of Babcock and Wilcox Company indicated that SRC-II combustion performance was similar to No. 2 and No. 5 fuel oils, and that no particular storage, handling, or emissions problems (except for high $\mathrm{NO}_{\mathrm{x}}$ ) should be expected when SRC-II is used in conventional combustion equipment operated in conventional firing modes. Exhibit 2-4 compares the properties of SRC-II, No. 2 fuel, and No. 5 fuel oil that were identified during the Babcock and Wilcox test. It should be recognized, however, that both this test and the Consolidated Edison test were short term in nature; and consequently, long-term storage and handling characteristics could not be evaluated.

The Babcock and wilcox test included a comparison of SRC-II handling characteristics with No. 2 and No. 5 fuel oils, and it was found that the SRC-II fuel oil was totatly miscible with petroleum fuel oils. Additional analyses indicated that the $200^{\circ} \mathrm{F}$ flash point of SRC-II would be sufficiently high to allow storage in tankage designed for No. 6 fuel. The low pour 
EXHIBIT 2-4

Physical Handling Properties of SRC-II,

No. 2 Fuel Oil, and No. 5 Fuel Oil

\begin{tabular}{|c|c|c|c|}
\hline & SRC-II & No. 2 Fuel $0 i 1$ & No. 5 Fuel $0 i 1$ \\
\hline Density & & & . \\
\hline API $@ 77^{\circ} \mathrm{F}$ & 12.4 & 40.3 & $16: 0$ \\
\hline API $060^{\circ} \mathrm{F}$ & $11: 5$ & $39.0^{\circ}$ & 15.1 \\
\hline S.G. O $67^{\circ} \mathrm{F}$ & 0.9895 & 0.8299 & 0.9652 \\
\hline $\begin{array}{l}\text { Viscosity - Saybolt } \\
\text { Universal Seconds }\end{array}$ & & & \\
\hline $077^{\circ} \mathrm{F}$ & - & 36.3 & - \\
\hline (a) $80^{\circ} \mathrm{F}$ & 47.7 & - & - \\
\hline (e) $122^{\circ} \mathrm{F}$ & 37.0 & 32.4 & 267 \\
\hline (d) $145^{\circ} \mathrm{F}$ & 34.4 & 32.0 & 143 \\
\hline (d) $174^{\circ} \mathrm{F}$ & - & - & 91 \\
\hline (a) $204^{\circ} \mathrm{F}$ & - & - & 67.2 \\
\hline Pour Point, ${ }^{{ }} \mathrm{F}$ & Below $-35^{\circ}$ & $-20^{0}$ & Zero ${ }^{0}$ \\
\hline $\begin{array}{l}\text { Sediment by Toluene } \\
\text { Extraction, \% }\end{array}$ & 0.05 & None & 0.10 \\
\hline $\begin{array}{l}\text { Sediment and water } \\
\text { (ASTM D96-73) }\end{array}$ & 1.0 & None & 1.9 \\
\hline Miscibility & & . & ${ }^{\circ}$ \\
\hline$\%$ SRC in & - & Totally Miscible & Totally Miscible \\
\hline$\%$ No. 2 in & - & - & Totally Miscible \\
\hline $\begin{array}{l}\% \text { No. } 2 \text { and No. } 5 \\
\text { Mixture in }\end{array}$ & $\begin{array}{l}\text { Totally } \\
\text { Miscible }\end{array}$ & - & - \\
\hline $\begin{array}{l}\text { Copper Corrosion } \\
\text { (ASTM DI30-75) }\end{array}$ & $\begin{array}{l}\text { Moderate, } 2 b- \\
\text { Color: Lavender }\end{array}$ & $\begin{array}{l}\text { Slight, 1b- } \\
\text { Color: Dark Orange }\end{array}$ & $\begin{array}{c}\text { Moderate, } 2 c- \\
\text { Color: Multicolored }\end{array}$ \\
\hline $\begin{array}{l}\text { Surface Tensign, } \\
\text { dynes/cm } 022^{8} \mathrm{C}\end{array}$ & - 34.1 & 29.9 & 34.5 \\
\hline $\begin{array}{l}\text { Oxidation Stability } \\
\text { mg/100 mi } \\
\text { (ASTM D2274) }\end{array}$ & 4.0 & 10.7 & - \\
\hline
\end{tabular}

SOURCE: Characterization and Combustion of SRC-II Fuel 0il, The Babcock \& Wilcox Company, June 1979. 
point (below -350F) concomitant with low viscosity would render tank heaters unnecessary except in the . coldest climates. As was the case in the consolidated Edison test, pumping from storage was not recognized as being a problem. It was also found that water and sediment content are no more severe for SRC-II than for No. 6 fuel oil. The main conclusions regarding SRC-II handling are that it can be readily pumped from storage to the boiler, and heat tracing of lines should be unnecessary. SRC-II does not appear to be any more corrosive to metals than petroleum oils, and positive displacement pumps designed specifically for low viscosity fuel oils should be installed in the internal plant transfer system.

A principal observation from the Babcock and Wilcox test regarding. combustion characteristics affecting the use of SRC-II as a replacement for No. 6 fuel oil is that EPA's New Source Performance standard of 0.5 pound $\mathrm{NO}_{\mathrm{x}} / \mathrm{million} \mathrm{Btu}$ could be met by the use of staged combustion and by matching burner and atomizer designs.

3. THERE WERE VARIOUS FACTORS IDENTIFIED IN THE INDUSTRIAL ASSESSHENT THAT REQUIRE ADDITIONAL RESEARCH

The chemical and physical properties of the coal liquefaction boiler fuels addressed in this study indicate additional research should be conducted to ascertain market suitability of these fuels. Some of the fuels have been more fully tested than others, such as the SRC-II boiler fuel product. However, industrial and utility representatives advise that the fuels from all three process should be developed and fully tested so that a complete comparison of all combustion characteristics and handling requirements can be made.

(1) Industrial sector Representatives Indicate That the Chemical Composition and Physical Properties of Direct Coal Liquefaction Products May Require Possible Handling and Combustion Modifications Before Use in Boilers

Coal-derived liquids are more aromatic than petroleum-derived fuel oil and may require special storage requirements. In addition, some coal-derived boiler fuels contain residual fractions high in asphaltenes and are incompatible when blended with petroleum derived fuel oils. Preliminary indications are that the H-Coal process and the EDS process yield boiler 
fuels that are not miscible with traditional boiler fuels without special treatment or additives. Additional testing should be conducted to determine whether the miscibility problems can be overcome for systems needing dual fuel capabilities or which must use fuel blends.

The third major factor is the high nitrogen content of the coal derived liquids. Most combustion tests conducted to date indicate that the NOx emissions can be controlled within EPA's New Source Performance Standards. Most industrial sector representatives indicate, however, that they would like to see additional tests conducted on coal-derived liquids to identify any additional combustion controls that could be employed and that have not yet been identified.

With regard to continued testing efforts, additional large scale boiler tests using SRC-II fuel oil are being planned for 1980. Some small scale tests with SRC-II, H-Coal and EDS liquid fuels have been performed on home heating furnaces and on industrial boilers and larger scale boiler tests using fuels from the $\mathrm{H}-\mathrm{Coal}$ and EDS liquefaction processes are being planned for 1980. The consensus of opinion from the industrial sector is that additional test burns need to be conducted on fuels from all three liquefaction processes to fully substantiate their combustion suitability.

Certain Direct Coal Liquefaction Boiler Fuel Specifications Have Significant larketing Implications

As discussed earlier, there are indications that some of the coal derived boiler fuels may not be miscible when blended with petroleum derived fuel oils. There is not a large body of data on the question of miscibility of coal derived boiler fuels with conventional fuel oils, however, the marketing implications of this potential problem can be identified:

Separate storage facilities would be required at the. consumption point

Segregated transportation modes would be necessary 
- Segregated piping at consumption points ( would be necessary

- Batch utilization at the consumption point would be required

- Dedicated boiler systems at consumption points would need to be installed.

The specific gravity of each of the coal 1iquefaction boiler fuels could be greater than 1 with the use of different coals and with process conditions under different severity levels. A spill from a water-borne vessel could sink to the bottom of the river or ocean on which the material is being transported and a large spill could have a signficant cleanup problem. Additional research is needed in this area.

The low API gravity of each coal liquefaction fuel oil product does not by itself pose a logistical barrier to the utilization of pipeline transportation. Additional factors affecting the transportation mode selected for coal liquids marketing include viscosity, miscibility, and product segregation. Tests on coal liquids have been conducted in these areas, but transportation companies interviewed do not perceive the tests conducted to date as being conclusive. Additional tests will be required to completely answer transportation mode selection criteria. Tests conducted to date on SRC-II material indicate favorable pipeline shipment adaptability. Additional tests on SRC-II material die planned during 1980.

There is insufficient data available to adequately evaluatellong distance pipelining of coal-derived builer fuels; and consequently, additional research needs to be conducted in this area. 
(3) Long-Term Combustion Affects and Maintenance Requirements can not be Adequately Determined Because There are no Commercial Liquefaction Plants in Operation and the Data Base Needed to Adequately Evaluate Commercial Acceptability is Very Limited

Limited combustion tests have been performed on coal liquefaction boiler fuels, and as such, longterm combustion impacts can not be evaluated. Information regarding maintenance requirements is not available due to the limited testing conducted to date. Additional test burns need to be conducted to establish coal liquids' long-term effects on boilers and to develop maintenance guidelines. 
CHAPTER 3

POTENTIAL MARKETS FOR COAL LIQUEFACTION BOILER FUELS 
CHAPTER 3

POTENTIAL MARKETS FOR COAL LIQUEFACTION BOILER FUELS

This chapter presents an analysis of the potential market for coal liquefaction products as boiler fuels. National and regional fuel consumption forecasts for the utility and industrial markets are presented in this chapter. Booz, Allen \& Hamilton utilized data primarily from the Energy Information Administration (EIA) at DOE to develop the forecasts. Informed judgments based on other data available to Booz, Allen were also incorporated into the consumption forecasts. The MFBI-DOE data base was utilized in this study to provide consistency to the analytical effort. It is recognized that other data bases exist which forecast boiler fuel consumption in the utility and industrial sectors, and each data base may reflect a somewhat different potential market for coal-derived liquids.

The analysis will concentrate on the near-term market for coal liquids (1980-1990 timeframe). President Carter's Administration has recently proposed that the Nation's electric utilities reduce their fuel oil consumption (residual and distillate) by 50 percent during the period 19801990. This would imply a substantial reduction in the DOE forecasted residual fuel oil market in 1990 (1.2 million barrels/day by DOE versus $0.8 \mathrm{million}$ barrels/day by President Carter's Administration.) A qualitative discussion of the President's recent proposals as they pertain to utility and industrial demand for fuel oil will be included; however, no attempt has been made to alter the DOE forecasts to reflect this most recent event.

A detailed presentation of the regional and national forecasts of utility and industrial fuel consumption and data concerning utility capacity expansion plans, oil and gas steam plant retirements, and projected new oil and gas steam plants appears in Appendix $A$.

1. A DECLINE IN RESIDUAL OIL, DISTILLATE OIL, AND NATURAL GAS CONSUMPTION IN THE ELECTRIC UTILITY INDUSTRY IS FORECASTED OVER THE NEXT TEN YEARS

The utility industry utilizes a mix of fuels to generate the Nation's electricity. In 1978, residual oil, distillate oil, and natural gas fuels accounted for approximately 35 percent of primary energy source inputs to U.S. electricity generation. Residual and distillate fuel consumption was $1.7 \mathrm{million}$ bbl/day in 1978--almost 20 percent of utility fuel consumption. 
In 1978, residual oil consumption alone was 1.6 million bbl/day. The substitution of coal liquids for residual fuel oil represents the largest near-term utility market for coal liquids. Similarly, natural gas consumption was 1.4 million bbl/day of residual oil equivalent-clearly a large potential market for coal liquids.

By 1990, however, residual oil, distillate oil, and natural gas consumption is forecasted to decline. As illus-trated in Exhibit 3-1, residual oil is forecasted to decline to 1.2 million bbls/day and natural gas consumption to decline to $250,000 \mathrm{bbl} /$ day of residual oil equivalent. Although the utility industry will still be large enough to support a market for coal liquids, the decline in fuel oil and natural gas consumption by 1990 may represent a market barrier to coal liquid development as a boiler fuel.

Several factors are responsible for the decline in forecasted fuel oil and natural gas consumption by 1990:

Increased utilization of coal and nuclear fuels

Planned and accelerated retirements of existing oil and gas plants

- Conversion of existing oil and gas plants to coal and other alternate fuels

- Lower utilization factors of existing oil and gas plants.

(1) Coal and Nuclear Capacity Are Forecasted to Increase In Base Load and Intermediate Applications But the Impact of Three Mile Island, and Environmental Leqislation Pertaining to Coal May Slow Coal and Nuclear Near-Term Growth

Coal and nuclear fuels are forecasted to grow from 6 million barrels/day of residual oil equivalent in 1978 to approximately $14 \mathrm{million}$ barrels/day in 1990. Of the 308 gigawatts of new base load and intermediate capacity forecasted to come on-line by 1990, coal and nuclear account for 93 percent (287 gigawatts) while residual oil accounts for less than 2 percent of new capacity (5 gigawatts). A complete forecast of capacity additions for the utility industry for 1990 is summarized in Exhibit 32 .

In the wake of the recent nuclear reactor accident at Three Mile Island, it is difficult to forecast the prospects of nuclear-generated electricity in the near 
EXHIBIT 3-1

National Forecast of Primary Fuel Consumption by Electric Utilities 19.78-1990

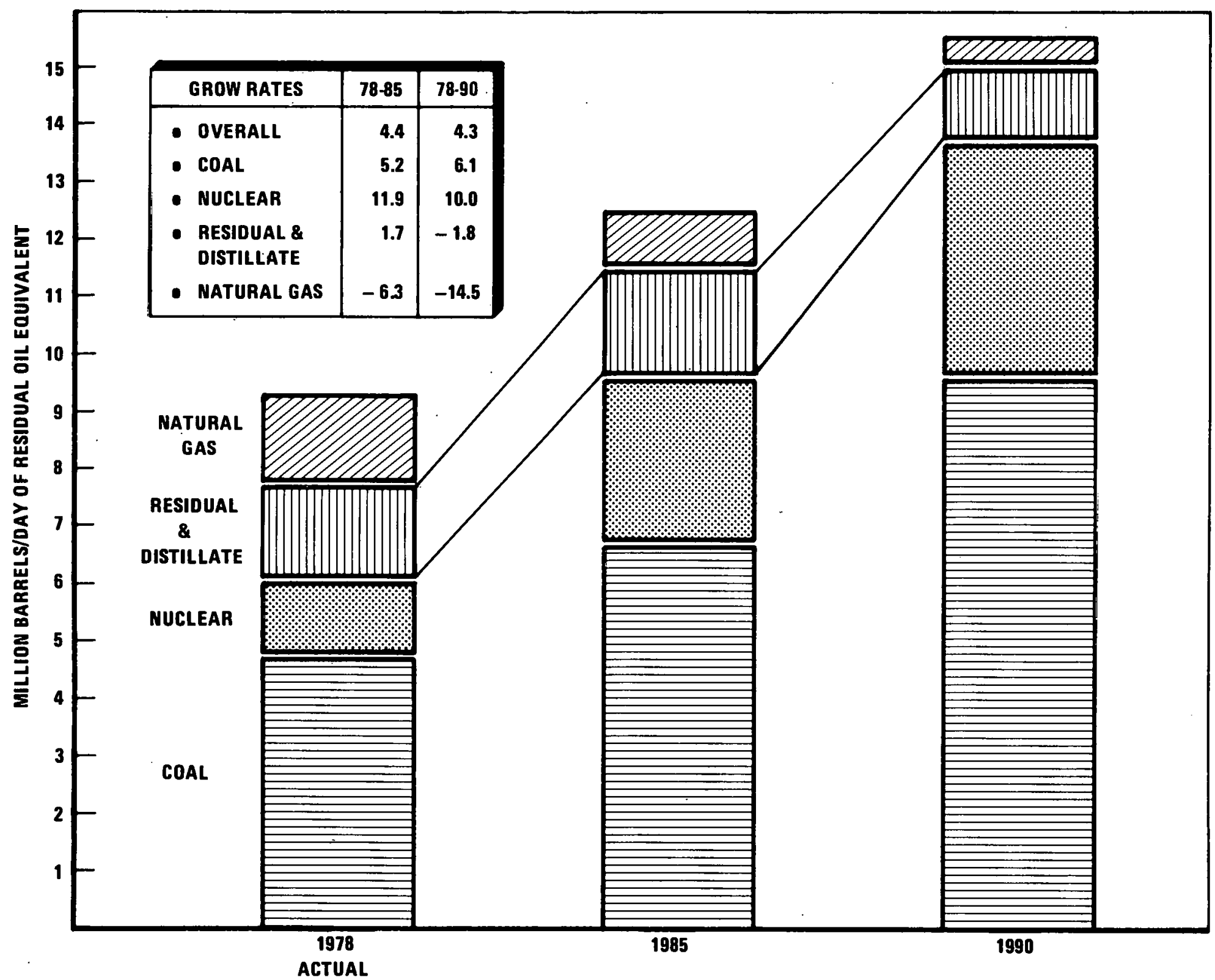

SOURCE: Energy Information Administration, DOE and Booz, Allen \& Hamilton Inc. 
EXHIBIT $3-2$

National Electricity Generation Forecast 1990

\begin{tabular}{|c|c|c|c|c|c|c|c|c|}
\hline \multirow{3}{*}{ Resource } & \multicolumn{8}{|c|}{ Capacity in Gigawatts } \\
\hline & \multicolumn{2}{|c|}{ Base } & \multicolumn{2}{|c|}{ Intermediate } & \multicolumn{2}{|c|}{ Peak } & \multicolumn{2}{|c|}{ Total } \\
\hline & Existing & New & Existing & New & Existing & New & Existing & New \\
\hline Nuclear & 46.0 & 99.9 & - & - & - & - & 46.0 & 99.9 \\
\hline Coal With Scrubbers & 10.8 & 140.5 & 3.5 & 1.0 & - & - & 14.3 & 141.5 \\
\hline Coal Without Scrubbers & 176.7 & 46.1 & 13.5 & - & 4.9 & - & 195.1 & 46.1 \\
\hline Distillate Turbines & - & - & - & - & 3.3 & 14.3 & 3.3 & 14.3 \\
\hline Combined Cycle-Distillate & 1.7 & 7.0 & 0.8 & - & 0.6 & 0.1 & 3.1 & 4.1 \\
\hline Gas Turbines & - & - & - & - & 4.3 & - & 4.3 & - \\
\hline Gas Steam & - & - & 3.6 & - & 12.9 & - & 16.5 & - \\
\hline Resijual (0i1-Steam) & 28.3 & 3.6 & 5.8 & 1.7 & 23.6 & 2.6 & 57.7 & 7.9 \\
\hline Hydro & 23.5 & 4.6 & 17.1 & 1.8 & 22.8 & 0.3 & 63.5 & 6.7 \\
\hline Pumped Storage & - & - & - & - & 9.7 & 18.0 & 9.7 & 18.0 \\
\hline $\begin{array}{l}\text { Solar (including hydro- } \\
\text { thermal, solar thermal, } \\
\text { photovoltaics, wind, } \\
\text { biomass, and ocean } \\
\text { thermal }\end{array}$ & - & $\bar{j} .1$ & $-\cdot$ & - & - & - & - & 5.1 \\
\hline Total & 287.1 & 303.8 & 44.3 & 4.5 & 82.1 & 35.3 & 413.5 & 343.6 \\
\hline
\end{tabular}

Source: 1990 forecast data were obtained from supporting computer runs to the Annual Report to Congress, 1979, supplied by The Energy Information Administration, DOE 
term. The Three Mile Island occurrence has substantially eroded public and private optimism regarding the future use of commercial nuclear power systems in the U.S.

Already the Three Mile Island incident has affected forecasts of nuclear power's share of the U.S. electric generation market. As recently as March 1979, DOE estimated that nuclear-generated electricity would grow from its present share of 14 percent of the market to 28 percent by 1990. Recently, however, it has been estimated by the utility industry that nuclear power will account for only 20 percent of total power generation by 1990. Some experts are arguing that even this modest growth prediction, approximately half the rate predicted by DOE earlier this year, may be too optimistic.

The remaining power generation capacity previously projected for nuclear is now expected to be provided by coal. Such an immediate increase in coal utilization, however, would be a formidable undertaking for the U.S. coal industry. Regulations stemming from numerous laws may restrict the supply and production of coal. These laws include:

- The Surface Mining Control and Reclamation Act of 1977, which affects the cost of both underground and surface mining, and restricts development of certain coal reserves

- The Federal Coal Leasing Act Amendments of 1976, which affect development of western publicly owned coal lands, and require developers to relinquish their leases by July 1986 if developers have not yet initiated substantial mining operations

- The Federal Coal Mine Health and Safety Act of 1969 , which has affected coal productioni costs and mining productivity.

In addition to the laws and regulations affecting coal mining and production, there are laws affecting the consumption of coal by industries and utilities. The most important legislation affecting coal consumption and the law which will have the greatest negative impact on coal utilization is the Clean Air Act and its 1977 amendments. To implement this legislation concerning emissions from 
coal-burning facilities, the Environmental Protection Agency (EPA) has promulgated New Source Performance Standards (NSPS). The most stringent emission requirements will apply to power plants built after 1978 by requiring costly scrubbing systems to be installed to reduce sulfur emissions.

If both coal and nuclear power generation capacity growth are limited in the near term, then residual oil and gas steam plants may be expected to provide the difference. For example, the DOE forecast of $1.2 \mathrm{mil}-$ lion bbl/day of residual oil consumption will be low if coal and nuclear capacity growth is restricted.

Planned and Accelerated Oil and Gas Retirements and Conversions of Existing Oil and Gas Plants to Coal Account for the Forecasted Decline in Oil and Gas Consumption by 1990

In 1978, there was a total of 106 GW of oil-fired steam plants and $66 \mathrm{GW}$ of gas steam plants in operation. As shown in Exhibit 3-3, approximately 40 percent of the oil- and gas-fired steam plant capacity are under ten years old, and 75 percent were built after 1958 . Most of the plants under 20 years old are operating in base and intermediate loads and are candidates for conversion to coal. The Power Plant and Industrial Fuel Use Act of 1978 established guidelines and regulations pertaining to conversions to coal. The success of the Fuel Use Act to convert existing oil and gas steam plants to coal, for the most part, will influence the market size for coal liquids.

In addition to coal conversions, many older oil and gas steam plants ( $>20$ years.) will be retired during the next ten years. DOE has encouraged the utility industry to accelerate oil and gas retirements. Many utilities are also utilizing existing plants at lower capacity factors (switching from base to intermediate load) which will also reduce residual oil consumption.

(3) The Availability of Natural Gas in the Near Term for Utility Consumption Will Influence the Market for Residual Oil and Substitute Coal Liquids

In 1976, DOE encouraged utilities to burn residual and middle distillate fuel oil to conserve natural gas which was in short supply. Since legislation on 
EXHIBIT $3-3$

Total Market Size of Existing Oil-Fired

and Gas Steam Plants

1978

\begin{tabular}{|c|c|c|c|c|c|c|}
\hline Plant & \multicolumn{2}{|c|}{ Oil } & \multicolumn{2}{c|}{ Gas } & \multicolumn{2}{c|}{ Total } \\
\cline { 2 - 7 } Age & No & MW & No & MW & .No & MW \\
\hline $0-10$ & 100 & 40,000 & 117 & 31,000 & 217 & 71,000 \\
$10-20$ & 225 & 36,000 & 168 & 22,000 & 393 & 58,000 \\
$>20$ & 538 & 30,000 & 398 & 13,000 & 936 & 43,000 \\
\hline Total & 863 & 106,000 & 683 & 66,000 & 1,546 & 172,000 \\
\hline
\end{tabular}

Note: Includes all plant sizes.

SOURCE: DOE Power Plant Listing, July 1978。 
deregulation of natural gas was passed last year, gas supplies are now available for utility consumption. DOE has recently announced fuel switching plans which would allow 21 'utilities in 14 states to burn natural gas instead of middle distillate fuel oil. DOE has recently forecasted that the switch to natural gas would reduce the need for $4.7 \mathrm{million}$ bbl/year of oil normally used by these generating stations.

Most energy experts agree that, in the long term, utilities should be encouraged to switch from natural gas to alternate fuels such as coal. In the near term, however, the availability of natural gas supplies has led to fuel switching plans by DOE to reduce fuel oil consumption. The availability of natural gas in the near term for utility consumption, therefore, will influence the market for fuel oil and substitute coal liquids.

2. THE ADMINISTRATION HAS RECENTLY PROPOSED THAT THE NATION'S ELECTRIC UTILITIES REDUCE THEIR FUEL OIL CONSUMPTION BY 50. PERCENT DURING THE PERIOD 1980-1990

The Nation's utilities currently consume 1.6 million barrels/day of fuel oil in their boilers for generation of electric power. The President is proposing legislation to Congress which would require utilities to reduce current usage by 50 percent by 1990. This would translate to a reduction in fuel oil consumption from current levels of 1.6 million barrels/day to 800,000 barrels/day by 1990 . Incentives in the form of grants and/or loan guarantees would be provided to encourage utilities to invest in new non-oil-fired generators, thereby retiring existing oilfired plants earlier than would otherwise occur. This initiative covers oil-burning plants which are capable of burning coal as well as those which are not.

Grants and loan guarantees of $\$ 5$ billion over the period 1980-1990 will be made available to assist in financing this switch away from oil to sources such as coal, nuclear, or where possible, solar and conservation. 
(1) A Market Reduction in Fuel Oil Consumption of 50 Percent by 1990 Would Pose a Market Barrier to Coal Liquids Development as a Boiler Fuel by Private Industry

Interviews with utility industry representatives concerning the Administration's oil consumption goals indicate that if such a reduction were achievable, it would reduce the national need to develop a coal liquids industry to supply boiler fuels. For example, if the 1990 target of $800,000 \mathrm{bbls} /$ day for fuel oil consumption by utilities were again reduced by 50 percent by 2000, fuel oil consumption would be $400,000 \mathrm{bbl} /$ day. Assuming that a coal liquids industry would be available for commercial production by $1990,400,000$ $\mathrm{bbl/day}$ would support, at most, eight 50,000 bbl/day coal liquids plants, with each yielding only boiler fuels.

(2) Many Utilities Will Encounter Difficulties in Switching From Oil to such Sources as Coal, Thereby Increasing the Attractiveness of Coal Liquids in Certain Utility Regions

Many oil-fired utilities, particularly in the Northeast, Atlantic, and West Coast areas will be limited in their ability to switch from oil to coal because of environmental constraints and economic considerations. Under the President's program, "tickets" or rights to burn oil will be distributed to utilities. No utility may use oil in excess of the amount of the tickets which it holds. These tickets may be traded between utilities according to their varying abilities to substitute other fuels. These transferable rights to burn oil will permit the utilities themselves to determine where to make replacements for current oilfired capacity. For example, utilities in areas where environmental constraints make replacement uneconomic (such as the Northeast) would be permitted to buy tickets from other regions which could convert to coal. It is expected that these tickets will have a maximum value to any utility company equivalent to the cost. of conversion or replacement of oil-fired capacity versus continued use of oil.

If coal liquids as a boiler fuel were available in significant quantities before 1990, then utilities in areas which could not comply with the President's program (i.e., utilities unable to convert to coal) 
would be willing to pay a price for coal liquids equivalent to the value to tickets. This would act as an incentive to develop commercial coal liquid plants to supply boiler fuels to various regions of the country.

3. FIVE DOE UTILITY REGIONS HAVING RESIDUAL OIL CONSUMPTION ABOVE 200,000 BARRELS/DAY ARE CANDIDATE MARKETS FOR COAL LIQUIDS IN THE NEAR TERM

A summary of regional data on residual oil inputs to U.S. electrical generation is shown in Exhibit 3-4. Five DOE utility regions have been selected as probable regional markets for coal liquids as boiler fuel based on market size. The five regions and their 1978 residual fuel oil consumption is graphically shown as Exhibit 3-5.

These five regions account for $1.35 \mathrm{million}$ bbl/day (approximately 85 percent of the national residual fuel oil consumption). The remaining five regions-Midwest, Southwest, Central, Northwest, and North Central-account for $0.26 \mathrm{mil}-$ lion bbl/day (approximately 15 percent of the national residual fuel oil consumption). Although the Midwest and Southwest could provide a potential market for coal liquids (w.ith residual oil consumption of 115,000 and $125,000 \mathrm{bbl} / \mathrm{day}$, respectively), these areas did not appear to be likely "first" markets for coal liquids based on several interviews with representatives in each region.

(1) The New England and New York/New Jersey Area Represents the Largest Potential Market Area for Coal Liquids as Boiler Fuels

The New England and New York/New Jersey area represents the largest potential market area for coal liquids with a residual oil consumption of $513,000 \mathrm{bbl} /$ day in 1978. By 1990, the region is forecast to require 263,000 bbl/day-still a large market area for coal liquids.

The New England and New York/New Jersey area is a particularly attractive market for coal liquids because utilities in this area will be restricted from switching away from oil to sources such as coal, based on regional environmental constraints and uneconomic capacity replacements for coal.

Interviews with utility industry representatives in the New England and New York/New Jersey area concerning the potential use of coal liquids as boiler 
EXHIBIT 3-4

Summary of Regional Data of Residual Oil Inputs

to U.S. Electric Generation

\begin{tabular}{|c|c|c|c|c|c|c|c|c|c|c|c|}
\hline \multirow{2}{*}{ Year } & \multicolumn{11}{|c|}{ Regional Utility Consumption in Thousand Barrels/Day } \\
\hline & New Eng & $\mathrm{NY} / \mathrm{NJ}$ & Mid-Atl & S. Atl. & Midwest & S. West & Central & N. Central & West & N. West & Total \\
\hline 1978 & 203 & 310 & 233 & 286 & 115 & 125 & 17 & 3 & 316 & - & 1,608 \\
\hline $1990 *$ & 191 & 72 & 116 & 109 & 98 & 8 & 11 & - & 596 & - & 1,200 \\
\hline
\end{tabular}

* 1990 forecast data were obtainec from supporting computer runs to Analysis Report, Energy Supply \& Demand in the Midterm: 1985, 1990, 1995, F.pril 1979, DOE/EIA-0102/52. 
EXHIBIT 3-5

Regional Residual Fuel Oil Consumption 1978

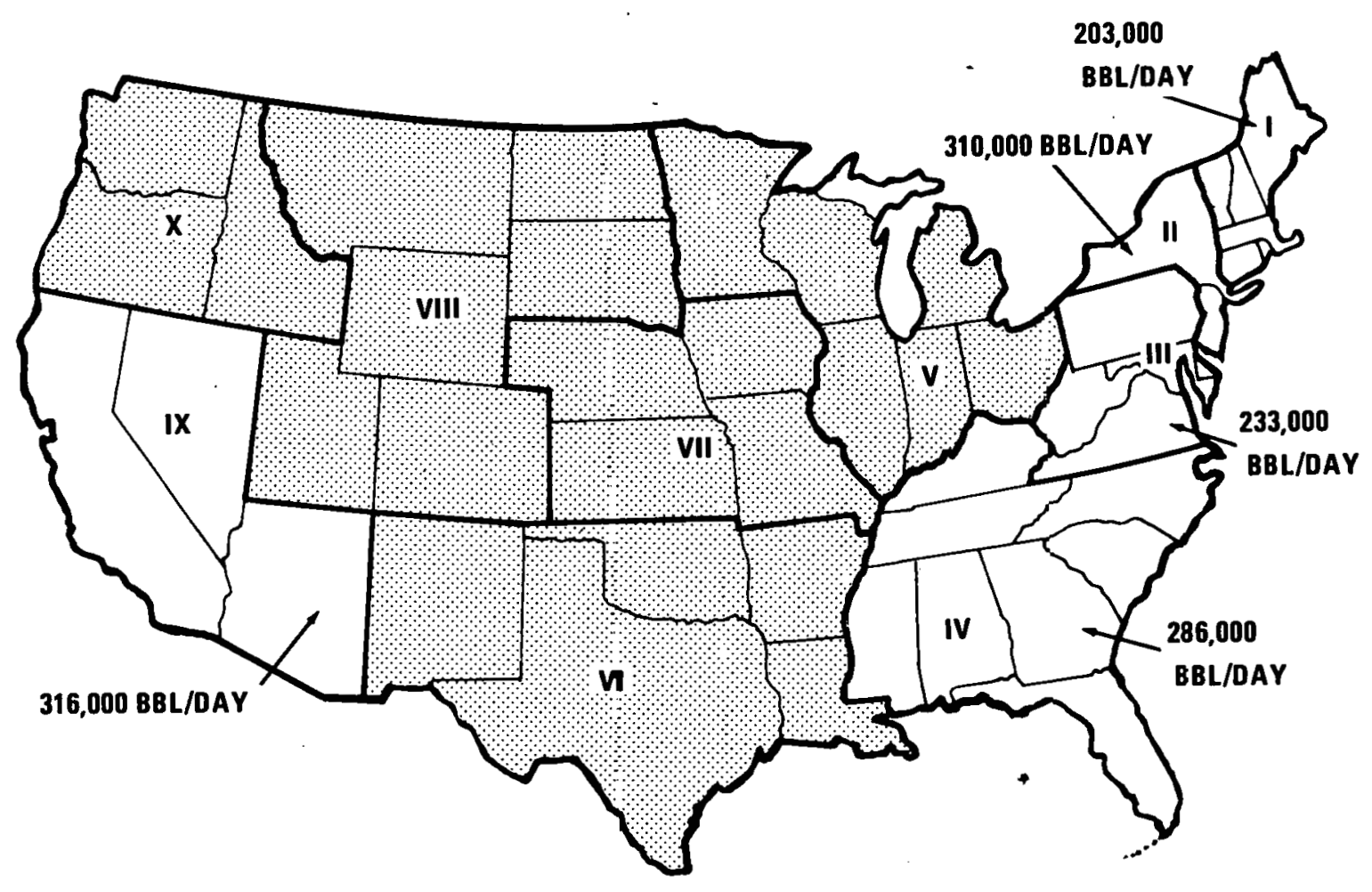

NOTES: (1) SHADED AREAS REPRESENT FEGIONS WHICH CONSUMED LESS THAN 200,00D BBL/DAY OF RESIDUAL FUEL OIL IN 1978

(2) NON-SHADED REGIONS CONSUMED MORE THAN 200,000 BBL/DAY IN 1978 REPRESENTING APPROXIMATELY 85\% OF THE RESIDUAL OIL MARKET OF UTILITIES 
fuels indicated strong interest in the successful and economic development of commercial coal liquids as boiler fuels.

1. Coal-Derived Liquids May Be a Commercially Viable Alternative Fuel by the late 1980s in the Northeast, particularly for Existing Oil-Fired Utility Units; These Are the Findings of a study Recently completed by the Northeast Coal Utilization Program (NECUP)

Because of Government efforts to reduce utility oil consumption-plus the uncertainty of both the cost and supply of imported ofl-Boston Edison, Long Island Lighting Company, New England Gas and Electric Association, New England Power' Service Company, Northeast Utilities Service Company, and Stone and Webster Engineering Corporation (S\&W) conducted a study to evaluate the technical and economic feasibility of using coal liquids in Northeast oil-fired utility plants. 'l'he Electric Power Research Institute provided advisory services.

The initial study reviewed liquefaction processes, evaluated coal-oil mixtures as a possible interim fuel, assessed potential operating problems, and considered sites for coal conversion plants. A supplemental economic analysis of coal liquids was also conducted.

NECUP then authorized a second phase study which includes the development of plans to obtain coal liquid supplies for testing. The program will continue to review developments in coal liquefaction technology and to identify process schemes that yleld a techically acceptable fuel-oil product. at the least cost to utilities.

Several conclusions can be drawn from the NECUP study:

- The majority of existing oil-fired steam plants cannot be economically converted to coal use

- Environmental restrictions will limit the use of coal in the Northeast region 
Existing oil-fired steam plants will provide a market for coal liquids well beyond their projected availability

- At 70 percent capacity, Northeast plants will consume approximately $425,000 \mathrm{bbl} /$ day by 1990

- At 30 percent capacity, Northeast plants will consume approximately $180,000 \mathrm{bbl} /$ day by 1990

- In new plants, cod liquids may be competitive with direct coal firing for intermediate and peak loads.

- Competitiveness of coal liquids with petroleum fuels is dependent upon the relationship between general price inflation and the escalation rate of petroleum prices. Coal liquids are a competitive fuel choice relative to petroleum (levelized busbar cost criteria) if the inflation rate of petroleum is 1 percent higher than the general inflation rate.

- Equipment redesign and improved combustion control may be required to satisfy $\mathrm{NO}_{x}$ regulations.

- Product sulfur content can be tailored to meet current regulations.

- Particulate emission characteristics are expected to be lower than heavy fuel oil.

The second phase of the study is almost completed. Planned site selection activities encompass discussions with state and local officials, coal producers, transportation companies, and regulatory agencies. NECUP feels it is possible to produce competitive priced coal liquid boiler fuels that will be suitable for firing in utility boilers-in existing oil-fired boilers as well as new peaking and intermediate load service in the near term. 
2. A Successful Combustion Demonstration

Utilizing Distillate Oil From the SRC-II

Process Was Conducted on a Utility Boiler

Located in New York-More Combustion

Demonstrations Will Be Required to Determine

the Suitability of Coal Liquids for Utility

Boilers

A combustion demonstration utilizing distillate

fuel oil from SRC-II process was conducted on a utility boiler located at Consolidated Edison Company in New York. Con Ed as well as other Northeast utilities have supported coal liquid development, because of their large dependence on imported residual oil. The test boiler was a corner-tired, Combustion Engineering, Inc. unit with a rated steam flow of $450,000 \mathrm{lbs} / \mathrm{hr}$. Emissions and boiler performance were investigated at full load, half load and three-quarter load for baseline and low $\mathrm{NO}_{\mathrm{x}}$ (staged combustion) conditions. Approximately 4,500 barrels of SRC-II fuel oil were utilized during the program. Measurements of nitric oxides, oxygen, carbon monoxide, polycyclic organic matter, total unburned hydrocarbons, sulfur, particulate mass and particulate size distribution were obtained. The performance of the fuel oil was also examined with respect to combustion characteristics and adaptation to existing boiler hardware. The No. 6 fuel oil currently burned in the test boilers was also tested to compare with the SRC-II fuel oil.

In general, no major operational problems or adverse boiler performance effects were encountered due to the combustion of SRC-II fuel oil. Nitrogen oxide emissions were nominally 70 percent greater than those obtained for the No. 6 fuel oil. Reductions in $\mathrm{NO}_{\mathbf{x}}$ levels on the order of 35 percent were demonstrated through combustion. modifications with both fuels. Particulate mass emissions were lower with the SRC-II fuel oil while the other emissions measured were essentially equivalent.

Although no major operational problems or adverse boiler performance effects were encountered, more combustion demonstrations will be required to determine the suitability of coal liquids under continuous burn conditions. 
(2) The Mid-Atlantic, South Atlantic and west Regions Also Consume Large Amounts of Boiler Fuels and Would Be Attractive Markets for Coal Liquids

The Mid-Atlantic region, like the Northeast, consumes a sizeable amount of boiler fuels. In 1978, 233,000 barrels/day of boiler fuels were consumed by utilities in Pennsylvania, Virginia, Maryland, Delaware and West Virginia. By 1990, the Mid-Atlantic region is forecast to require 116,000 barrels/day-a market large enough to support several. coal liquid plants.

The Mid-Atlantic region is an attractive market for coal liquids because of its proximity to coal in Virginia and west Virginia. For example, an Appalachia mine-mouth coal liquids facility would require only train transporation to utilities in the Mid-Atlantic region, while deliveries to other regions would require more extensive transporation systems such as barges. This would lend to lower cost and ease of delivery of coal liquids to utilities in this region.

Interviews with utility industry representatives in the Mid-Atlantic region, such as Baltimore Gas and Electric Company and Pililadelphia Electric, indicated that coal liquids could be a potential fuel substitute for residual fuel oil in existing oil-fired steam plants.

Similarly, the South Atlantic region consumes a sizeable amount of boiler fuels. In 1978, 286,000 barrels/day of boiler fuels were consumed by utilities in this region. By 1990, the South Atlantic region is forecast to require 109,000 barrels/day-a market large enough to support several coal liquid plants.

Interviews with the Tennessee Valley Authority (TVA) indicated that TVA would be a candidate utility to purchase coal liquids in cooperation with DOE and coal liquid producers. Florida Power and Lighting Company also has been active in the coal liquids area, and indicated its desire to support coal liquids development.

The West region (Arizona, Nevada, California and Hawaii) is the single largest consuming region of boiler fuels. In 1978, 316,000 barrels/day of boiler fuels were consumed by utilities in this region, mostly in California. By 1990, the West region is forecast to require 596,000 barrels/day-a market which will grow. over 250,000 barrels/day in the next 10 years. 
4. THE UTILITY MAPKET FOP. COAL LIOUIDS IN THE NEAR TEPM WILL BE TO DISPLACE RESIDUAL OIL USED IN EXISTING BOILERS BUT THE LONG-TERM MARKET NILL BE AS A LIOUID FUEL FOR INTERMEDIATE AND PEAK CAPACITY

In 1978, there was a total of 106 GW of oil-fired steam plants and 66 GW of gas steam plants in operation. A majority of the fuel oil consumption in 1978 was to supply base and intermediate loads. As discussed earlier, the President has proposed a program to convert existing oil-fired plants to coal and to encourage utilities to invest in new non-oil-fired generators, thereby retiring existing oil plants earlier than would otherwise occur. As a result, consumption of residual fuel oil is forecasted to decline from 1.6 million barrels/day in 1978 to 800,000 barrels/day by 1090. Further reductions are anticipated by 2000. The reduction in fuel oil consumption will occur, for the most part, as existing facilitles retire (planned or accelerated retirements) and as utilities convert existing plants away from oil to sources such as coal.

(1) The Near-Term Market for Coal Liquids Will Be to Displace Imported Pesidual Oil Used in Existing Boilers in the Northeast, Mid-Atlantic, and South Atlantic Regions

In 1978, approximately 75 percent of all residual oil consumption by electric utilities was imported. Most of those imports went lo east coact utilities, particularly in the Northeast. No discussed earlier, the Northeast, Mid-Atlantic, and South Atlantic regions represent the largest and most attractive near-term markets for coal liquids as a boiler fuel. Since these regiuns mostly coneume imported residual fuel oil, the near-term market will displace imported residual oil.

President Carter's programs to reduce oil use in utility boilers is directed at reducing residual oil imports by switching away from oil to resources such as coal. Under the President's program, the residual oil imports are forecast to decline from 1.2 million barrels per day to approximately 500,000 barrels per day by 1990 . (The assumption was made that domestic production of residual oil remains relatively constant at 300,000400,000 barrels per day.)

The near-term market for coal liquids is then approximately 500,000 barrels per day of imported residual oil. Most of this oil will go to east coast 
utilities, particularly in the Northeast. The size of the imported residual market in 1990, however, will ultimately be determined by the success of the Carter program in achieving its oil reduction goals. This market can be expected to decline even further by. 2000 .

The Long-Term Market for Coal Liquids Hill Be as a Liquid Fuel for New Intermediate and Peak Capacity

Forecasting the market for new technologies designed to burn coal liquids is difficult. For example, there are several different ways of burning coal, including:

- Direct-firing with scrubbing

- Direct-firing, fluidized bed combustion

- Direct-firing, solvent refined coal

- Liquid-firinq; petroleum-type fuel

- Low-Btu gas firing

- Medium-Btu gas firing.

It is difficult to determine the market potential for these technologies because of technical differences among technologies and uncertainties concerning economics of each process. Other factors which bear significantly on the market potential of new technologies include, but are not limited to:

- Chemistry of feedstock requirements

- Status of development of candidate process

- Probability of successful development and cost to commercialization

- Reliability, load characteristics

- Capital and operating costs

- Environmental regulation.

Booz, Allen interviewed utility industry representatives concerning the development of new coal technologies and, specifically, the role of coal liquids. The consensus of opinion of the utility 
industry was that coal liquids in a combined-cycle plant and coal liquids with a combustion. turbine appear to be competitive options in intermediate and peak load service, respectively. However, coal liquids did not appear to be competitive in base load applications with coal gasification and direct firing of coal with scrubbing. The Electric Power Research Institute (EPRI) has been actively involved in evaluating new technology options for utilities.

As an illustration, Exhibit 3-6, show hypothetical generation expansion alternatives (1985-2005) for a "synthetic" electric utility. Only the most economically viable technologies appear; that is, only those generation alternatives by fuel type that have the minimum energy costs for some span of capacity factors appear. As shown, petroleum-type fuel (combined-cycle) appears to be competitive at intermedlate load $(3,000$ hours per year). This also appears to be competitive in the last 1980s. This penetration, of course, is based on a coal liquids price of $\$ 25 /$ barrel (in 1979 dollars). At $\$ 35 /$ barrel, coal liquids for intermediate load does not become competitive until the late 1990s.

This example demonstrates the economic uncertainties and its impacts on determining the potential market for coal liquids in new technologies. Based on discussions with EPRI and other utility representatives, there appears to be a substantial and growing electric utility market potential for coal liquids in new technology applications if present coal liquid development costs are met and imported petroleum prices escalate as projected.

5. RESIDUAL FUEL OIL CONSUMPTION IN INDUSTRIAL BOILERS IS SMALL BUT IS FORECASTED TO GROW FROM APPROXIMATELY 100,000 BARRELS/LAY IN 1975 TU BETWEEN 200,000 AIND 250,000 BARRELS/DAY BY 1990

In 1975, residual and distillate fuel oil consumption was approximately 550,000 barrels/day-approximately 9 percent of total industrial fuel consumption. A summary of fuel consumption forecasts for the industrial sector is shown in Exhibit 3-7. According to discussions with staff personnel at the Energy Information Administration, about 25 percent of the total residual fuel oil consumption in 1975 was used as a boiler fuel; and negligible amouts of distillate were used as a boiler fuel. The remaining residual and distillate fuel oil was for thermal process heat and feedstock applications. This information was based on a Major Fuel-Burning Installation (MFBI) data base compiled by EIA. 
EXHIBIT 3-6

Conceptual Generation Expansion Alternatives 1985-2005

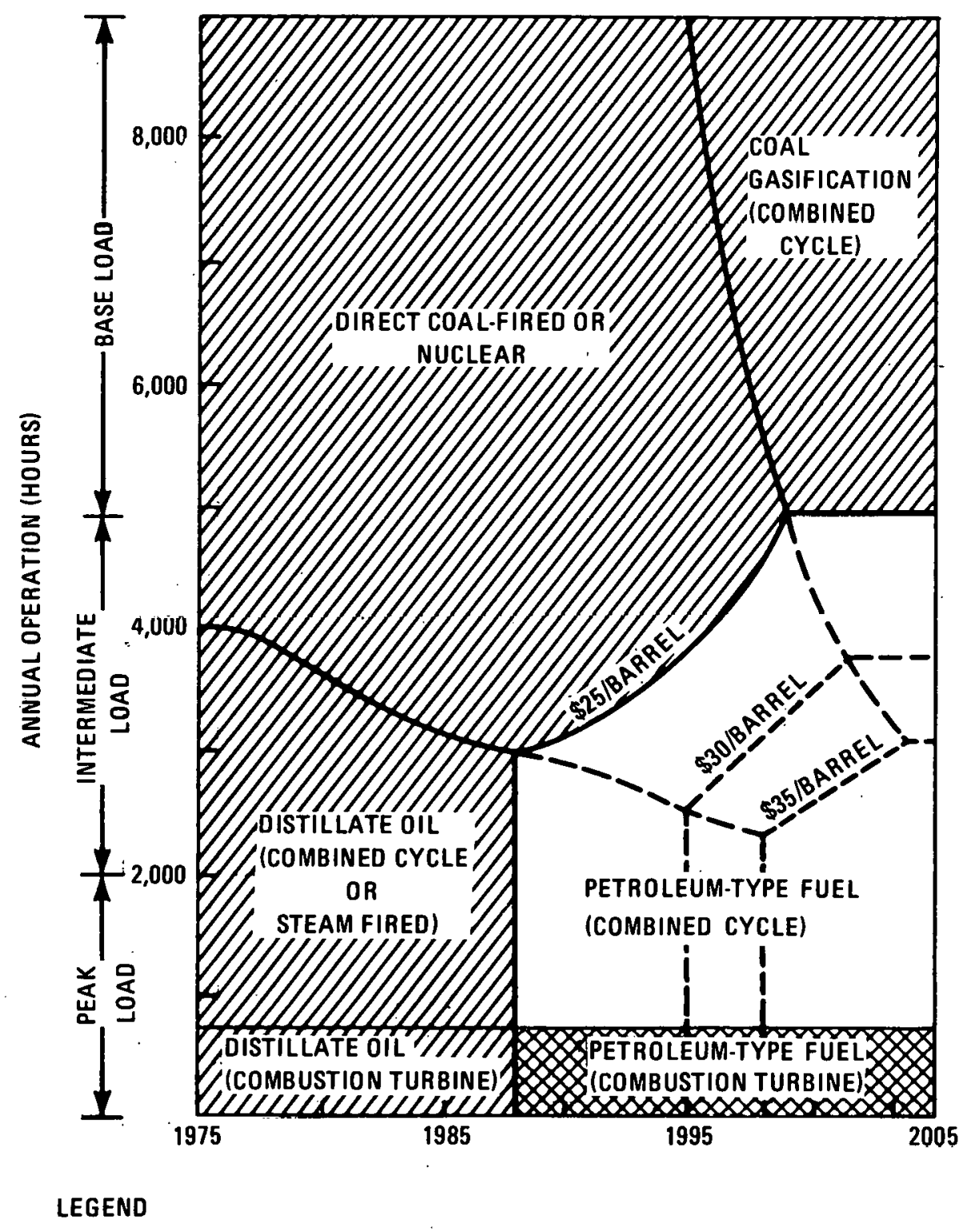

D - MARKET FOR NON-COAL LIQUID TECHNOLOgIES

$\square$ - MARKET FOR COAL LIQUIDS AS A BOILER FUEL

- MARKET FOR COAL LIQUIDS AS A TURBINE FUEL

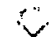

SOURCE: BASED ON AN ARTICLE ENTITLED, “MARKET POTENTIAL FOR NEW COAL TECHNOLOGIES", EPRI JOURNAL, MAY 1978 
EXHIBIT $3-7$

Summary of Fuel Consumption

by Industrial sector

$1975-1990$

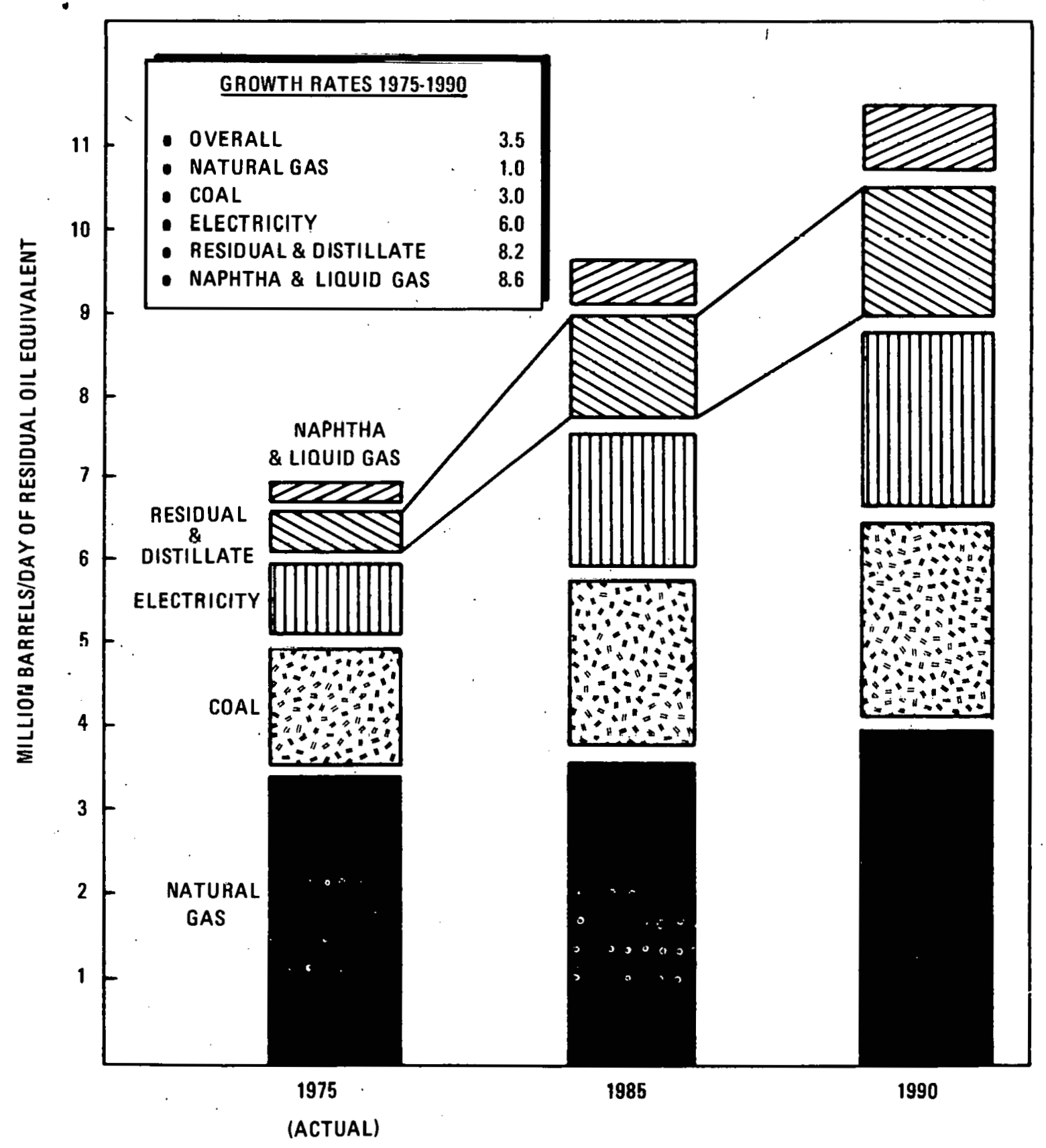

SOURCE: Annual Report to Congress, 1977, Energy Information Administration, DOE and Booz, Allen \& Hamilton line. 
In $1975,86,000$ barrels/day of residual fuel was consumed as a boiler fuel. This market is forecasted to grow to between 200,000 and 250,000 barrels/day of residual fuel oil by 1990. A forecast of industrial fuel consumption by application is shown below:

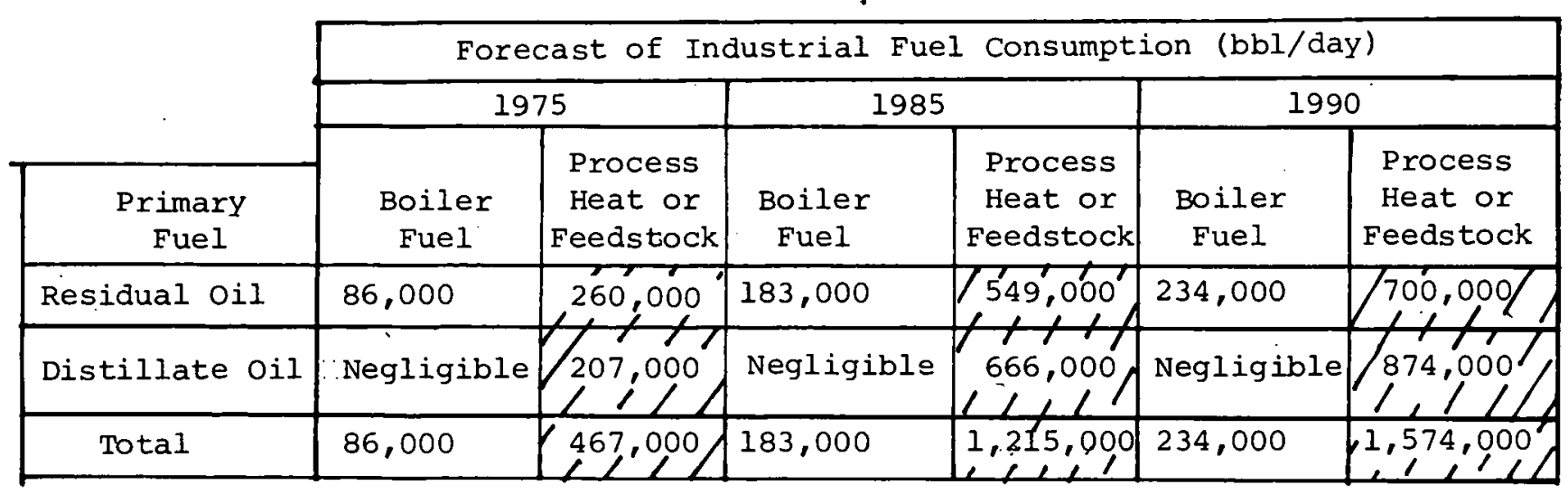

The 1990 forecasts of residual oil and distillate oil consumption have recently been updated by EIA, but detailed regional forecasts were not available to Booz, Allen in time to be incorporated in this study, 1990 forecasts of residual oil used as boiler fuel were revised from 234,000 barrels/day to approximately 200,000 barrels/day. 1990. distillate oil consumption was revised from 874,000 barrels/ day to 218,000 barrels/day. Revised distillate oil forecasts will not affect the market for coal liquids since only a negligible amount of distillate oil is used in industrial boilers.

(1) The Northeast Region, the Mid- and South Atlantic, Midwest, and Southwest Regions Are Likely Candidate Markets for Coal Liquids

Six DOE regions have been selected as probable regional markets for coal liquids as a boiler fuel. based on market size of growth. A summary of regional data of total residual oil consumption and boiler fuel consumption in the industrial sector is shown in Exhibit 3-8. The six attractive DOE regions and their forecasted 1990 boiler fuel consumption of residual oil is summarized on page 3-16. 
EXHIB IT $3-8$

Summary of Regional Data cf Total Residual Oil

Consumption and Boiler Fuel Consumption

in the Industrial sector

\begin{tabular}{|c|c|c|c|c|c|c|c|c|c|c|c|}
\hline Year & New Eng. & NY/NJ & Mid-Att. & S. Atl. & Midwest & S. West & Central & N. Central & Wes.t & N. West & Total \\
\hline 1975 & 48 & 42 & 5 & & & & & 16 & & 16 & \\
\hline 1990 & & & & & & & 18 & 18 & & & \\
\hline
\end{tabular}

Legend:

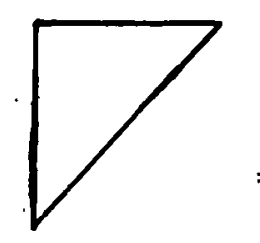

= Represents total regional residual oil consumption

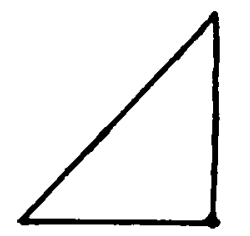

= Represents regional boiler fuel consumption of resịdual oil

Source: Data were obtained from Annual Report to Congress, 1977, Energy Information Administration, D0E and Booz, Allen \& Hamilton Inc. 


\begin{tabular}{|l|c|}
\hline \multicolumn{2}{|c|}{ Candidate Regions for Coal Liquids } \\
\hline Region & 1990 Quantity \\
New England & 26,000 barrels/day \\
New York/New Jersey & 14,000 barrels/day \\
Mid-Atlantic & 19,000 barrels/day \\
South Atlantic & 33,000 barrels/day \\
Midwest & 26,000 barrels/day \\
Southwest & 85,000 barrels/day \\
\hline Total & 203,000 barrels/day \\
\hline
\end{tabular}

As shown, these six regions account for 203,000 barrels/ day (approximately 85 percent of the total forecasted industrial boiler consumption of residual fuel oil). The four remaining regions--Central, North Central, West, and Northwest--account for a total of 32,000 barrels/day of residual boiler fuel (approximately 15 percent of the total boiler fuel market).

The New England and New York/New Jersey area is forecasted to consume 40,000 barrels/day of residual boiler fuel. This area is attractive because of the large consumption of residual oil by electric utilities in this region. Similarly, the Mid-Atlantic, South Atlantic, and Midwest are attractive market regions for coal liquids because of their large boiler fuel consumption (large relative to industrial consumption in other regions) and because of the large consumption of residual oil by electric utilities in these regions.

The Southwest region represents the largest potential market area for coal liquids. Although 1975 residual boiler fuel consumption was 12,000 barrels/day, by 1990, the Southwest is forecasted to require 85,000 barrels/day (approximately 35 percent of the total residual boiler fuel market). This translates into a 14 percent per year growth rate in the southwest for residual boiler fuels. However, residual oil consumption in the Southwest will be dependent on the availability of natural gas.

(2) The Near-Term Industrial Market for Coal Liquids Strongly Depends on the Relative Economics of Coal Liquids, the Impact of Government Policies, and the Availability of Natural Gas

The near-term industrial market for coal liquid strongly depends on the relative economics of coal liquids when compared to residual fuel oil. Interviews 
with several industrial boiler owners who use residual oil, and the Council of Industrial Boiler Owners (CIBO) indicated that the key issue relevant to the industrial market for coal liquids, was the price of coal liquids relative to No. 6 fuel oil. When the price for coal liquids and residual oil become the same, the industrial boiler owners will consider coal liquid purchases. The impact of technical, environmental, regulatory, and institutional barriers on the industrial market for coal liquids will be discussed in detail in subsequent sections.

A key factor which will influence the market for coal liquids is the impact of government policies. The Power Plant and Industrial Fuel Use Act of 1978 established guidelines and regulations pertaining to the use of coal in new industrial boilers and also specified guidelines pertaining to conversion of existing petroleum-fired boilers to coal. The success of the Federal Government to enforce the PIFUA will also strongly determine the market potential for coal liquids. If PIFUA is effective in requiring new industrial boilers to burn coal, then the market for residual oil and thus coal liquids will decrease proportionately.

Finally, the availability of natural gas in the near term for industrial consumption will influence the market for residual oil and substitute coal liquids: Current DOE policy has been to encourage industrial users of residual oil to switch away from oil to natural gas. If this policy continues for several years, then the market for residual oil and thus coal liquids will decrease.

(3) The Long-Term Industrial Market for Coal Liquids Depends on the Impacts of New Technology Development, Including Combined-Cycle systems and Cogeneration Systems

The long-term industrial market for coal liquids strongly depends on the development of new technologies applicable to industrial boilers. Several studies have been conducted which examine the economics of coal liquids in advanced industrial boiler systems. Most of the advanced industrial boiler systems show the potential for greatly improved efficiencies and performance, but 
a key obstacle in their development has been the dependence on liquid fuels. These systems include (but are not. limited to):

- Combined-cycle systems
- $\quad$ Fiesel engines
- Advanced gas turbines.

If these new industrial systems are successfully developed, there would be a growing, long-term market for coal liquids to fuel these systems.

A Cogeneration Technology Assessment Study (CTAS) conducted by General Electric and United Technologies for DOE examined the technical and economic advantages of cogeneration systems for industrial use. The study concluded that lie potentlal market for coal liquids in cogeneration systems could be substantial in the long term; however, this market would most likely be for turbine fuels.

6. THE DEPARTMENT OF DEFENSE CONSUMES A RELATIVELY SMALL PORTION OF ITS TOTAL PETROLEUM CONSUMPTION AS BOILER FUELS

The Department of Defense. (DOD) consumes approximately 35,000 barrels/day of residual fuel oil and 60,000 barrels/ day of middle distillates. A summary of DOD consumption of petroleum products in the U.S. in 1978 is ás follows:

\begin{tabular}{|c|c|c|}
\hline \multicolumn{3}{|c|}{ Summary of U.S. DOD Petroleum Consumption } \\
\hline Fuel Category & $\begin{array}{l}\text { Consumption } \\
\text { (barrels/day) }\end{array}$ & \& of Total \\
\hline $\begin{array}{l}\text { Jet Fuel } \\
\text { Aviation Gasoline } \\
\text { Motor Gasoline } \\
\text { Middle Distillates } \\
\text { Residual Oil }\end{array}$ & $\begin{array}{r}256,000 \\
2,300 \\
12,400 \\
60,200 \\
34,700\end{array}$ & $\begin{array}{r}70 \\
0.5 \\
3.5 \\
16.5 \\
9.5\end{array}$ \\
\hline Total & 365,600 & 100.0 \\
\hline
\end{tabular}


The implication of the DOD market segmentation is that approximately 90 percent of DOD consumption of petroleum products is for transportation purposes (jet.fuel, aviation gasoline, motor gasoline, and most middle distillates). Less than 10 percent of DOD consumption is for residual boiler fuel. In addition, the DOD boiler market is not centralized or localized in one region of the country which would make marketability of coal liquids difficult.

DOD has expressed concern about its vulnerability to energy shortages in Congressional testimony before the Committee on Banking, Finance, and Urban Affairs. But that vulnerability will seriously affect DOD's transportation fuel requirements.

The "Moorehead Bill" has been proposed in Congress to establish a DOD-guaranteed market for the output of synthetic fuels plants. Based on the fuel consumption breakdown shown earlier, if the "Moorehead Bill" is enacted, the coal liquefaction processes currently under development will need to be configured to manufacture transportation fuels and not boiler fuels. The "Moorehead Bill" and similar legislation designed to guarantee a DOD market for coal liquids may serve to limit the market for coal liquids as a boiler fuel since the DOD market is lárgely for transportation fuels. 


\section{CHAPTER 4}

THE POTENTIAL ENVIRONMENTAL HAZARDS OF BOILER FUELS PRODUCED FROM COAL LIQUEFACTION PROCESSES 
CHAPTER 4

THE POTENTIAL ENVIRONIENTAL HAZARDS OF BOILER FUELS PEODUCED FROI COAL LIQUEFACTION PROCESSES

This chapter presents a summary of the assessment of potential environmental hazards of boiler fuels produced from coal liquefaction processes, compared with the hazards of No. 6 fuel oil, the product the coal-derived fuels would most likely replace. Further details are presented in Appendix $B$ of this report.

Booz, Allen has analyzed the environmental hazards of the products from three direct coal liquefaction processes:

- Solvent Refined Coal (SRC-II)
- H-Coal
Exxon Donor Solvent (EDS).

Booz, Allen did not analyze the products from two indirect coal liquefaction processes-Fischer-Tropsch and Methanol Synthesis. Both of these processes yield a liquefied product after gasification of coal. Because of the gasification processing, these products are inherently clean in relation to direct coal liquefaction products and No. 6 fuel oil.

Data on the coal liquefaction products are limited and inconsistent, as the various technologies are at different stages of development. Therefore, the evaluation of environmental hazards was made by combining currently available data, interviews with Government and industry representatives, and judgments made by the study team from evaluating the chemical composition of the products.

The findings represent a prejudgment of current and future testing to determine the environmental hazards of coal liquefaction products. Our analyses show that worker safety and health will be a potential environmental concern. Dermal exposure to the products will have to be reduced in relation to normal handling procedures for conventional fuels. Additionally, there are several areas identified for further evaluation such as biological testing of products, additional utility test burns, and detailed compositional data. The completion of these tests will further define the potential environmental hazards of coal liquefaction products. 
1. THE ENVIRONIENTAL HAZARDS OF PRODUCTS OF THREE DIRECT COAL LIQUEFACTION PROCESSES WERE ASSESSED IN RELATION TO NO. 6 FUEL OIL

Three direct coal liquefaction processes were analyzed: SRC-II, H-Coal, and EDS. The two indirect processes in use today, Fischer-Tropsch and methanol synthesis, were not analyzed for environmental hazards because they are inherently clean. Fischer-ropsch is essentially free from sulfur and nitrogen and has lower concentrations of heavy aromatic compounds than No. 6 fuel oil. Methanol has known hazards but is considered environmentally safe when handled properly.

No. 6 fuel oil is the primary competing substitute product for boiler fuels produced by coal liquefaction. This fuel was chosen because it has been accepted in the markctplacc at ite current level of risk, and its handling prooeduree and environmental safeguards are estahlished.

The specifications for No. 6 fuel oil are functional rather than compositional requirements. Therefore, the composition of No. 6 fuel oil varies according to crude oil source, customer specifications, available distillation cuts, refinery processing, and the blend selected. Exhibit 4-1 illustrates a typical No. 6 fuel oil used in the analysis, which is composed of 45 percent cyelic alkanes (naphthenes), 15 percent alkanes, 25 percent aromatics, and 15 percent polar compounds containing niţrogen, oxygen, or sulfur.

Illinois No. 6 coal was used as a feedstock for each of these three processes because of its availability and compatibility. This coal has been commonly used for previous development work, so that analyses of Illinois No. 6 coal are well documented.

2. LIMITED DATA ARE. AVAILABLE ON THE PRODUCTS OF DIRECT COAL LIQUEFACTION PROCESSES BUT CHEMICAL COMPOSITION PROVIDES A MEANS OF ANALYSIS

In order to assess the hazard potential of direct coal liquefaction products, literature searches and personal interviews were conducted to obtain the current state of the art. It has been found that much work has been done on characterizing the hazardous properties of coal tars, runoff from coal wastes, and coal residues of traditional coal 
EXHIBIT 4-1

Typical Compositional Data for Bunker C Fuel (No. 6 Fuel)

\section{CHEMICAL GROUP ANALYSES}

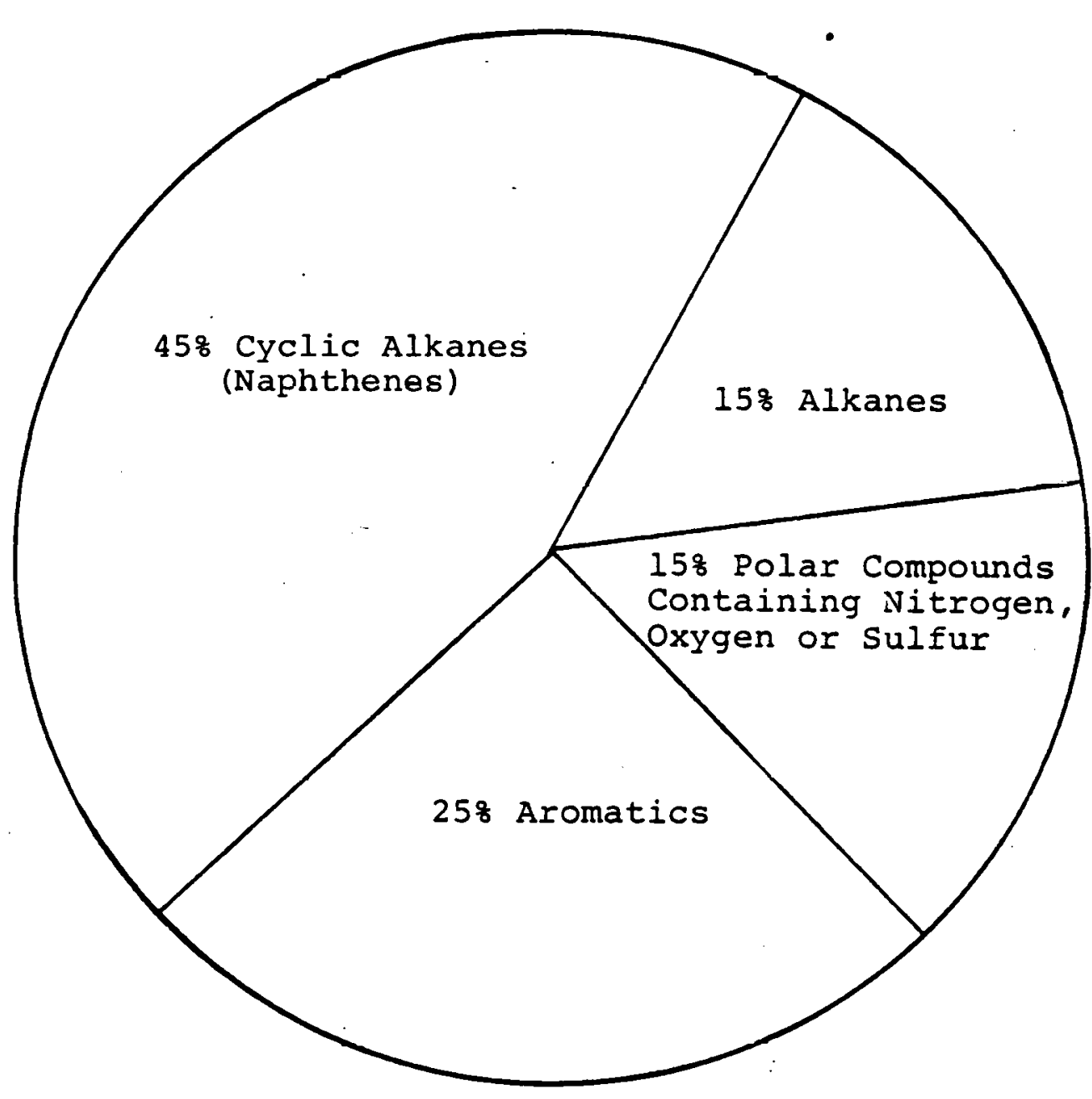

SOURCE: National Oceanic and Atmospheric Administration Report ERL MESA-17, October 1977

API Report AID.IBA.74, February 1974 
processing plants. Limited quantitative data are available relating to products of direct coal liquefaction processes:

- The epidemiological data available from the Institute, West Virginia Liquefaction Plant (operated during 1952 to 1960) may not be applicable to the products of current direct coal liquefaction processes.

- Toxicological testing programs on SRC-I products were carried out by Industrial Bio-Test Laboratories. This laboratory is virtually shut down and the program status cannot be reported.

- Other toxicological studies are just being started. An extensive toxicological program on both SCR-I and SRC-II materials was sent in 1979 to nine laboratories as an Invitation to Bid on environmental research. The bids are currently being evaluated. The research program includes acute, dermal, inhalation, teratogenic, and mutagenic studies.

- Test burn data are available but limited because of short-term duration and brief analyses performed.

The approach used to determine the potential hazards of direct coal liquefaction products was to compare chemical groupings at four levels of analysis-ultimate analysis, chemical groups, chemical compounds, and trace elements. Then, based on the effect of similar chemical groupings found in products in other industries where hazards are known, preliminary conclusions can be drawn. These four levels of analysis were chosen because:

- Combustion products can be predicted from the ultimate analyses and can be used to develop comparative emission data.

- Groups of known or suspected carcinogens and toxic chemicals can be identified and compared by relative concentrations.

- Toxicity and carcinogenic potentials of direct coal liquefaction products and No. 6 fuel oil can be compared by determining the relative concentrations in each product of the more common hazardous chemical compounds that are usually identified with coal conversion products. 
3. HAZARDS RELATED TO THE THREE TYPES OF DIRECT COAL LIQUEFACTION PRODUCTS ARE SIMILAR BECAUSE SIMILAR COAL, PROCESSES, AND OPERATING CONDITIONS ARE USED

There are basic similarities between the processes and their operating conditions. Unit operations are similar. Operating temperatures, pressures, and yields are basically the same for the three direct coal liquefaction processes. In addition, although analyses of the products are limited, similarities can be seen among the available data. The similarities indicate that the hazard from the products of the direct coal liquefaction processes cannot be differentiated well enough to cite differences among the individual processes.

The composition of the direct liquefaction products is likely to vary nore wilh lhe suurce of cual selected than with process differences. The analysis was based on one coal source, Illinois No. 6. Therefore, the three processes presented similar relative hazards. If a different feedstock coal was selected for analysis of each process, the potential environmental hazards would have minor differences. However, the findings presented in this chapter probably would not change.

4. THE ENVIRONIENTAL HAZARDS OF DIRECT COAL LIQUEFACTION PRODUCTS WERE ASSESSED FOR BOTH ROUTINE AND EPISODAL EVENTS TO DETERMINE AIR AND WATER POLLUTION AND GROUND CONTAMINATION

Environmental impact judgments were made for routine tasks such as loading and unloading, cleanup, storage, transporation, processing, sampling, and analysis of products and for episodal events occuring during routine tasks such as accidents, spills, leaks, or incomplete combustion.

The analysis shows few air pollution problems during routine operation, but good maintenance practices should be implemented to ensure employee safety from routine vapors and leaks. A test burn conducted at Consolidated Edison in September 1978, showed that the higher nitrogen content SRC-II fuel met all of the current emission standards for conventional petroleum-derived fuel oil. It is possible that sulfur and nitrous oxide emissions for direct coal liquefaction products may not differ from those of No. 6 fuel oil because of the variable nature of both products. Polycyclic aromatic hydrocarbon emissions from coal liquids will be nominally higher than for No. 6 fuel oil but will be within acceptable limits. Polycyclic aromatic hydrocarbon emissions from coal liquids will be a function of combustion efficiency. An incomplete combustion 
emission of polycyclic hydrocarbons could present problems. Test burns comparing No. 6 fuel oil and liquefied coal products under upset conditions must be conducted to provide definitive answers to this issue. Emissions of ashes and trace elements caused by incomplete combustion of direct coal liquefaction products should be similar to those of No. 6 fuel oil, but further testing is needed to be certain.

Water pollution problems, caused by spills and disasters, are similar for coal liquefaction products and No. 6 fuel oil. Control measures used by Con Ed in transporting SRC-II Iiquid by barges and tankers can be used as a model for worker and environmental protection. These procedures include steam cleaning and drying barges before use; electrically grounding tank cars, barges, and unloading lines; and flushing empty tank cars and lines with nitrogen to clear lines and to avoid spills when loading barges.

Ground contamination is not expected to become a major problem because products could be transported and stored in closed systems. Leaks, pipeline breaks, and road and rail tanker accidents can be handled with current petroleum industry practices. The clean-up techniques to remove products involve physical containment-blocking and trenching, removal and recovery, disposal, and restoration of the area. These techniques prevent the risk of explosion, fire, and toxic effects from an uncontrolled release of liquids.

5. DIRECT COAL LIQUEFACTION PRODUCTS ARE POTENITALLY MORE HAZARDOUS TO WORKERS THAN NO. 6 FUEL OIL

Analyses of the products of direct coal liquefaction, in terms of both chemical groups and chemical compounds, show that there are greater concentrations of hazardous components when compared to No. 6 fuel oil:

The comparatively greater amounts of polycyclic aromatic hydrocarbons are primarily responsible for the judgment of increased toxicity of direct coal liquefaction products. There are approximately two to three times more polycyclic aromatic hydrocarbons in coal liquids than in No. 6 fuel oil.

- In addition, coal liquids contain:

- Approximately two to three times the concentration of Indans/tetralins as No. 6 Euel oil. 
- Approximately three times the concentration of Pyrenes as No. 6 fuel oil

- Over 7 percent chrysenes; no chrysenes were found in the No. 6 fuel oil tested.

The danger to individuals comes from dermal contact with the coal products. Maintenance workers and materials handlers would have the greatest exposure to liquid products, from maintenance and cleanup of loading, unloading, storage, and transporting equipment. A NIOSH criteria document for control measures in coal gasification plants has been issued and can be used as a guideline for handling coal liquefaction products. The NIOSH coal gasification criteria document provides recommendations for health and safety standards for occupational exposures, including:

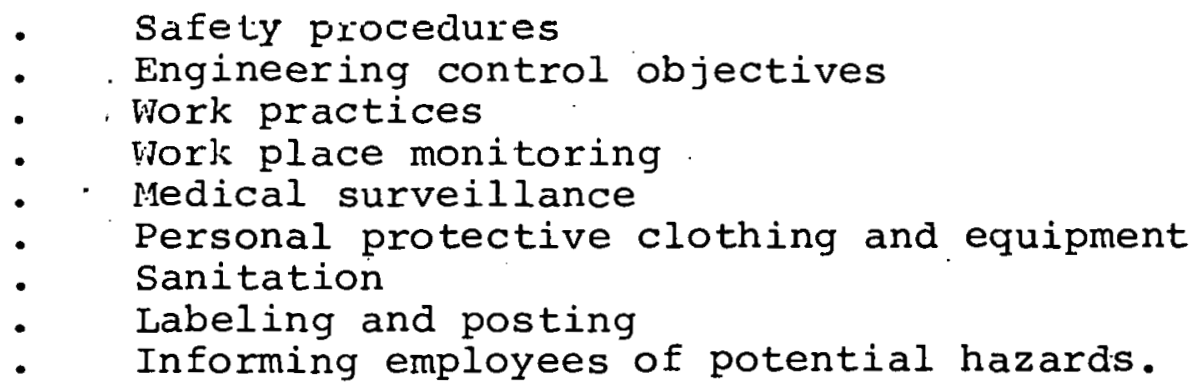

The document discusses biological effects of health hazards of the Institute, West Virginia Coal Liquefaction Pilot Plant.

The Institute plant sludy (published in Lhe Archives of Environmental Health) states that the statistical evaluation showed only an increased incidence of skin tumors. The study showed that skin cancer incidence was at least 20 times as high as the expected incidence. However, this factor assumed a worst-case situation using data on all skin abnormalities observed, whether or not there was agreement among the pathologists that they were cancers. NIOSH recommends a comprehensive employee protection program that may be applicable to handlers of direct coal liquefaction products. This program includes:

- Medical surveillance:

- Preplacement medical examination

- Periodic examination

- Records of employee exposures to coal products. 
- Personal protective clothing and equipment:

- Impervious gloves

- Protective clothing for protection from specific hazards

- Eye protection, including full face shields and respirators, when applicable

- Sanitation:

- Clean change rooms with storage for street clutlies

- Separate storage facilities for work garments, protective clothing, and equipment

- Clean and dirty change rooms separated partially by a shower facility and partially by one-way doors

- Cleaning, laundering, or disposal of contaminated protective clothing

- Prohibition against food or beverages in potential areas of exposure

- Employees' use of soap and water, not chemical solvents, to remove materials from skin

- Employee training:

- Instruction in good hygiene practices and potential hazards of job

- Continuing éducation and personnel monitoring program.

5. IN SUIMARY, THE PRODUCTS OF DIRECT COAL LIQUEFACTION PROCESSES REPRE'SENT A SLIGHTLY GREATER ENVIRONMENTAL HAZARD THAN NO. 6 FUEL OIL, BUT THESE HAZARDS CAN BE CONTROLLED WITH ADEQUATE SAFEGUARDS

The primary environmental area of concern with direct coal liquefaction products is worker health and safety. Dermal contact is the primary means of exposure to the products' carcinogenicity and toxicity. Work place controls must be employed to minimize dermal exposure to direct coal liquefaction products. A summary of the hazards of direct coal liquefaction products relative to No. 6 fuel oil is presented in Exhibit 4-2. 
EXH IBIT $4-2$

Capsule Summary o

Coal Liquefaction Products Relative to No. 6 Fuel oil

Foutine Ever.ts

Potential Hazard

Relative to No. 6 Fuel oil

Environmental Area

Norker safety \& Health

$\oplus$

$\Theta$

(0)

Ground Contamination

$\Theta$

\section{Episodal Events}

Potential Hazard Relative to No. 6

Discussion

Controls would include good work practice and hygiene procedure

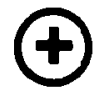
dards should be met-so $_{x}$ less, $\mathrm{NC}_{x}$ higher

Mandated controls measures analogous to No. 6 Fuel Oil will be required

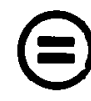

Routine clean-up anc disposal of spills and leaks similar to No. 6 Fuel oil
Discussion

Dermal exposure during clean-up operations will have to ke controlled to minimize hazard

Possible increase in polycylic

aromatic compounds and particulates-more testing is needed

Tanker or barge accidents could have major environmental impact-similar to crude oil

Severe exposures must be controlled more stringently than No. 6 Fuel oil

(4) Greater Hazard Potential Than No. 6 Fuel oil

(Dess Hazard Potential Than No. 6 Fuel oil

(Approximately Equal Hazard Potential To №. 6 Fuel Jil

Source: Booz, Allen \& Hamilton Inc. 
CHAPTER 5

REGULATORY ISSUES ASSOCIATED WITH MARKETING

COAL LIQUEFACTION PRODUCTS AS BOILER FUELS 
CHAPTER 5

REGULATORY ISSUES ASSOCIATED WITH MARKETING COAL LIQUEFACTION PRODUCTS AS BOILER FUELS

The Environmental Protection Agency and the Department of Energy administer the major programs that will affect the commercial development of coal liquefaction products as boiler fuels. The Environmental Protection Agency administers the New Stationary Source Performance standards for electric utility steam generating units. The Department of Energy administers the Power Plant and Industrial Fuel Act of 1978. While the provisions of these regulatory programs may offer encouragement to coal liquids market development, the industrial sector is not sure how they will be implemented, and this will delay purchasing decisions.

The development of coal liquefaction technologies may be additionally constrained by other regulations imposed to protect health, safety, and the environment. Various regulatory programs may involve higher capital and operating costs. These increased costs will be reflected in the price of the products produced. The magnitude of the price effects will be conditioned by the conclusions drawn from research currently in progress.

The major regulatory programs affecting coal liquefaction to market development are shown in Exhibit 5-1 and are discussed below.

1. NEW STATIONARY SOURCE PERFORMANCE STANDARDS FOR ELECTRIC UTILITY STEAM GENERATING UNITS GOVERN NO $x$ AND $S O_{x}$ EMISSIONS AND WILL AFFECT THE UTILIZATION OF COALDERIVED LIQUIDS

Coal liquefaction boiler fuels appear to meet the New Source Performance Standards but additional large-scale testing will be required to completely ascertain regulatory compliance. There are some waivers granted for the use of coal liquefaction boiler fuels. The major provisions of the New Source Performance Standards regarding the use of coal liquids are:

$\mathrm{SO}_{2}$ emissions to the atmosphere are limited to $1.20 \mathrm{lb} / \mathrm{million}$ Btu heat input, and a 90 percent reduction in potential $\mathrm{SO}_{2}$ emissions is required at all times except when emissions to the atmosphere are less than $0.60 \mathrm{lb} / \mathrm{million}$ Btu heat input. Tests to date indicate that coal liquefaction products should meet this standard. 


\section{EXHIBIT 5-1 \\ Impact of Various Regulatory Programs on Coal Liquefaction Market Development}

Regulatory Program

Clean Air Act, New Source

Performance Standards
Imoact

$\theta$

Remarks

Governs $\mathrm{SO}_{2}, \mathrm{NO}_{x}$, and particulate matter emissions; permits and waivers may be granted for coal liquefaction; however, additional testing will be required to establish regulatory compliance.

Power Plant and Industrial

Fuel Use Act

Mandates conversions to coal from oil and gas; temporary exemptions may be granted for use of synthetic fuels; however, implementing authorities are not yet final, and synthetic fuels are not yet available. Long iitigation is expected on implementation.

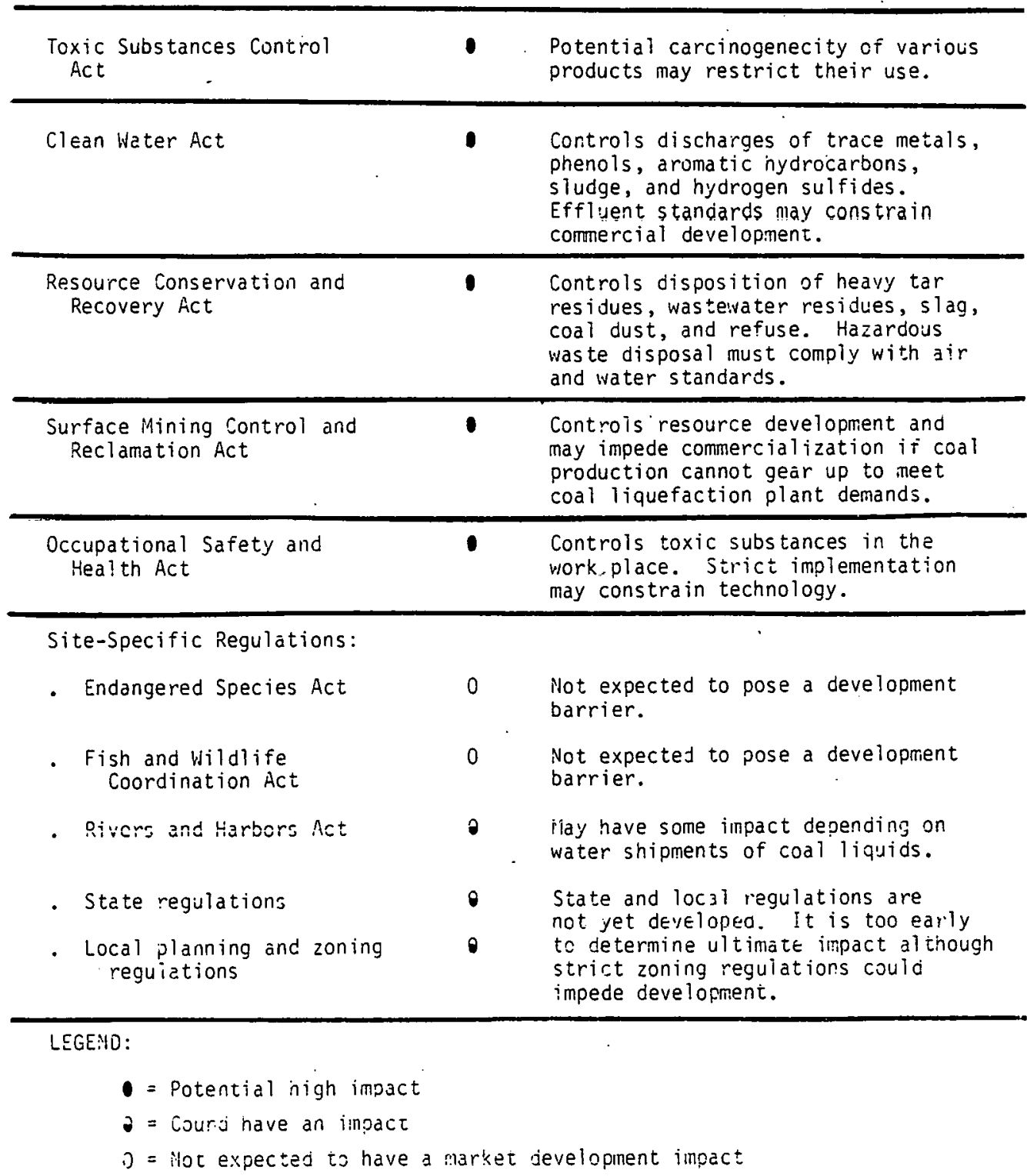


- The Particulate Matter Standard limits emissions to $0.03 \mathrm{lb} / \mathrm{mill}$ ion Btu heat input. Coal liquefaction products are expected to meet this criteria.

- The $\mathrm{NO}_{\mathrm{x}}$ Standard is $0.50 \mathrm{lb} / \mathrm{mill}$ ion Btu heat input from the combustion of liquid fuels derived from coal. Additional testing of coal liquefaction products, particularly the EDS and H-Coal boiler fuels, will be required to substantiate coal liquids' ability to be in regulatory compliance in this area.

(1) Commercial Demonstration Permits May Be Granted for Certain Technologies, Including Coal Liquefaction

The EPA Standards include provisions that allow the granting of commercial demonstration permits for less stringent air quality requirements. These provisions provide that facilities using coal liquefaction fuels would be subject to the emission limitation and percentage reduction requirement of the $\mathrm{SO}_{2}$ standard and to the Particulate latter Standards. The $\mathrm{NO}_{\mathrm{x}}$ emission limitation allowed under a commercial demonstration permit for the initial full-scale demonstration plants using coal liquefaction products as boiler fuels, however, would be relaxed to allow $0.70 \mathrm{lb} / \mathrm{million}$ Btu heat input. This may encourage the use of coal liquefaction boiler fuels.

\section{Emissions Waivers for a Period of Up to seven Years} lay Be Granted

These waivers would be in effect from the date of issuance for a periud of seven years or for a period of four years from the start of operation of a facility, whichever is less. The provisions are designed to mitigate the potential impact on emerging technologies such as coal liquefaction and to ensure that the standards do not preclude the development of such emerging technologies. The EPA will issue commercial demonstration permits for the initial demonstration facilities using coal liquefaction products.

2. THE POWER PLANT AND INDUSTRIAL FUEL USE ACT OF 1978 PROHIBITS AND RESTRICTS THE USE OF PETROLEUM AND NATURAL GAS BY EXISTING AND NEW ELECTRIC POWERPLANTS AND PROVIDES EXEMPTIONS FOR THE ANTICIPATED USE OF COAL LIQUEFACTION BOILER FUELS

The Economic Regulatory Administration is authorized to prohibit or restrict the use of petroleum and natural 
gas by electric powerplants and major fuel-burning installations. The prohibitions and exemptions provided for in the Fuel Use Act apply to four major categories of users.

\section{(1) New Powerplants}

New powerplants may be granted an exemption from the requirements of the Fuel Use Act based upon the future use of a synthetic fuel derived from coal. The temporary exemption may be granted for a period of up to five years and may be extended for an additional five years, not to exceed a total of ten years.

New Installations

New installations may be granted a temporary exemption from the provisions of the Fuel Use Act based upon the future use of a synthetic fuel derived from coal. As in the case of new powerplants, the temporary exemption may be granted for a period of up to five years and may be extended for an additional five years, not to exceed ten years.

\section{(3) Existing Powerplants}

A temporary exemption from the provisions of the Fuel Use Act may be made for existing powerplants based upon the future use of a synthetic fuel derived from coal. A temporary exemption may be granted for a period of up to five years and may be extended for an additional five years. The total exemption may not be for a period greater than ten years.

Existing powerplants which used an alternate fuel as a primary energy source at any time during 1977 may not use petroleum as a primary energy source in excess of the amounts used in 1977. The DOE may prohibit an existing power plant from using natural gas or petroleum as a primary energy source provided the powerplant has the technical capability to use an alternate fuel as a primary energy source, that the powerplant could have such capability without substantial physical modification or substantial reduction in its rated capacity, and that the powerplant is financially able to use an alternate fuel. 
A temporary exemption from the provisions of the Fuel Use Act may be granted for existing installations based upon the future use of a synthetic fuel derived from coal. A temporary exemption may be granted for a period of up to five years and may be extended for an additional five years. The total exemption may not be for a period greater than ten years.

Existing installations may be prohibited from using petroleum or natural gas as a primary energy source provided that the installation has or had the technical capability of using an alternate fuel as a primary energy source, that the installation could have such capability without substantial physical modification or substantial reduction in its rated capacity, and that $i t$ is financially teasible to use an alternate fuel.

3. COAL LIQUEFACTION MARKET DEVELOPMEN'I MAY BE IMPACTED BY ADDITIONAI REGULAT IONS DESIGNED TO PROTECT HEALTH, SAFETY, AND THE ENVIRONMENT

Development of commercial coal liquefaction facilities and subsequent product market development will be affected by a variety of additional regulatory programs administered by the Environmental Protection Agency.

(1) The Toxic Substances Control Act May Delay Deployment of Coal Liquefaction Technologies

Coal liquefaction products may require treatment as toxic chemicals. (See Chapter 4 and Appendix B.) Additionally, catalysts containing heavy metals used in the process technologies may be restricted. These factors may constrain technology commercialization.

(2) The Clean Water Act will Govern Water Pollution Found in the Net Discharge From wastewater Associated with Lilquefaction Plants

Coal liquefaction plants. should be sited to minimize environmental impacts. Research to assess water quality is underway in the regions where development of coal liquefaction facilities is anticipated. Results will provide data on which informed judgments can be made regarding plant siting. 
(3) The Resource Conservation and Recovery Act Will Affect Handling and Disposal of the Residues of the Liquefaction Process

Research on solid wastes and solvent extracts to evaluate carcinogenicity and toxicity is currently in progress. The solid residuals include mineral residue, sludge from water treatment, char, heavy tar residues, and process reagents. Waste management practices for these residual compounds will need to comply with emerging Resource Conservation and Recovery Act standards.

(4) The Surface Mining Control and Reclamation Act Is Not Applicable Directly to Liquefaction Processes But Will Be Applied to Coal

The regulatory programs under this Act control coal mining impacts. This Act may potentially have a high impact on process technology development. A large saale-up to commercialization will be dependent upon the ability to significantly increase coal production. Strict application of the surface Mining Control and Reclamation Act will constrain coal liquefaction commercialization.

(5) The Occupational Safety and Health Act Controls Exposures to Hazardous substances

This Act could have a potentially high impact on technology development and ultimate product marketability. The Act requires the implementation of industrial hygiene and safety programs including medical surveillance of workers and training in personal hygiene relative to liquefaction materials. Additionally, stringent standards regarding exposure to hazardous materials may affect market development for coal liquefaction products.

(6) Site-Specific Regulatory Programs May Constrain Technology Commercialization and Ultimate Market Development

Siting of coal liquefaction facilities may be affected by the implementation of other Federal regulatory programs and state and local statutes:

- The Endangered Species Act will govern the construction and operation of coal liquefaction facilities. The Act protects certain 
animal species and a multitude of endangered plant species may be added.

The Fish and Wildlife Coordination Act requires coordination among all Federal agencies to minimize wildlife impacts.

- The Rivers and Harbors Act regulates activities in navigable waterways and requires permits for barge docks, structures over water, and movement of hazardous materials.

- State regulations will govern land, water, and air pollution at the state level.

- Local planning and zoning laws will require Iiquefaction plant sites to conform to local. zoning ordinances. Local communities are just getting involved in process technology plant siting and delays may develop in locating plants when commercialization moves forward. 
CHAPTER 6

INSTITUTIONAL ISSUES 
CHAPTER 6

INSTITUTIONAL ISSUES

There are various institutional issues that will need to be resolved before a large coal liquefaction boiler fuel market is established. Institutional constraints to the marketability of coal liquefaction boiler fuels may enhance, prevent, or delay the commercial development of the process technologies and subsequent market development. The factors and barriers that. were identified during the course of this study and that will affect market development can be aggregated into seven areas:

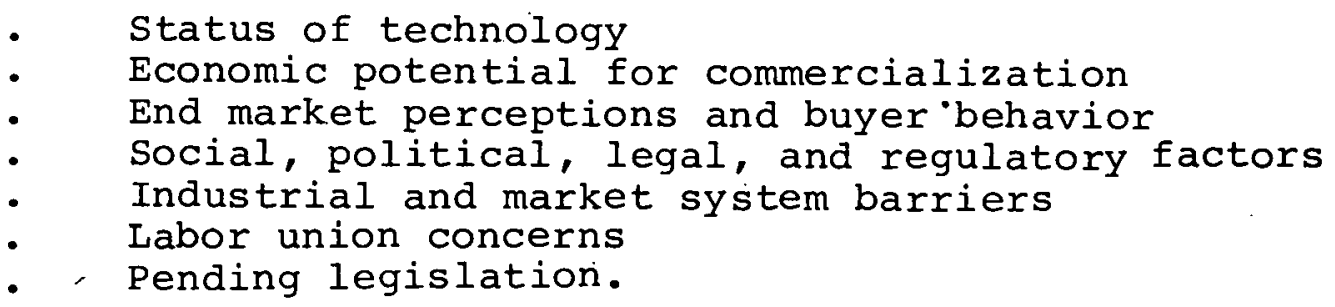

Each of these areas is discussed. Exhibit 6-l highlights these issues in greater detail.

1. ADDITIONAL TEST BURNS ARE NECESSARY TO DEMONGTRATE THE COMBUSTION SUITABILITY OF COAL-DERIVED LIQUIDS

The basic technical feasibility and availability of the basic technology should be demonstrated through additional test burns in candidate utility and industrial boiler fuel markets. Potential boiler fuel market representatives are familiar with coal liquefaction technology and its application to boiler fuel production. However, full-scale combustion suitability for each process technology must still be demonstrated. Industry would like additional test burns conducted for each of the direct coal liquefaction processes. H-Coal and EDS are relative unknowns in the marketplace because large-scale commercial tests have not yet been conducted.

2. $\therefore$ THE ECONOMIC POTENTIAL FOR COMMERCIALIZATION MUST BE SHOWN

The competitive advantage of the technology as compared against alternative ways of burning coal, or as compared against alternative energy sources, must be demonstrated. The economic competitive advantage will provide the major force for pulling the technology through the industrial and market system. The potential users of coal Iiquefaction 
EXHIBIT 6-1 (1)

Issues Affecting Maricetability of Coal Liquefaction Products as Boiler Fuels Based on Perceptions of Actors

\begin{tabular}{|c|c|c|c|c|c|c|}
\hline$\underbrace{\text { ACTOORS }}_{\substack{\text { ISSUE CATEGORY } \\
\text { AND PROBLEM }}}$ & $\begin{array}{l}\text { PROCESS } \\
\text { TECHNOLOGY } \\
\text { COMPANIES }\end{array}$ & UTILITIES & $\begin{array}{l}\text { INUUSTRIAL } \\
\text { BOI LER } \\
\text { USERS }\end{array}$ & $\begin{array}{l}\text { INDUSTRIAL } \\
\text { BOJ.LFR } \\
\text { IIANUFACTUREIRS }\end{array}$ & $\begin{array}{l}\text { FINAN } \approx \text { IAL } \\
\text { COMMUNITY }\end{array}$ & $\begin{array}{l}\text { REGULAATORY } \\
\text { AGENCIFS }\end{array}$ \\
\hline $\begin{array}{l}\text { 1. TECHNICAL } \\
\text { Availability } \\
\text { of technical } \\
\text { information }\end{array}$ & $\begin{array}{l}\text { - } \\
\text { All companies indi- } \\
\text { cate sufficient } \\
\text { information is } \\
\text { available for } \\
\text { demonstration } \\
\text { plant development: } \\
\text { additional informa- } \\
\text { tion needed to go } \\
\text { commercial. }\end{array}$ & $\begin{array}{l}\text { Most utilities con- } \\
\text { tacted have exist- } \\
\text { ing technical in- } \\
\text { formation; Con Ed } \\
\text { test provided addi- } \\
\text { tional information; } \\
\text { many utilities do } \\
\text { not have technical } \\
\text { data on coal. } \\
\text { liquids. }\end{array}$ & $\begin{array}{l}\text { Some industriai } \\
\text { users have coa: } \\
\text { liquid data but } \\
\text { data not widely } \\
\text { disseminated among } \\
\text { total boiler popu- } \\
\text { lation Lack of } \\
\text { sufficient informa- } \\
\text { tion by boiler } \\
\text { owners precludes } \\
\text { decision on use. } \\
\text {. }\end{array}$ & $\begin{array}{l}\text { The major indus- } \\
\text { trial manufacturers } \\
\text { have the product } \\
\text { specifications. } \\
\text { They want addition- } \\
\text { al technical data } \\
\text { as it is developed. } \\
\text { The "scond tier" } \\
\text { boiler manufactur- } \\
\text { ers are familiar } \\
\text { with the liquefac- } \\
\text { tion processes } \\
\text { and products. They } \\
\text { would like addi- } \\
\text { tional technical } \\
\text { information to } \\
\text { evaluate. }\end{array}$ & $\begin{array}{l}\text { The investment } \\
\text { bankers contacted } \\
\text { are familiar with } \\
\text { coal liquefaction } \\
\text { processes and prod- } \\
\text { ucts generally } \\
\text { but do not have } \\
\text { any technical in- } \\
\text { formation. They } \\
\text { would like to have } \\
\text { technical specifi- } \\
\text { cations of prcducts } \\
\text { to analyze. }\end{array}$ & $\begin{array}{l}\text { EPA and NIOSH } \\
\text { have technical } \\
\text { data and are } \\
\text { conducting } \\
\text { environmental } \\
\text { research on coal } \\
\text { liquefaction } \\
\text { products. }\end{array}$ \\
\hline $\begin{array}{l}\text { Technical } \\
\text { feasibility } \\
\text { for commer- } \\
\text { cialization }\end{array}$ & $\begin{array}{l}\text { hil companies } \\
\text { believe that pro- } \\
\text { cesses are tech- } \\
\text { nically feasible, } \\
\text { but believe demon- } \\
\text { stration plants } \\
\text { must be built to } \\
\text { prove commerciali- } \\
\text { zation readiness. }\end{array}$ & $\begin{array}{l}\text { Utilities indicate } \\
\text { that processes are } \\
\text { technically feasi- } \\
\text { ble to produce } \\
\text { acceptable boiler } \\
\text { fuel, but are not } \\
\text { sure o⿸ commer- } \\
\text { cialization } \\
\text { readiness. }\end{array}$ & $\begin{array}{l}\text { Users comfortable } \\
\text { with technical } \\
\text { feasibility of } \\
\text { processes, but are } \\
\text { not sure of conumer- } \\
\text { cialization } \\
\text { readiness. }\end{array}$ & $\begin{array}{l}\text { Majors and "second } \\
\text { tier" companies be- } \\
\text { lieve that proces- } \\
\text { ses are technically } \\
\text { feasible, but are } \\
\text { not sure of commer- } \\
\text { clalization } \\
\text { readiness. }\end{array}$ & $\begin{array}{l}\text { Investment banking } \\
\text { commanity not sure } \\
\text { of technical feasi- } \\
\text { bilizy and very } \\
\text { pessimistic on } \\
\text { commercialization } \\
\text { readiness. }\end{array}$ & $\begin{array}{l}\text { EPA and NIOSH be- } \\
\text { lieve that pro- } \\
\text { cesses are not } \\
\text { yet technically } \\
\text { feasible and be- } \\
\text { lieve more research } \\
\text { must be conducted } \\
\text { before commercial- } \\
\text { ization will be } \\
\text { allowed to take } \\
\text { place. }\end{array}$ \\
\hline $\begin{array}{l}\text { Market accep- } \\
\text { tability based } \\
\text { on known speci- } \\
\text { j.fication. }\end{array}$ & $\begin{array}{l}\text { All companies be- } \\
\text { lieve products will } \\
\text { be accepted by the } \\
\text { market. }\end{array}$ & $\begin{array}{l}\text { Utilities will buy } \\
\text { based on current } \\
\text { knowledge of speci- } \\
\text { Eications. }\end{array}$ & $\begin{array}{l}\text { Boiler operatoxs } \\
\text { will buy based on } \\
\text { current knuwlerge } \\
\text { of specifications. } \\
\text {. }\end{array}$ & $\begin{array}{l}\text { Manufacturers could } \\
\text { retrofit existing } \\
\text { boilers to accept } \\
\text { coal iquefaction } \\
\text { direct products as } \\
\text { boiler fuels. }\end{array}$ & $\begin{array}{l}\text { Investment bankers } \\
\text { have littla per- } \\
\text { ception of coal } \\
\text { liquefaction } \\
\text { boil gr fuel mar- } \\
\text { ket. }\end{array}$ & $\begin{array}{l}\text { EPA and NIOSH } \\
\text { believe that } \\
\text { there are too } \\
\text { many environ- } \\
\text { mental and } \\
\text { health ques- } \\
\text { tions to be } \\
\text { answered before } \\
\text { marketing can } \\
\text { begin. }\end{array}$ \\
\hline
\end{tabular}


EXHIBIT 6-1 (2)

\begin{tabular}{|c|c|c|c|c|c|c|}
\hline ISSUE CATEGORY & $\begin{array}{l}\text { PROCESS } \\
\text { TECHNOLOGY } \\
\text { COMPANIES }\end{array}$ & |UTILITIES & $\begin{array}{l}\text { INDCSTREAI } \\
\text { BOILER } \\
\text { USEFS }\end{array}$ & $\begin{array}{l}\text { INDUSTRIAL } \\
\text { BOILER } \\
\text { MANUFACTURERS }\end{array}$ & $\begin{array}{l}\text { FINANCIAL } \\
\text { ZOMMUNITY }\end{array}$ & $\begin{array}{l}\text { REGULATORY } \\
\text { AGENCIES }\end{array}$ \\
\hline $\begin{array}{l}\text { - Additional } \\
\text { Testing }\end{array}$ & $\begin{array}{l}\text { All companies be- } \\
\text { lieve additional } \\
\text { test burns would } \\
\text { be useful. }\end{array}$ & $\begin{array}{l}\text { Utilities be-ieve } \\
\text { additional test } \\
\text { burns are required. } \\
\text { Utilities in North- } \\
\text { east would like to } \\
\text { conduct H-cocl and } \\
\text { EDS tests, as well } \\
\text { as additional } \\
\text { SRC-II tests. } \\
\text { Utilities advise } \\
\text { that more: test } \\
\text { burns will estab- } \\
\text { lish markət } \\
\text { stability. }\end{array}$ & $\begin{array}{l}\text { Boiler operators } \\
\text { would like test } \\
\text { burns conducted for } \\
\text { SRC-II, H-coal and } \\
\text { EDS. They believe } \\
\text { test burns are re- } \\
\text { quiled to establish } \\
\text { market suitability. }\end{array}$ & $\begin{array}{l}\text { Manufacturers would } \\
\text { like test burns } \\
\text { conducted in i.7dus- } \\
\text { trial boilers For } \\
\text { all liquefaction } \\
\text { prccesses. They } \\
\text { believe additional } \\
\text { testinc will help } \\
\text { establish market } \\
\text { suitability. }\end{array}$ & $\begin{array}{l}\text { Investment bankers } \\
\text { want to see more } \\
\text { tests. The bankers } \\
\text { want to see all } \\
\text { processes tested } \\
\text { in the commercial } \\
\text { marketplace. }\end{array}$ & $\begin{array}{l}\text { EPA and NIOSH } \\
\text { want more tests } \\
\text { conducted. }\end{array}$ \\
\hline $\begin{array}{l}\text { Technical } \\
\text { development } \\
\text { lead time to } \\
\text { commercializa- } \\
\text { tion }\end{array}$ & $\begin{array}{l}\text { Two are planning } \\
\text { full-scale com- } \\
\text { mercialization, } \\
\text { citing } 5-7 \text { and } \\
\text { lo years as } \\
\text { realistic time- } \\
\text { frames. A third } \\
\text { company has not } \\
\text { yet formulated } \\
\text { plans for a com- } \\
\text { mercial plant. }\end{array}$ & $\begin{array}{l}\text { Most utilities } \\
\text { believe an } 8-10 \\
\text { year leadl time is } \\
\text { realistic. }\end{array}$ & $\begin{array}{l}\text { Boiler operators } \\
\text { believe } 8-10 \text { years } \\
\text { is a realistic lead } \\
\text { time. }\end{array}$ & $\begin{array}{l}\text { Boiler manufac- } \\
\text { turers believe } 8-10 \\
\text { years is a realis- } \\
\text { tic leac time. }\end{array}$ & $\begin{array}{l}\text { Investment bankers } \\
\text { believe at least } \\
10 \text { years are } \\
\text { Fequired to fully } \\
\text { develop technology. }\end{array}$ & $\begin{array}{l}\text { EPA and NIOSH } \\
\text { believe that } \\
8-10 \text { years more } \\
\text { will be required } \\
\text { to fully develop } \\
\text { tecrnology. }\end{array}$ \\
\hline $\begin{array}{l}\text { Technical } \\
\text { coordination } \\
\text { between } \\
\text { industry and } \\
\text { government }\end{array}$ & $\begin{array}{l}\text { All process technol- } \\
\text { ogy companies } \\
\text { believe cooperation } \\
\text { is good and is } \\
\text { necessary to } \\
\text { develop technol- } \\
\text { ogies. }\end{array}$ & $\begin{array}{l}\text { Utilities perceive } \\
\text { industry-jovernment } \\
\text { cooperation as use- } \\
\text { ful Utilities } \\
\text { believe the ex- } \\
\text { change of techni- } \\
\text { cal infornation will } \\
\text { aid process devel- } \\
\text { opment. }\end{array}$ & $\begin{array}{l}\text { Industrial boiler } \\
\text { users believe } \\
\text { technical coopera- } \\
\text { tion is. valuable } \\
\text { but are not con- } \\
\text { vinced it will } \\
\text { speed process } \\
\text { development. }\end{array}$ & $\begin{array}{l}\text { Manufacturers } \\
\text { believe technical } \\
\text { cooperation is } \\
\text { valuable but are } \\
\text { not convinced -t } \\
\text { will speed process } \\
\text { development. }\end{array}$ & $\begin{array}{l}\text { Investment bankers } \\
\text { believe government } \\
\text { involvement in } \\
\text { technical areas } \\
\text { will slow down } \\
\text { technology devel- } \\
\text { opment. }\end{array}$ & $\begin{array}{l}\text { EPA and NIOSH } \\
\text { believe that } \\
\text { irdistry and } \\
\text { government coopera- } \\
\text { tior is useful and } \\
\text { necessary. NIOSH } \\
\text { would like more } \\
\text { industry data on } \\
\text { process technolo- } \\
\text { gies. }\end{array}$ \\
\hline
\end{tabular}


EXHIBIT 6-1 (3)

\begin{tabular}{|c|c|c|c|c|c|c|}
\hline $\begin{array}{l}\text { ISSUE CATEGORY } \\
\text { AND PROBLEM }\end{array}$ & $\begin{array}{l}\text { PROCESS } \\
\text { TECHNOLOGY } \\
\text { COMPANIES }\end{array}$ & |UTILITIES & $\begin{array}{l}\text { INDUSTRIAL } \\
\text { BOILER } \\
\text { USERS }\end{array}$ & $\begin{array}{l}\text { INDUSTRIAL } \\
\text { BOILER } \\
\text { MANUFACTURERS }\end{array}$ & $\begin{array}{l}\text { FI:NANCIAL } \\
\text { COIMUNITY }\end{array}$ & $\begin{array}{l}\text { REGULATORY } \\
\text { AGENCIES }\end{array}$ \\
\hline $\begin{array}{l}\text { 2. MARKET } \\
\text { - Availability } \\
\text { of market } \\
\text { information }\end{array}$ & $\begin{array}{l}\text { One company has } \\
\text { done extensive mar- } \\
\text { ket analyses and is } \\
\text { trying to develop a } \\
\text { utility consortium } \\
\text { to purchase the } \\
\text { products from its } \\
\text { demonstration lique- } \\
\text { faction plant. Two } \\
\text { other company have } \\
\text { not conducted market } \\
\text { studies and have not } \\
\text { yet assimilated in- } \\
\text { formation on the po- } \\
\text { tential boiler fuel } \\
\text { market. }\end{array}$ & $\begin{array}{l}\text { Utilities indicate } \\
\text { they would be a } \\
\text { likely candidate } \\
\text { market for coal } \\
\text { liquefaction } \\
\text { boiler fuels. Some } \\
\text { utilities in the } \\
\text { Northeast are } \\
\text { interested in } \\
\text { forming a consor- } \\
\text { tium to purchase } \\
\text { products from one } \\
\text { of the process } \\
\text { technology } \\
\text { companies. }\end{array}$ & $\begin{array}{l}\text { Industrial boiler } \\
\text { users believe they } \\
\text { would be a likely } \\
\text { candidate market. }\end{array}$ & $\begin{array}{l}\text { Boiler manufac- } \\
\text { turers believe } \\
\text { their customers } \\
\text { are a potential } \\
\text { market for coal } \\
\text { liquefaction } \\
\text { boiler fuels. }\end{array}$ & $\begin{array}{l}\text { Imvestment bankers } \\
\text { dc not have a good } \\
\text { appreciation of } \\
\text { pctential coal } \\
\text { liquefaction boiler } \\
\text { fiel markets. }\end{array}$ & $\begin{array}{l}\text { EPA and NIOSH have } \\
\text { little information } \\
\text { on the potential } \\
\text { boiler fuel } \\
\text { market. }\end{array}$ \\
\hline $\begin{array}{l}\text { - Sufficiency } \\
\text { of market } \\
\text { demand }\end{array}$ & $\begin{array}{l}\text { One process technol- } \\
\text { ogy company is } \\
\text { confident that mar- } \\
\text { ket demands for } \\
\text { boiler fuels are } \\
\text { sufficient to pro- } \\
\text { ceed to commer- } \\
\text { cialization of } \\
\text { boiler fuel mode } \\
\text { technology. } \\
\text { One process technol- } \\
\text { ogy company be- } \\
\text { lieves that market } \\
\text { demand for coal } \\
\text { liquefaction prod- } \\
\text { ucts is for trans- } \\
\text { portation fuels; } \\
\text { but in short term, } \\
\text { the market is for } \\
\text { boiler fuels. } \\
\text { One process technol- } \\
\text { ogy compány is not } \\
\text { sure what the mar- } \\
\text { ket demand for coal } \\
\text { liquefaction prod- } \\
\text { ucts will be and } \\
\text { is taking a "wait } \\
\text { and see" attitude } \\
\text { before deciding how } \\
\text { to configure its } \\
\text { frocess. }\end{array}$ & $\begin{array}{l}\text { Utilities believe } \\
\text { they would create } \\
\text { sufficient demand } \\
\text { for coal liquefac- } \\
\text { tion products The } \\
\text { utilities in the } \\
\text { Northeast are } \\
\text { willing to pay a } \\
\text { premium to obtain } \\
\text { coal liquefaction } \\
\text { boiler fuels } \\
\text { because they are } \\
\text { interested in secu- } \\
\text { rity and stability } \\
\text { of supply. }\end{array}$ & $\begin{array}{l}\text { Industrial toiler } \\
\text { owners belifve they } \\
\text { would create: a } \\
\text { demand for boiler } \\
\text { fuels, but are not } \\
\text { sure about how } \\
\text { much they would } \\
\text { buy. }\end{array}$ & $\begin{array}{l}\text { Boiler manufac- } \\
\text { turers perceive } \\
\text { their customers } \\
\text { as creating a } \\
\text { market for } \\
\text { boiler fuels. }\end{array}$ & $\begin{array}{l}\text { Irvestment bankers } \\
\text { do not have an } \\
\text { appreciation of } \\
\text { potential demand } \\
\text { for coal lique- } \\
\text { faction boiler } \\
\text { faels. Investment } \\
\text { bankers advise } \\
\text { s=rong market } \\
\text { demand must be } \\
\text { e.stablished to } \\
\text { enhance further } \\
\text { təchnology } \\
\text { development. }\end{array}$ & $\begin{array}{l}\text { EPA and NIOSH do } \\
\text { not believe that } \\
\text { market demand has } \\
\text { been established. }\end{array}$ \\
\hline
\end{tabular}


EXHIBIT 6-1 (4)

\begin{tabular}{|c|c|c|c|c|c|c|}
\hline \begin{tabular}{|l|} 
ISSUE CATEGORY \\
AND PROBLEM \\
\end{tabular} & $\begin{array}{l}\text { PROCESS } \\
\text { TECHNOLOGY } \\
\text { COMPANIES }\end{array}$ & UTILITIZS & $\begin{array}{l}\text { INDUSTRIAL } \\
\text { BCILER } \\
\text { USERS }\end{array}$ & $\begin{array}{l}\text { INDUSTRIAL } \\
\text { BCIIER. } \\
\text { MANUFACTURERS }\end{array}$ & $\begin{array}{l}\text { FINANCIAL } \\
\text { COMMUNITY }\end{array}$ & $\begin{array}{l}\text { REGULATORY } \\
\text { AGENCIES }\end{array}$ \\
\hline $\begin{array}{l}\text { Determination of } \\
\text { future need for } \\
\text { coal liquefac- } \\
\text { tion facilities }\end{array}$ & $\begin{array}{l}\text { Two process technol- } \\
\text { ology companies be- } \\
\text { lieve that a future } \\
\text { need for coal lique- } \\
\text { faction facilities } \\
\text { has been estab- } \\
\text { lished. }\end{array}$ & $\begin{array}{l}\text { Utilities in the } \\
\text { Northeast believe } \\
\text { that a need exists } \\
\text { for coal liquefac- } \\
\text { tion facilities. }\end{array}$ & $\begin{array}{l}\text { Boiler owners be- } \\
\text { lieve that a need } \\
\text { would exist for } \\
\text { coal liquefaction } \\
\text { facilities if the } \\
\text { ful price was } \\
\text { competitive. }\end{array}$ & $\begin{array}{l}\text { Boiler manufac- } \\
\text { turers believe that } \\
\text { a need would exist } \\
\text { for coal liquefac- } \\
\text { tion if the fuel } \\
\text { price was competi- } \\
\text { tive. }\end{array}$ & $\begin{array}{l}\text { Investment bankers } \\
\text { do not believe that } \\
\text { a need las been es- } \\
\text { tablished for coal } \\
\text { liquefaction facil- } \\
\text { ities. }\end{array}$ & $\begin{array}{l}\text { EPA and NIOSH do not } \\
\text { believe that a need } \\
\text { has been established } \\
\text { for coal liquefac- } \\
\text { tion facilities. }\end{array}$ \\
\hline $\begin{array}{l}-\operatorname{Satisfactory}_{\text {price }} \\
\text { prict }\end{array}$ & $\begin{array}{l}\text { Coal-derived } \\
\text { liquids will com- } \\
\text { pete with petro- } \\
\text { leum derived } \\
\text { fuels when the } \\
\text { demonstration/ } \\
\text { pioneer plants } \\
\text { are completed. }\end{array}$ & $\begin{array}{l}\text { Utilities believe } \\
\text { that a sati.sfactory } \\
\text { price has not been } \\
\text { established, al- } \\
\text { though, some North- } \\
\text { east utilities are } \\
\text { willing to pay a } \\
\text { premium for supply } \\
\text { security. }\end{array}$ & $\begin{array}{l}\text { Boiler owners be- } \\
\text { lieve that a satis- } \\
\text { factory price has } \\
\text { not been estab- } \\
\text { lished. }\end{array}$ & $\begin{array}{l}\text { Boiler manufac- } \\
\text { turers believe that } \\
\text { a satisfactory price } \\
\text { has not yet been } \\
\text { established. }\end{array}$ & $\begin{array}{l}\text { Investment bankers } \\
\text { be ieve that the } \\
\text { price of coallique- } \\
\text { faction boiler } \\
\text { fuels will not be- } \\
\text { come conpetitive } \\
\text { for } 8-1 \text { - years. }\end{array}$ & $\begin{array}{l}\text { EPA and NIOSH do not } \\
\text { believe that a satis- } \\
\text { factory price has } \\
\text { been established. }\end{array}$ \\
\hline $\begin{array}{l}\text { Fuel availabil- } \\
\text { ity }\end{array}$ & $\begin{array}{l}\text { Process technology } \\
\text { companies do not } \\
\text { know with certainty } \\
\text { when fuel will be } \\
\text { available but pro- } \\
\text { ject a } 6-10 \text { year } \\
\text { lead time for fuel } \\
\text { to be available in } \\
\text { commercial quanti- } \\
\text { ties. }\end{array}$ & $\begin{array}{l}\text { Utilities do not } \\
\text { know when fuel will } \\
\text { be available. }\end{array}$ & $\begin{array}{l}\text { Boiler owners do } \\
\text { not know when fuel } \\
\text { will be available. }\end{array}$ & $\begin{array}{l}\text { Boiler manufac- } \\
\text { turers do not know } \\
\text { when fuel will be } \\
\text { available. }\end{array}$ & $\begin{array}{l}\text { Investment bankers } \\
\text { do not know when } \\
\text { fuel will be avail- } \\
\text { able but believe } \\
\text { lead time is at } \\
\text { least } 10 \text { years. }\end{array}$ & $\begin{array}{l}\text { EPA and NIOSH do not } \\
\text { know when fuel will } \\
\text { be available. }\end{array}$ \\
\hline $\begin{array}{l}\text { 3. ENVIRONMENTAL } \\
\text { CONCERNS }\end{array}$ & $\begin{array}{l}\text { Process } \\
\text { companies do not } \\
\text { believe environ- } \\
\text { mental hazards will } \\
\text { be "show stoppers." } \\
\text { They believe that } \\
\text { environmental haz- } \\
\text { ards are manage- } \\
\text { able. }\end{array}$ & $\begin{array}{l}\text { Utilities do not } \\
\text { believe that en- } \\
\text { vironmental hazards } \\
\text { will be "shcw stop- } \\
\text { pers." }\end{array}$ & $\begin{array}{l}\text { Bo:ler owners do } \\
\text { not believe that } \\
\text { environmental haz- } \\
\text { ards will be "show } \\
\text { stoppers." - }\end{array}$ & $\begin{array}{l}\text { Bo:ler manufac- } \\
\text { turers do not be- } \\
\text { lieve that environ- } \\
\text { mental hazards will } \\
\text { be "show stoppers." }\end{array}$ & $\begin{array}{l}\text { Investment bankers } \\
\text { are not familiar } \\
\text { with the potential } \\
\text { environmental haz- } \\
\text { ards. They be- } \\
\text { lieve that if EPA } \\
\text { gets invlved, the } \\
\text { projects will } \\
\text { "never get moving." }\end{array}$ & $\begin{array}{l}\text { EFA and NIOSH have } \\
\text { conducted environ- } \\
\text { mental research and } \\
\text { have a continuous re- } \\
\text { search ef fort under-. } \\
\text { way. EPA believes } \\
\text { that current known } \\
\text { environmental hazards } \\
\text { will not prevent } \\
\text { commercialization of } \\
\text { coal liquefaction } \\
\text { technology. }\end{array}$ \\
\hline $\begin{array}{l}\text { - Regulatory } \\
\text { compliance }\end{array}$ & $\begin{array}{l}\text { Process technology } \\
\text { companies fully ex- } \\
\text { pect to comply with } \\
\text { current regula- } \\
\text { tions. }\end{array}$ & $\begin{array}{l}\text { Utilities believe } \\
\text { that regulatory com- } \\
\text { pliance will not be } \\
\text { a problem. }\end{array}$ & $\begin{array}{l}\text { Boiler owners be- } \\
\text { lieve that regula- } \\
\text { tory compliance will } \\
\text { not be a problem. }\end{array}$ & $\begin{array}{l}\text { Boiler manufac- } \\
\text { turers do not be- } \\
\text { lieve that regula- } \\
\text { tory compliance will } \\
\text { be a problem. }\end{array}$ & $\begin{array}{l}\text { Investme.lt bankers } \\
\text { believe =hat the } \\
\text { environmental issue } \\
\text { could "kill" a coal } \\
\text { liquefac-ion indus- } \\
\text { try in the early } \\
\text { stages. Two large } \\
\text { banks ci ied the }\end{array}$ & $\begin{array}{l}\text { The EPA believes } \\
\text { that with strict } \\
\text { workplace hygiene } \\
\text { standards, regulatory } \\
\text { compliance should not } \\
\text { be a problem. EPA } \\
\text { believes that re- } \\
\text { laxation of new source }\end{array}$ \\
\hline
\end{tabular}


EXHIBIT 6-1 (5)

\begin{tabular}{|c|c|c|c|c|c|c|}
\hline$\underbrace{\text { ACTORS }}_{\substack{\text { ISSUE CATEGORY } \\
\text { AND PROBLEM }}}$ & $\begin{array}{l}\text { PROCFISS } \\
\text { TECFNOLOGY } \\
\text { COMFANIES }\end{array}$ & UTILITIES & $\begin{array}{l}\text { INDUSTRIAL } \\
\text { BOILER } \\
\text { USERS }\end{array}$ & $\begin{array}{l}\text { INDUSTRIAL } \\
\text { BOILER } \\
\text { MANUFACTURERS }\end{array}$ & $\begin{array}{l}\text { FINANCIAL } \\
\text { COMMUNITY }\end{array}$ & $\begin{array}{l}\text { REGULATORY } \\
\text { AGENCIES }\end{array}$ \\
\hline $\begin{array}{l}\text { Regulato }=y \\
\text { compliance } \\
\text { (cont'd) }\end{array}$ & & 一 & & & $\begin{array}{l}\text { Three Mile Island } \\
\text { incident as an ex- } \\
\text { ample of "environ- } \\
\text { mental overkill." }\end{array}$ & $\begin{array}{l}\text { performance standards } \\
\text { for new technologies } \\
\text { may be necessary to } \\
\text { encourage process } \\
\text { development. EPA } \\
\text { has already given } \\
\text { some signals that it } \\
\text { is willing to do this. } \\
\text { (See NSPS in June ll, } \\
\text { l979 F.R.) }\end{array}$ \\
\hline $\begin{array}{l}\text { Maintenance of } \\
\text { environmental } \\
\text { quality }\end{array}$ & $\begin{array}{l}\text { Process technology } \\
\text { companies do not } \\
\text { believe a problem } \\
\text { will exist. }\end{array}$ & $\begin{array}{l}\text { Utilities do not see } \\
\text { a problem. }\end{array}$ & $\begin{array}{l}\text { Boiler owners do not } \\
\text { see a problem. }\end{array}$ & $\begin{array}{l}\text { Boiler manufac- } \\
\text { turers do not see a } \\
\text { problem. }\end{array}$ & $\begin{array}{l}\text { Investment bankers } \\
\text { do not believe a } \\
\text { problem will exist. }\end{array}$ & $\begin{array}{l}\text { EPA/NIOSH believe a } \\
\text { problem could exist } \\
\text { without adequate safe- } \\
\text { guards. }\end{array}$ \\
\hline $\begin{array}{l}\text { Maintenarce of } \\
\text { health ard } \\
\text { safety }\end{array}$ & $\begin{array}{l}\text { Companies do not } \\
\text { believe a problem } \\
\text { will exist with ade- } \\
\text { quate safeguards. }\end{array}$ & $\begin{array}{l}\text { Utilities do not } \\
\text { believe a problem } \\
\text { will exist with ade- } \\
\text { quate safeguards. }\end{array}$ & $\begin{array}{l}\text { Boiler owners do no: } \\
\text { believe a problem } \\
\text { will exist with ade- } \\
\text { quate safeguards. }\end{array}$ & $\begin{array}{l}\text { Boiler manufac- } \\
\text { turers do not be- } \\
\text { lieve a problem } \\
\text { will exist with ade- } \\
\text { quate safeguards. }\end{array}$ & $\begin{array}{l}\text { Investment bankers } \\
\text { do not believe a } \\
\text { problem will exist } \\
\text { with adequate safe- } \\
\text { guards. }\end{array}$ & $\begin{array}{l}\text { EPA and NIOSH believe } \\
\text { that strict worker } \\
\text { handling safeguards } \\
\text { will be required to } \\
\text { reduce health and } \\
\text { safety risks. }\end{array}$ \\
\hline 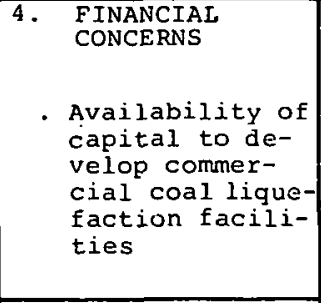 & $\begin{array}{l}\text { Technological risk } \\
\text { may require invest- } \\
\text { ment tax credits } \\
\text { and accelerated de- } \\
\text { preciation to en- } \\
\text { hance the viability. } \\
\text { of the first com- } \\
\text { mercial plants. }\end{array}$ & $\begin{array}{l}\text { Utilities believe } \\
\text { commercialization } \\
\text { will require govern- } \\
\text { ment assistaice in } \\
\text { providing develop- } \\
\text { ment funds. }\end{array}$ & $\begin{array}{l}\text { Boiler owners be- } \\
\text { lieve commerciali- } \\
\text { zation will require } \\
\text { government assis- } \\
\text { tance in providing } \\
\text { development funds. }\end{array}$ & $\begin{array}{l}\text { Manufacturers be- } \\
\text { lieve commerciali- } \\
\text { zation will not take } \\
\text { place without gov- } \\
\text { ernment funding. }\end{array}$ & $\begin{array}{l}\text { Investment bankers } \\
\text { will not raise } \\
\text { funds until eco- } \\
\text { nomics are proven. } \\
\text { They believe gov- } \\
\text { ernment involve- } \\
\text { ment in funding } \\
\text { will sour outlook } \\
\text { for commercial } \\
\text { success. }\end{array}$ & $\begin{array}{l}\text { EPA does not believe } \\
\text { private funds are } \\
\text { available and believes } \\
\text { government must con- } \\
\text { tribute funds to } \\
\text { make the technology } \\
\text { ready for commer- } \\
\text { cialization. }\end{array}$ \\
\hline $\begin{array}{l}\text { Prices for coal } \\
\text { liquefaction } \\
\text { boiler fuels }\end{array}$ & $\begin{array}{l}\text { Prices for coal- } \\
\text { derived liquids } \\
\text { should be compet- } \\
\text { itive with petro- } \\
\text { leum-derived fuels } \\
\text { at the time com- } \\
\text { mercial plants } \\
\text { come on stream. }\end{array}$ & $\begin{array}{l}\text { Utilities believe } \\
\text { prices not competi- } \\
\text { tive, but, some } \\
\text { Northeast utilities } \\
\text { will pay a premium } \\
\text { for supply stabil- } \\
\text { ity. }\end{array}$ & $\begin{array}{l}\text { Boiler owners be- } \\
\text { lieve that prices } \\
\text { are not competitive } \\
\text { with current com- } \\
\text { mercial products. }\end{array}$ & $\begin{array}{l}\text { Boiler manufac- } \\
\text { turers do not be- } \\
\text { lieve that prices } \\
\text { are competitive } \\
\text { with current con- } \\
\text { mercial products. }\end{array}$ & $\begin{array}{l}\text { Investment bankers } \\
\text { believe tr:at prices } \\
\text { are not competitive } \\
\text { with current com- } \\
\text { mercial products } \\
\text { and believe com- } \\
\text { mercialization will } \\
\text { not take place un- } \\
\text { til economics im- } \\
\text { prove. }\end{array}$ & $\begin{array}{l}\text { EPA believes that prices } \\
\text { are not competitive } \\
\text { with commercial pro } \\
\text { ucts. }\end{array}$ \\
\hline
\end{tabular}


boiler fuels are not convinced of the potential economic advantage nor are they inclined to believe that an economic advantage will be established in five to ten years.

The total size of the boiler fuel market must be sufficiently large to influence the process development companies to take the technology into commercialization. There is some desparity among the views of the direct coal liquefaction technology companies. One of the companies appears ready to go now into the boiler fuel mode for its process. One company already believes that the market will be for transportation fuels, and one company is taking a "waitand-see" attitude before deciding how to configure its process technology. This shows the apparent uncertainty prevalent among the process technology companies regarding the configuration of their respective technologies to meet expected markets.

Private capital may not be available to finance the coal liquefaction plants, and this will be a major barrier for the process technology companies to eventually develop a market. Major uncertainties associated with coal liquefaction products make investment bankers skeptical. Bankers are not optimistic about long-term market potential. Additionally, there are transportation and handling questions yet to be resolved, regulatory policies to be established, government fuels allocation decisions to be made, and uncertain political factors to be answered. Investment bankers perceive coal liquefaction as too risky and too costly for commercial development at this time.

3. END-MARKET PERCEPTIONS AND BUYER BEHAVIOR WILL DICTATE THE SPEED OF' COAL LIQUEFACTION COMMERCIAL DEVELOPMENT

Market behavior in the industrial fuel market is influenced by the price of the petroleum product under con. sideration. Industrial boiler fuel owners make their "buy" decision based on their perception of the least expensive fuel available that provides equivalent heating value to the next incremental alternative. They do not see a price advantage to coal liquefaction boiler fuels at the current time.

Utility purchasing behavior is influenced by life cycle economic considerations and fuel price. Utilities desire security and stability of supply over the long term. Utilities do not perceive coal liquids as being economically attractive on cost grounds at the present time, but some utilities indicated a willingness to pay a premium over the cost of an imported barrel for the security of coal liquid 
supply. Utilities believe that costs could be "rolled in" to their current fuel cost base rather than costing on an incremental basis. An unresolved issue in this area is that state and regulatory commissions have not yet addressed the rate structure for coal liquids utilization.

Industrial marketplace representatives generally believe that efforts at coal liquefaction commercialization to produce boiler fuels may fail because the necessary economic considerations will not be taken into account by the Federal Government.

The three most important factors that are dominant concerning end-market perceptions are (1) a lack of sufficient information about the technologies and their respective products, (2) a preference for costs that are competitive with petroleum fuels, and (3) the uncertainties surrounding government policies. No "buy" decisions will be made until the Government's fuels allocation policy stabilizes, and there is an interpretation issued for industrial and utility managements on how the President's July 15, 1979 energy initiatives will affect them.

4. SOCIAL, POLITICAL, LEGAL, AND REGULATORY ISSUES MAY CONSTRAIN DEVELOPMENT OF A COAL LIQUEFACTION BOILER FUELS MARKET

(1) Potential Societal Concerns May Inhibit Market Growth

There is widespread belief that special interest groups will use the hearing and litigation process to delay Iiquefaction plant siting and, thus, foreclose any possibility of any market development. There is also widespread belief that public interest groups will not allow some "new" type of fuel in their "backyard." Some interviewees professed the feeling that the emotional environment might be similar to that which existed in the early 1960 s when nuclear plants were being sited.

(2) Potential Political Factors Will Affect Market Development for Coal Liquefaction : Products

Two areas will deserve attention-pending legis- lation and executive branch initiatives:

- Pending Legislation. There are various bills recently introduced in the Congress that will 
influence coal liquids market development. Two major pieces of legislation are:

- Energy Supply Act, which sets forth a national program for the full development of the United States' total energy supply, including the development of synthetic fuels from coal.

- Amendments to the Defense Production Act of 1950, which provideo for the purchase of synthetic fuels and synthetic chemical feedstocks by the Federal Government.

A more complete description of these bills can be found in section 7 .

Although these bills appear to assist coal liquids market development, the industrial marketplace perceives that the current political climate will delay ultimate commercialization. Further, it believes no market development will take place until the pending legislation is enacted, and a major emphasis is placed on developing an attractive economic climate.

- Executive Branch Initiatives. The recent Presidential energy initiative relative to coal liquids was discussed earlier in this report. The Executive Branch policy is to convert oil-fired plants to coal. There are questions yet to be answered concerning where the market for coal liquids would be given the President's initiative. Discussions held with marketplace representatives indicate that technology commercialization and subsequent market development will be delayed pending resolution of the recently announced initiatives:

- The Energy Mobilization Board will be authorized to designate certain nonnuclear facilities, including coal liquefaction plants, as critical to achieving the import reduction goals. 
- The Energy Mobilization Board will be authorized to waive procedural requirements of Federal, state, or local laws to expedite the development of designated facilities:

- Although these procedures may ultimately aid the commercialization of coal liquefaction technologies, many political issues will need to be resolved before the Board is established.

(3) The Implementation of the Powerplant and Industrial Fuel Use Act of 1978 will Have an Impact on the Development of a Market for coal Liquefaction Boiler Fuels

The provisions of this Act have not yet been implemented in final form; however, the basic purpose of switching existing boilers away from petroleum fuels to coal or fuels derived from coal would appear to have a positive influence on the development of coal liquids markets.

Although the Fuel Use Act (See Chaptcr 5) grants exemptions for coal conversion for boiler owners certifying their intent to use synthetic fuels, industry is likely to await the final regulations before deciding whether to consider synthetic fuels.

(4) Regulatory Issues May Impede Market Development

Numerous companies cited the unpredictable nature of DOE and EPA regulations as being major barriers to coal liquids market development:

- Many marketplace representatives advised that there is a lack of cooperation and coordination between the EPA and DOE on coal liquefaction development. Companies believe that closer cooperation must be developed to get coal liquefaction technology to commercialization readiness.

- Investment bankers indicated that uncertain regulatory policies will be a major barrier to commercialization due to the increased risk in new investments and reduced incentives to shift to new technologies. 
5. MARKET SYSTEM BARRIERS WILL HAVE TO BE OVERCOME TO ALLOW FOR FULL-SCALE MARKET DEVELOPMENT

Exhibit 6-2 shows the components of the industrial/ market system involved in the commercialization of coal liquids technology. Market development will take place if the following elements exist:

- There is a willingness on the part of each of the individual components of the industrial, utility, and Governmental groups to try a new technology and take the corresponding risks.

- The costs of moving the technology from conception to commercialization to production of product for the end-use markets are competitive with alternative energy forms.

- The traditional system is reoriented to accommodate new technology.

- A cooperative environment exists between the Government and the industrial sector to provide a healthy climate for commercialization.

6. LABOR UNION CONCERNS CENTER ON THO ISSUES-PERCEIVED INCREASES IN ADDITIONAL EMPLOYMENT OPPORTUNITIES CONCOMITANT WITH THE COMMERCIALIZATION OF A SYNTHETIC FUELS INDUSTRY AND THE HEALTH AND SAFETY FOR PEOPLE TORKING IN THE LIQUEFACTION PLANTS AND THOSE INVOLVED IN THE PRODUCT MARKETING CHANNELS

Labor unions believe that an emerging syn-fuels industry will provide more jobs and that process commercialization should take place as rapidly as possible. Unions believe more skilled jobs will be available for liquefaction plant construction and the development of associated marketing infrastructure will create additional skilled and semiskilled jobs. A major question, however, that needs to be addressed is whether or not sufficient skilled labor will be available to assist in the development of the industry.

The AFL-CIO was somewhat familiar with the potential environmental risks of coal liquefaction products and would like additional information on potential health hazards. Potential health hazards were not perceived as being barriers to marketability as it is believed that sufficient safeguards will be developed. The AFL-CIO is initiating a research program to follow the development of a synthetic fuels 


\section{EXHIBIT 6-2}

Components of the Industrial Market System Involved in the Commercialization of Direct Coal Liquefaction Boiler Fuels

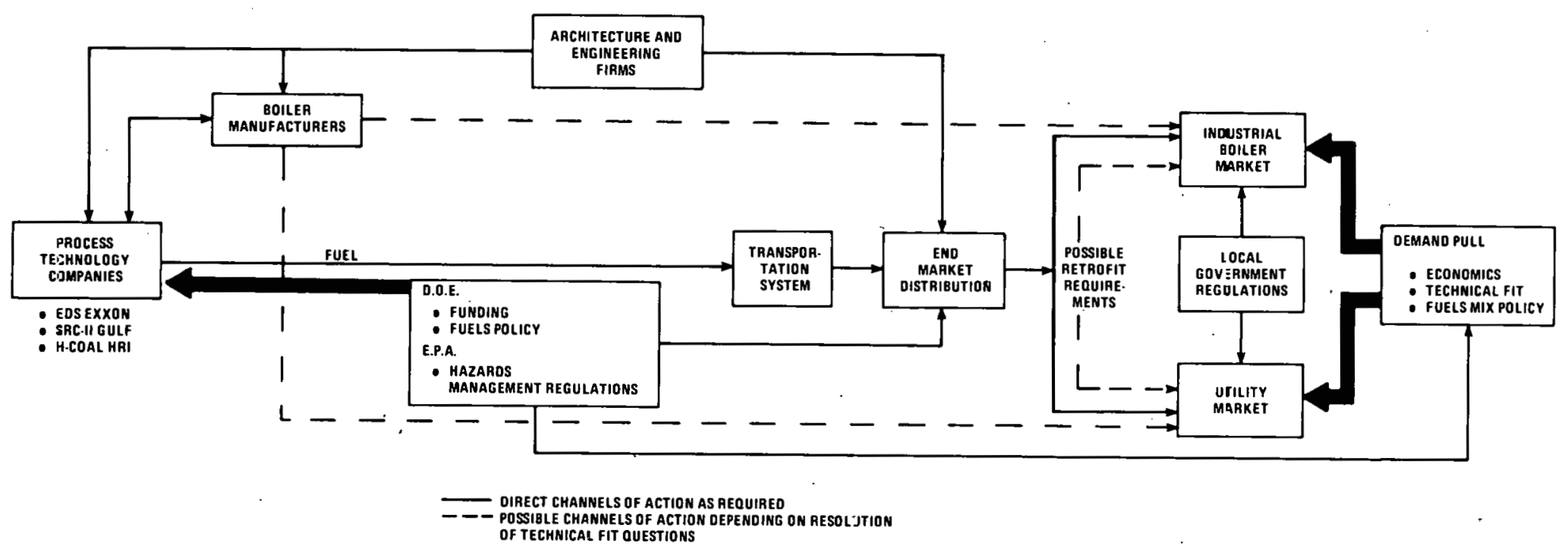


industry. The focus will be on health and safety requirements and on lobbying in the Executive Branch and in the Congress to ensure that adequate health and safety precautions will be established.

7. PENDING LEGISLATION WILL AFFECT COAL LIQUIDS MARKET DEVELOPMENT

There are two major measures recently introduced in the Congress and are currently in Committees that address the future markets for coal liquefaction production. Senator Jackson introduced a bill (S.1308) entitled "Energy Supply Act" to set forth a national program for the full development of the United States' total energy supply, including the development of synthethic fuels from coal. Representative Moorehead introduced a bill entitled "Amendments to the Defense Production Act of 1950" to extend the authority granted by the Act and to provide for the purchase of synthetic fuels and synthetic chemical feedstocks by the Federal Government. Each of these bills will be discussed separátely.

(1) The Energy Supply Act (S-1308)

The main purposes of this act relating to coal liquefaction are to provide the Secretary of Energy with the authority to assist in expediting and in financing of projects which will increase domestic energy supplies, including coal liquefaction projects and to provide for the conversion of certain commercial and industrial facilities from petroleum to coal. Staff members of the Committee on Energy and Natural Resources indicate that the intent of the legislation is to cover coal-derived liquids also. Coal is defined in the Act as anthracite, bituminous, lignite, and any fuel derived from coal.

The Energy Supply Act provides for a prompt, simplified, and expeditious process for Federal approval of non-nuclear energy facilities that are determined to be in the national interest, which among other criteria, would mean facilities which would reduce the United States' dependence on imported petroleum. The Act also provides the Department of Energy with energy project authorizations. Effective for fiscal year 1980 (October 1, 1979 - September 30, 1980), and for subsequent fiscal years, $\$ 700$ million would be authorized for the development of the SRC-II process. This authorization 
is based on January 1979 cost data developed by Committee staff and may vary from time to time, depending on escalations in construction costs during the development of the project.

A price incentive provision is incorporated in the Act which provides that the Government will pay to the seller the difference between the contract price for the syn-fuel and the "marketplace" price for the syn-fuel as determined by the secretary of Energy. This provision may enhance the economic attractiveness of synthetic fuel development.

The Moorehead Bill (H.R. 3930)

The main provision of the Moorehead Bill relating to the development and marketability of coal liquefaction produots is to provide a national production goal of at least 2 million barrels per day crude oil, equivalent of synthetic fuels and synthetic chemical feedstocks by 1990. The House Banking Committee has reported out a less ambitious proposal to develop 500,000 barrels of synthetic fuel productive capacity by 1984 .

The bill also provides the President of the United States with the authority to require the use of synthetic fuels and chemical feedstocks in any case in which the President deems it practicable and necessary to meet the national defense needs of the United States.

The bill provides that a government market for synthetic fuels and synthetic chemical feedstocks will be established and has provisions to encourage the development and production of synthetic fuels and.synthetic chemical feedstocks for national defense purpose:

Lastly, the bill establishes a ceiling of 100,000 barrels per day on the amount that any one contractor can sell to the Government.

As previously discussed in Chapter 3, the Federal Government would not be a large boiler fuel market. This has significant implications on the configuration of the process technologies. 
(3) Other Synthetic Fuel Bills Have Been Introduced in the 96 th Congress

These bills relating to the commercialization of coal liquefaction technology are described briefly in the following paragraphs:

- H.R. 602 amends the Defense Production Act of 1950 to include synthetic fuels which may be used as fuels under Title III. Introduced by Rep. William Moorehead (D-Penna.) on January 15, 1979.

- H.R. 4349 amends the Defense Production Act of 1950 to extend the authority granted by such Act and to provide for the purchase of synthetic fuels and synthetic chemical feedstocks. Introduced by Rep. Moorehead on June 6, 1979.

H.R. 4568 extends authority granted by the Defense Product Act and provides for the purchase of synthetic fuels and synthetic chemical feedstocks. Introduced by Rep. Moorehead on June 21, 1979.

Note: Rep. Moorehead introduced four bills. H.R. 3930 is a clean bill reported by the House Banking, Finance, and Urban Affairs Committee in lieu of the original measure, H.R. 602 . The other two bilis, H.R. 4349 and H.R. 4568, are identical to the Moorehead Bill that was approved by the House. Thiey were introduced to facilitate the large lists of co-sponsors.

- H.R. 2428 amends the Internal Revenue Code of $\overline{1954}$ to provide for the amortization of coal conversion facilities based on a 12-month period and to establish a price support program for synthetic fuels produced from coal at such facilities. Introduced by Rep. John Duncan (R-Tenn.) on February 26, 1979.

- H.R. 4336 amends the Defense Production Act of 1950 to extend the authority granted by such Act and to provide for the purchase of synthetic fuels and synthetic chemical feedstocks. Introduced by Rep. Tom Bevill (D-Ala.) on June $6,1979$. 
- H.R. 4355 amends the Defense Production Act of 1950 to extend the authority granted by such Act and to provide for the purchase of synthetic fuels and synthetic chemical feedstocks. Introduced by Rep. Fernand St. Germain (D-RI) on June 6, 1979.

- H.R. 4474 amends the Energy Policy and Conservation Act to promote commerce in synthetic fuels. Introduced by Rep. John Dingell (D-Mich.) on June 14, 1979.

- H.R. 4484, National Energy Self-Sufficiency Act of 1979, imposes a duty on imported crude oil and would use the proceeds of such duty to make loans for the construction of facili-. ties for the production of synthetic fossil fuels. Introduced by Rep. Don Bailey (D-Penna.) on June 15, 1979 .

H.R. 4499 sets forth a national program for full development of energy supply. Introduced by Rep. Dingell on June 15, 1979.

H.R. 4500 sets forth a national program for the full development of energy supply. Introduced by Rep. Dingell on June 15, 1979.

- H.R. 4514 amend Title III of the comprehensive Employment Training Act to provide for the assessment of manpower needs for the full development of domestic energy resources. Introduced by Rep. Carl Perkins (D-Ky.)

- H.R. 4588, Synthetic Fuels Production Act of 1979, oreates a government corporation that will provide financing and other economic aid to those sectors which are important for development of domestic energy sources and for the conservation of energy and attainment of energy independence. The bill would also expedite regulatory procedures which affect energy development. Introduced by Reps. Thomas Luken (D-Ohio) and Cecil Heftel (DHI) on June $22,1979$. 
H.R. 4594 requires oil refineries to sell a minimum percentage of their production in synthetic fuels and provides certain tax incentives for synthetic fuels. Introduced by Rep. Robert Walker (R-Penna.) on

June 22,1979 .

H.R. 4474, H.R. 4499, and H.R. 4500. These three measures were introduced by Rep. John Dingell, the Chairman of the Energy and Power Subcommittee of the House Interstate and Foreign Commerce Committee. Only two of the three measures are being considered, however. The two bills, H.R. 4499 and H.R. 4500 have been referred as a package to eight committees, including the House Energy and Power subcommittee which held hearings on June 22 and 25. The provisions of a third bill, H.R. 4474, which dealt exclusively with syn-fuels were incorporated in one of the other two measures, H.R. 4499, Title I. Rep. Dingell's syn-fuel proposals are similar to Rep. Moorehead's with one important distinction. Rep. Dingell wants the syn-fuels legislation to be consistent with applicable environmental, conservation, and fuel conservation. policies of the United States. Mr. Dingell's bills are also considered to be the companion measures to Sen. Henry Jackson's Energy Supply Act (S.1308).

H.R. 2428, H.R. 4346, and H.R. 4355. These three measures were introduced by Reps. John Duncan, Tom Bevill, and Fernand St. Germain, respectively. The three bills are in committee where no action is contemplated.

H.R. 4514, amends the Comprehensive Employment Training Act and creates a quasigovernmental authority that could issue up to $\$ 200$ million in bonds to finance synthetic fuels development. The authority would also be charged with the production of five million barrels a day of synthetic fuel. A Subcommittee of the Education and Labor Subcommittee has approved this bill but it is unlikely that this measure will reach the House Floo'r. 
- S. 1377, Synthetic Fuels Production Act of 1979, creates a government corporation that will provide financing and other economic aid to those sectors which are important for development of domestic energy sources, the conservation of energy and attainment of energy independence; to expedite regulatory procedures which affect energy development. Introduced by Senators Peter Domenici ( $R-N M)$ and Bennett Johnston (D-LA) on June 19, 1979. 


\section{CHAPTER 7 \\ COSTS OF DISTRIBUTION AND HANDLING \\ COAL LIQUEFACTION BOILER FUELS}


CHAPTER 7

COSTS OF DISTRIBUTION AND HANDLING

COAL LIQUEFACTION BOILER FUELS

Booz, Allen was asked to identify the costs associated with distributing coal liquefaction products from liquefaction plants to potential consumption points. The transportation assessment was performed based on informed judgments in five areas:

- Existing transportation infrastructure from liquefaction plant to potential consumption points

- Relative economics of transporation modes

- Potential environmental impacts

- Safety standards

- Handling requirements.

The evaluation was done in the context that coal liquefaction products may be utilized in lieu of residual fuel oil, and the infrastructure used to market coal liquids may be the same as that for residual. Booz, Allen reviewed possible coal liquefaction plant sites and proceeded to identify the transportation system necessary to transport the coal liquids to likely candidate markets. This construct proved useful in identifying potential barriers to marketability and in identifying areas that will require additional research and evaluation before informed decisions can be made. A qualitative evaluation of potential market barriers on four transporation modes-pipeline, barge, rail, and truck-is shown in Exhibit 7-1. As indicated, there are barriers associated with each mode of transporting coal

liquids. Each mode has its own associated barrier which must be resolved before full-scale coal liquid production can take place. Issues pertaining to the market barriers will be addressed separately. 
EXHIBIT 7-1

Evaluation of Transportation Market Barriers

for Coal Liquids

\begin{tabular}{|c|c|c|c|c|c|c|c|c|}
\hline \multirow{3}{*}{$\begin{array}{c}\text { Transportation } \\
\text { Mode }\end{array}$} & \multicolumn{7}{|c|}{ Potential Market Barriers } & \multirow{3}{*}{ Overall } \\
\hline & \multicolumn{4}{|c|}{$\begin{array}{c}\text { Existing } \\
\text { Infrastructure }\end{array}$} & \multirow[t]{2}{*}{ Economics } & \multirow[t]{2}{*}{ Environmental } & \multirow[t]{2}{*}{ Safe $\pm y$} & \\
\hline & 1 & 2 & 3 & 4 & & & & \\
\hline Pipeline & 0 & $\mathbf{0}$ & $\bullet$ & 0 & $0-\theta^{*}$ & 0 & 0 & $0-\theta^{*}$ \\
\hline Barge & $\theta$ & $\mathbf{0}$ & - & 0 & 0 & $\bullet$ & $\theta$ & $\theta$ \\
\hline Rail & 0 & 0 & $\theta$ & $\theta$ & $\bullet$ & $\boldsymbol{\theta}$ & 0 & $\theta$ \\
\hline Truck & 0 & $\theta$ & $\theta$ & $\theta$ & $\bullet$ & $\theta$ & $\theta$ & $\mathbf{0}$ \\
\hline
\end{tabular}

* Depends on economics of constructing a new pipeline system specifically for coal 1 iquefaction products.

Legend:

- Mày pose a significant barrier

- May pose a barrier

0 Does not pose a barrier

1 = A coal liquefaction plant in either Kentucky or West Virginia and candidate markets in the Northeast and Atlantic regions

$2=A$ coal liquefaction plant in Southern Illinois and candidate markets in the Northeast and Atlantic regions

3 = A coal liquefaction plant in the West and candidate markets in the Northeast and Atlantic regions

$4=A$ coal liquefaction plant in the West and candidate markets in California 
1. IN THE EARLY STAGES OF COMMERCIALIZATION, DIRECT COAL LIQUEFACTION PLANTS WILL LIKELY BE SITED IN APPALACHIA AND ILLINOIS AND THE BOILER FUELS WILL BE MARKETED IN THE NORTHEAST AND MID-ATLANTIC AREAS; ADDITIONAL MARKET DEVELOPMENT COULD TAKE PIACE IN THE WEST AS ADDITIONAL LIQUEFACTION PLANTS ARE SITED

Booz, Allen identified four transportation networks to assess possible marketing barriers associated with the movement of coal liquefaction boiler fuels from likely plant sites to consuming areas. The two favorable transportation modes for coal-derived liquid boiler fuels are unit train rail cars and pipelines. Additional research should be conducted to determine whether coal liquids boiler fuels could be transported long distance by pipeline. Costs were determined for rail, pipeline, barge, and truck shipments to compare the different transportation modes. The following four plant-to-market systems were identified:

A coal liquefaction plant in Catlettsburg, Kentucky and candidate markets in New York, Boston, and Baltimore. The H-Coal consortium currently has a plant under construction adjacent to the Ashland refinery in Catlettsburg, Kentucky. A follow-on plant is planned for the future and may be located either in the catlettsburg area or in western Kentucky. Catlettsburg, Kentucky was selected as a point of reference for purposes of identifying transportation costs.

oil-fired utilities exist in the three cities mentioned, and the utilities have indicated a willingness to buy coal 1 iquefaction boiler fuels in the future.

or,

A coal liquefaction plant in Morgantown, West Virginia and candidate markets in New York, Boston, and Baltimore. A demonstration plant for SRC-II is planned for Morgantown and, therefore, Booz, Allen used this site for evaluation. The candidate markets are similar to the first two situations described.

A coal liquefaction plant in Southern Illinois, adjacent to Illinois No. 6 coal fields and candidata markets in New York, Boston, and Baltimore. Exxon indicated in discussions with Booz, Allen that it may locate an EDS coal liquefaction plant in this area. Therefore, an Illinois plant site was considered a likely possibility. 
- A coal liquefaction plant in Wyoming and a candidate market in California or in the Northeast. This particular scenario was raised during interviews with some industrial sector representatives and is considered to be a likely possibility. The Exxon Donor Solvent Process has used Wyoming coals in tests, and the demand forecasts show a potential candidate market for coal liquefaction boiler fuels on the West coast. Because of the potential for utilizing Wyoming coals in direct coal liquefaction processes, a Wyoming-to-San Francisco transportation scenario was selected. A Wyoming-toEast Coast system may eventually evolve also, based on comments from one of the process technology companies.

There are infrastructure barriers in all coal liquefaction to consumption configurations except for rail transportation in the Northeast and Atlantic regions.

(1) Rail Transporation Is Available in All Systems

Rail transporation exists between the selected plant sites and markets; however, unit train transport in the west may be a barrier. Rail links exist in either direction from Wyoming although rail traffic in an eastward direction may be cost prohibitive.

\section{Pipelines Are Not Available Currently in the} Candidate Systems

There are no pipelines currently available to transport coal liquid boiler fuels from a Wyoming location to the west coast. Furthermore, there are no existing pipelines capable of transporting coal liquids from either Illinois or Appalachia to the East coast. This may pose a marketing barrier in the event alternative modes of transport are not available due to physical constraints or due to economic considerations.

\section{(3) Truck Transportation Is Not a Likely Possibility}

Truck transport may be available in each case; however, each 50,000 barrel/day liquefaction plant would require approximately 750 tank trucks. Tank trucks will likely be eliminated as a candidate mode because costs are expected to be prohibitive due to the distance between plants and markets. 

the East Coast

Barge movement could take place between an East Coast port and a New York or New England market. The coal liquids could be shipped via rail from the liquefaction plants to Baltimore and barged to the consumption point.

2. PIPELINE AND BARGE TRANSPORATION ARE THE MOST ECONOMICAL MODES OF MOVING LARGE QUANTITIES OF PETROLEUM PRODUCTS; SUCH COSTS MAY BE REPRESENTATIVE OF MOVING COAL LIQUIDS

There are no data currently available to specifically assess the cost of transporting coal liquids. Transportation costs can be estimated, however, by assessing the costs of transporting petroleum products. Fipeline costs were determined for existing pipelines, and calculations are made to cost out new pipelines where pipelines do not currently exist.

(1) Exhibit 7-2 Shows the Range of Petroleum Transportation Costs By Various Modes

The exhibit shows that tanker transport is the least expensive mode, followed in increasing order of cost by :

$\begin{array}{ll}\text { - } & \text { Pipeline } \\ \text { - } & \text { Barge } \\ \text { - } & \text { Truil } \\ & \text { Truck }\end{array}$

The data were derived from National Energy Transportation, Volume I: Current Systems and Movements, issued by the Senate Committeo on Encrgy and Natural Resources in May 1977. The data were inflated to 1979 dollars by applying applicable Consumer Price Indices.

There is a range of costs for each mode indicative of the type being shipped, $i . e .$, crude and heavy residual oils would fall at the lower end of each spectrum, gasolines at the upper end. Coal liquids boiler fuels would most likely be priced in the lower end of each range, owing to its similarity to a heavy fuel oil. 
EXHIBIT 7-2

Representative Range of Petroleum Transportation

Costs by Various Modes

\section{TAir KER \\ PI PELINE}

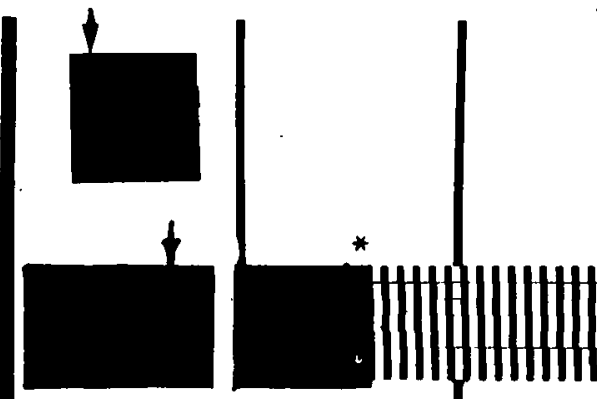

BARGE

RA I L

TRUCK

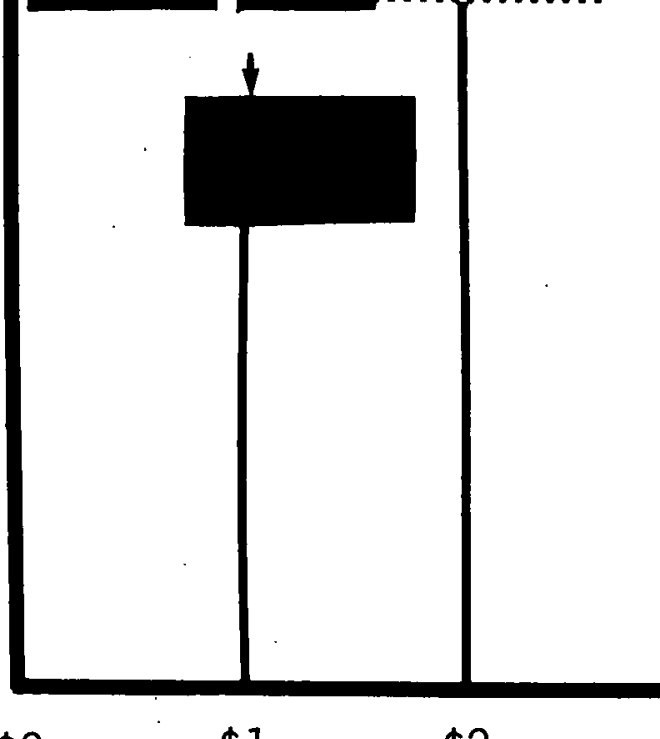

$\$ 0$

$\$ 1$

$\$ 2$

$\$ 3$

$\$ 4$

$\$ 5$

$\$ 6$

$\$ 8$

$\$ / 1,000$ PARREL MILES

* Possible cost of a new pipeline

SOURCES: Association of 0 il Pipelines,

Association of American Railroads,

American Trucking Association,

National Energy Transportation,

Volume I - Current Systems and Movements-

$t=$ Cost for a residual-type material which may be representative of May. 1977. 
The average costs of pipeline transporation compare very favorably with barge, rail, and truck. Pipelines are economically more advantageous to rail and truck transporation over similar routes. Since pipelines do not currently exist in areas where coal liquids marketing is expected to take place, a new pipeline was costed to determine likely tariffs.

$$
\frac{\text { A New } 50,000 \text { Barrel/Day Pipeline Would Require }}{\text { An Approximate } \$ 3.00 / \text { Barrel Tariff }}
$$

The Booz, Allen project team computed the cost of a new 50,000 barrel/day pipeline to join potential liquefaction plants in Appalachia and candidate markets in the East Coast. This was done to compare the cost of a new pipeline with existing transportation modes. The tariff on a new 50,000 barrel/day line between Morgantown, West Virginia, for instance, and New York comcomputed to be approximately $\$ 3.00 /$ barrel and was based on the following assumptions:

$\begin{array}{ll}\begin{array}{l}\text { Capital Cost } \\ \text { (Source: Oil and Gas Journal) }\end{array} & =\$ 150,000,000^{*} \\ & =20 \text { years } \\ \text { Pipeline Life. } & =11 \% \\ \text { Cost of Capital (Weighted Avg.) } & \\ \text { Income Tax Rate (Federal, State) } & =50 \% \\ & =1 \% \\ \text { Property Tax Rate } & =.2 \% \\ \text { Insurance Rate } & \\ \begin{array}{l}\text { Depreciation - Assumed Sum-of- } \\ \text { Year Digits (Accelerated) }\end{array} & \\ \begin{array}{c}\text { Annualized Per Barrel Cost of } \\ \text { Investment }\end{array} & =\$ 2.00 / \text { barrel } \\ \text { Operating Costs } & =\$ 1.00 / \text { barrel } \\ \text { Cost } & =\$ 3.00 / \text { barrel }\end{array}$

\footnotetext{
* Based on construction costs of new pipelines planned in virginia and west Virginia. This figure is a representative number and is believed to approximate what the cost would be. Definitive costing depends on actual rights of way selected, elc.

** Assumption: 50\%' debt, $50 \%$ equity.
} 
Exhibit 7-3 Reflects the Likely Cost of Transporting a Coal Liquid-Type Material under Each of the Foregoing Transporation Networks

Costs were determined for moving a residual oil of similar API gravity by obtaining freight quotations from various freight companies. Railroad industry representatives believe that coal liquids will probably cost the same to ship as heavy residual fuel oil, which is currently about $2.6 \mathrm{c} / \mathrm{ton}$ mile, or about $.4 \mathrm{c} / \mathrm{barrel}$ mile. Pipeline companies generally were not familiar with coal liquids specification and could not comment airectly on costs. However, based upon their limited knowledge of coal liquids boiler fuel material, pipeline representatives indicated that the tariff for a heavy crude oil could be used for preliminary costing purposes, which is approximately.lc/barrel mile. Key observations from the exhibit are:

- In no case is the least expensive transportation mode-pipeline-currently available to transport coal liquefaction boiler fuels to likely candidate markets.

- Truck transportation is generally 30 percent higher than rail transportation in all cases except the Wyoming to San Francisco route. The high rail transporation for this route is due to the mountainous area that causes slow freight movement and attendant higher per unit costs.

- Barges can be utilized to ship coal liquids from Baltimore to New York and Boston; how: ever, a rail/barge combination is mure expensive than rail shipment. nnly.

- Rail and truck shipments could pose key market entry barriers because of cost considerations. 
EXH IBIT 7-3

Possible Transportation Costs of Coal Liquids Shipments-

Based on Costs of Residual Oil Shipments

( \$/Barrel)

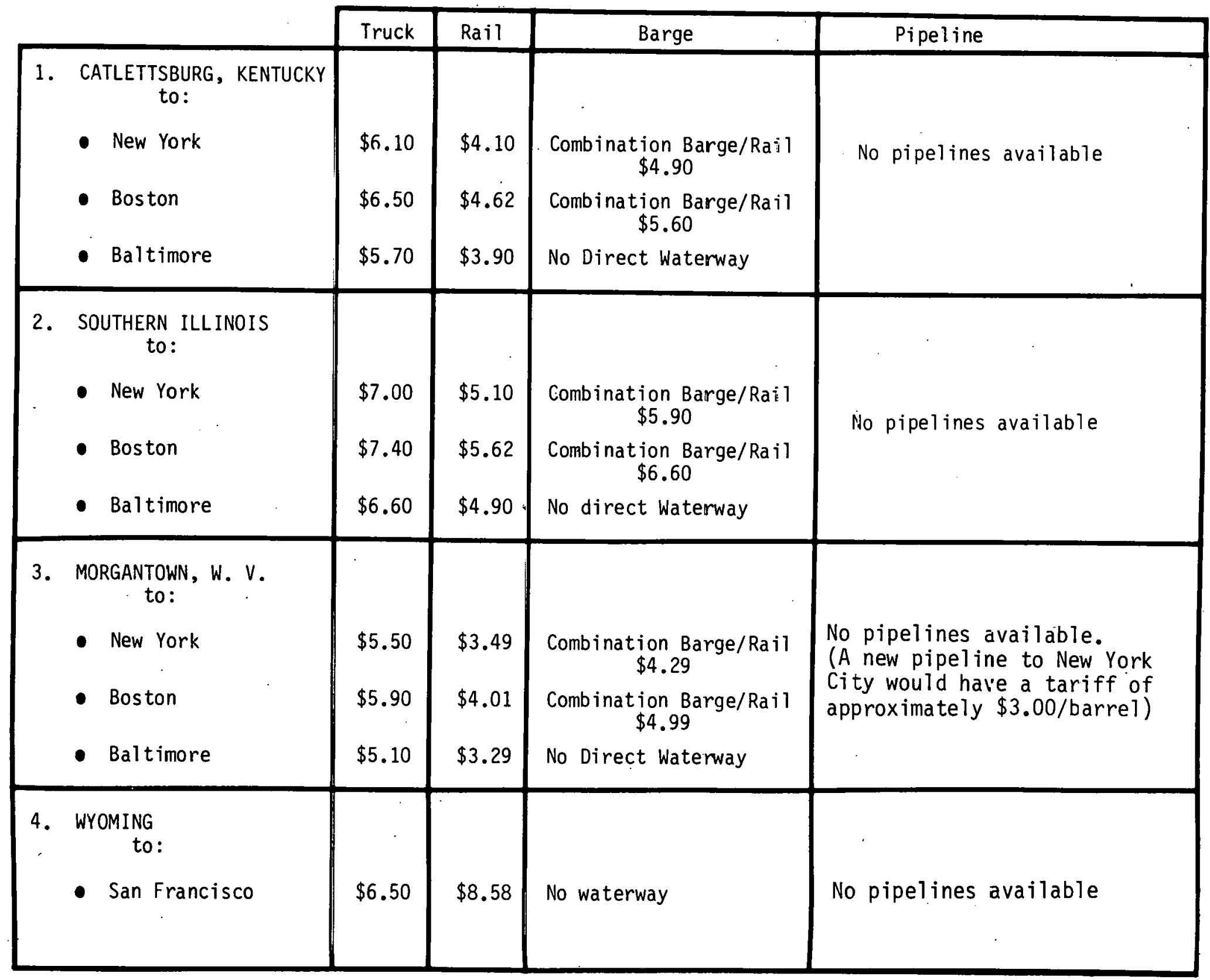


(4) Additional Research Should Be Conducted on the Technical Question of Pipelining Coal Liquids Boiler Fuels Because This would Be the Most Economical Transportation Mode in Some Cases

A large pipeline company is currently conducting research in this area; however, it would not discuss its work with Booz, Allen as the company advised it was a proprietary job for the Department of Energy:

- The results of the ongoing research are expected in the next three to six months, and a more informed judgment about pipelining can be made at that time.

- While pipelines are currently the most competitive mode, the construction of a new pipeline to carry coal liquids will increase per-barrel costs. Preliminary analyses show new pipelines may not be cost competitive with other transportation modes in some markets.

Additional research needs to be conducted in the following areas to ascertain the likelihood of moving coal liquids bỹ rall should lie pipelines not bc available by 1990 :

- Availability of rail cars in the 1985-1990 timeframe

- Adequacy of the railroad beds in the Northeast Corridor and in the Rocky Mountain area.

3. ENVIRONMENTAL SAFEGUARDS WILL BE REQUIRED TO ALLEVIATE THE POTENTIAL RISKS ASSOCIATED WITH ACCIDENTIAL SPILLS OF COAL LIQUEFACTION PRODUCTS AND ADDITIONAL RESEARCH IS NEEDED TO THOROUGHLY EVALUATE THE INCREMENTAL COSTS

Environmental safeguards for transporting coal liquefaction fuels have not yet been fully designed for commercial applications; and therefore, total costs are currently unknown. Countermeasures may be designed to reduce accident probability or consequence, and such countermeasures may influence equipment required, transportation and handling procedures needed, and the accident environment.

Costs of countermeasures to contain the environmental hazards of coal liquefaction products may be estimated from 
the costs of accidents involving petroleum products. The following sections describe the current means of moving petroleum, focusing on the physical factors of movement. The four basic modes of petroleum transportation are addressedrailroads, pipelines, water carriers, and trucks.

(1) Environmental Costs Associated With Rail Shipments Can Only Be Estimated Based on Accident Experiences With Hazardous Materials

Crude oil and petroleum products carried on railroads in 1978 amountod to 575,000 barlels per day, or approximately 2.8 percent of the total volume of petroleum moved into United States commerce (Association of American Railroads). Expressed in ton miles, the railroad market share was approximately 1.8 percent. The railroads' share of the petroleum transportation market has remained at about the same level for the last ten years. For some products, such as liquefied petroleum gases, rail transportation is one of the most practical modes because of the volatile nature and low volumes of commodity shipment.

Countermeasures directed at rail accidents have certain common requirements: .

- A measure of total cost (risk) associated with the environmental problem is required to provide a reference for estimating benefits.

- Assuming a countermeasure is in place, a basis must be established for estimating the reduced accident rate, consequences, and rigk.

- The cost of implementing the countermeasure must be determined.

- Costs must be compared with the estimated benefits or effectiveness.

Approximately 9,000 to 10,000 railroad accidents are reported each year. of these, approximately 700 include trains carrying hazardous materials; and in approximately 100 of these accidents, hazardous materials are released. Of these 100, the number of accidents investigaged by the National Transportation Safety Boara as a result of their serious nature has averaged about two per year. 
The total annual cost of railroad accidents averages about $\$ 200$ million per year (in 1978). The accidents in which hazardous materials are released represent about one percent of the total number of accidents and account for about 5 percent of the total damage cost. The cost of derailments involving release of hazardous materials averaged $\$ 107,000$ per year versus an average cost of $\$ 11,500$ for all derailments (Association of American Railroads).

A study done in 1978 for the Association of American Railroads concluded that trains with one or more hazardous materials cars have an accident rate substantially less than trains with no hazardous materials cars. This is thought to be due in part to travel on higher density routes with better track, use of better equipment, and better discipline in handling of hazardous materials trains.

Environmental Safeguard Costs Associated With Pipeline Transportation of Coal Liquids Could Be Assessed Based on Petroleum shipments

There are approximately 77,000 miles of crude oil trunk pipelines and 76,000 miles of refined products trunk pipelines in the United states according to the Energy Information Administration at DOE. Certain petroleum products have properties or uses in common with others and cause less serious contamination when carried in conjunction with each other. Batch shipments in these cases alleviate compatibility problems.

Gulf Mineral and Resources Company has had extensive analyses performed on the SRC-II coal liquids to determine whether or not this material could be transported by pipeline. Test results indicate that there would be no logistical barriers to pumpting as much as 100,000 barrels per day of SRC-II material through a 16'inch diameter pipeline. Furthermore, the tests indicate that SRC-II could be pumped throughout the year in the Northeast without heating or insulation.

A data base does not exist for determining the costs of transporting a coal liquefaction boiler fuel type material via pipeline; and therefore, it is not currently possible to determine the incremental costs associated with transporting coal liquefaction boiler 
fuels by this mode. However, costs can be estimated by assessing the transportation of petroleum. Since heavy fuel oil does not move by pipeline, a reference would be a middle distillate product which can be shipped for about .06 $/$ /barrel mile. The cost of transporting crude oil can also be used as a reference. crude oil shipping costs are approximately .1\%/barrel mile. The enviornmental safeguard costs associated with long-distance pipelining of coal liquefaction boiler fuels should be no greater than that for other types of oil shipments because pipeline are closed systems that considerably reduce the risk of human exposure to the materials being transported. There were no incremental environmental control costs associated with pipeline shipment of coal liquid boiler fuels identified during the course of this study. An area that warrants further examination is the cleanup costs associated with possible pipeline ruptures.

Coal I.iquid Boiler Fuels May Move by Water in Some Cases and the Environmental Costs Associated With This Mode Could Be Estimated by Reviewing Petroleum Spilis

Most water transportation of petroleum involves the large volume of residual fuel oil imported from Caribbean and European refineries to utilities and industrial users along the East Coast where residual oil is used for a boilex fuel. During the week ended July 27, 1979, 1.1 million barrels/day of residual oil was imported to the East coast. In domestic coastwise traffic, residual fucl oil shipments ate approximately 500,000 barrels/day. The East coast could have the largest amount of coal liquids movement by waterborne means as it is this area that could be an early candidate market.

Oil spill liability is an area in which considerable experience has been gained. Although minor spills and fueling accidents account for some oil lost to the environment, these relatively minor accidents are difficult to cost. The major oil spills and the substantial cleanup costs associated with them are of interest for this study since they may offer some guidance to the costs associated with coal liquefaction accidents involving water-borne vessels. Some major oil spills include:

- Torrey Canyon, English Channe1, 1967:

$$
\begin{aligned}
& \text { - 650,000 barrels } \\
& \text { - Cleanup cost } \$ 5 \text { million ( } \$ 7.70 / \text { barrel) }
\end{aligned}
$$


- Oil well blowout, Santa Barbara, California, i969:

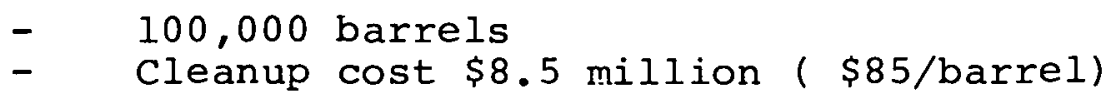

- Barge spi11, Chesapeake Bay, February 1976 :

$$
\begin{aligned}
& \text { - } 250,000 \text { gallons } \\
& \text { - Cleanup cost } \$ 300,000 \text { (\$35/barrel) }
\end{aligned}
$$

- Argo Merchant, Massachusetts, December 1976 :

$$
\begin{aligned}
& \text { - } \quad 180,000 \text { barrels } \\
& \text { - Cleanup cost } \$ 5.2 \text { million ( } \$ 29 / \text { barrel) }
\end{aligned}
$$

- Amoco Cadiz, France, 1978:

$$
\begin{aligned}
& \text { - } \quad \text { l,540,000 barrels } \\
& \text { - Cleanup cost } \$ 30 \mathrm{million}(\$ 19.50 / \text { barrel). }
\end{aligned}
$$

The total amount of spillage for these five accidents alone was approximately 2.5 million barrels at a total cost of $\$ 49$ million, or approximately $\$ 19.60$ per barrel on an average basis.

Coal liquefaction products would most likely be shipped in 10,000 - 20,000 barrel barges, owing to the amount of coal liquids being produced in the early stages of commercialization and the likely markets along the East Coast.

The Chesapeake Bay barge spill cited would probably be the most similar type of accident to a coal liquefaction spill, in the event a spill actually took place. At $\$ 35$ per barrel, a 10,000 barrel barge accident could conceivably cost $\$ 350,000$ to clean up. This area warrants additional research to determine the extent of dissimilarities between oil spills and coal liquefaction spills.

There are Federal programs designed to compensate oil pollution victims. These programs, summarized in Exhibit 7-4, could potentially be expanded to include accidents involving coa] liquids and, therefore, are described here briefly. 
EXHIBIT 7-4

Existing Federal Oil spill Liability and Compensaticn Programs

\begin{tabular}{|c|c|c|c|c|}
\hline . & $\begin{array}{l}\text { Federal water } \\
\text { Pollution } \\
\text { Control Act } \\
\text { (PWPCA) }\end{array}$ & $\begin{array}{l}\text { Trans-Alaskan } \\
\text { Pipeline } \\
\text { Authorization } \\
\text { Act (TAPA) }\end{array}$ & $\begin{array}{l}\text { Outer } \\
\text { Contirental } \\
\text { Shelf Lands } \\
\text { Act (CICSLA) }\end{array}$ & $\begin{array}{l}\text { Deepwater } \\
\text { Port Act } \\
\text { (DPA) }\end{array}$ \\
\hline ADMINISTRATION & $\begin{array}{l}\text { Department of } \\
\text { Transportation, } \\
\text { Coast Guard }\end{array}$ & $\begin{array}{l}\text { Department } \\
\text { of the } \\
\text { Interior }\end{array}$ & $\begin{array}{c}\text { Departnent } \\
\text { of } \\
\text { Transportation }\end{array}$ & $\begin{array}{l}\text { Department } \\
\text { of } \\
\text { Transportation }\end{array}$ \\
\hline COSTS, DAMAGES & $\begin{array}{l}\text { Containment, dispersal, } \\
\text { and removal; restoration, } \\
\text { replacement of natural } \\
\text { resources }\end{array}$ & $\begin{array}{l}\text { Cleanup costs, damages } \\
\text { to natural resources } \\
\text { relied upon for sub- } \\
\text { sistence }\end{array}$ & $\begin{array}{l}\text { Removal costs; } \\
\text { damages to real or } \\
\text { personal property, } \\
\text { loss of natural re- } \\
\text { sources, economic } \\
\text { loss }\end{array}$ & $\begin{array}{l}\text { Cleanup, removal, } \\
\text { mitigation; real or } \\
\text { personal property, } \\
\text { natural resources }\end{array}$ \\
\hline \multicolumn{5}{|l|}{ FUND } \\
\hline Size & $\$ 35,000,000$ & $\$ 100,003,000$ & $\$ 200,000,000$ & $\$ 100,000,000$ \\
\hline & $\begin{array}{l}\text { Appropriated, fines, } \\
\text { penalties }\end{array}$ & 5 cents per barrel & 3 cents per barre 1 & 2 cents per barrel \\
\hline JURISDICTION & $\begin{array}{l}\text { Navigable waters, } \\
\text { contiguous zone, } \\
\text { OCS activities, } \\
\text { 200-mile fishery } \\
\text { conservation zone }\end{array}$ & $\begin{array}{l}\text { Our vessels engaged } \\
\text { in transporting TAPA } \\
\text { oil between terminal } \\
\text { facilities of the } \\
\text { pipeline and ports } \\
\text { under the jurisdiction } \\
\text { of the U.S. }\end{array}$ & $\begin{array}{l}\text { In or on OCS waters, } \\
\text { waters of adjacent } \\
\text { coastal states, } \\
\text { waters of contiguous } \\
\text { zone }\end{array}$ & $\begin{array}{l}\text { From a vessel within } \\
\text { the marine safety } \\
\text { zone, from a vessel } \\
\text { which has received } \\
\text { oil from another } \\
\text { vessel at a deep- } \\
\text { water port, or from } \\
\text { a deepwater port }\end{array}$ \\
\hline
\end{tabular}


1. The Federal Water Pollution Control Act (FWPCA)

This act establishes oil pollution liability for vessels and facilities and provides a cleanup fund. The fund is designed to facilite cleanup efforts by guaranteeing cleanup money immediately following an accident and allowing settlement of liability for such costs between the fund and the spiller.

2. The Trans-Alaska Pipeline Authorization Act (TAPAA)

TAPAA addresses environmental cleanup liabilities associated with handling Alaskan North Slope crude oil. The 1.iability and compensation provisions apply to Alaska North slope crude oil transported by water-borne means. The main reason for the special liability provisions was the route Alaskan crude oil would take to the United States. There were concerns that ecologically fragile coastal areas might be subject to oil spills, endangering fishing and other marine resource dependent industries.

3. The Outer Continental Shelf Lands Act Amendments

These amendments establish liability and compensation procedures covering offshore oil and gás. development activities: The provisions cover any spill involving Outer Continental Shelf oil, including spilis from offshore facilities and vessels.

4. The Deepwater Port Act

This act would establish a fund for oil spill cleanup of accidents involving vessels loading or discharging at a deepwater port. The fund is not yet established because no deepwater ports are yet in operation.

(4) Truck Transport Does Not Appear To Be a Satisfactory lode for Transporting Coal Liquids Over Long Distances

Truck transportation accounts for approximately 3 percent of the crude oil and petroleum products moved. 
This is indicative of the fact that truck transportation is more practical for short-distance delivery to end users than for long-distance bulk transport. Although trucks have much more freedom of movement than any other mode of transportation and can supply petroleum to any type of customer, truck transportation is not competitive for long-distance runs due to lower unit volumes of each shipment.

An area where trucks could be used to move coal liquefaction boiler fuels is in distribution from bulk terminals to end-use utilities or industries. spills from trucks carrying coal liquids would be similar to heavy oil spills. The attendant cleanup costs would be similar and are not expected to be prohibitive.

4. SAFETY STANDARDS THAT WILL BE IMPLEMENTED ARE NOT EXPECTED TO BE COST PROHIBITIVE

The environmental assessment presented in Chapter 5 indicates that while the potential hazards to workers exposed to coal liquefaction products will be greater than those of residual fuel oil, the hazards can be controlled with adequate safeguarde. The main elements of worker safety and health. controls would include strict hygiene procedures and minimization of exposure during cleanup operations. Associated costs would depend on the size of the end-use market and number of personnel employed at each end-use location. Costs were not determined for safety procedures because existing data are very diffused, various environmental hazards may develop, and costs would depend on the magnitude of the coal liquids shipment. Additionally, the total costs of the 30-year monitoring program initiated by OSHA are currently unknown.

5. HANDLING REQUIREMENTS OF COAL LIQUEFACTION BOILER FUELS CAN BE ASSESSED FROM THE SRC-II TEST BURN EXPERIENCE

The coal liquefaction fuel oil utilized for the Consolidated Edison test burn was produced at the SRC-II pilot plant at Ft. Lewis, Washington and was transported to the 74 th street power station via a combination of rail and barge transport.

During the production phase at the Ft. Lewis pilot plant, the SRC-II fuel oil was stored under a nitrogen atmosphere as a safeguard since there were uncertainties associated with the long-term storage stability. Although there has 
been very limited stability testing performed to date, there is no indication that insoluables formation is significantly different from that experienced with conventional petroleum fuel oils. No problems were encountered in transporting the SRC-II fuel oil from the pilot plant to the power station in New York.

The SRC-II fuel oil was transported from Ft. Lewis, Washington to Bayonne, New Jersey in rail cars which were rated for 100 psig, had pressure safety relief valves set for 75 psig, and were injected with a nitrogen atmosphere following loading. No problems were experienced during the shipment. Discussions with Gulf Mineral Resources Company representatives indicated no major handling requirements were necessary other than to ensure that human contact was minimized.

The SRC-II material. was transferred from the rall tank cars to a barge at Bayonne, New Jersey. An inspection of the rail cars was made prior to unloading to check for any leaks or danage. No problems in this areas were encountered. Next, the rail tank cars, barge, and the unloading line were electrically grounded. A supply of nitrogen was installed for unloading the rail tank cars. Nitrogen and hose fittings were installed to supply nitrogen to the tank cars to provide an inert atmosphere.

After all loading line fittings were tested, all valves were opened and the transfer from the first rail car to the barge began. After this rail car had heen emptied, it was repressurized to clear out any remaining SRC-II material in the lines. The car was repressurized, the valves closed, and the unloading procedure was repeated for the remaining cars.

The trarsfer of Llie SRC-II material from the barge to fuel storage facilities at the 74 th street station was successful; and tinere vere no leaks, no degradation in pumping capacity, or delivery pressure problems reported. Con Ed advised that fuel oil piping modifications required at the 74 th street power station were relatively minor.

The SRC-II handling system was isolated from the No. 6 fuel oil system by using isolation values that were already installed. The system's integrity was tested prior to the SRC-II test burn to ensure leak tightness, and separate booster pumps and fuel oil meters were installed in the SRC-II system ais were fuel oil meters calibrated for ,SRC-II fuel oil service. 
Representatives of the industrial marketplace indicated that additional tests such as the one at Con Ed need to be held not only to establish combustion suitability, but also to establish whether additional transportation and handling requirements need to be developed for coal liquefaction prodcuts. Attempts by Booz, Allen to quantify the costs associated with the Con Ed test burn were not successful as companies indicated the data were proprietary and not available for release.

Since only a relatively small amount of coal liquids were transported to the Consolidated Edison Power Station $(4,500$ barrels), the lack of attendant problems may not be indicative of transporting 50,000 - 100,000 barrels/day, which is ultimately envisioned. A whole scale increase in coal liquids transportation has marketing implications with respect to:

\footnotetext{
- Availability of rail cars

- Adequacy and availability of railroad beds to transport coal liquids from plant sites to candidate markets

- Adequacy or availability of pipelines to carry coal liquids from plant sites to candidate markets

- Adequacy of storage facilities at end-use locations.

These factors warrant additional evaluation to completely ascertain transportation and handling requirements for the
} 1985-1990 timeframe. 
CHAPTER 8

THE GOVERNMENT'S ROLE IN ACCELERATING MARKET DEVELOPMENT FOR COAL LIQUEFACTION PRODUCT BOILER FUELS 
CHAPTER 8

THE GOVERNMENT:S ROLE IN ACCELERATING MARKET DEVELOPMENT FOR COAL LIQUEFACTION PRODUCT BOILER FUELS

The preceding chapters addressed the current status of process technology, forecasted the potential boiler fuel market, evaluated the potential environmental hazards and institutional issues, and assessed transportation and handling requirements. This chapter takes account of these findings and considers how government could accelerate market development for coal liquefaction products used as boiler fuels.

This chapter is presented in three parts:

- Interrelationship of industrial and government sectors

- Identification of problems to be overcome

- Recommendations from the industrial marketplace on Federal initiatives.

1. THE PACE OF COAL LIQUIDS MARKET DEVELOPMENT WILL BE DEPENDENT ON THE INTERRELATIONSHIP OF THE INDUSTRIAL AND GOVERNMENT SECTORS

Exhibit 8-1 shows the channels of communications between each of the marketplace sectors. The entire marketing system will be developed by "demand pull" from the end-use level. This means that the end-use economic advantage of using a coal-derived liquid as a boiler fuel will "pull" the process technology through to commercialization readiness and subsequently toward a deliverable product in the marketplace. Each of the marketplace sectors are identified as follows:

The process technology companies will develop the coal-derived liquid for potential boiler fuel use consistent with market demands for that type of product.

- The DOE and EPA are responsible for administering a variety of research and development programs in the process technology area and in the environmental area, respectively. 
EXHIBIT 8-1

Components of the Industrial Market System Involved in the Commercialization of Direct Coal Liquefaction Boiler Fuels

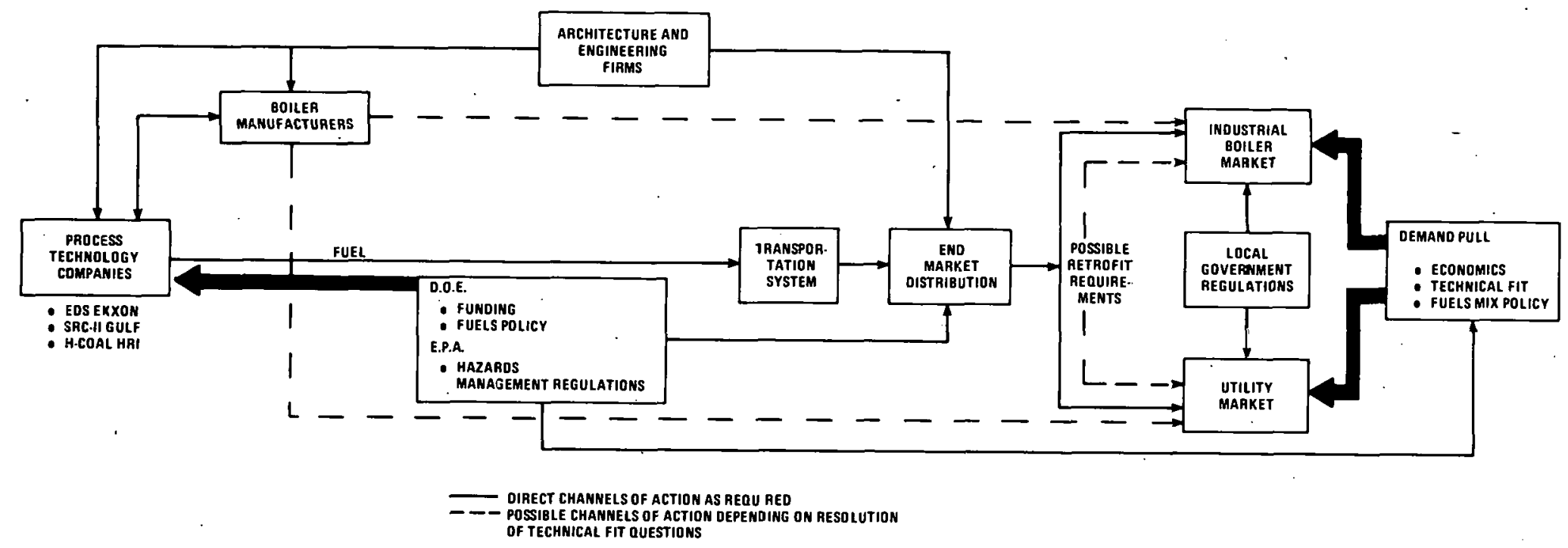


- DOE administers the research funding programs and is responsible for administering the implementing regulations of the Powerplant and Industrial Fuel Use Act. The fuels mix policy established by DOE will influence end-use market demand.

- Boiler manufacturers will interact with the process technology companies and the boiler owners to design boilers that can utilize the types of fuel produced and that will meet the market requirements at the end-use.

- Architecture and engineering firms interact with the process development companies to design and construct the liquefaction plants and will be included in end-market distribution through the design and construction of terminalling and storage facilities.

- The utility and industrial boiler owners will be the end-use markets for the boiler fuels and their purchase decisons will be influenced by local government regulations as well as by Federal Government policies.

- Local governments will issue regulations covering the treatment of boiler fuel costs in the utility rate structure. Inother area of local government concern will be the use of potentially hazardous fuels in populated areas. There may be some societal opposition in this area.

2. UTILITY AND INDUSTRIAL BOILER FUEL MARKET REPRESENTATIVES ARE FAMILIAR WITH COAL LIQUEFACTION TECHNOLOGY AND ITS APPLICATION TO BOILER FUEL PRODUCTION AND CONCLUDED THAT COAL-DERIVED LIQUIDS ARE NOT CURRENTLY ECONOMICALLY ATTRACTTVE

Industrial sector representatives believe market development barriers vill be economic considerations rather than environmental hazards. The major conclusions drawn from a series of interviews held with a cross section of industrial representatives are as follows:

Most of the large boiler manufacturers who would be in a position to enhance marketability of coal liquids are generally knowledgeable about coal liquefaction products; however, they do not see these fuels as being economically attractive today. 
- Oil-fired utilities are knowledgeable about coal liquids fuels. They do not believe them to be economically attractive but are willing to pay a premium to obtain a secure and stable source of fuel.

- Industrial boiler owners are knowledgeable about coal liquefaction products and do not believe them to be economically attractive. However, they want to see additional test burns conducted to establish technical suitability.

- Industry perceives coal liquefaction as being a potential solution to the energy shortfall but does not believe markets will develop until the economic climate improves for process technology commercialization.

- The industrial sector would like to see additional, large-scale tests conducted and requests more widespread dissemination of test results.

- Although most marketplace representatives are familiar with the SRC-II boiler fuel, little is known about EDS and $\mathrm{H}-\mathrm{Coal}$ boiler fuels.

3. THE INDUSTRIAL SECTOR RECOMMENDS THE CREATION OF AN ATTRACTIVE ECONOIIIC ENVIRONMENT, CONTINUOUS RESEARCH AND DEVELOPMENT EFFORTS, AND CLARIFICATION OF REGULATORY ISSUES AS THE MEANS FOR DEVELOPING A COAL LIQUIDS BOILER FUEL MARKET

Market development for coal liquefaction boiler fuels will be constrained by end-use economic considerations which could be overcome by legislative action. The unattractive cost of coal liquefaction products is a result of the large amount of capital required for plant development and construction. Prices for coal liquids could be reduced if the economics of liquefaction plant development could be improved.

(1) The Most Effective Way To Increase the Economic Attractiveness and Increase the Return-on-Investment Capital Is To Provide for Larger Investment Tax Credits and Accelerated Depreciation

Coal liquefaction processes under development provide products with prices much higher than prices for petroleum fuels and, therefore, are not economically 
attractive to investors. Because of increased uncertainty and unfavorable process economics, investors are hesitant. to commit the large funds required for the commercialization of coal liquefaction technology.

There are various incentives that could be employed to encourage the private sector to proceed with commercial development:

- Providing price subsidies to allowing coal liquefaction products to be priced competitively with marginal supply

- Providing for higher investment tax creditswhich would require a legislative initiative

- Providing for more rapid accelerated depreciation-which may require a legislative initiative in the event the Internal Revenue Code needs legislative approval for modification.

Loan guarantees have attracted widespread attention as incentives for commercial development, but the investment community generally does not support loan guarantees since a loan guarantee can neither raise the return on investment on a project nor make an uneconomic project economically viable. The conditions for private sector investment appear to be a combination of lower production costs and higher product prices.

(2) Ndditional Tests Should Be Conducted on All Three Direct Liquefaction Fuels To Confirm Combustion Suitability

All marketplace representatives, including utility and industrial market personnel, expressed strong interest in seeing additional tcst burns conducted. Industry is very interested in conducting large-scale test burns on H-Coal and EDS fuels. Most companies are familiar with the SRC-II experience but are not convinced of $\mathrm{H}$-Coal or EDS combustion suitability.

(3) EPA Treatment of Coal Liquefaction Products Will Need To Be Clarified Before the End-Use Market Will Respond

Marketplace representatives do not believe that potential environmental hazards will be market entry barriers for coal liquids. Nonetheless, industry perceives EPA's heavy handedness as delaying market 
development. Host boiler fuel market representatives believe that commercialization readiness will be achieved only if technology development proceeds absent final conclusions on environmental questions.

Exhibit $8-2$ is a matrix of Government actions that could be.taken to enhance coal liquids market development. It is based on the study's findings in the technical, marketing, environmental, and financial areas. 


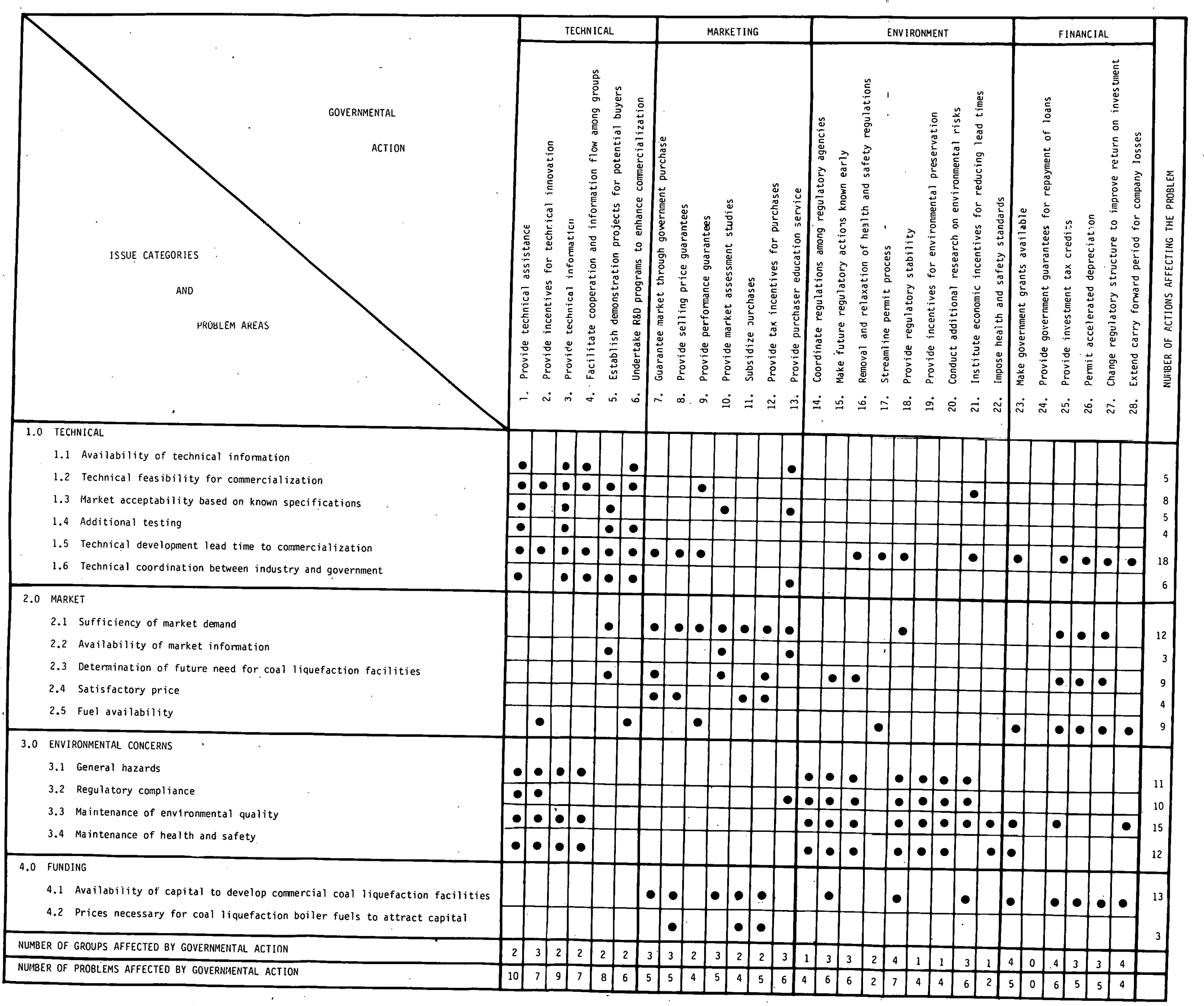


APPENDIX A

SIJPPORTING DATA TO UTILITY AND

INDUSTRIAL MARKET FORECASTS 
SUPPORTING DATA TO UTILITY AND INDUSTRIAL IIARKET FORECASTS

This appendix presents regional and national forecasts of utility and industrial fuel consumption from 1980 to 1990 ana data concerning utility capacity expansion plans, existing oil and gas steam plants, and projected new oil and gas steam plants.

The forecasts and data were based on information supplied to Booz, Allen by the Energy Information Administration of DOE. In all cases, the most recent published forecasts and data were used. The impacts of the President's recent energy proposals, Three Mile Island, and the oil price escalation imposed by OPEC are not directly incorporated into the forecasts. These forecasts, therefore, may differ from more recent statements and announcements made by the Administration and DOE. The general conclusions and discussions concerning the utility and industrial forecasts discussed in Chapter III will not be markedly affected by recent forecast revisions.

The supporting data and forecasts are presented in four parts:

Electric Utility Fuel Consumption Forecasts

Electric Utility Capacity Expansion Forecasts

Electric Utility Oil and Gas steam Plant larket Data

- Industrial Fuel Consumption Forecasts 
ELECTRIC UTILITY FUEL CONSUMPTION FORECASTS 
EXHIBIT A-1

Summary $0 \equiv$ Primary Energy Source Inputs to U.S. Electricity Generation

\begin{tabular}{|l|r|r|r|c|}
\hline \multirow{2}{*}{ Primary Fuels } & \multicolumn{3}{|c|}{ 'iuadrillijn Btu's } & Annual Growth Rates \\
\cline { 2 - 5 } & 1978 & 1985 & 1990 & $1978-1990$ \\
\hline Coal & 10.8 & 15.4 & 22.1 & 6.1 \\
Residual 0i1 & $\mathbf{3 . 7}$ & 4.0 & 2.8 & -2.3 \\
Distillate 0i1 & $\mathbf{0 . 3}$ & 0.5 & 0.4 & 2.4 \\
Natural Gas & $\mathbf{3 . 3}$ & 2.1 & 0.5 & -14.5 \\
Nuclear & 3.0 & 6.6 & 9.4 & 10.0 \\
\hline \multicolumn{1}{|c|}{ Total } & 21.1 & 28.6 & 35.1 & 4.3 \\
\hline
\end{tabular}

Sources: 1978 consumption data are preliminary estimates supplied to Booz, Allen by the Coal \& Electric Power Analysis Division, Bureau of Applied Analysis of DOE.

1985 and 1990 forecast data were obtained from supporting computer runs to the Analysis Report, Energy Supply \& Demand in the Midterm: 1985, 1990, 1995, Apri1 1979, DOE/EIA-0102/52. 
EXHIBIT A-2

Summary of Primary Energy Source

Inputs to U.S. Electricity Generation

1978-1990

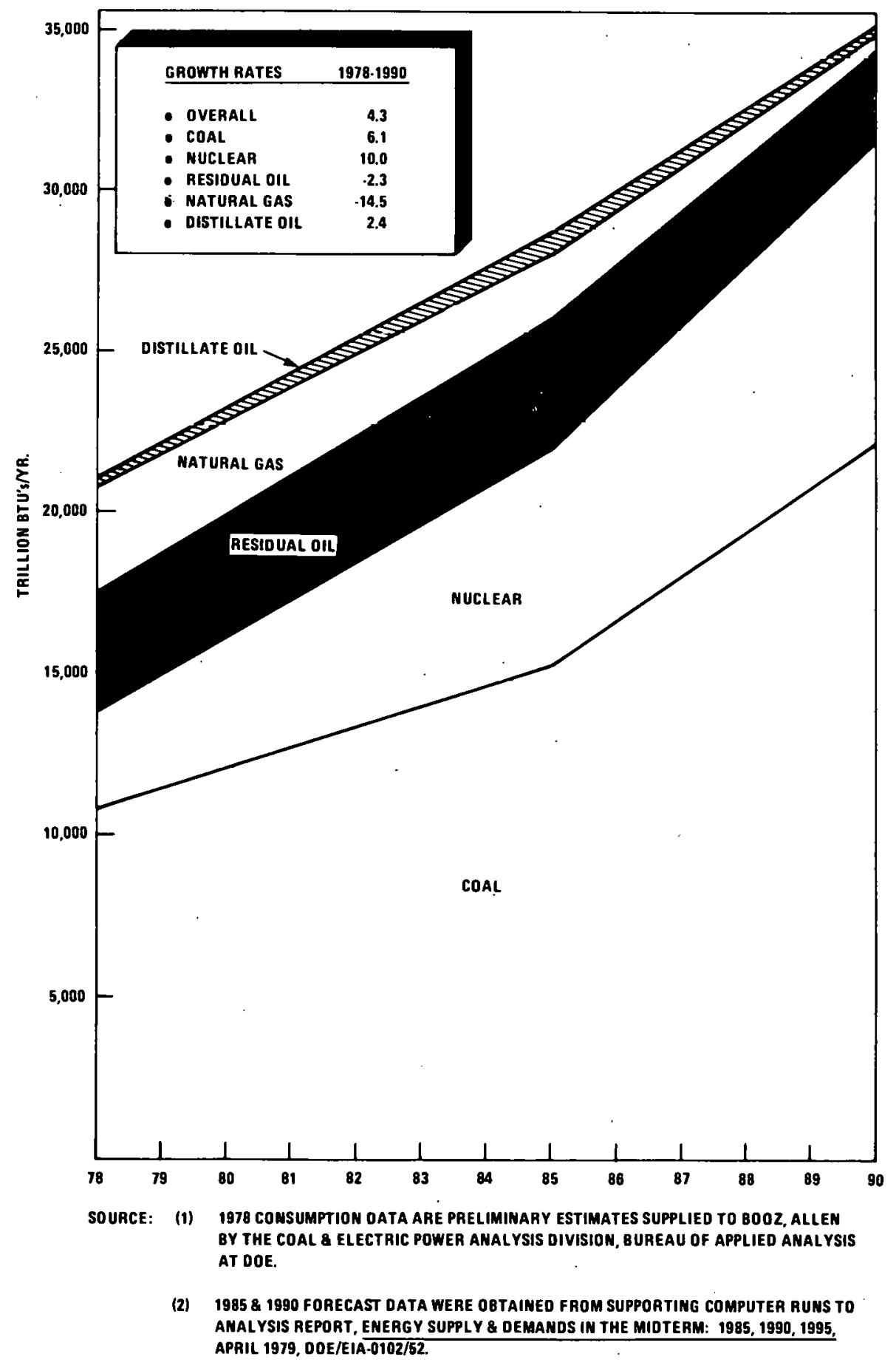


EXHIBIT A-3

Summary of Regional Data of Primary Energy Source Inputs to U.S. Electricity Generation 1978

\begin{tabular}{|c|c|c|c|c|c|c|c|c|c|c|}
\hline \multirow{2}{*}{ Primary Fue] } & \multicolumn{10}{|c|}{ Fegional Utility Consumption in Trilitions of $\mathrm{Btu} / \mathrm{Yr}$} \\
\hline & New Eng. & $\mathrm{NY} / \mathrm{NJ}$ & Mid Atr. & S. Atl. & Midwest & S. West & Central & N. Central & N. West & Total \\
\hline Coal & 18 & 191 & 1,626 & 2,580 & 3,534 & 813 & 870 & 855 & 248 & 10,836 \\
\hline Residual $0 i 1$ & 466 & 710 & 534 & 657 & 263 & 286 & 40 & 7 & 725 & 3,688 \\
\hline Distillate $0 i 1$ & 5 & 27 & 35 & 84 & 69 & 4 & 20 & 3 & 29 & 282 \\
\hline Natural Gas & 2 & 2 & 4 & 225 & 77 & 2,326 & 170 & 39 & 386 & 3,256 \\
\hline Nuclear & 308 & 329 & 509 & 795 & 790 & $5 ?$ & 98 & 6.6 & 85 & 3,040 \\
\hline Total & 799 & 1,259 & 2,708 & 4,341 & 4,733 & 3,486 & 1,198 & 910 & 1,473 & 21,102 \\
\hline
\end{tabular}

Note: Standard Federal regions are classified as follows:

1. New England: Maine, Massachusetts, New Hampshire, Connecticut, Rhode Island, Vermont

2. New York/New Jersey: New York, New Jersey

3. Mid-Atlantic: Pennsylvan-a, West Virginia, Virginia, Maryland, Delaware, District of Columbia

4. South Atlantic: Kentucky: Tennessee, North and South Carolina, Georgia, Alabama, Mississippi, Florida

5. Midwest: Ohio, Michigan, Indiana, Illinois, Wisconsin, Minnesota

6. Southwest: Louisiana, Arkansas, Dklahcma, Texas, New Mexico

7. Central: Kansas, Missouri, Iowa, Netrcska

8. North Central: Colorado, Utah, Wyoming, Montana, South and North Dakota

9. West: Arizona, Nevada, California, tawaii

10. Northwest: Idaho, Oregon, Washingtor, Alaska

Source: 1978 consumption data are preliminary Estimates supplied to Boaz, Allen by the Coal \& Electric Power Analysis Division, Bureau of Applied. Aralysis, DOE 
EXHIBIT A-4

Summary of Regional Forecasts of Primary Energy Source Inputs to U.S. Electricity Generation 1985

\begin{tabular}{|c|c|c|c|c|c|c|c|c|c|c|c|}
\hline \multirow{2}{*}{ Primary Fuel } & \multicolumn{11}{|c|}{ Regional Utility Consumption in Trillions of $\mathrm{Btu} / \mathrm{Yr}$} \\
\hline & New Eng. & NY/NY & Mid. Atl. & S. Atl. & Midwest & S. West & Central & N. Central & West & N. West & Totàl \\
\hline Coal & 158 & 450 & 2,092 & 3,888 & 1,501 & 1,900 & 1,192 & 632 & 632 & 215 & 15,442 \\
\hline Residual 0i1 & 562 & 1,067 & 118 & 685 & 296 & - & 40 & - & 1,225 & - & 3,993 \\
\hline Distillate $0 i 1$ & 95 & 69 & 31 & 35 & 63 & 28 & 19 & - & 133 & - & 473 \\
\hline Natural Gas & - & - & - & 7 & 0.5 & 2,040 & - & - & - & - & 2,047 \\
\hline Uranium Fue & 289 & 594 & 833 & 1,768 & 1,607 & 486 & 263 & 24 & 460 & 243 & 6,567 \\
\hline Total & 1,104 & 2,180 & 3,074 & 6,383 & 6,468 & 4,454 & 1,514 & 656 & 2,232 & 458 & 28,522 \\
\hline
\end{tabular}

Source: 1985 forecast data were obtained from supporting computer runs to Analysis Report, Energy Supply \& Demand in the Midterm: 1985; 1990, 1995, Apri1 1979, DOE/EIA-0102/52. 
EXHIBIT A-5

Summary of Regional Forecasts of Primary Energy Source Inputs to U.S. Electricity Generation 1990

\begin{tabular}{|c|c|c|c|c|c|c|c|c|c|c|c|}
\hline \multirow{2}{*}{ Primary Fuel } & \multicolumn{11}{|c|}{ Regional Utility Consumption in Trillion of Btu/Yr } \\
\hline & New Eng. & $N Y / N J$ & Mid. Atl. & S. Atl. & Midwest & S. West & Central & N. Central & West & N. West & Total \\
\hline Coal & 405 & 1,444 & 2,245 & 4,915 & 5,636 & 4,312 & 1,460 & 836 & 583 & 215 & 22,051 \\
\hline Residual 011 & 439 & 166 & 266 & 251 & 225 & 18 & 26 & - & 1,367 & - & 2,758 \\
\hline D-stillate $0 i 1$ & 27 & 42 & 38 & 27 & 27 & 56 & 23 & - & 170 & - & 410 \\
\hline Natural Gas & - & - & - & - & 24 & 446 & 40 & - & - & - & 510 \\
\hline Uranium Fuël & 515 & 931 & 1,139 & 2,732 & 1,850 & 786 & 266 & 23 & 683 & 504 & 9,428 \\
\hline Total & 1,386 & 2,583 & 3,588 & $7 ; 925$ & 7,762 & 5,618 & 1,815 & 859 & 2,802 & 719 & 35,157 \\
\hline
\end{tabular}

Source: 1990 forecast data were obtained from supporting computer runs to Analysis Report, Energy Supply \& Demand in the Midterm: 1985, 1990, 1995, Apri1 1979, D0E/EIA-0102/52. 
EXHIBIT A-6

Summary of Forecasted Energy

Source Inputs to Region 1

New England

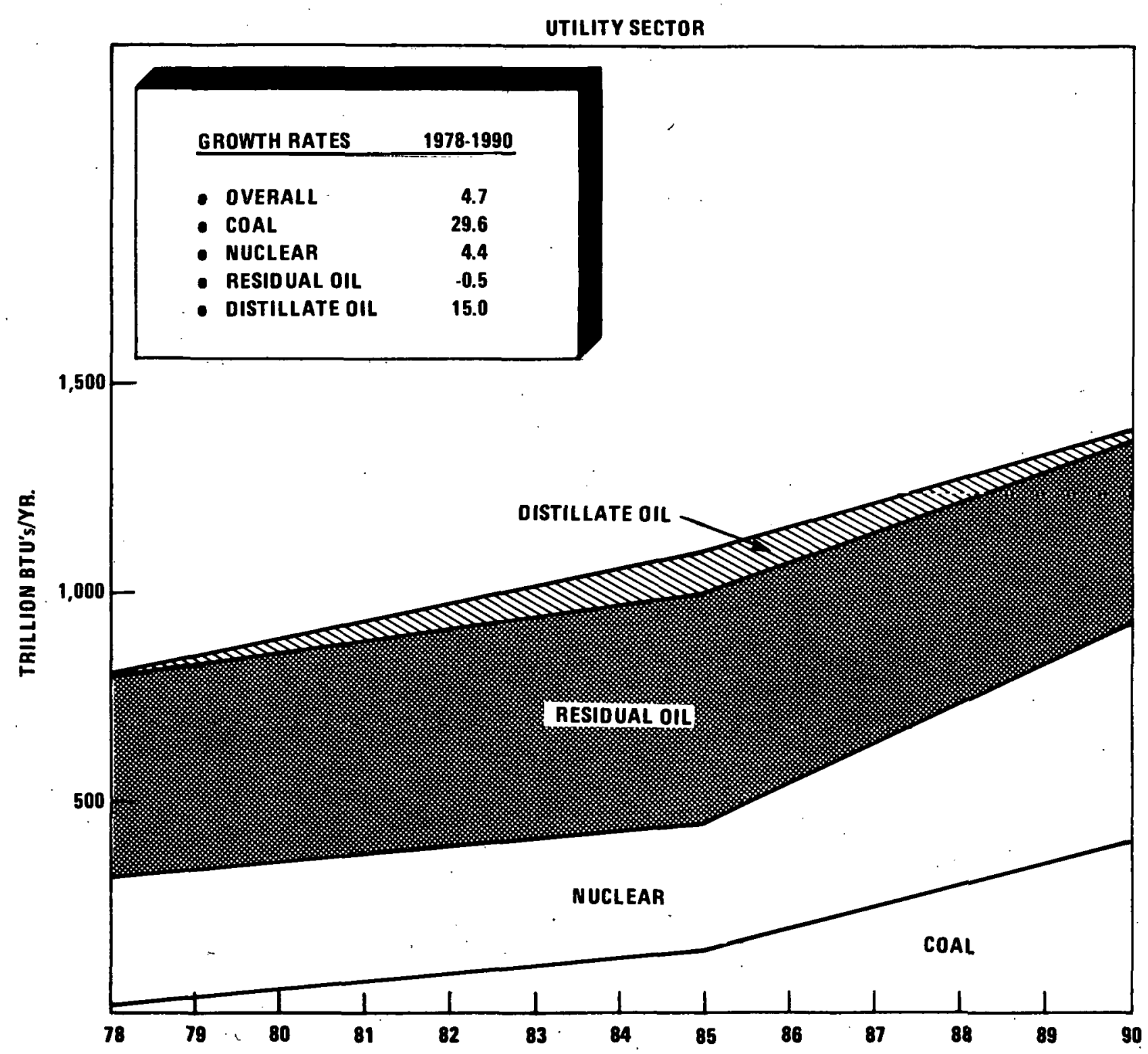

SOURCE: (1) 1978 CONSUMPTION DATA ARE PRELIMINARY ESTIMATES SUPPLIED TO BOOZ, ALLEN BY THE COAL \& ELECTRIC POWER ANALYSIS DIVISION, BUREAU OF APPLIED ANALYSIS AT DOE.

(2) 1985 \& 1990 FORECAST DATA WERE OBTAINED FROM SUPPORTING COMPUTER RUNS TO ANALYSIS REPORT, ENERGY SUPPLY \& DEMANDS IN THE MIDTERM: 1985, 1990, 1995, APRIL 1979, DOE/EIA-0102/52. 


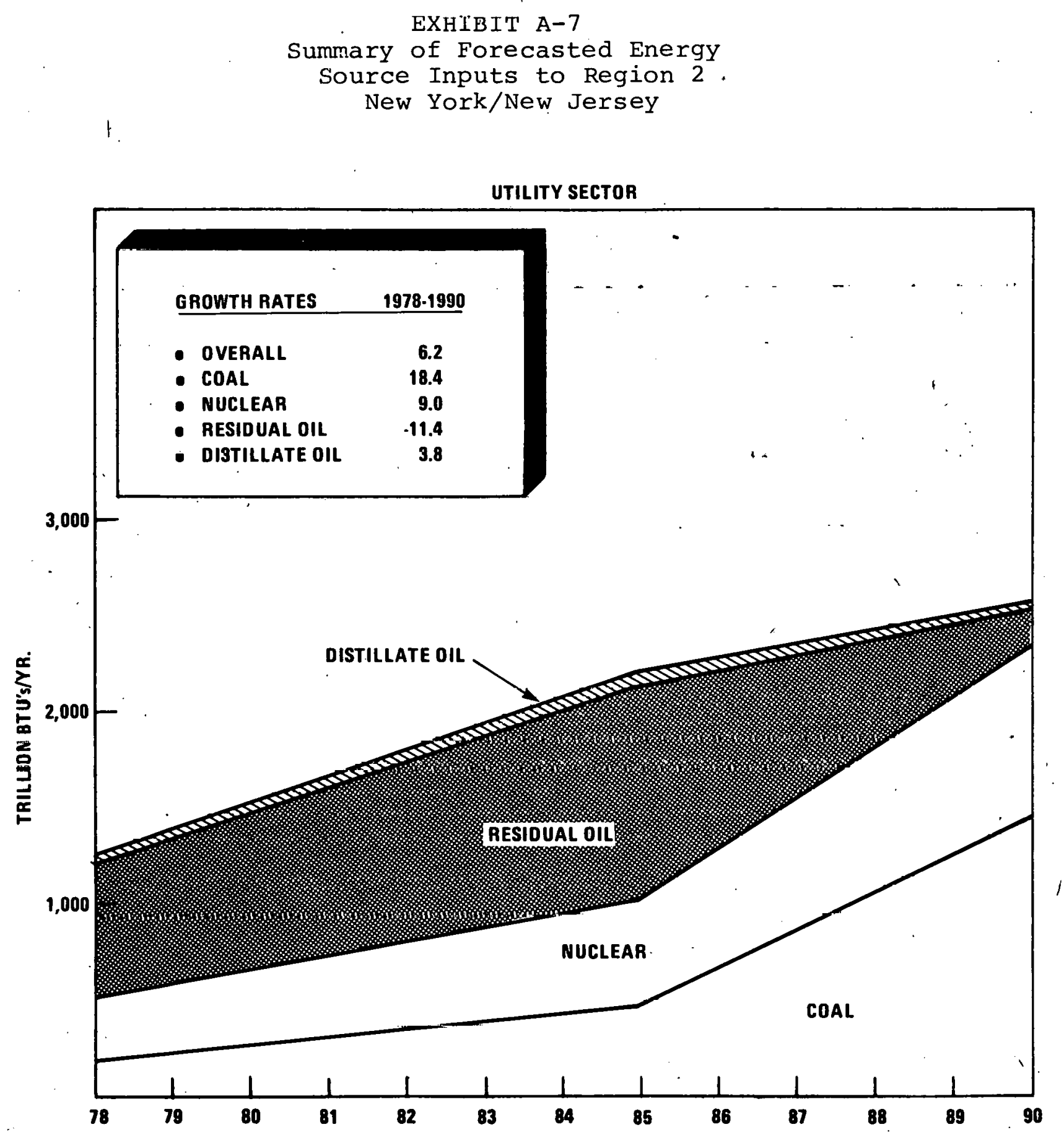

SOURCE: (1) 1978 CONSUMPTION DATA ARE PRELIMINARY ESTIMATES SUPPLIED TO BOOZ, ALLEN BY THE COAL \& ELECTRIC POWER ANALYSIS DIVISION, BUREAU OF APPLIED ANALYSIS AT DOE.

(2) 1985 \& 1990 FORECAST DATA WERE OBTAINED FROM SUPPORTING COMPUTER RUNS TO ANALYSIS REPORT, ENERGY SUPPLY \& DEMANDS IN THE MIDTERM: 1985, 1990, 1995, APRIL 1979, DOE/EIA-0102/52. 


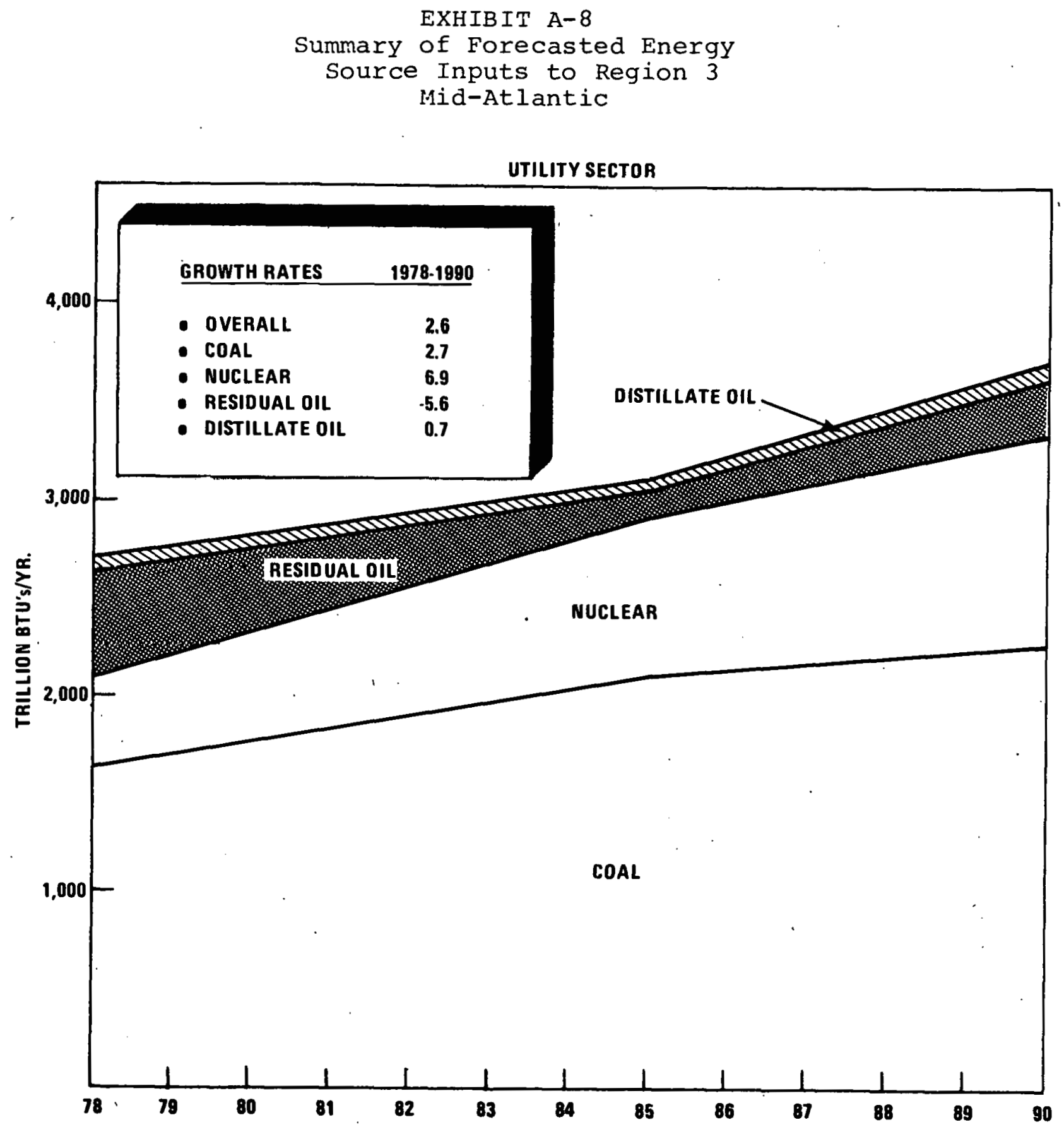

SO URCE: (1) 1978 CONSUMPTION DATA ARE PRELIMINARY ESTIMATES SUPPLIEO TO BOOZ, ALLEN BY THE COAL \& ELECTRIC POWER ANALYSIS DIVISION, BUREAU OF APPLIED ANALYSIS AT DOE.

(2) 1985 \& 1990 FORECAST DATA WERE OBTAINED FROM SUPPORTING COMPUTER RUNS TO ANALYSIS REPORT, ENERGY SUPPLY \& DEMANDS IN THE MIDTERM: 1985, 1990, 1995, APRIL 1979. DOE/EIA-0102/52. 


\section{EXHIBIT A-9}

Summary of Forecasted Energy

Source Inputs to Region 4

South Atlantic

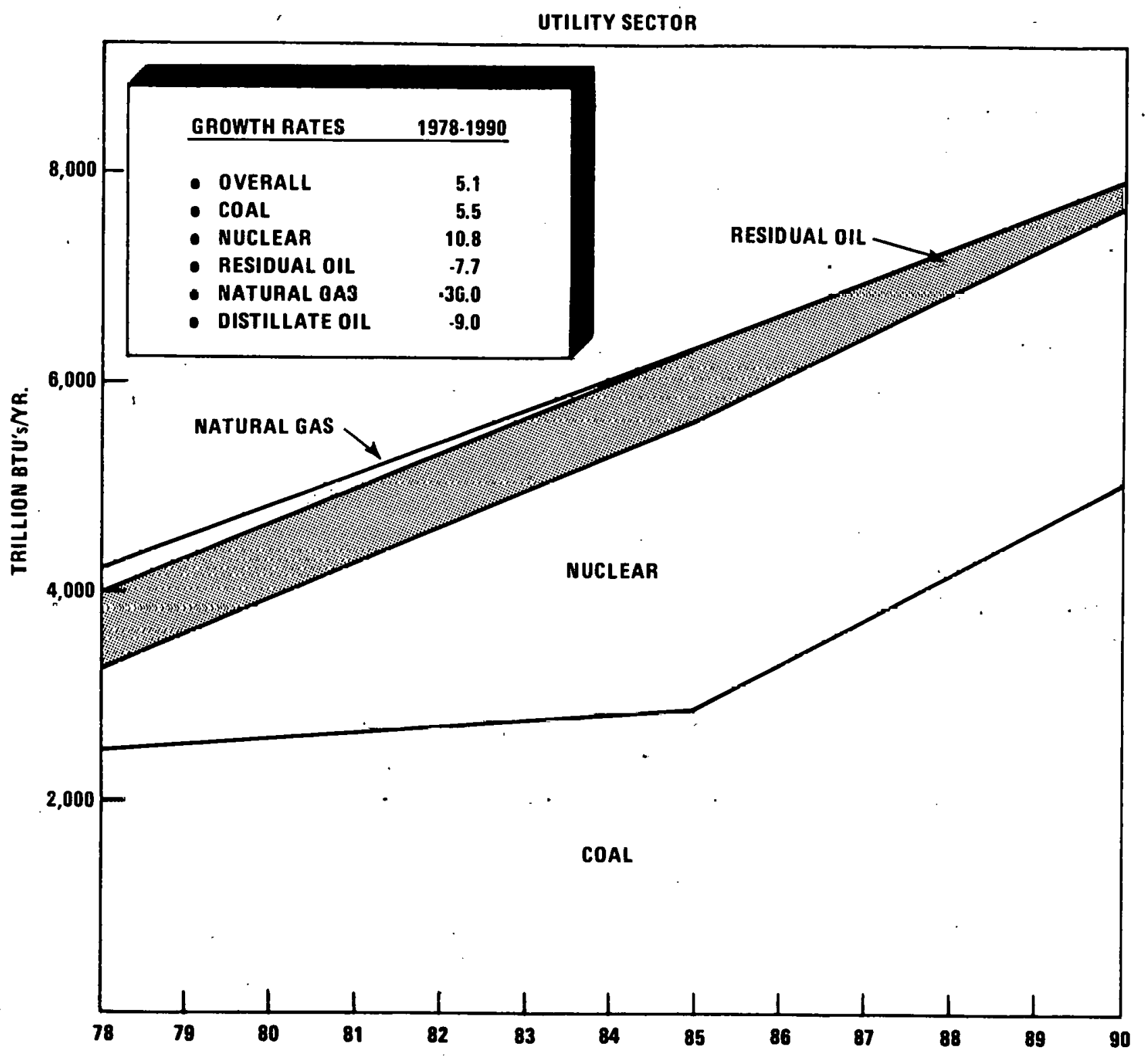

SOÚCE: (1) 1978 CONSUMPTION OATA ARE PRELIMINARY ESTIMATES SUPPLIED TO BOOZ, ALLEN BY THE COAL \& ELECTRIC POWER ANALYSIS DIVISION, BUREAU OF APPLIED ANALYSIS AT DOE.

(2) 1985 \& 1990 FORECAST DATA WERE OBTAINED FROM SUPPORTING COMPUTER RUNS TO ANALYSIS REPORT, ENERGY SUPPLY \& DEMANDS IN THE MIDTERM: 1985, 1990, 1995, APRIL 1979, DOE/EIA-0102/52. 
EXH IBIT A-10

Summary of Forecasted Energy
Source Inputs to Region 5
Midwest

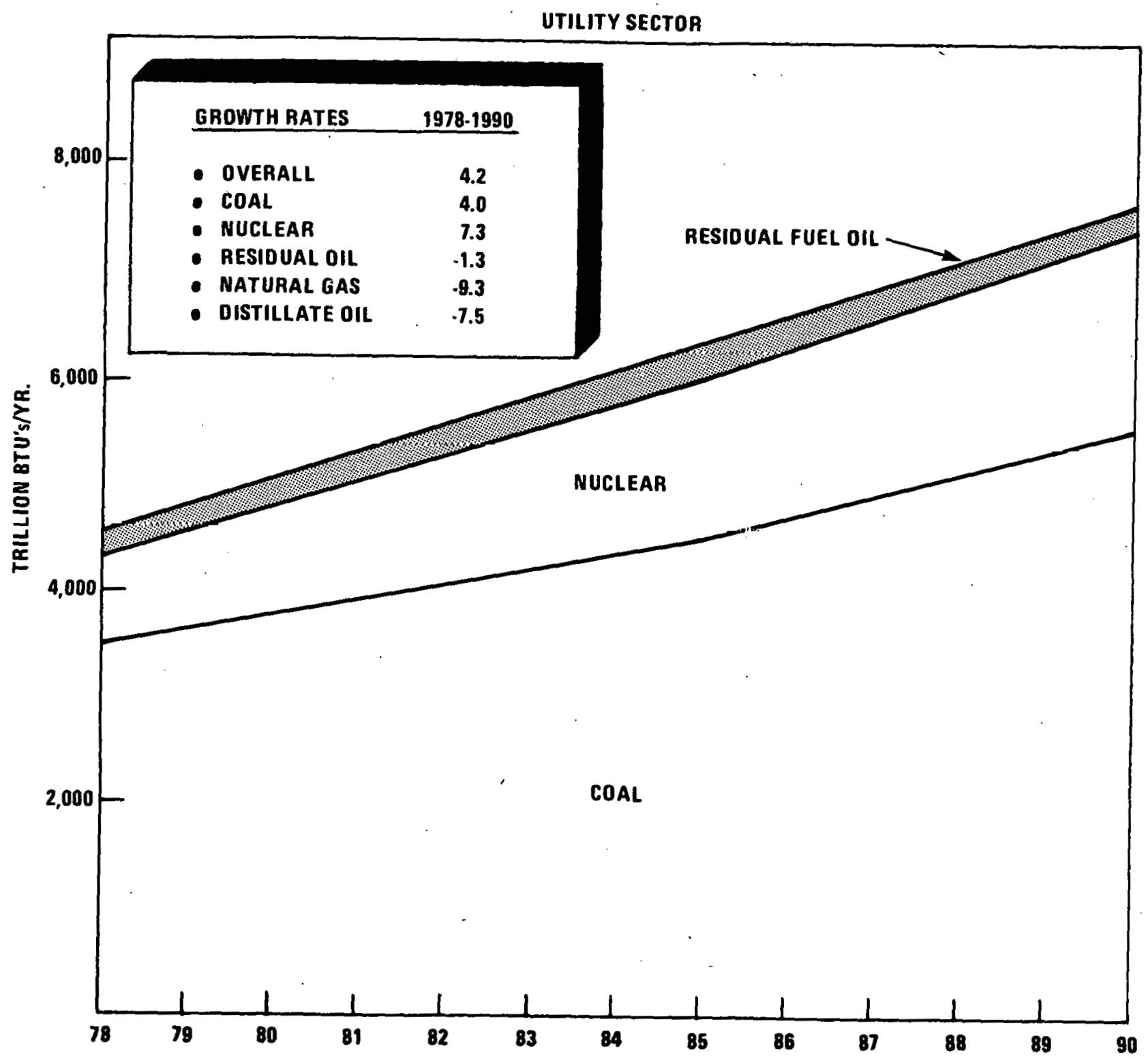

SOURCE: (1) 1978 CONSUMPTION DATA ARE PRELIMINARY ESTIMATES SUPPLIED TO BOOZ, ALLEN BY THE COAL \& ELECTRIC POWER ANALYSIS DIVISION, BUREAU OF APPLIEO ANALYSIS AT DOE.

(2) $1985 \& 1990$ FORECAST DATA WERE OBTAINED FROM SUPPORTING COMPUTER RUNS TO ANAL YSIS REPOAT, ENERGY SUPPLY \& DEMANDS SI THE MIOTERM: 1985, 1990, 1995, APRIL 1979, DOE/EIA-0102/52. 
EXHIBIT A-11

Summary of Forecasted Energy

Source Inputs to Region 6

Southwest

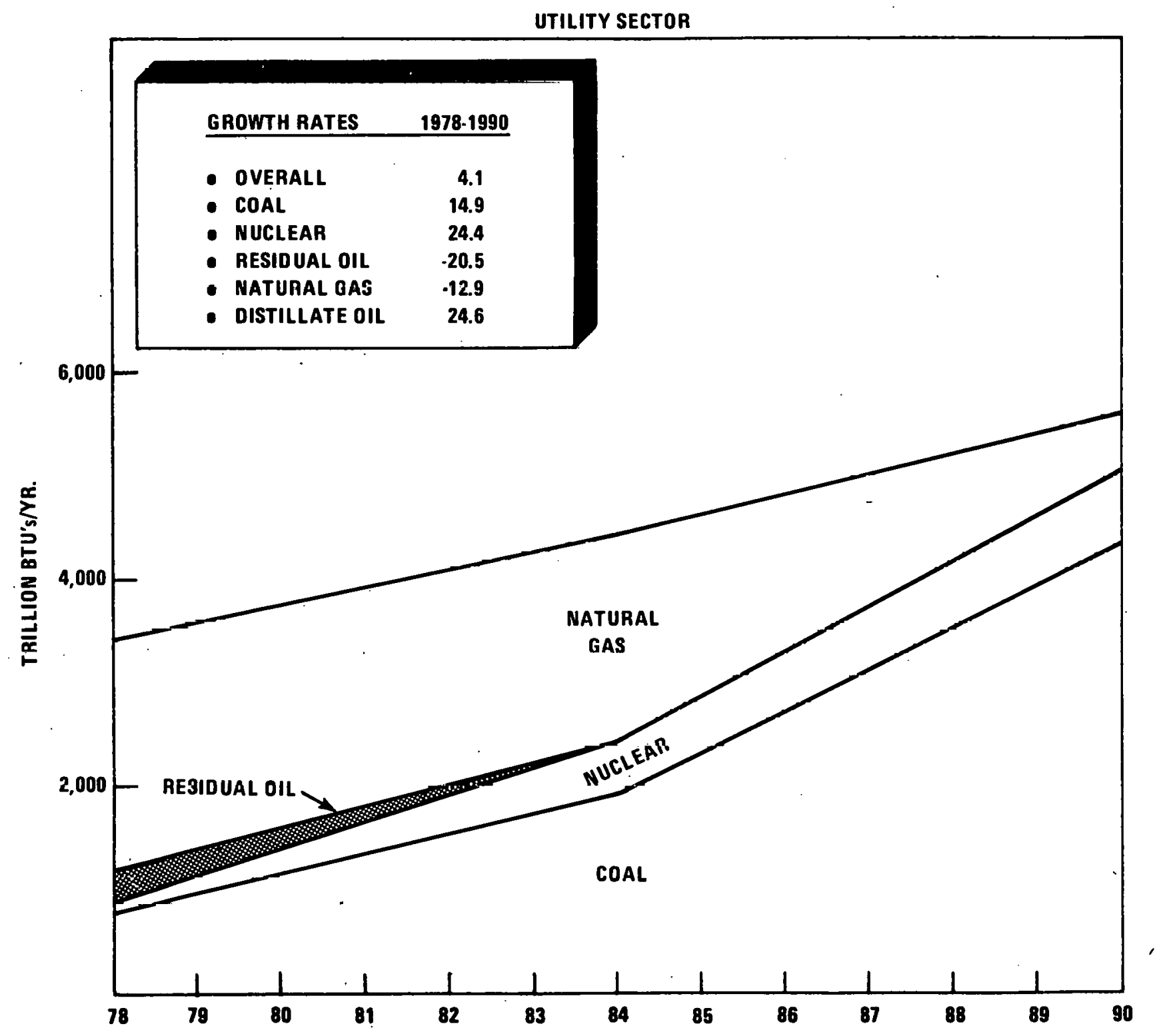

SOURCE: (1) 1978 CONSUMPTION DATA ARE PRELIMINARY ESTIMATES SUPPLIED TO BOOZ, ALLEN BY THE COAL \& ELECTRIC POWER ANALYSIS DIVISION, B UREAU OF APPLIED ANALYSIS AT DOE.

(2) 1985 \& 1990 FORECAST DATA WERE OBTAINED FROM SUPPORTING COMPUTER RUNS TO ANALYSIS REPORT, ENERGY SUPPLY \& DEMANDS IN THE MIDTERM: 1985, 1990, 1995, APRIL 1979, DOE/EIA.0102/52. 
EXHIBIT A-12

Summary of Forecasted Energy

Source Inputs to Region 7

Central

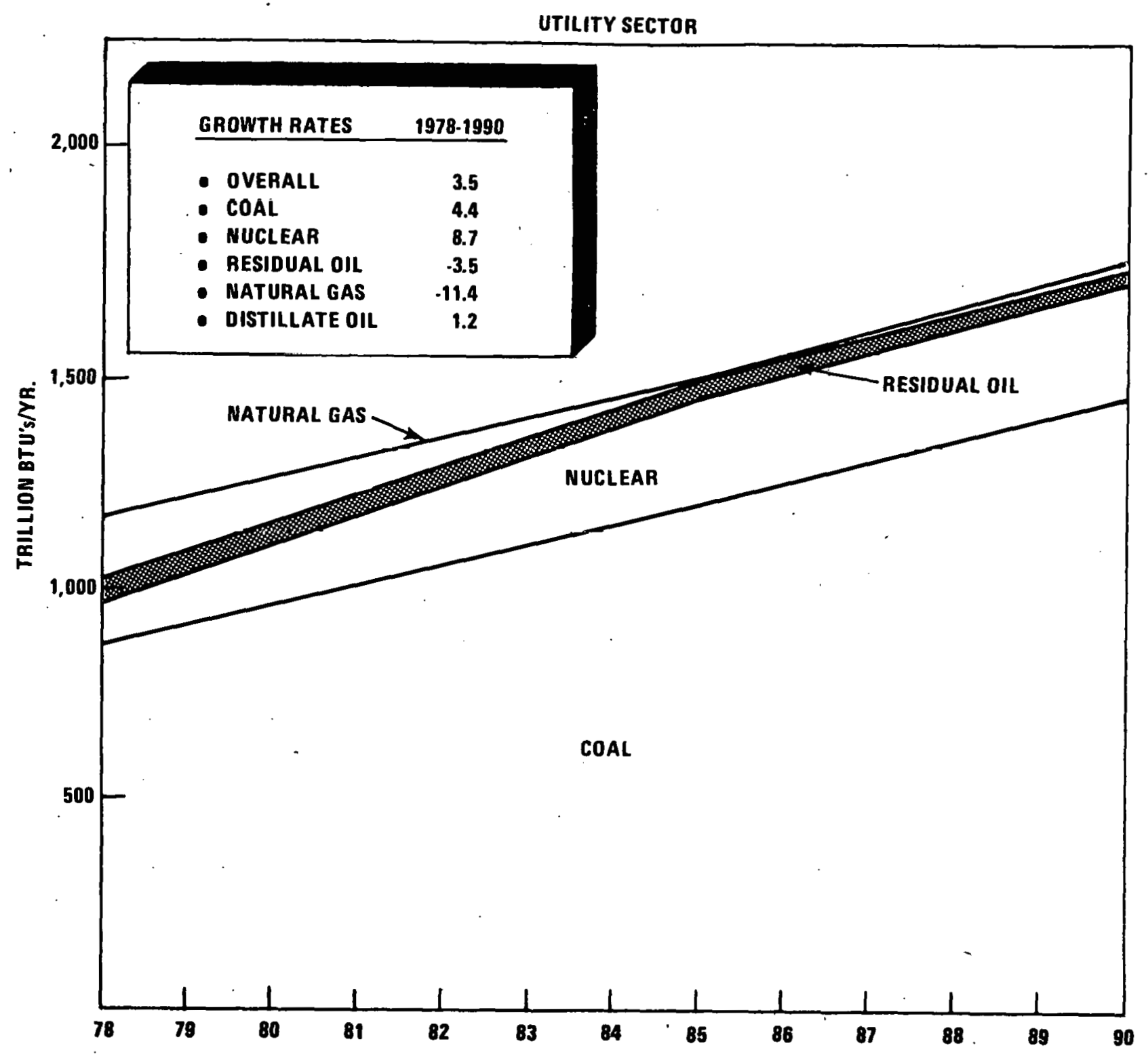

SOURCE: (1) 1978 CONSUMPTION DATA ARE PRELIMINARY ESTIMATES SUPPLIED TO BOOZ, ALLEN BY THE COAL \& ELECTRIC POWER ANALYSIS DIVISION, BUREAU DF APPLIED ANALYSIS AT DOE.

(2) $1985 \& 1990$ FORECAST DATA WERE OBTAINED FROM SUPPORTING COMPUTER RUNS TO ANALYSIS REPORT, ENERGY SUPPLY \& DEMANDS IN THE MIDTEBM: 1985, 1990, 1995,
APRIL 1979, DOE/EIA-0102/52. 
EXHIBIT A-13

Summary of Forecasted Energy

Source Inputs to Region 8

North Central

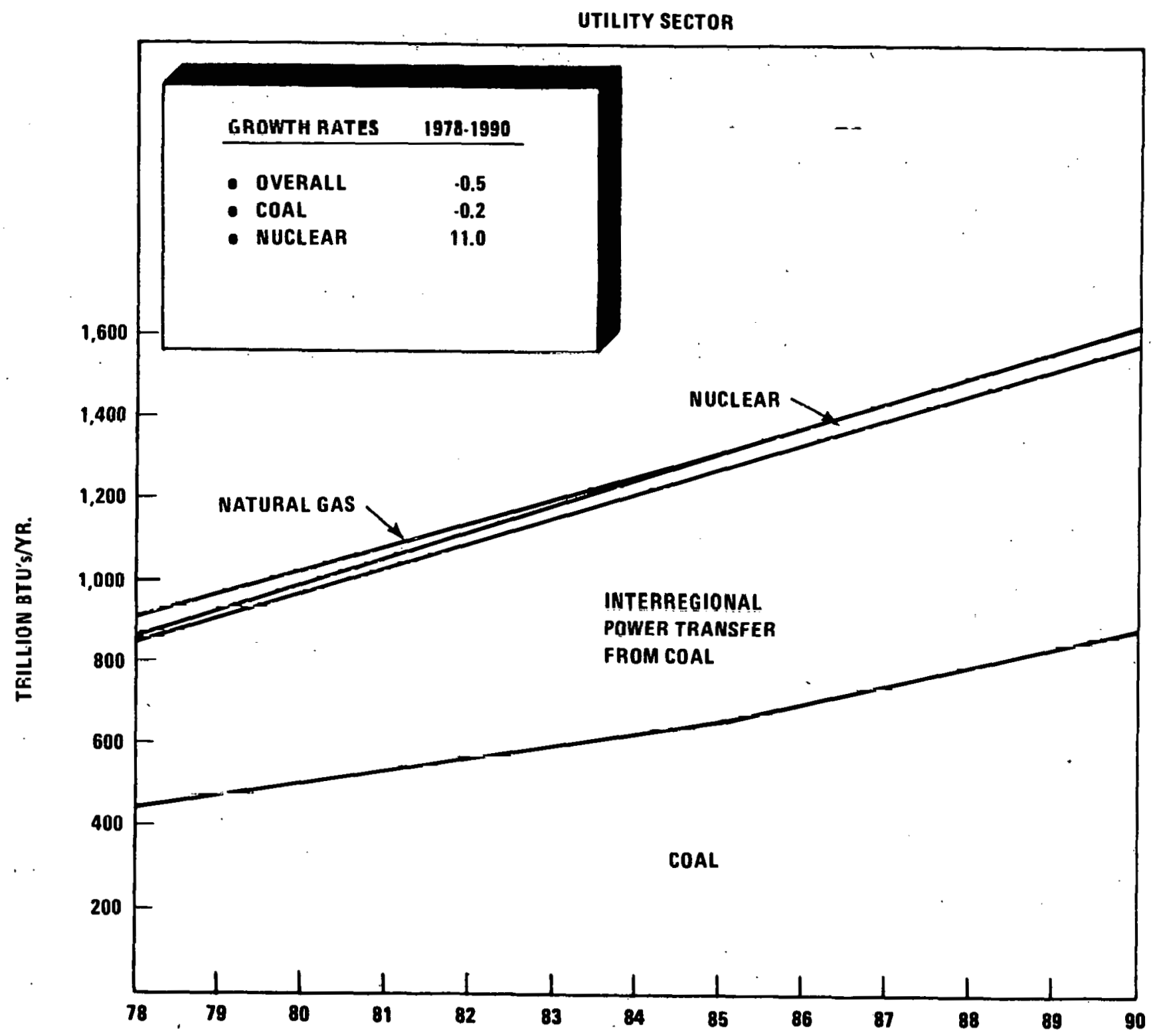

SOURCE: (1) 1978 CONSUMPTION DATA ARE PRELIMIMARY ESTIMATES SUPPLIED TO BO0Z, ALLEN BY THE COAL \& ELECTRIC POWER ANALYSIS DIVISION, BUREAU OF APPLIED ANALYSIS AT DOE.

(2) 1985 \& 1990 FORECAST DATA WERE OBTAINED FROM SUPPORTING COMPUTER RUNS TO ANALYSIS REPORT, ENERGY SUPPLY \& DEMANDS IN THE MIDTERM: 1985, 1990, 1995, APRIL 1979, DOE/EIA-0102/62. 


\title{
EXHIBIT A-14
}

\author{
Summary of Forecasted Energy \\ Source Inputs to Region 9 \\ West
}

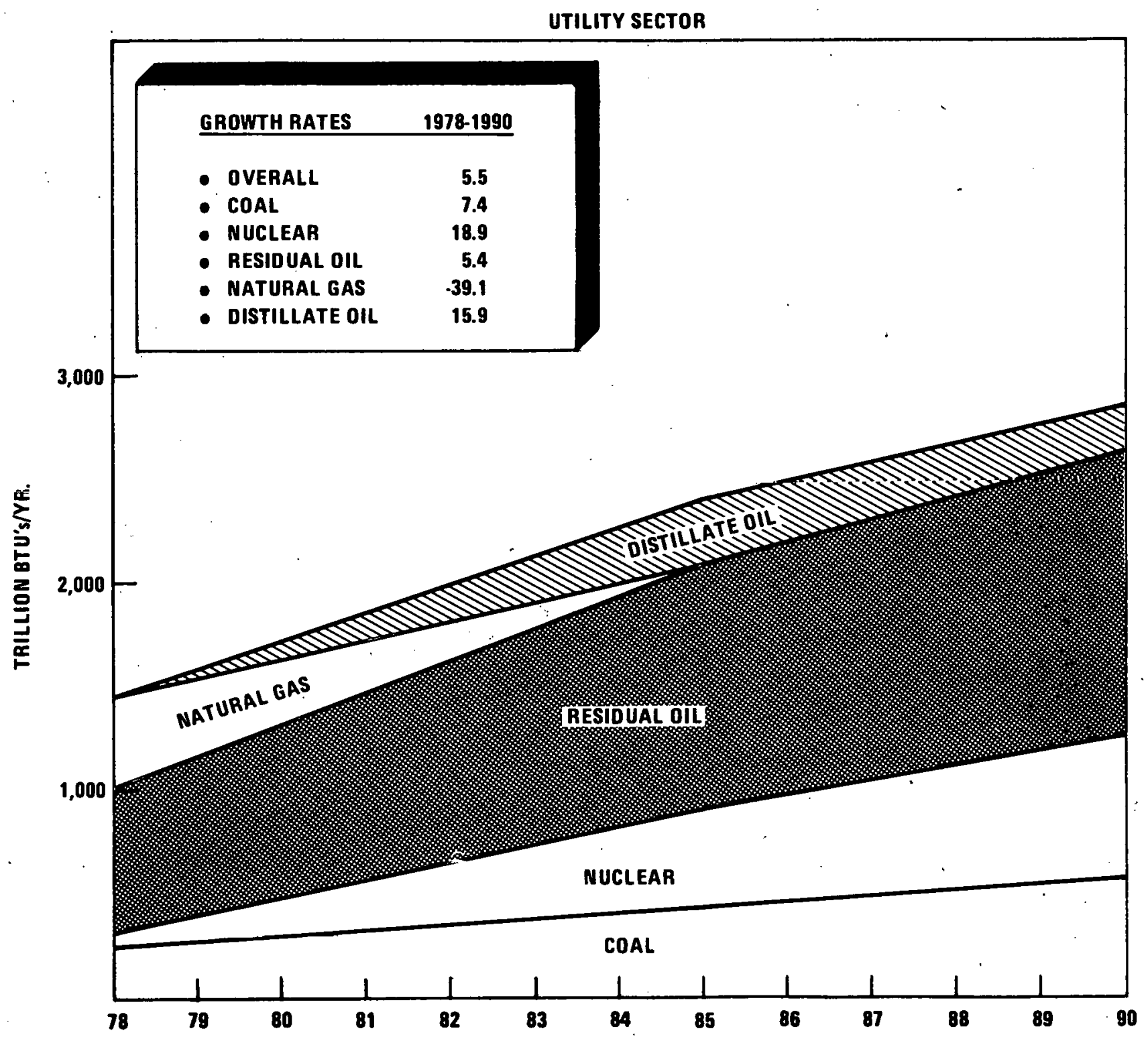

SO URCE: (1) 1978 CONSUMPTION DATA ARE PRELIMINARY ESTIMATES SUPPLIED TO BOOZ, ALLEN BY THE COAL \& ELECTRIC POWER ANALYSIS DIVISION, BUREAU OF APPLIED ANALYSIS AT DOE.

(2) 1985 \& 1990 FORECAST DATÁ WERE OBTAINED FROM SUPPORTING COMPUTER RUNS TO ANALYSIS REPORT, ENERGY SUPPLY \& DEMANDS IN THE MIDTERM: 1985, 1990, 1995, APRIL 1979, DOE/EIA-0102/52. 
EXHIBIT A-15

Summary of Forecasted Energy
Source Inputs to Region 10
Northwest

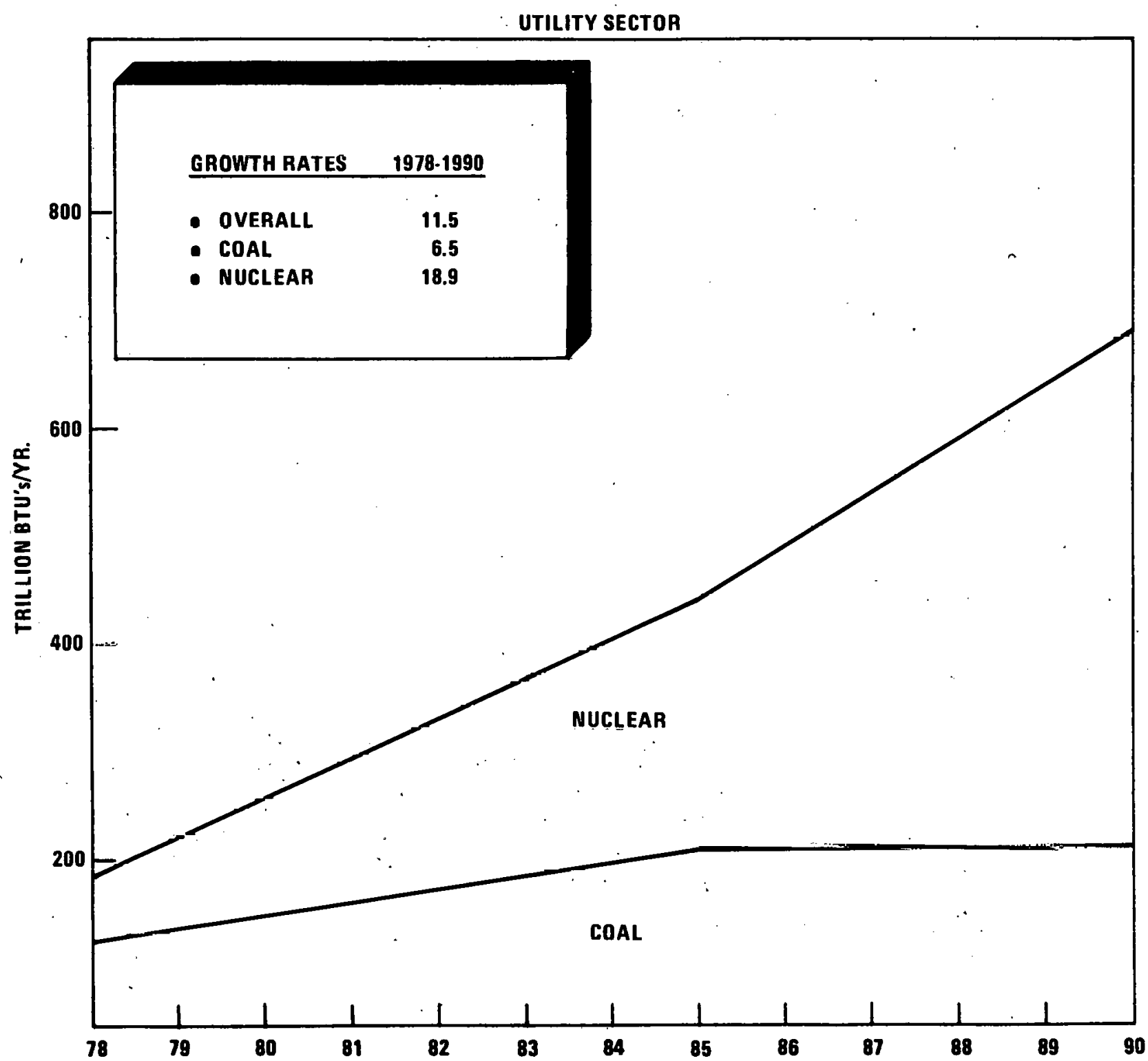

SOURCE: (1) 1978 CONSUMPTION DATA ARE PRELIMINARY ESTIMATES SUPPLIED TO BOOZ, ALLEN BY THE COAL \& ELECTRIC POWER ANALYSIS DIVISION, BUREAU OF APPLIED ANALYSIS AT DOE.

(2) 1985 \& 1990 FORECAST DATA WERE OBTAINED FROM SUPPORTING COMPUTER RUNS TO ANALYSIS REPORT, ENERGY SUPPLY \& DEMANDS IN THE MIDTERM: 1985, 1990, 1995, APRIL 1979, DOE/EIA-0102/52. 
ELECTRIC UTILITY CAPACITY EXPANSION FORECASTS 
EXH IBIT A-16

National Electricity Generation Forecast 1985

\begin{tabular}{|c|c|c|c|c|c|c|c|c|}
\hline \multirow{3}{*}{$\begin{array}{l}\text { Resource } \\
:\end{array}$} & \multicolumn{8}{|c|}{ Capacity in Gigawatts } \\
\hline & \multicolumn{2}{|c|}{ Base } & \multicolumn{2}{|c|}{ Intermediate } & \multicolumn{2}{|c|}{ Peak } & \multicolumn{2}{|c|}{ Total } \\
\hline & Existing & New & Existing & New & Existing & New & Existing & New \\
\hline Nuclear & 46.0 & 55.7 & - & - & - & - & 46.0 & 55.7 \\
\hline Coal With Scrubbers & 10.8 & 26.2 & 2.6 & 2.2 & 0.2 & - & 13.6 & 28.4 \\
\hline Coal Without Scrubbers & 177.3 & 41.3 & 16.0 & 1.7 & 2.0 & - & 195.3 & 43.0 \\
\hline Distillate Turbines & - & - & - & 0.3 & 11.1 & 7.7 & 11.1 & 8.0 \\
\hline Combined Cycle-Distillate & 1.3 & 4.0 & - & - & 0.5 & 0.1 & 1.8 & 4.1 \\
\hline Gas Turbines & - & - & - & - & 2.2 & - & 2.2 & - \\
\hline Gas Steam & 24.0 & 0.7 & 9,5 & - & 11.1 & 0.1 & $\angle 4.6$ & 0.8 \\
\hline Residual (0il-Steam) & 48.0 & 3.6 & 4.6 & 0.7 & 28.4 & 3.1 & 81.0 & 7.4 \\
\hline Hydro & 23.7 & 2.1 & 20.3 & 0.6 & 19.4 & - & 63.4 & 2.7 \\
\hline Pumped Storage & - & - & - & - & 9.9 & 10.7 & 9.9 & 10.4 \\
\hline $\begin{array}{l}\text { Solar (including hydro- } \\
\text { thermal, solar thermal, } \\
\text { photovoltaics, wind, } \\
\text { biomass; and ocean } \\
\text { thermal }\end{array}$ & - & 2.3 & - & - & - & - & - & 2.8 \\
\hline Total & 330.4 & 136.4 & 53.0 & 5.5 & 84.8 & 21.7 & 468.9 & 163.3 \\
\hline
\end{tabular}

Source: 1985 forecast data were obtainec from supporting computer runs to Analysis Report, Energy Supply \& Demand in the Midterm: 1985, 1990, 1995, Apri1 1979, DOE/EIA-0102/52. 
EXHIBIT $A-17$

National Electricity Generation Forecast 1990

\begin{tabular}{|c|c|c|c|c|c|c|c|c|}
\hline \multirow{3}{*}{ Resource } & \multicolumn{8}{|c|}{ Capacity in Gigawatts } \\
\hline & \multicolumn{2}{|c|}{ Base } & \multicolumn{2}{|c|}{ Intermediate } & \multicolumn{2}{|c|}{ Peak } & \multicolumn{2}{|c|}{ Total } \\
\hline & Existing & New & Existing & New & Existing & New & Existing & New \\
\hline Nuclear & 46.0 & 99.9 & - & - & - & - & 46.0 & 99.9 \\
\hline Coal With Scrubbers & 10.8 & 140.5 & 3.5 & 1.0 & - & - & 14.3 & 141.5 \\
\hline Coal Without Scrubbers & 176.7 & 46.1 & 13.5 & - & 4.9 & - & 195.1 & 46.1 \\
\hline Distillate Turbines & - & - & - & - & 3.3 & 14.3 & 3.3 & 14.3 \\
\hline Combined Cycle-Distillate & 1.7 & 4.0. & 0.8 & - & 0.6 & 0.1 & 3.1 & 4.1 \\
\hline Gas. Turbines & - & - & - & - & 4.3 & - & 4.3 & - \\
\hline Gas Steam & - & - & 3.6 & - & 12.9 & - & 16.5 & - \\
\hline Residual (0il-Steam) & 28.3 & 3.6 & 5.8 & 1.7 & 23.6 & 2.6 & 57.7 & 7.9 \\
\hline Hydro & 23.6 & 4.6 & 17.1 & 1.8 & 22.8 & 0.3 & 63.5 & 6.7 \\
\hline Pumped Storage & - & - & - & - & 9.7 & 18.0 & 9.7 & 18.0 \\
\hline $\begin{array}{l}\text { Solar (including hydro- } \\
\text { thermal, solar thermal, } \\
\text { photovoltaics, wind, } \\
\text { biomass, and ocean } \\
\text { thermal }\end{array}$ & - & 5.1 & - & - & - & - & - & 5.1 \\
\hline Total & 287.1 & $303.8^{\prime}$ & 44.3 & 4.5 & 82.1 & 35.3 & 413.5 & 343.6 \\
\hline
\end{tabular}

Source: 1990 forecast data were obtained from supporting computer runs to Analysis Report, Energy Supply \& Demand in the Midterm: 1985, 1990, 1995, Apri1 1979, DOE/EIA-0102/52. 
ELECTRIC UTILITY OIL AND GAS STEAI PLANT IIARKET DATA 
EXHIBIT A-18

Total Market Size of Existing Oil and Gas Steam Plants Tabulated by DOE Recion

\begin{tabular}{|c|c|c|c|c|c|c|c|c|c|c|c|}
\hline \multirow[b]{2}{*}{ Flant Type } & \multicolumn{11}{|c|}{ Market Size (MW) } \\
\hline & New Eng. & $\mathrm{NY} / \mathrm{NJ}$ & Mid. Atl. & S. Atl. & Midwest & S. West & Central & N. Central & West & N. West & Totá1 \\
\hline (1ij) Steam & 10,392 & 22,786 & 14,417 & 18,877 & 9,413 & 4,243 & 385 & 302 & 25,047 & 223 & 106,085 \\
\hline Gas Steam & - & 65 & 10 & 1,303 & 369 & 57,961 & 4,941 & 301 & 1,232 & 51 & 66,233 \\
\hline Total & 10,392 & 22,851 & $14: 42 ?$ & 20,180 & 9,782 & 62,204 & 5,326 & 503 & 26,279 & 274 & 172,318 \\
\hline
\end{tabular}

Mote: (1) Includes all plant size, from 1 to 1,028 MW.

(2) Includes plant commercial start dates, 1908 through 1977.

Source: DOE Inventory of Powerplants, July 1978 
EXHIBIT A-19

Total Market Size of Existing Oil and Gas Steam Plants by Fuel and Timeframe

\begin{tabular}{|c|c|c|c|c|c|c|c|}
\hline \multirow{2}{*}{ Time frame } & \multirow{2}{*}{ Region } & \multicolumn{2}{|c|}{$0 i 1$} & \multicolumn{2}{|r|}{ Gas } & \multicolumn{2}{|c|}{ Total } \\
\hline & & No. & MW & No. & $\mathrm{MW}$ & No. & MW \\
\hline $\begin{array}{l}1978-1968 \\
1967-1958 \\
1957-1948 \\
1947-1938 \\
1937-0 \\
\text { Total }\end{array}$ & $\stackrel{1}{\text { (Wew Eng.) }}$ & $\begin{array}{r}11 \\
46 \\
38 \\
14 \\
10 \\
119\end{array}$ & $\begin{array}{r}4,573 \\
3,366 \\
1,903 \\
361 \\
189 \\
10,392\end{array}$ & $\begin{array}{l}- \\
- \\
- \\
-\end{array}$ & $\begin{array}{l}- \\
- \\
- \\
-\end{array}$ & $\begin{array}{r}11 \\
46 \\
38 \\
14 \\
10 \\
119\end{array}$ & $\begin{array}{r}4,573 \\
3,366 \\
1,903 \\
361 \\
189 \\
10,393\end{array}$ \\
\hline $\begin{array}{l}1978-1968 \\
1967-1958 \\
1957-1948 \\
1947-1938 \\
1937-0 \\
\text { Total }\end{array}$ & $\frac{2}{(N Y / N J)}$ & $\begin{array}{r}17 \\
41 \\
47 \\
10 \\
27 \\
137\end{array}$ & $\begin{array}{r}7,161 \\
9,181 \\
4,717 \\
539 \\
1,188 \\
22,786\end{array}$ & $\begin{array}{l}- \\
- \\
1 \\
- \\
1\end{array}$ & $\begin{array}{l}- \\
- \\
- \\
65 \\
65 \\
65\end{array}$ & $\begin{array}{r}17 \\
41 \\
47 \\
11 \\
2 ? \\
138\end{array}$ & $\begin{array}{r}7,161 \\
9,181 \\
4,717 \\
604 \\
1,188 \\
22,851 \\
\end{array}$ \\
\hline $\begin{array}{l}1978-1968 \\
1967-1958 \\
1957-1948 \\
1947-1938 \\
1937-0 \\
\text { Total } \\
\end{array}$ & $\frac{3}{(M i d-A t l .)}$ & $\begin{array}{l}16 \\
14 \\
35 \\
17 \\
15 \\
97 \\
\end{array}$ & $\begin{array}{r}7,835 \\
2,013 \\
2,994 \\
1,018 \\
557 \\
14,417 \\
\end{array}$ & $\begin{array}{l}- \\
- \\
- \\
- \\
1 \\
1\end{array}$ & $\begin{array}{l}- \\
- \\
- \\
10 \\
10\end{array}$ & $\begin{array}{l}16 \\
14 \\
35 \\
17 \\
16 \\
98 \\
\end{array}$ & $\begin{array}{r}7,835 \\
2,013 \\
2,994 \\
1,018 \\
567 \\
14,427 \\
\end{array}$ \\
\hline $\begin{array}{l}1978-1968 \\
1967-1958 \\
1957-1948 \\
1947-1938 \\
1937-0 \\
\text { Total }\end{array}$ & ${ }^{4}{ }^{4}$ Atl) & $\begin{array}{r}27 \\
41 \\
49 \\
7 \\
1 \\
125 \\
\end{array}$ & $\begin{array}{r}9,733 \\
6,609 \\
2,204 \\
271 \\
60 \\
18,877 \\
\end{array}$ & $\begin{array}{r}1 \\
7 \\
14 \\
3 \\
2 \\
27 \\
\end{array}$ & $\begin{array}{r}35 \\
495 \\
642 \\
108 \\
23 \\
1,303 \\
\end{array}$ & $\begin{array}{r}28 \\
48 \\
63 \\
10 \\
3 \\
152 \\
\end{array}$ & $\begin{array}{r}9,768 \\
7,104 \\
2,846 \\
379 \\
83 \\
20,180 \\
\end{array}$ \\
\hline $\begin{array}{l}1978-1968 \\
1967-1958 \\
1957-1948 \\
1947-1938 \\
1937-0 \\
\text { Total }\end{array}$ & $\begin{array}{c}5 \\
\text { (Midwest) }\end{array}$ & $\begin{array}{r}7 \\
11 \\
39 \\
41 \\
34 \\
132 \\
\end{array}$ & $\begin{array}{r}3,009 \\
1,250 \\
2,732 \\
1,452 \\
970 \\
9,413\end{array}$ & $\begin{array}{r}5 \\
4 \\
5 \\
4 \\
10 \\
28 \\
\end{array}$ & $\begin{array}{r}77 \\
69 \\
36 \\
48 \\
139 \\
369 \\
\end{array}$ & $\begin{array}{r}12 \\
15 \\
44 \\
45 \\
44 \\
160\end{array}$ & $\begin{array}{l}3,086 \\
1,319 \\
2,768 \\
1,500 \\
1,109 \\
9,782\end{array}$ \\
\hline $\begin{array}{l}1978-1968 \\
1967-1958 \\
1957-1948 \\
1947-1938 \\
1937-0 \\
\text { Total }\end{array}$ & (5. West) & $\begin{array}{r}7 \\
1 \\
12 \\
1 \\
0 \\
21\end{array}$ & $\begin{array}{r}, 401 \\
50 \\
758 \\
34 \\
0 \\
4,243 \\
\end{array}$ & $\begin{array}{r}95 \\
124 \\
150 \\
32 \\
38 \\
439 \\
\end{array}$ & $\begin{array}{r}29,103 \\
19,535 \\
8,030 \\
626 \\
667 \\
57,961 \\
\end{array}$ & $\begin{array}{r}102 \\
125 \\
162 \\
33 \\
38 \\
460 \\
\end{array}$ & $\begin{array}{r}32,504 \\
19,585 \\
8,788 \\
660 \\
667 \\
62,204 \\
\end{array}$ \\
\hline $\begin{array}{l}1978-1968 \\
1967-1958 \\
1957-1948 \\
1947-1938 \\
1937-0 \\
\text { Total }\end{array}$ & $\begin{array}{c}7 \\
\text { (Central) }\end{array}$ & $\begin{array}{r}0 \\
0 \\
13 \\
4 \\
7 \\
24 \\
\end{array}$ & $\begin{array}{r}0 \\
0 \\
233 \\
56 \\
96 \\
385\end{array}$ & $\begin{array}{r}10 \\
28 \\
68 \\
19 \\
18 \\
143 \\
\end{array}$ & $\begin{array}{r}1,083 \\
1,995 \\
1,447 \\
233 \\
183 \\
4,941\end{array}$ & $\begin{array}{r}10 \\
28 \\
81 \\
23 \\
25 \\
167\end{array}$ & $\begin{array}{r}1,083 \\
1,995 \\
1,680 \\
289 \\
279 \\
5,326\end{array}$ \\
\hline $\begin{array}{l}1978-1968 \\
1967-1958 \\
1957-1948 \\
1947-1938 \\
1937-0 \\
\text { Total }\end{array}$ & (N. Central) & $\begin{array}{l}0 \\
1 \\
4 \\
2 \\
1 \\
0\end{array}$ & $\begin{array}{r}0 \\
75 \\
194 \\
8 \\
25 \\
302\end{array}$ & $\begin{array}{r}2 \\
0 \\
9 \\
5 \\
10 \\
26 \\
\end{array}$ & $\begin{array}{r}41 \\
0 \\
108 \\
45 \\
107 \\
301 \\
\end{array}$ & $\begin{array}{r}2 \\
1 \\
13 \\
7 \\
11 \\
34 \\
\end{array}$ & $\begin{array}{r}41 \\
75 \\
302 \\
53 \\
132 \\
603 \\
\end{array}$ \\
\hline $\begin{array}{l}1979-1968 \\
1967-1958 \\
1957-1948 \\
1947-1938 \\
1937-0 \\
\text { Totals }\end{array}$ & $\begin{array}{c}9 \\
\text { (West) }\end{array}$ & $\begin{array}{r}15 \\
70 \\
79 \\
16 \\
7 \\
187\end{array}$ & $\begin{array}{r}4,196 \\
13,332 \\
6,866 \\
437 \\
216 \\
25,042\end{array}$ & $\begin{array}{r}4 \\
4 \\
2 \\
0 \\
0 \\
10\end{array}$ & $\begin{array}{r}827 \\
290 \\
115 \\
0 \\
0 \\
1,232\end{array}$ & $\begin{array}{r}19 \\
79 \\
81 \\
16 \\
7 \\
197 \\
\end{array}$ & $\begin{array}{r}5,023 \\
13,622 \\
6,981 \\
437 \\
216 \\
26,279\end{array}$ \\
\hline $\begin{array}{l}1978-1968 \\
1967-1958 \\
1957-1948 \\
1947-1938 \\
1937-0 \\
\text { Total }\end{array}$ & (N. West) & $\begin{array}{r}0 \\
0 \\
1 \\
0 \\
12 \\
13 \\
\end{array}$ & $\begin{array}{r}0 \\
0 \\
25 \\
0 \\
198 \\
223 \\
\end{array}$ & $\begin{array}{l}0 \\
1 \\
4 \\
0 \\
3 \\
8 \\
\end{array}$ & $\begin{array}{r}0 \\
5 \\
10 \\
0 \\
36 \\
51 \\
\end{array}$ & $\begin{array}{r}0 \\
1 \\
5 \\
0 \\
15 \\
21 \\
\end{array}$ & $\begin{array}{r}0 \\
5 \\
35 \\
0 \\
234 \\
274 \\
\end{array}$ \\
\hline $\begin{array}{l}\text { Grand Totals } \\
1978-1968 \\
1967-1958 \\
1957-1948 \\
1947-1938 \\
1937-0\end{array}$ & $\begin{array}{l}\text { All } 10 \\
\text { Regions }\end{array}$ & $\begin{array}{l}100 \\
225 \\
317 \\
112 \\
109\end{array}$ & $\begin{array}{r}39,908 \\
35,876 \\
22,626 \\
4,176 \\
3,499\end{array}$ & $\begin{array}{r}117 \\
168 \\
252 \\
64 \\
82\end{array}$ & $\begin{array}{r}31,166 \\
22,389 \\
10,388 \\
1,125 \\
1,165\end{array}$ & $\begin{array}{l}217 \\
393 \\
569 \\
176 \\
191\end{array}$ & $\begin{array}{r}71,074 \\
58,265 \\
33,014 \\
5,301 \\
4,665\end{array}$ \\
\hline \multicolumn{2}{|c|}{ Combined Totals } & 863 & 106,085 & 683 & 66,233 & 1,546 & 172,318 \\
\hline
\end{tabular}

Note: Includes all plant sizes.

Source: DOE Powerplant Listing, July 1978. 
EXHIBIT A-20

Total Market Size of Existing Oil and Gas Steam Plants by Fuel and Unit Size

\begin{tabular}{|c|c|c|c|c|c|c|c|}
\hline \multirow{2}{*}{$\underset{M W}{\text { Unit size }}$} & \multirow[b]{2}{*}{ Region } & \multicolumn{2}{|c|}{0 il } & \multicolumn{2}{|c|}{ Gas } & \multicolumn{2}{|c|}{ Total } \\
\hline & & No. & MW & No. & MW & No. & $M W$ \\
\hline $\begin{array}{l}0-100 \\
101-200 \\
201-400 \\
401+ \\
\text { Total } \\
\end{array}$ & 1 & $\begin{array}{r}92 \\
13 \\
7 \\
7 \\
119 \\
\end{array}$ & $\begin{array}{r}2,697 \\
1,743 \\
2,421 \\
3,531 \\
10,392 \\
\end{array}$ & $\begin{array}{l}0 \\
0 \\
0 \\
0 \\
0 \\
\end{array}$ & $\begin{array}{l}0 \\
0 \\
0 \\
0 \\
0 \\
\end{array}$ & $\begin{array}{r}92 \\
13 \\
7 \\
7 \\
119 \\
\end{array}$ & $\begin{array}{r}2,697 \\
1,743 \\
2,421 \\
3,531 \\
10,392 \\
\end{array}$ \\
\hline $\begin{array}{l}0-100 \\
101-200 \\
201-400 \\
400+ \\
\text { Total } \\
\end{array}$ & 2 & $\begin{array}{r}75 \\
29 \\
20 \\
13 \\
137 \\
\end{array}$ & $\begin{array}{r}3,863 \\
4,211 \\
6,775 \\
7,937 \\
22,786 \\
\end{array}$ & $\begin{array}{l}1 \\
0 \\
0 \\
0 \\
1 \\
\end{array}$ & $\begin{array}{r}65 \\
0 \\
0 \\
0 \\
65 \\
\end{array}$ & $\begin{array}{r}76 \\
29 \\
20 \\
13 \\
138 \\
\end{array}$ & $\begin{array}{r}3,928 \\
4,211 \\
6,775 \\
7,937 \\
22,851 \\
\end{array}$ \\
\hline $\begin{array}{l}0-100 \\
101=200 \\
201-400 \\
401+ \\
\text { Totals }\end{array}$ & 3 & $\begin{array}{r}60 \\
21 \\
7 \\
9 \\
97 \\
\end{array}$ & $\begin{array}{r}2,864 \\
3,353 \\
2,029 \\
6,171 \\
14,417 \\
\end{array}$ & $\begin{array}{l}1 \\
0 \\
0 \\
0 \\
1 \\
\end{array}$ & $\begin{array}{r}10 \\
0 \\
0 \\
0 \\
10 \\
\end{array}$ & $\begin{array}{r}61 \\
21 \\
7 \\
9 \\
98 \\
\end{array}$ & $\begin{array}{r}2,874 \\
3,35.3 \\
2,029 \\
6,171 \\
14,427 \\
\end{array}$ \\
\hline $\begin{array}{l}0-100 \\
101-200 \\
201-400 \\
401+ \\
\text { Total } \\
\end{array}$ & 4 & $\begin{array}{r}81 \\
15 \\
9 \\
20 \\
125 \\
\end{array}$ & $\begin{array}{r}3,447 \\
2,240 \\
2,403 \\
10,787 \\
18,877 \\
\end{array}$ & $\begin{array}{r}24 \\
2 \\
1 \\
0 \\
27 \\
\end{array}$ & $\begin{array}{r}844 \\
220 \\
239 \\
0 \\
1,303 \\
\end{array}$ & $\begin{array}{r}105 \\
17 \\
10 \\
20 \\
152 \\
\end{array}$ & $\begin{array}{r}4,291 \\
2,460 \\
2,642 \\
10,787 \\
20,180 \\
\end{array}$ \\
\hline $\begin{array}{r}0-100 \\
101-200 \\
201-400 \\
400+ \\
\text { Total } \\
\end{array}$ & 5 & $\begin{array}{r}114 \\
9 \\
4 \\
5 \\
132 \\
\end{array}$ & $\begin{array}{l}3,849 \\
1,426 \\
1,349 \\
2,789 \\
9,413 \\
\end{array}$ & $\begin{array}{r}28 \\
0 \\
0 \\
0 \\
28 \\
\end{array}$ & $\begin{array}{r}369 \\
0 \\
0 \\
0 \\
369 \\
\end{array}$ & $\begin{array}{r}142 \\
9 \\
4 \\
5 \\
160 \\
\end{array}$ & $\begin{array}{l}4,218 \\
1,426 \\
1,349 \\
2,789 \\
9,782 \\
\end{array}$ \\
\hline $\begin{array}{l}0-100 \\
101-200 \\
201-400 \\
400+ \\
\text { Total }\end{array}$ & 6 & $\begin{array}{r}12 \\
3 \\
0 \\
6 \\
6 \\
21 \\
\end{array}$ & $\begin{array}{r}573 \\
429 \\
0 \\
3,241 \\
4,243 \\
\end{array}$ & $\begin{array}{r}273 \\
78 \\
45 \\
43 \\
139 \\
\end{array}$ & $\begin{array}{r}9,385 \\
11,240 \\
13,141 \\
24,195 \\
57,961 \\
\end{array}$ & $\begin{array}{r}285 \\
81 \\
45 \\
49 \\
460 \\
\end{array}$ & $\begin{array}{r}9,958 \\
11,669 \\
13,141 \\
27,436 \\
62,204 \\
\end{array}$ \\
\hline $\begin{array}{l}0-100 \\
101-200 \\
201-400 \\
100+ \\
\text { Total } \\
\end{array}$ & 7 & $\begin{array}{r}24 \\
0 \\
0 \\
0 \\
24 \\
\end{array}$ & $\begin{array}{r}335 \\
0 \\
0 \\
0 \\
385 \\
\end{array}$ & $\begin{array}{r}131 \\
10 \\
1 \\
1 \\
143 \\
\end{array}$ & $\begin{array}{r}2,809 \\
1,339 \\
390 \\
403 \\
4,941 \\
\end{array}$ & $\begin{array}{r}155 \\
10 \\
1 \\
1 \\
167 \\
\end{array}$ & $\begin{array}{r}3,194 \\
1,339 \\
390 \\
403 \\
5,326 \\
\end{array}$ \\
\hline $\begin{array}{l}0-100 \\
101=200 \\
201-400 \\
400+ \\
\text { Total }\end{array}$ & 8 & $\begin{array}{l}8 \\
0 \\
0 \\
0 \\
8 \\
\end{array}$ & $\begin{array}{r}302 \\
0 \\
0 \\
0 \\
302 \\
\end{array}$ & $\begin{array}{r}26 \\
0 \\
0 \\
0 \\
26 \\
\end{array}$ & $\begin{array}{r}301 \\
0 \\
0 \\
0 \\
301 \\
\end{array}$ & $\begin{array}{r}34 \\
0 \\
0 \\
0 \\
34 \\
\end{array}$ & $\begin{array}{r}603 \\
0 \\
0 \\
0 \\
603 \\
\end{array}$ \\
\hline $\begin{array}{r}0-100 \\
101-200 \\
201-400 \\
401+ \\
\text { Total } \\
\end{array}$ & 9 & $\begin{array}{r}101 \\
49 \\
28 \\
9 \\
187 \\
\end{array}$ & $\begin{array}{r}4,664 \\
6,507 \\
7,965 \\
5,911 \\
25,047 \\
\end{array}$ & $\begin{array}{r}6 \\
3 \\
0 \\
1 \\
10 \\
\end{array}$ & $\begin{array}{r}405 \\
330 \\
0 \\
497 \\
1,232 \\
\end{array}$ & $\begin{array}{r}107 \\
52 \\
28 \\
10 \\
197 \\
\end{array}$ & $\begin{array}{r}5,069 \\
6,837 \\
7,965 \\
6,408 \\
26,279 \\
\end{array}$ \\
\hline $\begin{array}{l}0-100 \\
101-200 \\
20 !-400 \\
400+ \\
\text { Total }\end{array}$ & iõ & $\begin{array}{r}13 \\
0 \\
0 \\
0 \\
13 \\
\end{array}$ & $\begin{array}{r}223 \\
0 \\
0 \\
0 \\
223 \\
\end{array}$ & $\begin{array}{l}8 \\
0 \\
0 \\
0 \\
8\end{array}$ & $\begin{array}{r}51 \\
0 \\
0 \\
0 \\
51\end{array}$ & $\begin{array}{r}21 \\
0 \\
0 \\
0 \\
21\end{array}$ & $\begin{array}{r}274 \\
0 \\
0 \\
0 \\
274\end{array}$ \\
\hline $\begin{array}{l}\text { Grand Total } \\
0-100 \\
101-200 \\
20 i-400 \\
401+\end{array}$ & $\begin{array}{l}\text { All } 10 \\
\text { Regions }\end{array}$ & $\begin{array}{r}580 \\
139 \\
75 \\
69 \\
\end{array}$ & $\begin{array}{l}22,867 \\
19,909 \\
22,942 \\
40,367 \\
\end{array}$ & $\begin{array}{r}498 \\
93 \\
47 \\
45 \\
\end{array}$ & $\begin{array}{l}\cdot \\
11,239 \\
13,129 \\
13,770 \\
25,095 \\
\end{array}$ & $\begin{array}{r}1,078 \\
.232 \\
122 \\
114 \\
\end{array}$ & $\begin{array}{l}37,106 \\
33,038 \\
36,712 \\
65,462 \\
\end{array}$ \\
\hline \multicolumn{2}{|c|}{ Combined Totals } & 863 & 106,085 & 683 & 66,233 & 1,546 & $172,31.8$ \\
\hline
\end{tabular}

Note: Insludes all plant sizos.

Source: DOE Powerplant Listing, July 1978 


$$
\begin{gathered}
\text { EXHIBIT A-2l } \\
\text { Projected New Oil and Gas steam Plants } \\
\text { By DOE Region } \\
1978-1987
\end{gathered}
$$

\begin{tabular}{|l|r|r||r|r||r|r|}
\hline \multirow{2}{*}{ Region } & \multicolumn{2}{|c||}{ 0il } & \multicolumn{2}{c||}{ Gas } & \multicolumn{2}{c|}{ Total } \\
\cline { 2 - 7 } & No. & \multicolumn{1}{|c||}{ MW } & No. & MW & No. & \multicolumn{1}{c|}{ MW } \\
\hline 1 - New Eng. & 1 & 600 & - & - & 1 & 600 \\
3- Mid-At1. & 3 & 1,820 & - & - & 3 & 1,820 \\
4-S. Atl. & 5 & 2,645 & - & - & 5 & 2,645 \\
5 - Midwest & 1 & 60 & - & - & 1 & 60 \\
6 - S. West & 1 & 507 & 5 & 706 & 6 & 1,213 \\
8 - N. Central & 1 & 30 & - & - & 1 & 30 \\
9 - West & 6 & 654 & - & - & 6 & 654 \\
\hline Total & 18 & 6,316 & 5 & 706 & 23 & 7,022 \\
\hline
\end{tabular}

Note: (1) Includes all plant sizes.

(2) Inventory does not list any projected oil and gas steam plants in DOE Regions $2(\mathrm{NY} / \mathrm{NJ}), 7$ (Central), and 10 ( $\mathrm{N}$. West).

Source: DOE Powerplant Inventory, December 1977 
EXHIBIT A-22

Project New $\mathrm{O} i \mathrm{l}$ and Gas Steam Plants by Region and Utility Company

\begin{tabular}{|c|c|c|c|c|c|}
\hline Company Name & Region & Unit ID \& No. & $\begin{array}{l}\text { Tuel } \\
\text { Type }\end{array}$ & $\underset{M N}{\text { Sizc }}$ & $\begin{array}{l}\text { Projected } \\
\text { Date }\end{array}$ \\
\hline $\begin{array}{l}\text { Central Maine } \\
\text { Puwer Co. }\end{array}$ & 1 & W.F. Wyman No. 4 & $0 i 1$ & 600 & $12-78$ \\
\hline $\begin{array}{l}\text { Baltimore Gas \& } \\
\text { Electric }\end{array}$ & 3 & Brandon Shores No. 1 & $0 i 1$ & 610 & $3-81$ \\
\hline $\begin{array}{l}\text { Baltimore Gas \& } \\
\text { Electric }\end{array}$ & & Brandon Shores No. 2 & $0 i 1$ & 610 & $1-83$ \\
\hline $\begin{array}{l}\text { Potomac Electric } \\
\text { Power }\end{array}$ & & Chalk Point No. 4 & FDG & 600 & $12-81$ \\
\hline Florida Power Corp. & 4 & Anclote No. 2 & F06 & 556 & $4-78$ \\
\hline Florida Power Corp. & & Unknown No. 2 & F06 & 200 & $10-80$ \\
\hline $\begin{array}{l}\text { Florlda Power \& } \\
\text { Light }\end{array}$ & & Martin County No. 1 & F06 & 863 & 1980 \\
\hline $\begin{array}{l}\text { Florida Puwer \& } \\
\text { Light }\end{array}$ & & Martin County No. 2 & F06 & 863 & 1981 \\
\hline $\begin{array}{l}\text { Savannah Electric \& } \\
\text { Power Co. }\end{array}$ & & Effingham No. 1 & $0 i 1$ & 163 & $3-79$ \\
\hline City of Detroit & 5 & Mistersky & F06 & 60 & $6-78$ \\
\hline $\begin{array}{l}\text { Monroe Utilities } \\
\text { Commission }\end{array}$ & 6 & Monroe No. 14 & NG & 100 & 1979 \\
\hline City of Punca, OK & & Ponca stm. No. 2 & NG 1 & 13 & $1-78$ \\
\hline $\begin{array}{l}\text { Austin Electric } \\
\text { Dept. }\end{array}$ & & Decker No. 2 & Gas & 400 & $1-78$ \\
\hline City of Bryan . & & Roland Dansby No. 1 & Gas & 105 & $2-78$ \\
\hline $\begin{array}{l}\text { Gulf States } \\
\text { Utilities }\end{array}$ & & Sabine No. 5 & $0 i 1$ & 507 & $9-79$ \\
\hline City of Lubbock & & Holly Ave. No. 2 & Gas & 58 & $6-78$ \\
\hline $\begin{array}{c}\text { Montana-Dakota } \\
\text { Utilities }\end{array}$ & 8 & Glendive No. 1 & $0 i 1$ & 30 & $5-79$ \\
\hline $\begin{array}{l}\text { San Diego Gas \& } \\
\text { Electric Co. }\end{array}$ & 9 & Encina No. 5 & $0 i 1$ & 298 & $10-78$ \\
\hline $\begin{array}{l}\text { Citizens Utili- } \\
\text { ties, Hawaii }\end{array}$ & & Port Al len, S2 & $0 i 1$ & 10 & $6-83$ \\
\hline $\begin{array}{l}\text { litizen Uitili- } \\
\text { ties, Hawaii }\end{array}$ & & Port Âllen, S3 & 0il & 25 & 7-ôō \\
\hline $\begin{array}{l}\text { Hawaiian Electric } \\
\text { Company }\end{array}$ & & Kahe, 6 & $0 i 1$ & 135 & $7-80$ \\
\hline $\begin{array}{l}\text { Hawaiian Electric } \\
\text { Company }\end{array}$ & & Kahe, 7 & $0 \mathrm{il}$ & 163 & $12-86$ \\
\hline $\begin{array}{l}\text { Hawaiian Electric } \\
\text { Company }\end{array}$ & & W.H. Hill No, 7 & $0 i 1$ & 23 & $10-82$ \\
\hline
\end{tabular}


1

INDUSTRIAL FUEL CONSUMPTION FORECASTS 
EXHIBIT A-23

Summary of Fuel Consumption by Industrial sectcr

\begin{tabular}{|l|r|r|r|c|}
\hline \multirow{2}{*}{ Primary Fuel } & \multicolumn{3}{|c|}{ Trillions of Btu's } & Annual Growth Rates \\
\cline { 2 - 5 } & 1975 & 1985 & 1990 & $1975-1990$ \\
\hline Electricity & 2,179 & 4,181 & 5,195 & 6.0 \\
Distillate 0i1 & 476 & 1,527 & 2,005 & 10.1 \\
Residual 0i1 & 793 & 1,679 & 2,143 & 6.9 \\
Liquid Gas & 314 & 1,084 & 1,453 & 10.8 \\
Coal & 1,391 & 2,429 & 3,006 & 5.3 \\
Met Coal & 2,294 & 2,587 & 2,724 & 1.2 \\
Naptha & 281 & 452 & 592 & 5.1 \\
Natural Gas & 7,937 & 8,193 & 9,163 & 1.0 \\
\hline Total & 15,665 & 22,135 & 26,281 & 3.5 \\
\hline
\end{tabular}

Source: 1975,1985 , and 1990 data were obtained from The Annua: Report To Congress, 1977, supplied by The Energy Information Administration, $\overline{\mathrm{DOE}}$ 
EXHIBIT A-24

Summary of Fuel Consumption

By Industrial Section

1975-1990

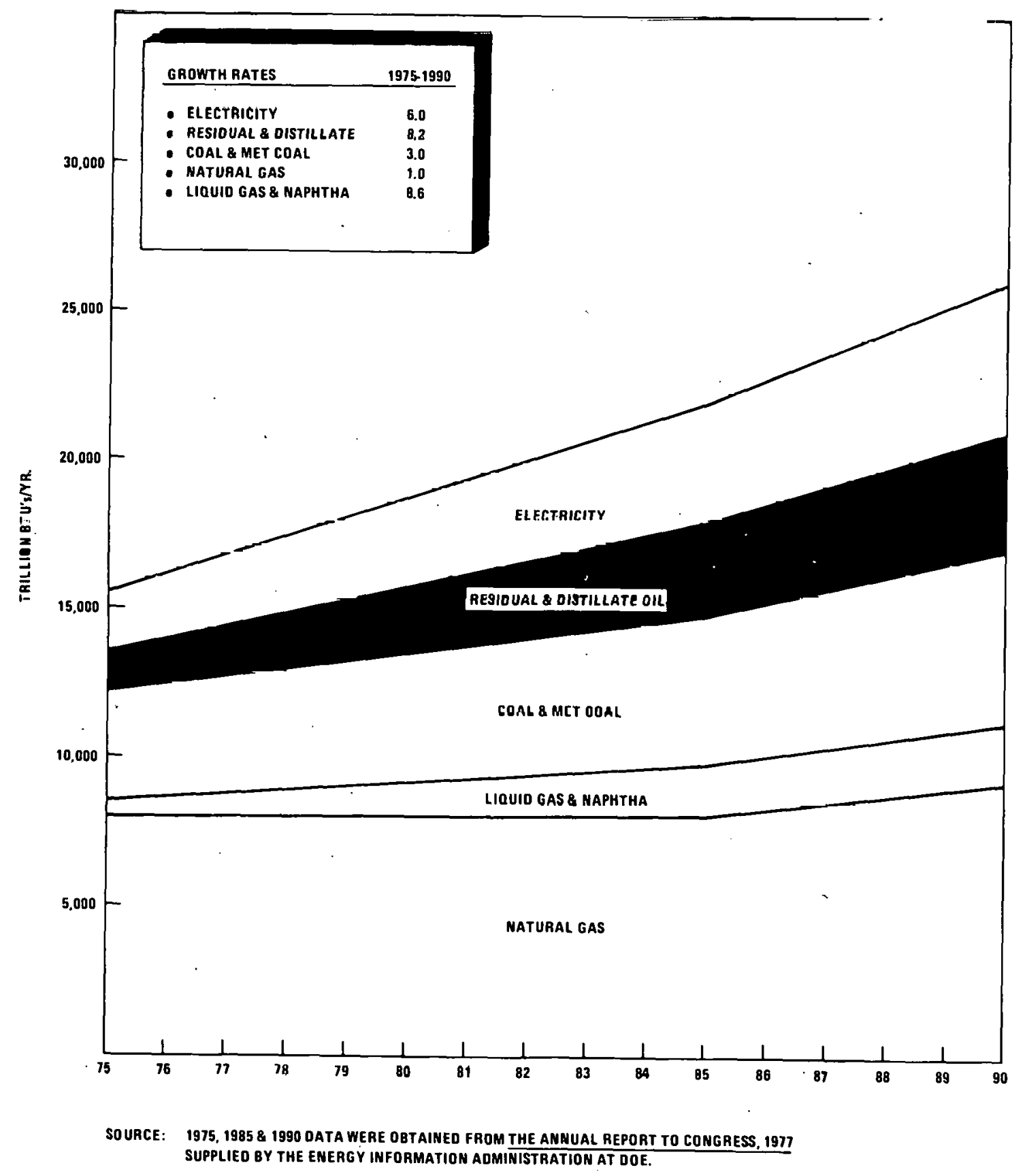


EXHJBIT A-25

Summary of Regional Data of Fuel Consumption in the Industrial sector 1975

\begin{tabular}{|l|r|r|r|r|r|r|r|r|r|r|r||r|}
\hline \multirow{2}{*}{ Primary Fuel } & \multicolumn{8}{|c|}{ Regional Industrial Consumption in Trillions of Btu/Yr } \\
\cline { 2 - 11 } & New Eng. & NY/Nu & Mid Atl. & \multicolumn{1}{|c|}{. Atl. } & Midwest & S. West & Central & N. Cen亡ral & West & N. West & Total \\
\hline Electricity & 64 & 142 & 244 & 515 & 519 & 253 & 85 & 44 & 165 & 148 & 2,179 \\
Distillate 0i1 & 15 & 29 & 57 & 74 & 95 & 70 & 21 & 35 & 46 & 36 & 476 \\
Residuall 0j1 & 109 & 72 & 124 & 151 & 101 & 109 & 6 & 37 & 46 & 37 & 793 \\
Liquid Gas - & 15 & 10 & 22 & 45 & 64 & 84 & 37 & 10 & 28 & 1 & 314 \\
Coal & 5 & 66 & 333 & 211 & 579 & 37 & 76 & 50 & 9 & 26 & 1,391 \\
Met Coal & - & 94 & 833 & 221 & 979 & 26 & 7 & 83 & 50 & - & 2,294 \\
Naptha & 12 & 30 & 9 & 6 & 68 & 143 & 1 & - & 11 & - & 281 \\
Natural Gas & 57 & 168 & 424 & 843 & 1,547 & 3,318 & 439 & 242 & 682 & 216 & 7,937 \\
\hline Total & 276 & 612 & 2,046 & 2,066 & 3,950 & 4,041 & 672 & 500 & 1,035 & 464 & 15,665 \\
\hline
\end{tabular}

Source: 1975 data were obtained from the Annual Report to Congress, 1977, supplied by The Energy Administration, DOE 


\section{EXHIBIT A-26}

Summary of Regional Data of Fuel Consumption in the Industrial sector 1985

\begin{tabular}{|c|c|c|c|c|c|c|c|c|c|c|c|}
\hline \multirow{2}{*}{ Primary Fuel } & \multicolumn{11}{|c|}{ Regiona: Industrial Consumption in rillions of Btu/Yr } \\
\hline & New Eng. & $\mathrm{NY} / \mathrm{NJ}$ & Mid-At1. & S. Atl. & Midwest & S. West & Central & N. Central & West & N. West & Total \\
\hline Eiectricity & 105 & 247 & 457 & 1,032 & 969 & 559 & 189 & 109 & 239 & 276 & 4,181 \\
\hline Distillate 0 il & 26 & 68 & 2.13 & 165 & 461 & 179 & 68 & 116 & 94 & 139 & 1,527 \\
\hline Residual 0il & 205 & 110 & 155 & 224 & 222 & 545 & 25 & 34 & 76 & 85 & 1,679 \\
\hline L-quid Gas & 49 & 34 & 56 & 108 & 382 & 206 & 119 & 41 & 80 & 10 & 1,084 \\
\hline Coal & 3 & 70 & 312 & 307 & 1,178 & 95 & 123 & 212 & 45 & 83 & 2,429 \\
\hline Met Coal & - & 157 & 1,0109 & 242 & 998 & 21 & .9 & 92 & 60 & - & 2,587 \\
\hline Naptha & 18 & 50 & 14 & 10 & 101 & 242 & 2 & - & 16 & - & 452 \\
\hline Natural Gas & 80 & 214 & 413 & 808 & 521 & 4,831 & 254 & 166 & 833 & 63 & 8,193 \\
\hline Total & 484 & 950 & $2,6 \geq 8$ & 2,894 & 4,832 & 6,678 & 798 & 769 & 1,443 & 657 & 22,135 \\
\hline
\end{tabular}

Source: 1985 data were obtained from the Annual Report to Congress, 1977, supplied by The Energy Administration, D0E 
EXHIBIT A-27

Summary of Regional Data of Fuel Consumption in the Industrial Sector 1990

\begin{tabular}{|l|r|r|r|r|r|r|r|r|r|r|r||r|}
\hline \multirow{2}{*}{ Primary Fuel } & \multicolumn{8}{|c|}{ Regional Industrial Consumption in Trillions of BTU/Yr } \\
\cline { 2 - 12 } & New Eng. & NY/NJ & Mid-Atl. & S. Atl. & Midwest & S. West & Central & N. Central & West & N. West & Total \\
\hline Electricity & 124 & 300 & 574 & 1,331 & 1,221 & 695 & 241 & 127 & 278 & 303 & 5,195 \\
Distillate 0il & 30 & 80 & 257 & 235 & 546 & 238 & 117 & 186 & 110 & 205 & 2,005 \\
Residual 0il & 242 & 123 & 174 & 306 & 238 & 779 & 41 & 43 & 85 & 111 & 2,143 \\
Liquid Gas & 62 & 42 & 69 & 156 & 455 & 277 & 207 & 67 & 98 & 21 & 1,453 \\
Coal & 3 & 80 & 356 & 426 & 1,308 & 129 & 203 & 332 & 56 & 114 & 3,006 \\
Met Coal & - & 165 & 1,057 & 257 & 1,052 & 22 & 10 & 97 & 64 & - & 2,724 \\
Naptha & 23 & 64 & 18 & 13 & 127 & 324 & 2 & - & 21 & - & 592 \\
Natural Gas & 89 & 236 & 445 & 752 & 568 & 5,893 & 139 & 61 & 981 & - & 9,163 \\
\hline Total & 572 & 1,089 & 2,951 & 3,474 & 5,516 & 8,358 & 961 & 914 & 1,693 & 754 & 25,281 \\
\hline
\end{tabular}

Source: 1990 data were obtained from the Annual Report to Congress, 1977, supplied by The Energy Information Administration, DOE. 
EXHIBIT A-28

Summary of Forecasted.Industrial

Fuel Consumption to Region 1

New England

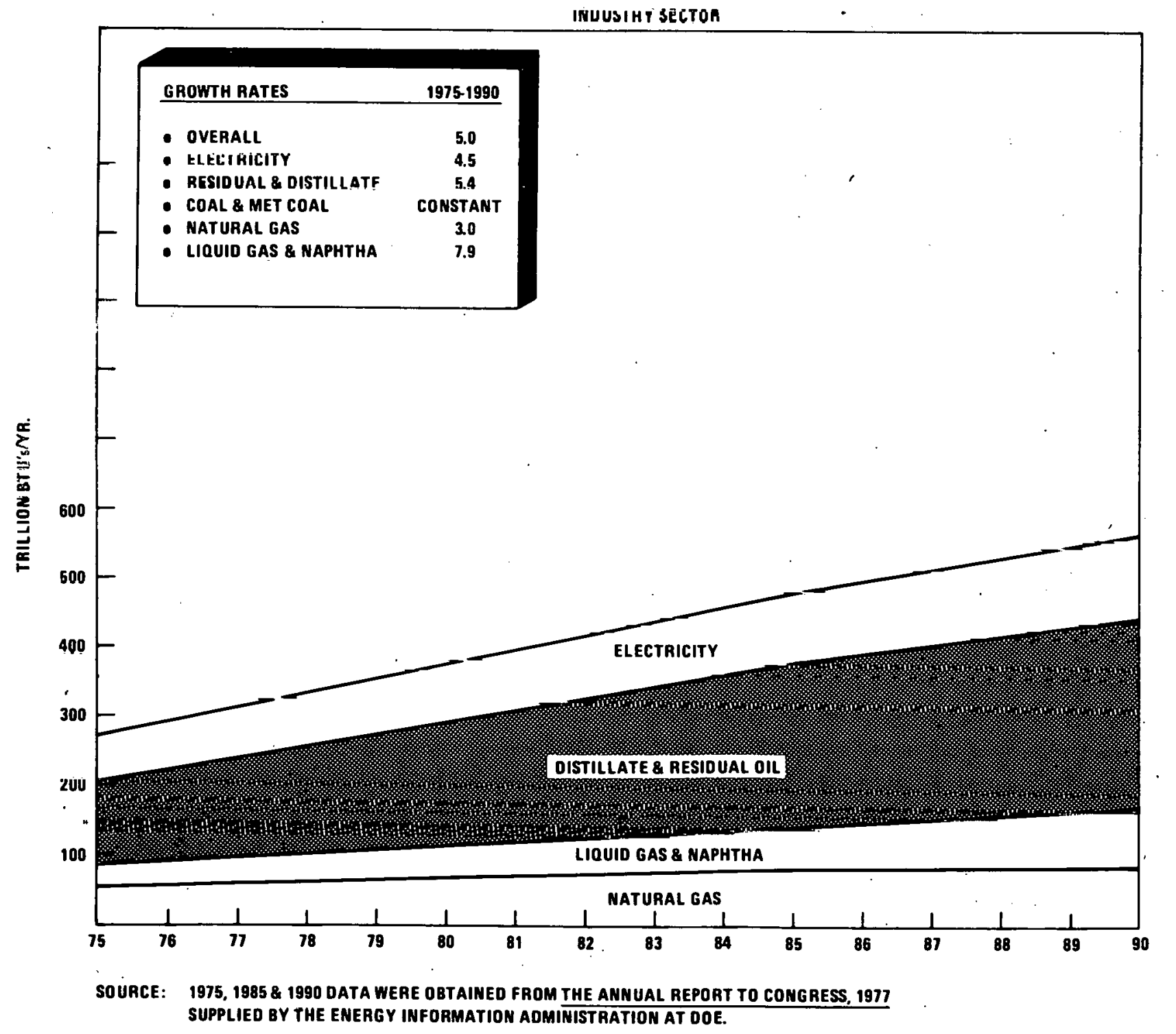


EXHIBIT A-29

Surnmary of Forecasted Industrial

Fuel Consumption to Region 2

New York/New Jersey

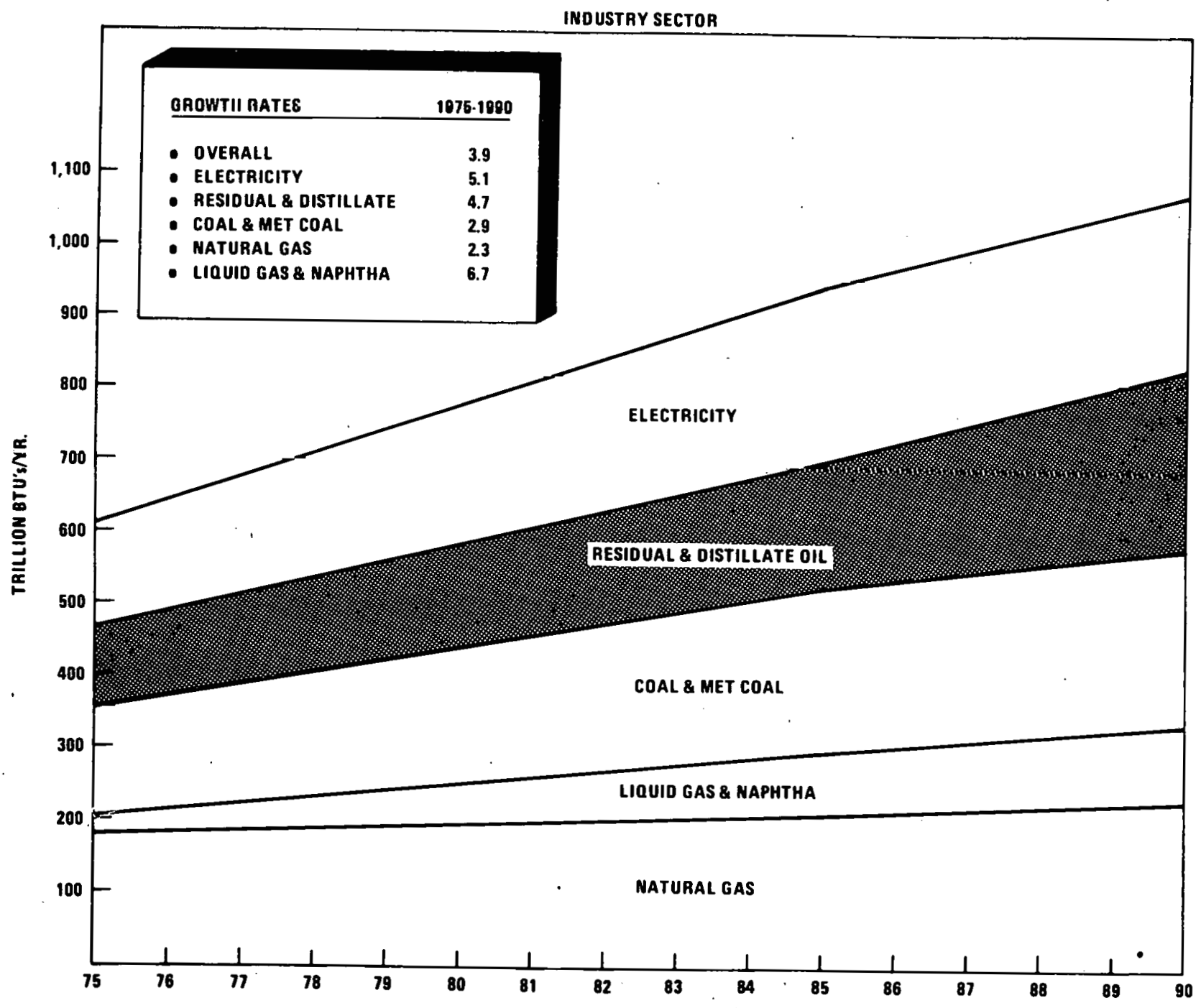

SOURCE: 1975, 1985 \& 1990 DATA WERE OBTAINED FROM THE ANNUAL REPORT TO CONGRESS, 1977 SUPPLIED BY THE ENERGY INFORMATION ADMINISTRATION AT DOE. 
EXHIBIT A-30

Summary of Forecasted Industrial

Fuel Consumption to Region 3

Mid-Atlantir.

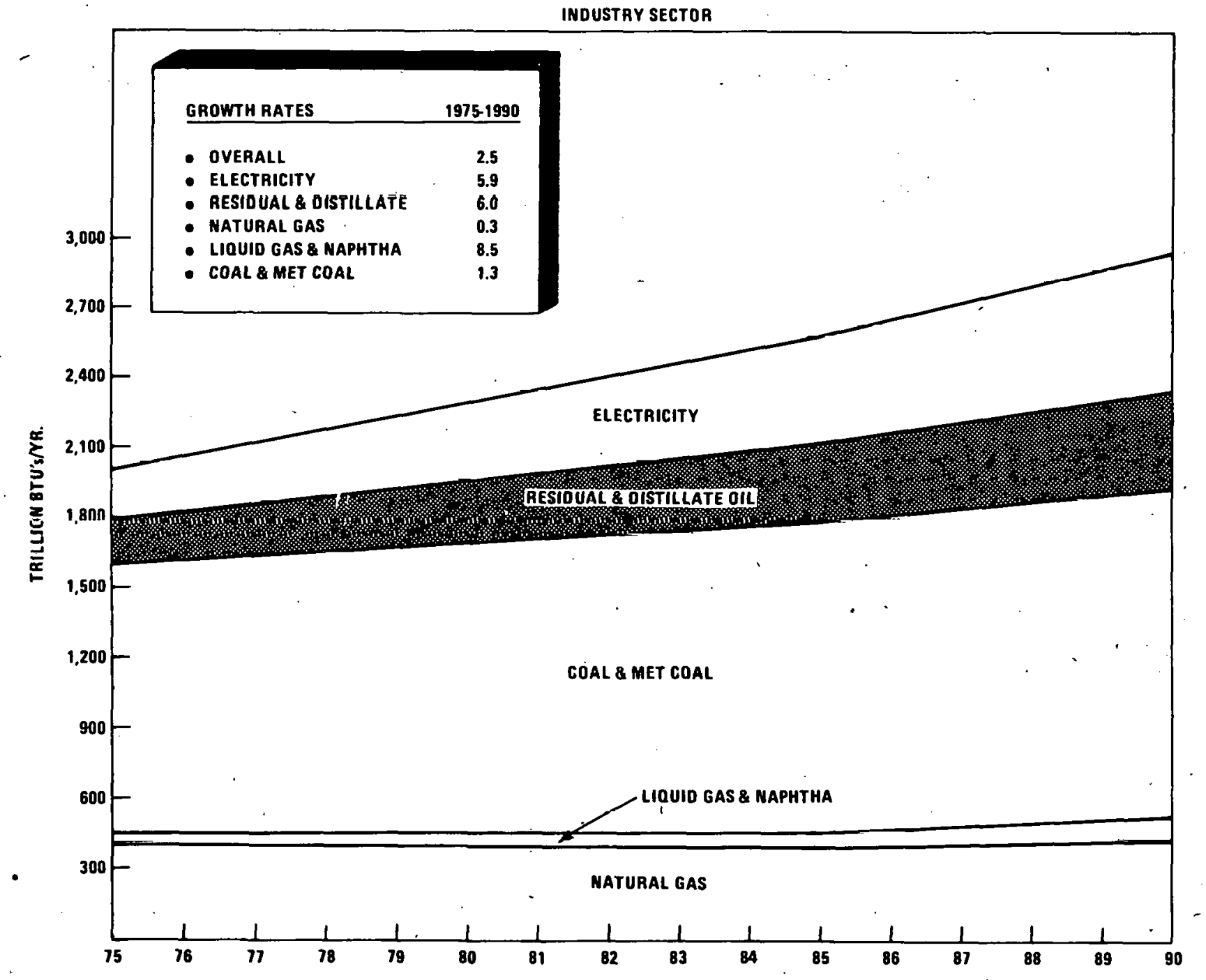

SOURCE: 1975, 1985 \& 1990 DATA WERE OBTAINED FROM THE ANNUAL REPORT TO CONGRESS, 1977 SUPPLIED BY THE ENERGY INF.ORMATION ADMINISTRATION AT DOE. 
EXHIBIT A-3I

Summary of Forecasted Industrial

Fuel Consumption to Region 4

South Atlantic

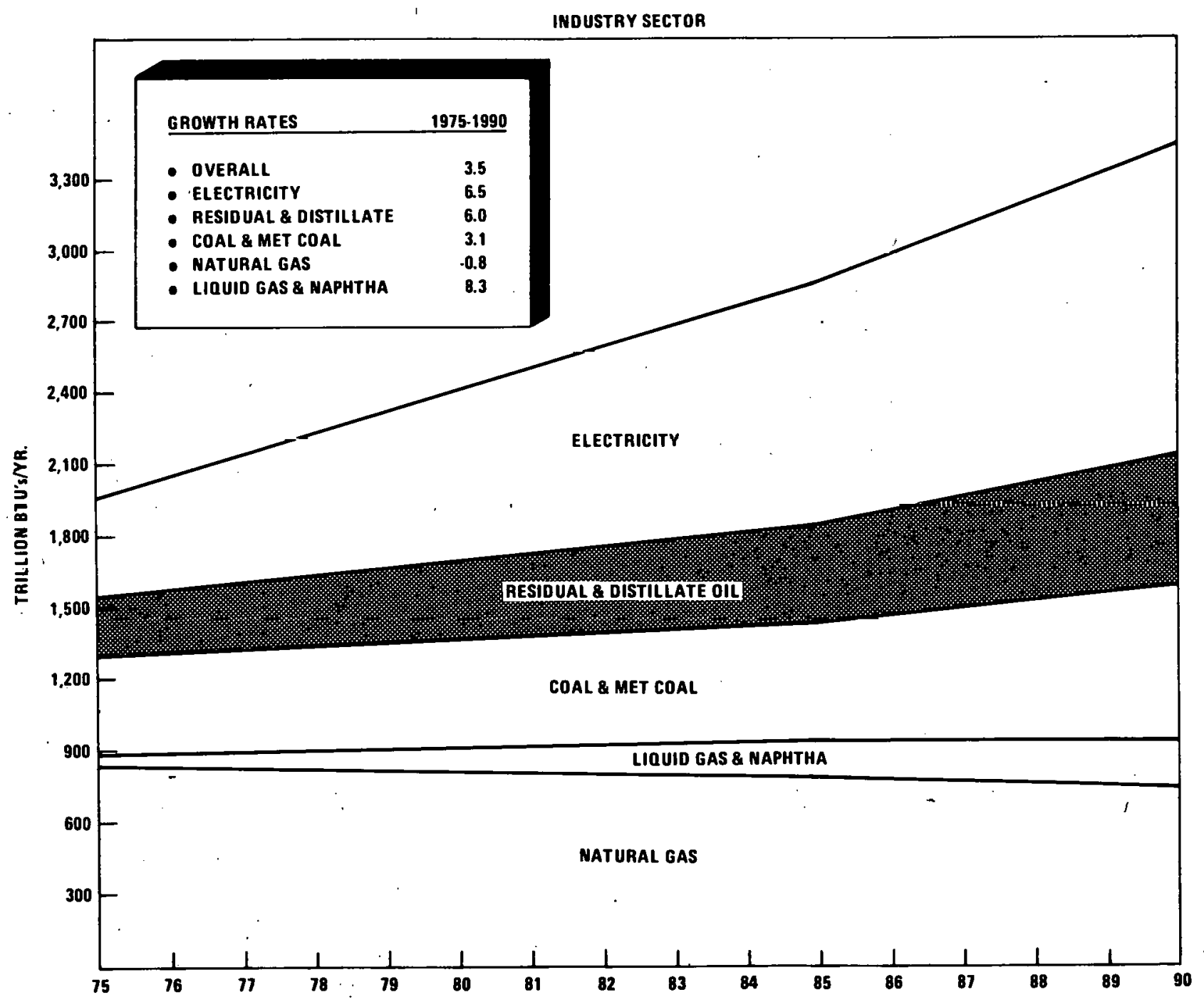

SOURCE: 1975, 1985 \& 1990 DATA WERE OBTAINED FROM THE ANNUAL REPORT TO CONGRESS, 1977 SUPPLIED BY THE ENERGY INFORMATION ADMINISTRATION AT DOE. 
EXHIBIT A-32

Summary of Forecasted Industrial

Fuel Consumption to Region 5

Midwest

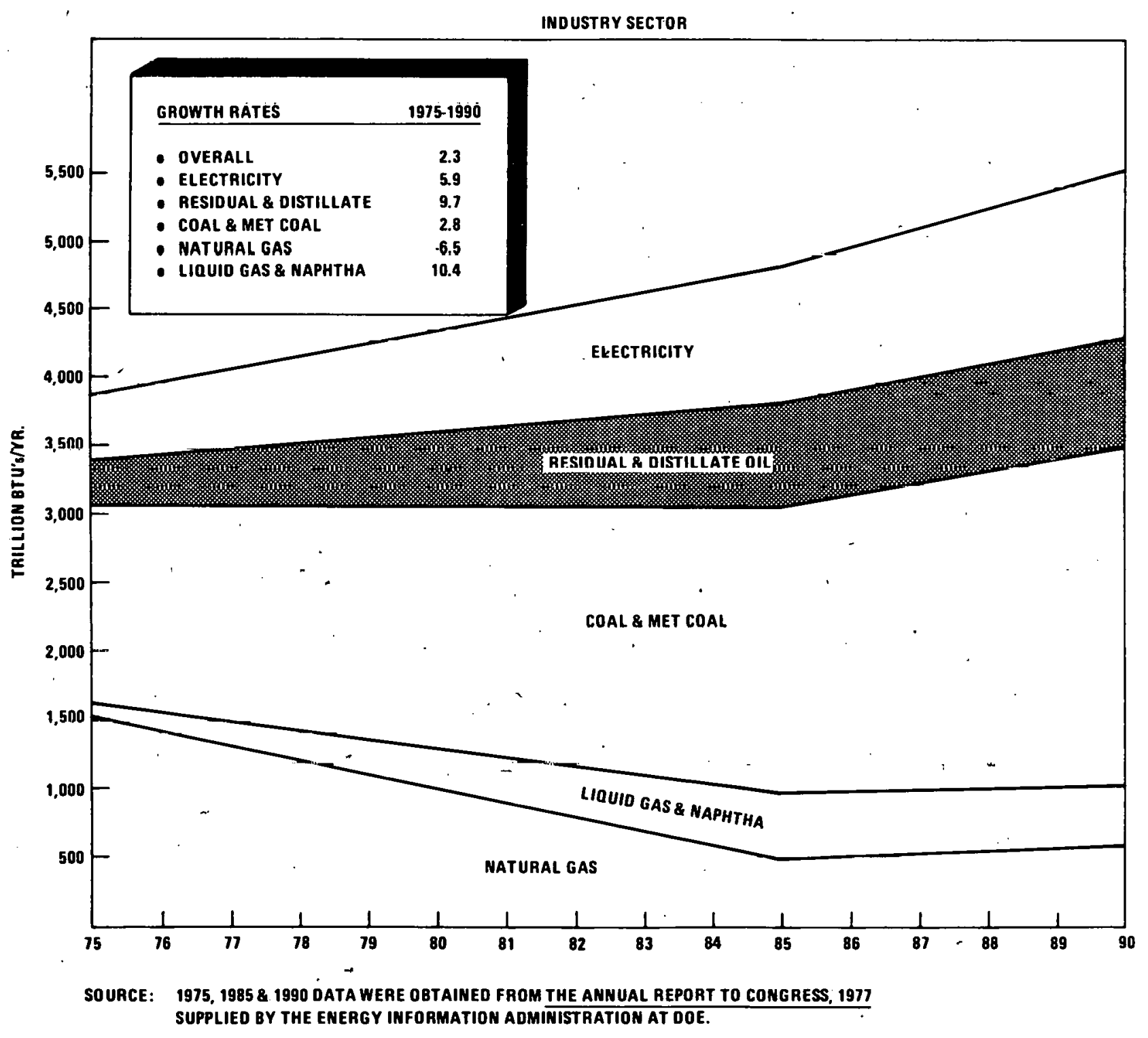


EXHIBIT A-33

Summary of Forecasted Industrial

Fuel Consumption to Region 6

Southwest

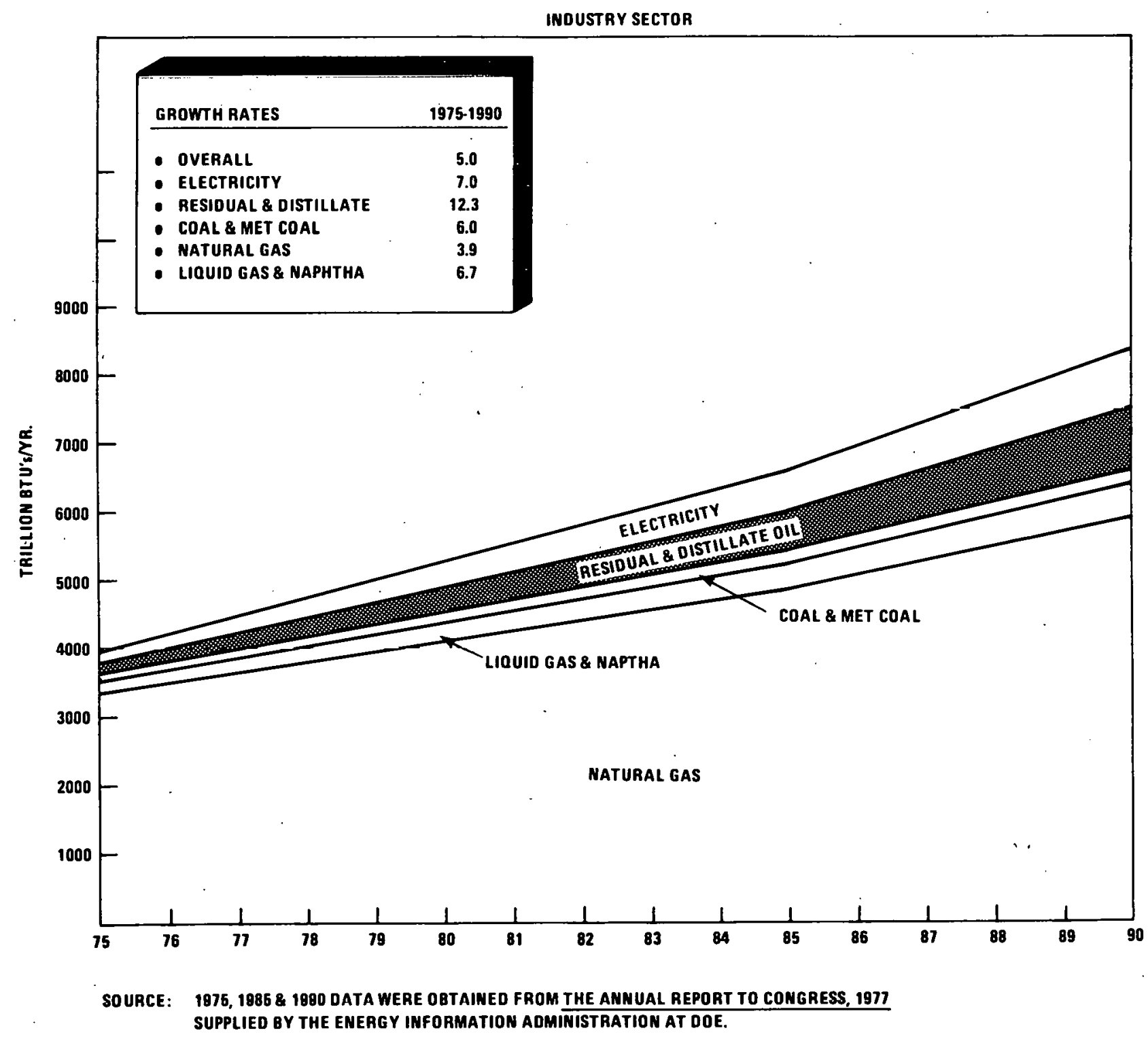


EXHIBIT A-34

Summary of Forecasted Industrial

Fuel Consumption to Region 7

Central

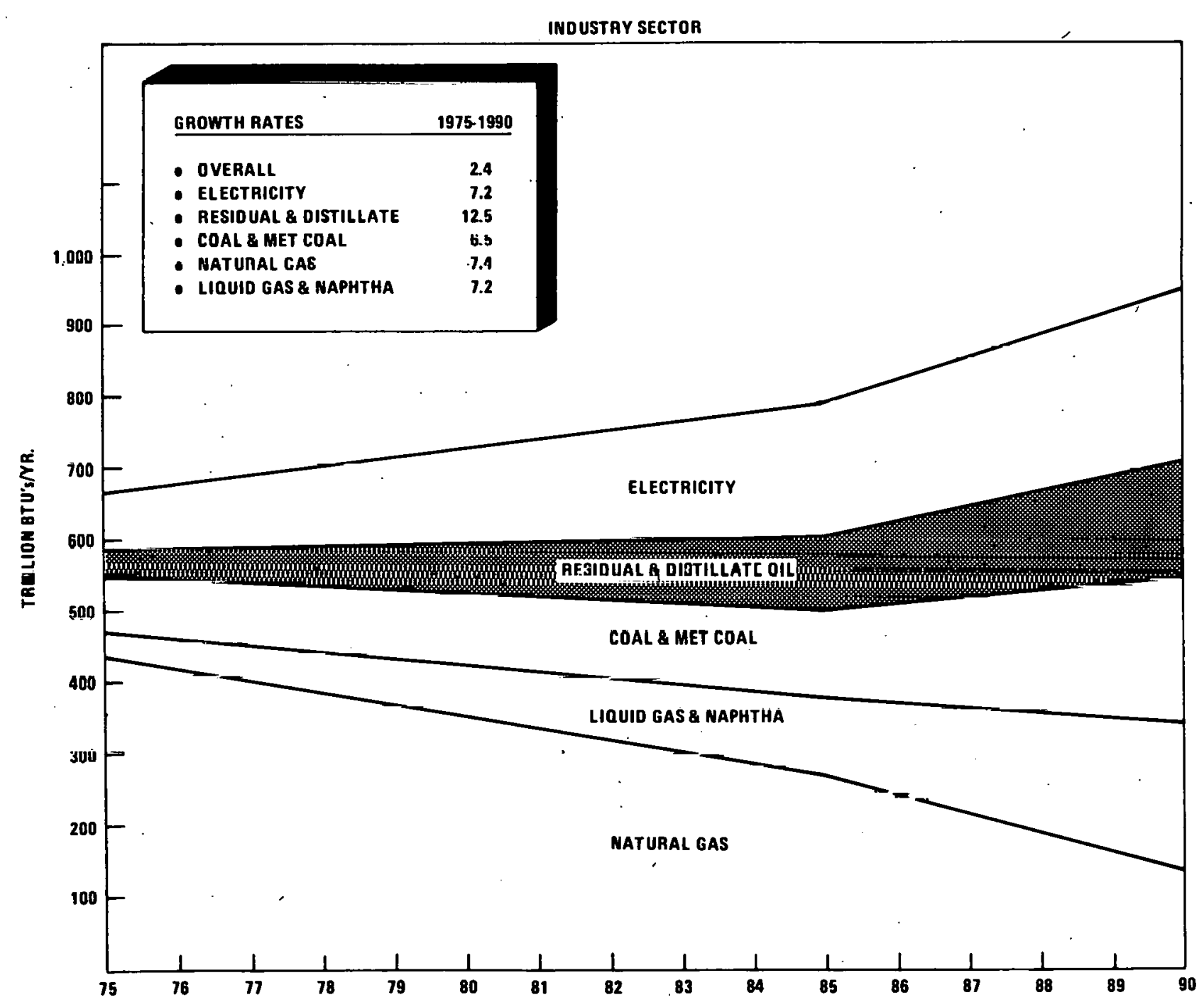

SOURCE: 1975, 198581990 DATA WERE OBTAINED FROM THE ANNUAL REPORT TO CONGRESS, 1977 .SUPPLIED BY THE ENERGY INFORMATION ADMINISTRATION AT DOE. 
EXHIBIT A-35

Summary of. Forecasted Industrial

Fuel Consumption to Region 8

North Central

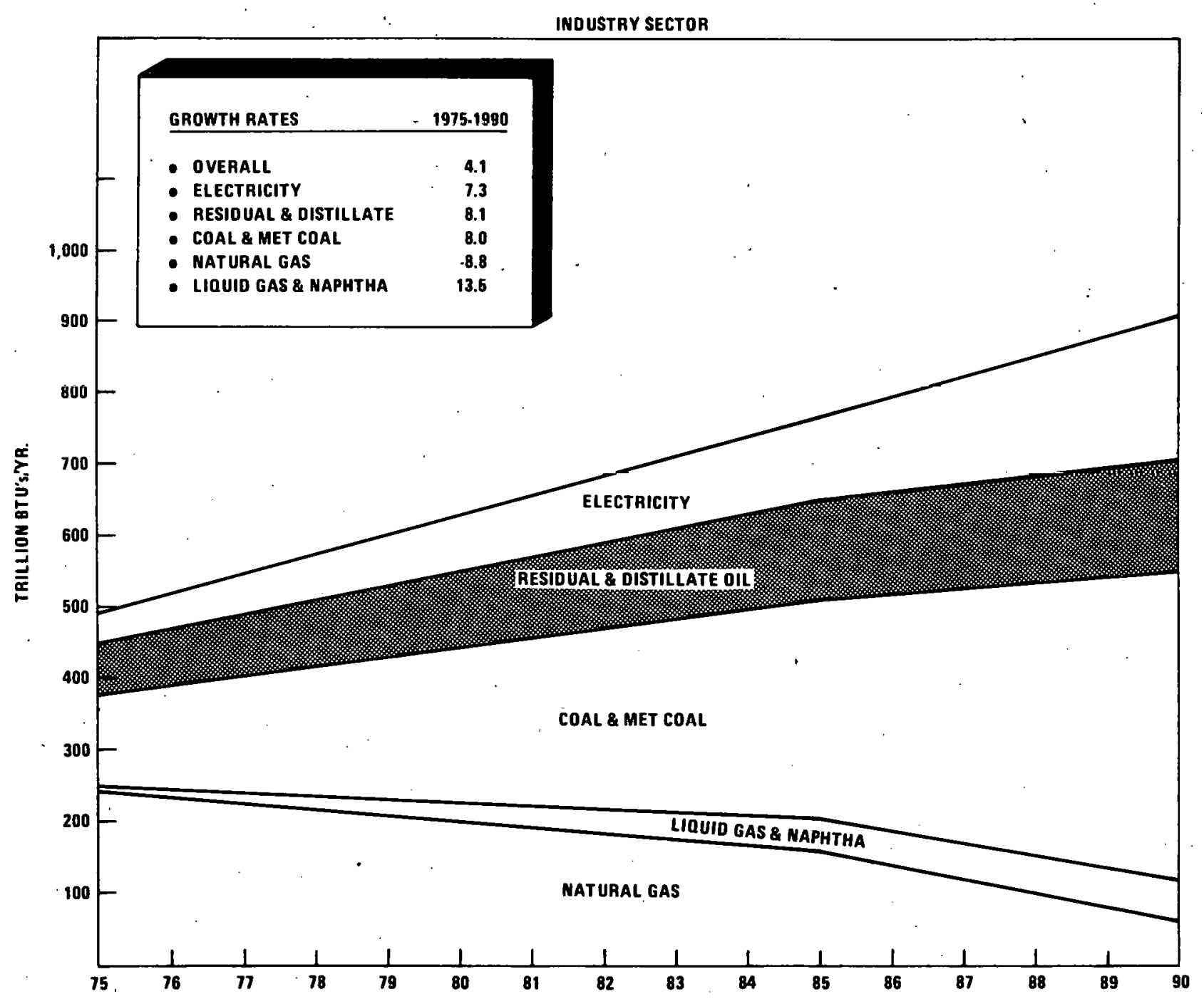

SOURCE: 1975, 1985 \& 1990 DATA WERE OBTAINED FROM THE ANNUAL REPORT TO CONGRESS, 1977 SUPPLIED BY THE ENERGY INFORMATION ADMINISTRATION AT DOE. 
EXHIBIT A-36

Summary of Forecasted Industrial

Fuel Consumption to Region 9

West

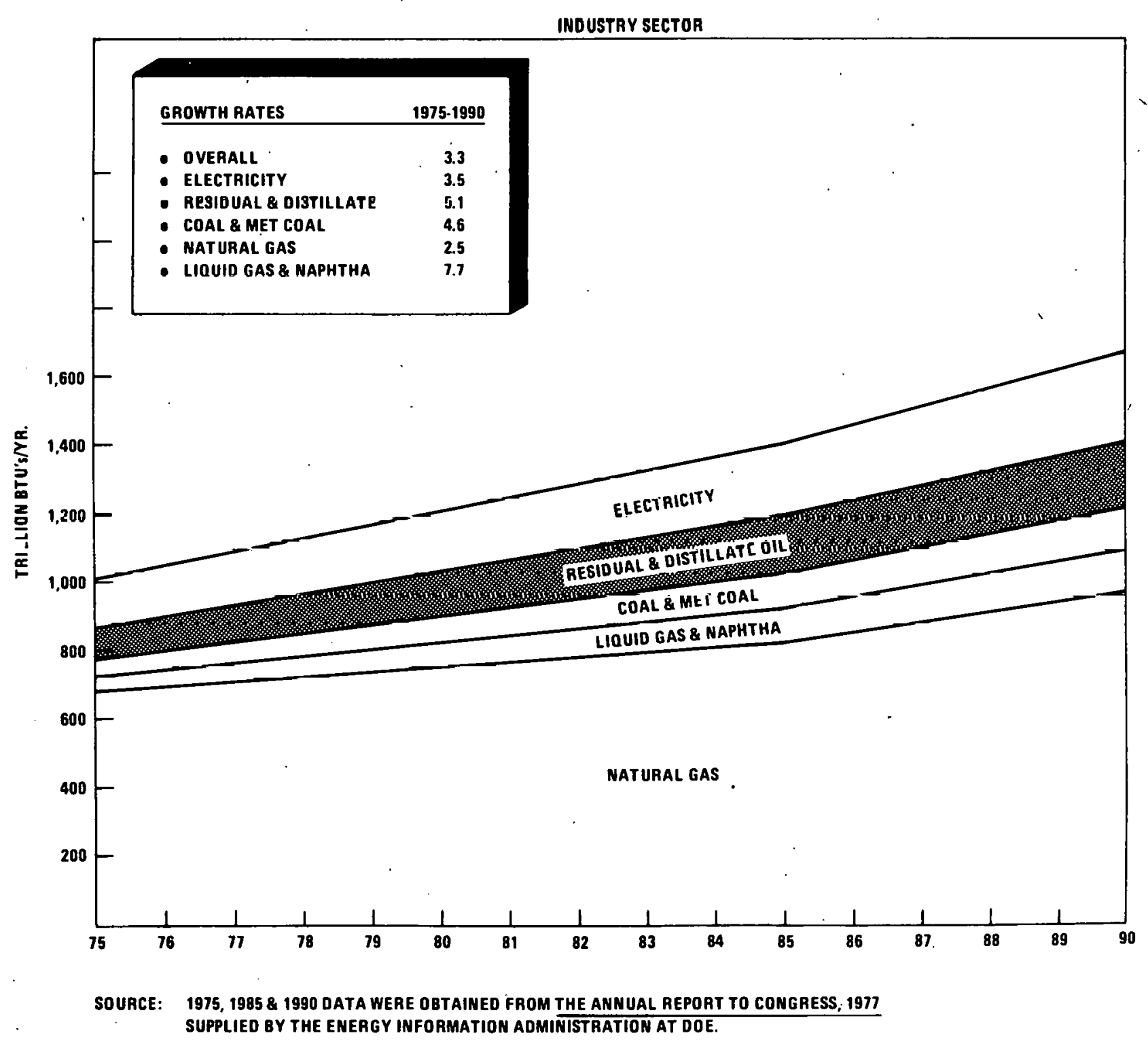




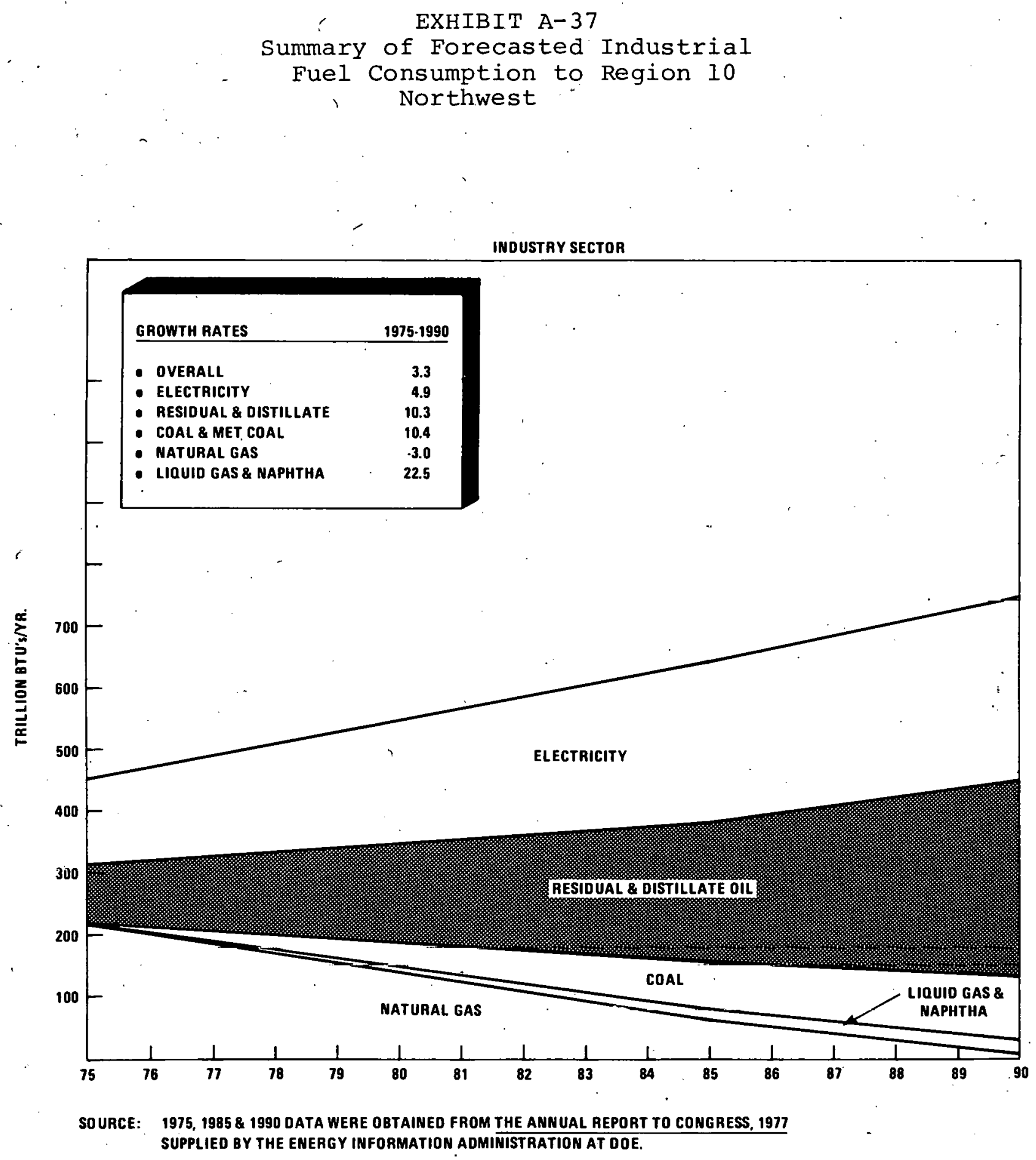




\begin{abstract}
APPENDIX B
THE POTENTIAL ENVIRONMENTAL HAZARDS OF BOILER FUELS PRODUCED FROM COAL LIQUEHFC'I'LUN PROCESSES
\end{abstract}




\section{APPENDIX B}

THE POTENTIAL ENVIRONMENTAL HAZARDS OF BOILER FUELS PRODUCED FROM COAL LIQUEFACTION PROCESSES

This appendix presents an assessment of the potential environmental hazards of boiler fuels produced from coal liquefaction processes. The study thrust is an assessment of the products as they will leave the coal liquefaction plant (not with the plant itself) and as they would be used in the boiler fuel market. This assessment is presented on a relative basis to the product it would most likely replace, No. 6 fuel oil.

The appendix is structured first, to present the various data available on the products. The three processes under review are at different stages of development and the available data were limited and not on a consistent basis. Therefore, independently, a methodology to assess the environmental hazards was developed by evaluating the basic chemical composition. The findings reached on the environmental hazards represent a combination of: currently available data; interviews with government, industry and union representatives; and judgments reached by the study team in evaluating the chemical composition.

1. THE ENVIRONMENTAL HAZARDS OF THE PRODUCTS OF DIRECT COAL LIQUEFACTION PROCESSES WERE ASSESSED IN RELATION TO NO. 6 FUEL OIL

(1) Three Direct Coal Liquefaction Processes Were Examined Using Illinois No. 6 Coal As The Feedstock

- The Department of Energy (DOE) is sponsoring the development of several direct coal liquefaction processes as part of a national effort to gain energy independence.

- Our study was targeted at analyzing the environmental hazards for three of these direct coal liquefaction processes:

$$
\begin{aligned}
& \text { - Solvent Refined Coal (SRC-II) * } \\
& \text { - } \quad \text { H-Coal } * * \\
& \text { Exxon Donor Solvent (EDS). *** }
\end{aligned}
$$

\footnotetext{
* Pittsburgh and Midway Coal Co. (PAMCO)

** Hydrocarbon Research, Inc. (HRI)

*** Exxon, Inc.
} 
- These processes are approaching the pilot demonstration limit or "minipilot" stage of development. The plants will produce a synthetic crude oil, parts of which are targeted for , use as boiler fuels by utilities.

Il'linois No. 6 coal was selected as the coal feedstock for evaluation in this study.

- The composition of the product of direct liquefaction processing will - depend to a great degree on the type of coal feedstock.

- Illinois No. 6 is a promising feedstock because of availability and compatability.

- Much of the development work to date has been performed using Illinois No. 6 coal in the feedstock.

- Analyses of ìllinois No. 6 coal are well documented, as shown in the Supplement to this Appendix.

(2) The Environmenta]. Hazards of Direct Liquefaction Products Were Compared To Those of No. 6 Fuel Oil

No. 6 fuel oil would be the primary competing product (No. 6 fuel oil is also commonly called Bunker $C$ or' PS-400 fuel oil).

- The handling procedures and environmental safeguards required in the boiler fuel market for No. 6 fuel oil are established. 
The assessment of environmental hazards of direct liquefaction products in this study is compared in relation to No. 6 fuel oil.

- The purpose of our assessment is to determine if safeguards above and beyond those already in place are required.

- No. 6 fuel oil is accepted in the marketplace at its current level of risk.

- A hazard assessment on - an absolute basis would raise questions that are presently being studied by NIOSH, , petroleum companies, and others on No. 6 fuel oil.

(3) The Composition of No. 6 Fuel oil Is Variable Because Specifications Are Based on Functional Rather than Compositional Requirements

No. 6 fuel oil represents a blend of distillation cuts at the refinery to satisfy customer specifications (with viscosity and sulfur content usually being by specifications). The actual. composition of No. 6 fuel oil will therefore depend on:

- Crude oil source

- Customer specifications

- Available distillation cuts

- Refinery processing

- Blend selected.

- The residual fuels are largely byproducts of operations aimed at maximizing the $y$ ield or quality of other petroleum products. As an example, Texaco mixes the heavy vacuum still residuum with off-specification cutter stock (distillate fuel oil) to produce No. 6 fuel 
oil, which meets the ASTM* standards for saybolt Furol viscosity and flash point.

Exhibit $\mathrm{B}-1$, on the following page, presents the three commonly used standards and specifications for No. 6 fuel oil.

\section{- ASTM standard \\ - Pacific standard \\ - Trade standard}

These standards are based on physical rather than compositional analyses.

In practice, there is no one composition of Number 6 fuel oil. Exhtbit B-2, following Exhibit B-1, presents typical metallic impurities that exist in different types of No. 6 fuel oil from two companies.

Exhibit B-3, following Exhibit B-2, presents chemical group compositional data for a No. 6 fuel oil. Although. this analysis can vary for the oil selected, the study team selected this analysis as a benchmark for No. 6 ruel oil. In practice, there would be a range of each of the chemical groups with the range constantly changing.

- The composition of No. 6 fuel oil can vary depending on the crude oils used, the refinery, and day of production.

- Oil companies have not performed detailed chemical analyses on residual fuel oil because of the great variation in product composition.

- Many analyses that have been done are considered proprietary information.

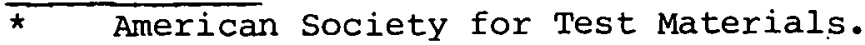


EXHIBIT $\mathrm{B}-1$

Department of Energy

THREE COMMONLY USED STANDARDS AND

SPECIFICATIONS FOR NUMBER 6 FUEL OIL

\section{Specification Unit of Measure \\ Flash point \\ OFahrenheit \\ Water and sediment Volume percent}

Viscosity

Saybolt Universal Sec a $100{ }^{\circ} \mathrm{F}$ Min

$\operatorname{Max}$

Saybolt Furol Sec a $122^{\circ} \mathrm{F}$ Min

Kinematic

Max

$\operatorname{Max}$

Gravity

OAPI

Specific gravity

1b./gal.

BTU/gal

Heat content
STANDARDS

\begin{tabular}{|c|c|c|}
\hline$\overline{\mathrm{ASTM}}$ & Pacific & Trade \\
\hline 140 & 150 & \\
\hline 2.00 & 2.00 & \\
\hline \multicolumn{3}{|l|}{$>900$} \\
\hline \multicolumn{3}{|l|}{9000} \\
\hline$>45$ & 60 & \\
\hline \multicolumn{3}{|l|}{300} \\
\hline$>92$ & & \\
\hline 638 & & \\
\hline
\end{tabular}

$14-16$

$7.998-8.108$

$150,700-152,000$ 
EXHIBIT B-2

Department of Energy

TYPICAL VARIATIONS IN METALLIC IMPURITIES

AND SULFUR CONTENT IN NUMBER 6 FUEL OILS

\section{Metallic}

Impurity

\section{sulfur}

" Vanadium

Nickel

Iron

Sodium

Calcium

\begin{tabular}{ll}
\multicolumn{2}{c}{ Company A } \\
\hline Low Sulfur & Regular Domestic \\
$\frac{\text { Fuel Oil }}{\text { (ppm) }}$ & $\frac{\text { Fuel oil }}{(\mathrm{ppm})}$
\end{tabular}

$5,000-10,000$

$29,000 *$

\begin{abstract}
$12-100$
\end{abstract}
$15-100$

$20-40$

25-50

$10-50$

\section{0}

15

10

4

2

\begin{tabular}{ll}
\multicolumn{2}{c}{ Company B } \\
\hline Low Sulfir & Regular Domestic \\
$\frac{\text { Fuel Oil }}{\text { (ppm) }}$ & $\frac{\text { Fuel Oil }}{\text { (ppm) }}$
\end{tabular}

$15,000-30,000$

$29,000 *$

$30-200$

350

$15-100$

25

5-50

115

15-75

5

15-75

5

* Expressed as 2.9 wt. \&

Source: Oak Ridge National Laboratory Report ORNL/TM-5529. Impact of Alternate Fuels on Industrial. Refractories and Refractory Insulation Applications, An Assessment, September 1976 


\section{EXHIBIT B-3}

Department of Energy

TYPICAL COMPOSITIONAL DATA FOR

BUNKER C FUEL

\section{CHEMICAL GROUP ANAIYSES}

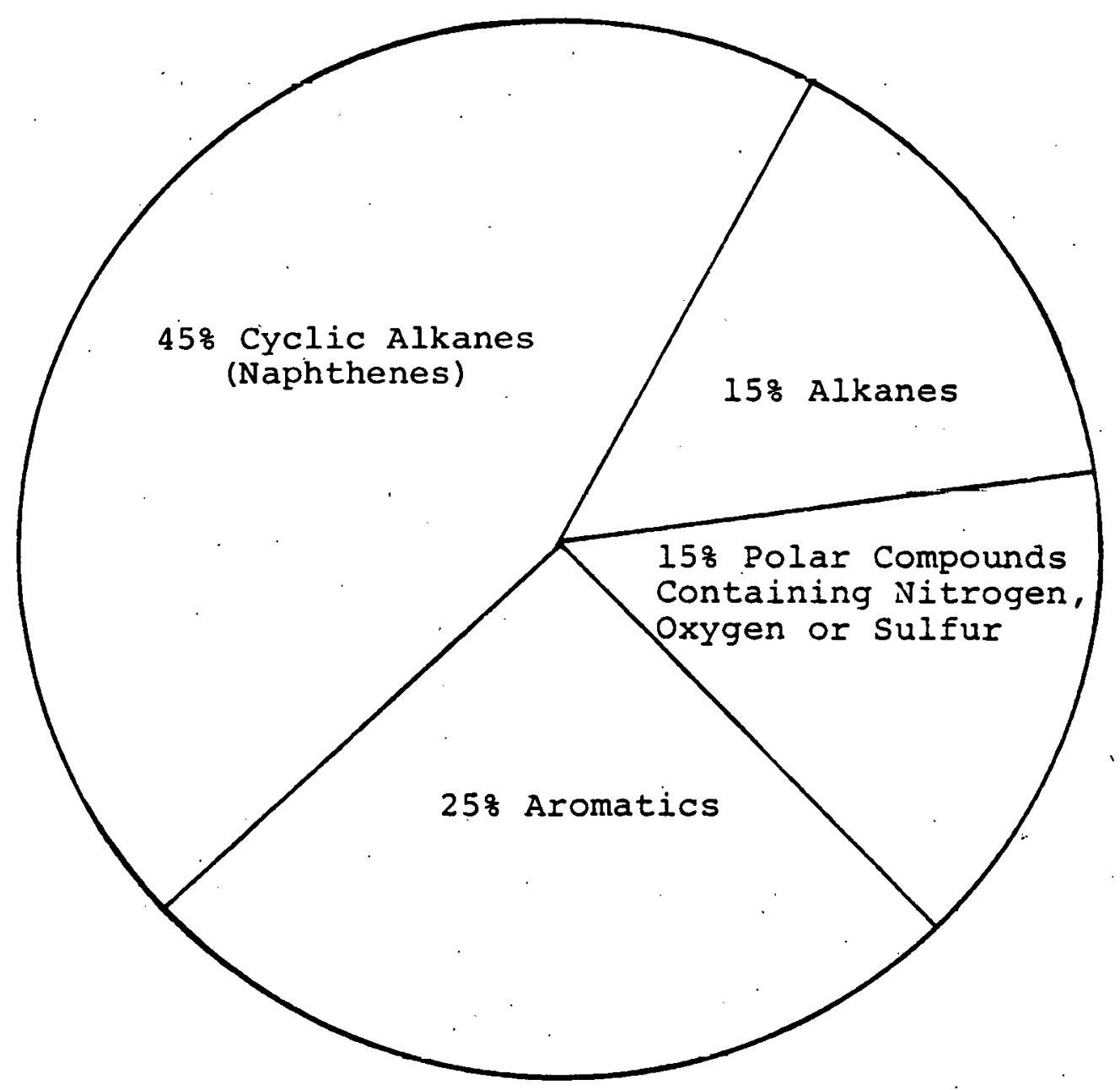

Source: - $\bar{N}$ ational Oceanic and Atmospheric Administration report ERL MESA-17, October 1977

API Report AID.1BA. 74, February 1974 
(4) Products From Two Indirect Coal Liquefaction Processes Are Inherently Clean And Therefore Are Not Analyzed In Relation To Direct Coal Liquefaction Products or No. 6 Fuel Oil

The two indirect processes currently in use today are: Fischer-Tropsch and Methanol synthesis. Both of these processes yield a liquefied product after gasification of the coal.

The Fischer-Tropsch process has been commercially operated in Germany and South Africa.

- The Fischer-Tropsch process produces a synthesis gas from coal by gasification with steam and oxygen. The gas is then purified and converted largely to aliphatic hydrocarbons over an iron or cobalt catalyst.

- In addition to being operated by Germany during World World II and South Africa since 1956, the process has been applied in the United States at:

.. Louisiana, Missouri--U.S. Bureau of Mines pilot plant operated in the early 1950's.

-. Brownsville, Texas--Commercial plant operated in the 1950's. 
- The product of the FischerTropsch process largely contains aliphatic hydrocarbons which are relatively safe from an environmental hazard perspective.

- Concentrations of potentially hazardous components such as heavy aromatic compounds in the product would be less than in No. 6 fuel oil.

-. In addition, the product would be essentially free trom sultur and nitrogen, presenting less air pollution concern on burning.

Methanol synthesis from coal produces a product with known hazards:

- There are a number of methanol synthesis processes utilizing various catalysts commercially available.

- The product is methanol. The hazards associated with methanol are we $\perp \perp$ documented and are presented in Exhibit $B-4$ on the foll nwing page.

- Methanol is considered environmentally safe when handled properly.

- The amount of impurities in methanol produced from coal in comparison to methanol produced from petroleum should be determined to assess the relative hazards. 


\section{EXHIBIT B-4 \\ Department of Energy \\ PUBLISHED HAZARDS ASSOCIATED \\ WITH METHANOL}

Explanation

Poisonous-regulated by Federal Hazardous Substances Act. "Cannot be made nonpoisonous. Vapor harmful, may be fatal or cause blindness if swallowed"

Ingestion

Inhalation

Dermal

Eyes

Carcinogenicity

Environmental

Physical and Chemical
Air pollution

Water/ground pollution

Explosion/fire
50-100 ml usually fatal dose Individual tolerances vary

$1000 \mathrm{ppm}$ causes irritation to eyes and mucous membranes $50,000 \mathrm{ppm}$ causes deep narcosis, possibly death

200 ppm is estimated upper tolerance limit for steady exposure

Usual effects are removal of grease and drying of the skin Methanol can be absorbed through the skin

Can cause blurring of vision, extreme sensitivity to light and inflamation

Lower than those of petroleum products due to absence of polynuclear aromatics

Combustion products are lower than those of petroleum fuels reduced carbon monoxide and hydrocarbon emissions, somewhat increased emissions of aldehydes

No sulfur oxides or soot are formed

Soluble in water, can be diluted, biodegradable with some bacteria (i.e. Pseudomonas fluorescens)

Flammability limits in air $7.3-$ $36 \%$ at STP;

Saturated vapor at $68^{\circ} \mathrm{F}$ contains 13\% methanol-explosive; flame arrestors and inert gas blankets may be necessary in handling 
EXHIBIT B-4

Department of Energy
Hazard

Type

Reactive

Regulatory Agencies
Explanation

Reacts vigorously with oxidizing agents

Coast Guard, Department of Transportation, International Air

Transport Association

Sources: SAX: Dangerous Properties of Industrial Materials; Society of Automotive Engineers;

Booz, Allen \& Hamilton, Inc. 
2. LIMITED ANALYTICAL OR QUANTITATIVE DATA ARE AVAILABLE FOR STUDYING THE PRODUCTS OF THE DIRECT LIQUEFACTION PROCESSES

In order to assess the hazard potential of direct coal liquefaction products, literature searches and personal interviews were conducted to obtain:

- Chemical analyses of the products

- Epidemiological data from previous or similar plants

- Biological data for the complete product mixture

- Analyses of combustion products.

It has been found that much work has been done on characterizing the hazardous properties of coal tars, runoff from coal wastes and coal residues of traditional coal processing plants.

Since the coal liquefaction industry is new, and the technology is developmental, the data used in this assessment of hazards are limited and at times incomplete. Judgments made are based on interviews with government, industry and union representatives and the best publicly available information.

(1) Chemical Analyses of The Products From Each Process Are Generally Unavailable

- The chemical components of coal

liquids contain numerous .complex molecules, with high boiling points, which are

difficult to analyze.

- There are estimated to be over 10,000 individual compounds in coal liquefaction products and also in No. 6 fuel oil.

- Compounds are presently characterized by their solubility and polarity. 
Analytical techniques are still being developed to analyze the chemical groups and compounds found in coal liquefaction products. These techniques use the following advanced analytical methods:

- Gradient elution chromatography

- Nuclear magnetic resonance

- Gel permeation chromatography

- Mass spectroscopy.

Data are reported in formats that are based on analyses developed for crude oil. These formats cannot be consistently used for comparison of coal liquefaction products as they usually specify only:

- Elemental analyses

- API gravity

- Other physical parameters

In general, analyses for polycyclic aromatics, sulfur compounds, nitrogen heterocyclics, monocyclic aromatics, invisyalicis alld insulubles must be interpreted from other data and are only qualitative in nature or are unavailable. The data are generally inconsistent. For example:

- An Exxon EDS analysis reports data on several different bases.

\footnotetext{
-. Sulfur, X-Ray,

Wt. percent

-. Mercaptan No. $\mathrm{mg} / 100 \mathrm{ml} \mathrm{--}$ proprietary test
} 

.. Phenol No. $\mathrm{mg} / 100 \mathrm{ml--pro-}$ prietary test
-. Aromatics, Wt. percent
.. Olefins, Wt. percent
.. Saturates, Wt. percent.

- An HRI H-Coal analysis gives a detailed analysis of two adjacent boiling point fractions $400-6500^{\circ} \mathrm{F}$ and $650-919^{\circ} \mathrm{F}$ in a different format.

.. Saturates, with chemical components in wt. percent

.. Unsaturated, nonaromatics, with chemical components in wt. percent

-. Aromatic compounds, with chemical components in wt. percent

-. Phenols, with chemical components in wt. percent

-. Non-hydrocarbon in wt. percent.

- A PAMCO SRC-II analysis shows the qualitative presence of individual polycyclic aromatic compounds, thiophenes and phenols. Other analyses are provided on an elemental basis. 
- The coal liquefaction plants are in the pilot stage which limits the amounts and consistency of product available for analysis.
- Operating conditions are experimental and still changing.
- Product availability is limited.

- Difficulties in analysis also arise from the need for pure analytical chemical standards for compound identification.

- Obtaining analytical standards is difficult with the great number of estimated compounds,

- Some compounds may be unique to coal liquefaction products and analytical standards may not exist.

(2) The Limited Epidemiological Data Available May Not Be Applicable To The Products of Current Direct Coal Liquefaction Processes

- Epidemiological data for coal liquefaction processes are available from the Institute, West Virginia liquefaction plant operated by Union Carbide during 1952-1960.

- The products of current direct liquefaction processes are expected to differ from the products produced by the Institute plant.

- Operating conditions (temperature and pressure) were more severe than current processing.

.. This generally produced more polycyclic aromatic hydrocarbons. 


$$
\begin{aligned}
& \text { The more aromatic } \\
& \text { product from the } \\
& \text { Institute plant is } \\
& \text { likely to be more } \\
& \text { hazardous than } \\
& \text { current products. }
\end{aligned}
$$

- Data collected was more relevant to the plant environment as a whole, rather than the product.

Worker hygiene programs in the current plants are expected to begin with the plant design and involve strict enforcement of personnel hygiene rules.

- The worker hygiene program at the Institute, West Virginia plant did not start until 1954, two years after the plant started up.

Exhibit B-5, on the following page, present.s epidemiological data at the plant, showing the incidence of skin lesions. The report from the plant medical director, Dr. Richard Sexton, M.D., on the control program and clinical effects, notes the following limitations:

- 359 men worked regularly in

the plant from May, 1952 to

February, 1960. This is a

small sample size

- Eight men of the 359 men working in the plant had nine cancers

- Some tumors were not pathologically examined

- Some tissue blocks were destroyed

- Consulting physicians disagreed concerning their diagnoses

- Some tumors were excised poorly because of early detection and their small size. 
EXHIBIT B-5

Department of Energy

SKIN CANCER HISTORY

INSTITUTE, WEST VIRGINIA LIQUEFACTION PLANT

Incidence of Skin Lesions Diagnosed in Coal Hydrogenation Process

Workmen with Nine Month' ' or More Exposure Between 1954 and 1959

Age Groups

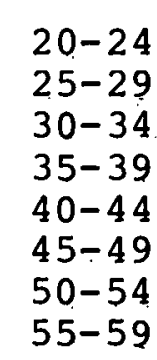

No. of Workers

12
60
103
75
50
30
7
5

Precan
0
5
9
6
12
3
6
1

No, of Caseg

$\begin{array}{rr} & \\ 0 & \text { Probable } \\ 5 & 0 \\ 9 & 1 \\ 6 & 3 \\ 12 & 3 \\ 3 & 3 \\ 6 & 1 \\ 1 & 0\end{array}$

0
1
3
3
3
1
0
0

Incidence $/ 100,000 /$ Year Probable

Plus Verified Verified only

Verified Cancer

\section{Crude}

Age-adjusted, West Virqinia

Age-adjusted, United States

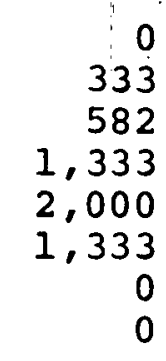

Mean Incidence

1,116

1,061

667

661

Precursors of Skin Cancer Cases

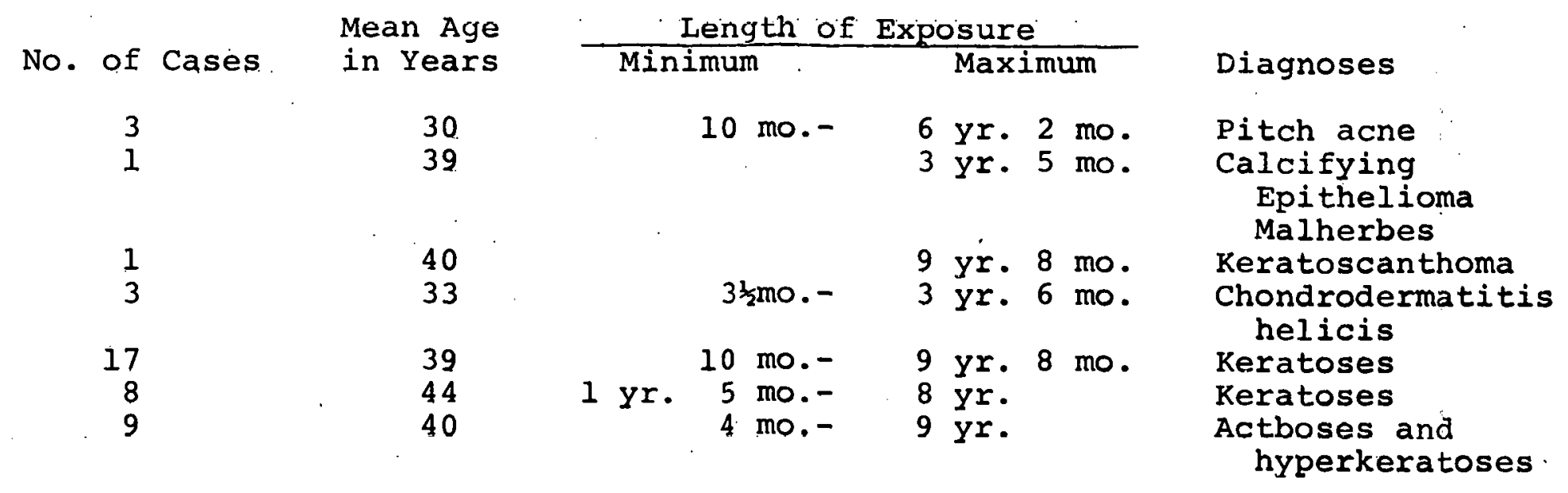

Source: Archives of Environmental Health, Sexton, R.J. "The Hazard to Health in the Hydrogenation of Coal;" Volume 1, 1960. 
- Epidemiological data are available for workers in the coal pitch and tar industries, but these data may not be applicable to direct coal liquefaction products.

- Coal pitches and tars have known health hazards.

- Some components in the products are similar, but concentrations are different.

- Handling characteristics of the products are different-solids and heavy oils vs. liquid for direct liquefaction products'.

- Similar epidemiological surveys for petroleum workers are currently underway. This will be useful for a future comparative hazard assessment.

- Present coal liquefaction plants have operated for too short a time to generate epidemiological data.
- Cancer has been known to develop from 7 to 65 years after exposure to coal tar and pitch.
- The SRC plant at Tacoma
Washington has been in opera- tion since January, 1974.
- No cancer traceable to the SRC plant operations has been reported.
- Epidemiological data would be ap- plicable to the processing plant. The product itself could not be judged on the basis of this data alone regarding end-use hazards.

(3) Biological Test Data Are Limited for Coal Liquefaction Products

- No information is currently available on the carcinogenic potential of the product as a whole. 
Biological data for coal liquefaction products are most applicable when the product as a whole is used for tests.

- The Pittsburgh and Midway Coal Mining Company (PAMCO) has developed a toxicological evaluation program consisting of:

- Acute tests to provide insight into the effects of short term exposures and to serve as a guide for further tests

- Inhalation and dermal carcinogenesis surveys which evaluate the potential skin

- and respiratory cancer hazard associated with long term exposures to SRC materials

- Subacute and special intermediate tests which evaluate potential teratogenic effects.

Unfortunately, this program was to be carried out at Industrial Bio Test Laboratories (IBT), which is virtually shut down because of action by the EPA, based on questionable validity of previous tests performed. The SRC-II program status is unknown.

The Department of Energy is sponsoring biostudies at Battelle-Pacific Northwest Laboratories, using SRC products.

- The AFL-CIO and the OCAWU are only now beginning to study the effects of the products on worker safety and health. Their prime concern is for workers in the plant and the effects of accidents such as valve blowouts on worker exposure.

Preliminary biotesting is being performed by Oak Ridge National Laboratories on $\mathrm{H}-\mathrm{Coal}$ and EDS Liquids. The products being tested are not considered representative of the final product. 
(4) Test Burn Data are Available but Limited Because of Short Test Duration and Brief Analyses Ferformed

Two test burns have been conducted on SRC-II coal liquids.

- The Pittsburgh Energy Research Center conducted preliminary tests on a 100 horsepower fire tube boiler.

- The Electric Power Research Institute, Consolidated Edison Company of New York, and the New York state ERDA (in cooperation with the U.S. Department of Energy) conducted a five-day test burn ousing 4,500 barrels of SRC-II fuel oil in a commercial tangentially fired utility boiler.

- A detailed report on the Consolidated Edison test burn notes several limitations for projecting data from the test.

- The test was based on the characteristics of the SRC-II composite fuel used--it was a composite made from three separate coals.

- The test results relate sperifically to the type of tangentially fired boiler used by Con Ed.

- The limited number of polycyclic organic matter (POM) samples and uncertainties in the combined sampling/ extraction/analysis show the need for caution in interpreting results.

- The limited amount of SRC-II fuel used in the test burn did not allow time to optimize the combustion hardware. Differences anticipated from a more optimum design were judged to be relatively minor. 
3. OUR APPROACH TO DETERMINING THE POTENTIAL HAZARDS OF

DIRECT COAL IIQUEFACTION PRODUCTS WAS TO COMPARE

CHEMICAL GROUP INGS AT FOUR LEVELS OF ANALYSIS:

ULTIMATE ANALYSIS; CHEMICAL GROUPS; CHEMICAL COMPOUNDS;

AND TRACE ELEMENTS

Though existing analyses of the products are few and subject to the limitations previously discussed, a step-wise, four-level review using the best available data allows informed judgments to be drawn on worker safety and health and environmental impacts of direct coal liquefaction products. These conclusions are drawn from the knowledge of the effects of similar chemical groupings found in products from other industries where hazards are known. The levels of analysis were chosen because information is available for direct liquefaction products in those formats. Identical analyses for each of the three processes under review are unavailable in the same format when compared to similar analyses of No. 6 fuel oil.

We chose these four levels of analysis because:

Combustion products can be predicted from the ultimate analyses and can be used to develop comparative emissiun data.

- Groups of known or suspected carcinogens and toxic chemicals can be identified and compared by relative concentrations.

- Toxicity and carcinogenic potentials of direct coal liquefaction products and No. 6 fuel oil can be compared by determining the relative concentrations in each product of the more common hazardous chemical compounds that are usually identified with coal conversion products. 
(1) Worker Safety And Health Effects Can Be Approximated Based On The Four Levels of Analyses

The four, levels of analysis, as illustrated in Exhibit B-6, can be used to assess the potential biological hazards of direct coal liquefaction products for:

- Toxicity

- Carcinogenicity

- Mutagenicity

- Teratuyenicily

A description of the biological effects specified by these terms is found in Appendix $B-3$.

- Ultimate analyses (sometimes called elemental) for carbon, hydrogen; nitrogen, sulfur and oxygen can be used to determine some general characteristics of the products.

- The carbon to hydrogen ratio gives an indlcation of the high or low boiling nature of the product.

- High sulfur, nitrogen and oxygen contents generally indicate more toxic and carcinogenic properties of the products.

- Sulfur and nitrogen can be used to assess $\mathrm{SO}_{x}$ and $\mathrm{NO}_{x}$
emissions.

A general characterization of the probable hazards from chemical groups is described in Exhibit B-7. This type of analysis provides a method for associating direct coal liquefaction products with known hazards of various chemical grouping. 


\begin{abstract}
EXHIBIT B-6
DEPARTMENT OF ENERGY

ANALYSIS GROUPINGS AND THEIR POTENTIAL FOR

ESTIMATING HAZARDS TO WORKER HEALTH AND SAFETY
\end{abstract}

Grouping

Ultimate analysis (elemental composition)

Trace elements

Chemical groups

Chemical compounds
Hazard Estimating Potential

Emissions from combustion $-\mathrm{SO}_{\mathbf{X}}, \mathrm{NO}_{\mathbf{X}}$ and particulates

Toxicity, reactivity and corrosivity

Carcinogenicity, toxicity mutagenicity

Carcinogenicity, toxicity, mutagenicity, teratogenicity particulate emissions

Source: Booz, Allen \& Hamilton Inc. 


\section{EXHIBIT B -7 \\ Department of Energy \\ CHARACTERIZATION OF PROBABLE CHEMICAL HAZARDS IN BOILER FUELS FROM COAL \\ LIQUEFACTION PRODUCTS}

\begin{tabular}{|c|c|c|}
\hline $\begin{array}{l}\text { Chemical } \\
\text { Group }\end{array}$ & Examples & Effects \\
\hline Polycyclic aromatics & $\begin{array}{l}\text { Naphthalenes, anthra- } \\
\text { cenes, benzanthra- } \\
\text { cenes, pyrenes, benzopy- } \\
\text { renes, indenopyrenes } \\
\text { chrysenes, benzofluor- } \\
\text { anthenes }\end{array}$ & Toxic, carcinogen \\
\hline Sulfur compounds & $\begin{array}{l}\text { Mercaptans, thiophenes } \\
\text { thioureas, sulfonic } \\
\text { acids }\end{array}$ & $\begin{array}{l}\text { Irritant; toxic, sus- } \\
\text { pected carcinogen, } \\
\text { mutagen }\end{array}$ \\
\hline Nitrogen heterocyclics & $\begin{array}{l}\text { Pyridines, indoles, } \\
\text { carbazoles benzcar- } \\
\text { bazules, quinulines, } \\
\text { morpholines, diben- } \\
\text { zacridines, phena- } \\
\text { zines }\end{array}$ & Toxic, carcinogen \\
\hline $\begin{array}{l}\text { Nonheterocyclic nitro- } \\
\text { gen compound }\end{array}$ & $\begin{array}{l}\text { Amines, amides, imines } \\
\text { hydrazines, semicarba- } \\
\text { zides azo compounds }\end{array}$ & $\begin{array}{l}\text { Toxic; carcinogen, } \\
\text { mutagen }\end{array}$ \\
\hline Monocyclic aromatics & $\begin{array}{l}\text { Phenols, xylenols, } \\
\text { cresols }\end{array}$ & $\begin{array}{l}\text { Irritant, toxic, } \\
\text { suspected carcinogen }\end{array}$ \\
\hline Inorganics--elements & $\begin{array}{l}\text { Arsenic, bromine, } \\
\text { eesium, lanthanum, } \\
\text { cobalt, mercury, } \\
\text { todine, sulfur, } \\
\text { yttrium, ytterbium }\end{array}$ & $\begin{array}{l}\text { Toxic, . irritant, } \\
\text { carcinogen }\end{array}$ \\
\hline Inorganics--compounds & $\begin{array}{l}\text { Antimony trioxide } \\
\text { Diarsenic trioxide } \\
\text { Barium carbonate } \\
\text { Boron oxide } \\
\text { Cadmium sulfide } \\
\text { Cyanide } \\
\text { Metal chromates } \\
\text { Copper sulfate } \\
\text { Gold salts } \\
\text { Lead chromate } \\
\text { Potassium chromate } \\
\text { Selenium metal complex } \\
\text { Silver salts } \\
\text { Sodium vanadate } \\
\text { Zinc sulfide }\end{array}$ & $\begin{array}{l}\text { Carcinogens, toxic, } \\
\text { irritant, corrosive }\end{array}$ \\
\hline
\end{tabular}

Source: U.S. Department of Energy, Contract No. Ex-76-C-01-1795, Assessment, Selection and Development of Procedures for Determining the Environmental Acceptability of Synthetic Fuel Plants based on Coal, May 1977 
- Many polycyclic aromatics are known to be carcinogenic. It has been noted that the heavier molecules, particularly the 4,5 and 6 ring aromatics, have the strongest carcinogenic properties.

- Nitrogen heterocyclics and sulfur compounds can contain some known or suspected carcinogens and are moderately toxic. Since these nitrogen and sulfur compounds are generally more water soluble than polycyclic aromatics, only small concentrations are expected in the products.

- Monocyclic compounds can be classified as moderately to very toxic, (ratings by Gosselin et al. 1976) and contain some carcinogens.

- Inorganic elements and compounds have known individual toxicity and carcinogenicity. ratings. Some are non-toxic and non-carcinogenic.

Health hazards for some individual chemical compounds found in direct coal liquefaction products are known. Exhibit B-4 provides the potential health effects for several of these compounds and can be used qualitatively to assess the comparative hazardous nature of the products. The quantities involved, however, are often small.

The inorganic compound analysis is also useful in assessing the toxicity and carcinogenicity of coal liquefaction products. Exhibits $\mathrm{B}-4$ and $\mathrm{B}-5$ provide insight into hazards of particular elements and compounds that can be found in coal liquefaction products. Some of these compounds are among the most toxic known to man (e.g., cyanide). These compounds are, however, usually found only in trace quantities (less than $500 \mathrm{ppm}$ ). Their presence is related to the presence of trace elements in the mother coal. 
Trace elements are found in coal liquefaction products in extremely small quantities. Many of the elements found have been known to cause toxic symptoms in humans who are exposed to larger quantities. Some of these trace elements, or compounds associated with them, have also been known to accumulate in various organs and cause disease.

(2) Environmental Effects Can Also Be Approximated From These Analyses

Air pollution effects can be estimated by the ultimate chemical compound and trace element analyses assessed relative to No. 6 fuel oil.

- $\mathrm{SO}_{\mathrm{X}}$ and $\mathrm{NO}_{\mathrm{X}}$ emissions can be approximated by the elemental analysis of sulfur and nitrogen.

NOTE: $\mathrm{SO}_{\mathrm{x}}$ and $\mathrm{NO}_{\mathrm{x}}$ emissions approximated by the elemental analysis of sulfur and nitrogen may not be completely representative since:

- $\mathrm{NO}_{\mathrm{x}}$ is a function of fuel nitrogen, thermal conversion of $\mathrm{N}_{2}$ to $\mathrm{NO}_{\mathrm{x}}$ in the hot flame zone, $\therefore$ excess $\mathrm{O}_{2}$ in the boiler and boiler design.

- Assuming $\mathrm{NO}_{\mathrm{X}}$ emissions on fuel $\mathrm{N}_{2}$ is not sompletely representative.

- Particulate emissions can be approximated by the Carbon to Hydrogen ratio.

- Ashes will depend on trace elements found in the product.

- Polycyclic aromatic hydrocarbon emissions may depend on polycyclic aromatics in the product.

- Vapors released by the product depend on the chemical compounds and physical characteristics of the product which can be approximated from the ultimate analysis. 
- Water pollution effects can be assessed by evaluating the chemical compounds in the products and the trace element-and inorganic analyses of the products relative to No. 6 fuel oil.

- Ground contamination will also be assessed by the chemical compounds, trace element and inorganic analyses of the products relative to No. 6 fuel oil.

- Exhibit B-6 shows the significance of some elements known to cause problems in utility boiler operations.

4. THE ENVIRONMENTAL HAZARDS FOR DIRECT COAL LIQUEFACTION PRODUCTS WERE ASSESSED FOR BOTH ROUTINE AND EPISODAI. EVENTS

To evaluate the environmental hazards associated with coal liquefaction products, we studied each of the routine tasks and potential episodal events that could be associated with the product once it left the liquefaction plant gate. This analysis was performed only for the boiler fuel product, not byproducts, refinery streams, or waste streams.

- Exhibit B-8, on the following page, presents routine tasks that were evaluated and the potential environmental impact areas associated with each task.

- Exhibit B-9, following Exhibit B-8, presents episodal events that were evaluated and the potential environmental impact areas associated with. each event. 
EXHIBIT B-8
Department of Energy

ROUTINE TASKS AND THE POTENTIAL ENVIRONMENT

IMPACTS OF USING COAL LIQUIDS

Potential

Routine Tasks

Loading

Transport

Unloading

Storage

Cleanup and maintenance of equipment used above

Sampling and analysis

Precombustion processing

Combustion

Residue disposal--oil ash, furnance deposits

Maintenance

Chemical cleaning
Environmental Impact

Worker exposure to liquids and vapors

Worker exposure to liquids, vapors and residues.

Worker exposure to liquids and vapors

Minimal--closed system

Worker and population exposure due to fly ash, incombustible organics, inorganics and trace elements

Worker exposire to solid deposits of incombustible organics, inorganics and trace elements

Worker exposure to liquids, vapors, residues and incombustible organics, inorganics and trace elements

Worker exposure to liquids, vapors, residues and solvents

NOTE: It is assumed that disposal of wastes from the cleaning and residue disposal operations is performed in accordance with approved procedures.

Source: Booz, Allen \& Hamilton Inc. 


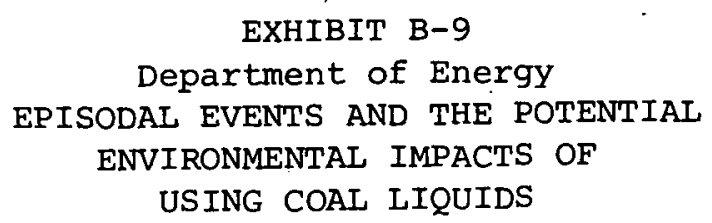

Routine Task

Loading

Transport

Unloading

Storage

Cleanup and maintenance of equipment used above

Sampling and analysis

Precombustion processing

Combustion

$$
\text { . }
$$

Residue disposal--

oil ash, furnace

deposits

Maintenance

Chemical cleaning
Episodai Event

Accidents/spills/

disasters

Accident/spills

Accident

Leaks/ruptures

Incomplete combustion

Accident

Accident

Accident
Potential

Environmental Impact

Worker exposure

Air pollution

Water pollution

Ground pollution

Fire/explosion

Public health

Worker exposure

Water pollution

Ground contamination

Worker exposure

Worker exposure

Air pollution

Water pollution

Ground contamination

Fire/explosion

Air pollution

Worker exposure

Public Health

Worker exposure

Ground contamination

Water pollution

Worker exposure

Ground contamination

Water pollution

Worker exposure

Ground contamination

Water pollution

Air pollution

Fire/explosion

Source: Booz, Allen \& Hamilton Inc. 
5. GIVEN THAT THE COAL LIQUEFACTION PRODUCTS START WITH A SIMILAR COAL AND BECAUSE OF PROCESS SIMILARITIES, THEY PRESENT SIMILAR RELATIVE HAZARDS

(1) There Are Basic Similarities Among The Processes And Their Operating Conditions

The H-Coal process is a catalytic hydroliquefaction process developed

by Hydrocarbon Research Inc. The plant can operate in either of two modes: a fuel oil mode or a synfuel mode. The differences between the modes are primarily in the severity of operating conditions and the degree of hydrogenation. A plant under construction in Cattletsburg, Kentucky, expects the ebillilating hed reartor process operating conditions to be 2,600 psi at a temperature of $370^{\circ} \mathrm{C}$.

The EDS process is a noncatalytic coal liquefaction process (catalysts are used for saturating the solvent and upgrading products) developed by Exxon, Inc. Dried and ground coal is mixed with donor solvent recovered from the process. The slurry is reacted with a hydrogen-rich gas at about $380^{\circ} \mathrm{C}$ and 2800 psi. This reaction. produces a mixture of gaseous, liquid and solid products which. are further processed. The products are separated and the Iiquids are further hydrotreated. The donor solvent is also regenerated in this step. 
The SRC-II process is a noncatalytic hydroliquefaction process under development by the Pittsburgh and Midway Coal Mining Company, a subsidiary of Gulf Oil Corporation. The process involves slurrying the coal in a process-derived solvent and hydrogenating the mixture at a temperature of $457^{\circ} \mathrm{C}$ and at pressure of 2,000 psi. Hydro treating of the liquid product is continued to remove sulfur and other impurities. 'the severity of conditions and variances in hydrogen consumption can change the characteristics of the product.

Exhibit B-10, on the following page, shows the similarities of the three processes, operating conditions and yields. Important similarities to note are:

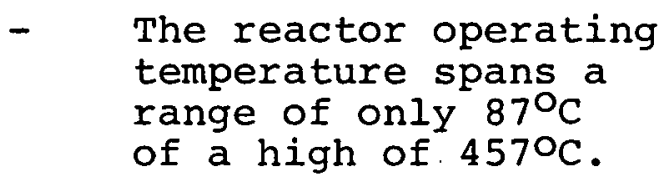

- Operating pressures span only 800 psi out of 2,800 psi.

- All three processes are still under development; therefore operating conditions are subject to change and will probably overlap each other at times.

Exhibit B-11, following Exhibit B-10, compares the "traditional" unit operations of the three processes.

- Five of the eight unit operations noted are the same. 


\section{,}

EXHIBIT B-10

Department of Energy

HYDROLIQUEFACTION OPERATING CONDITIONS

OF THE THREE DIRECT COAL LIQUEFACTION PROCESSES
Condition

Reactor temperature, ${ }^{\circ} \mathrm{C}$

Reactor pressure, psi

Yield (Bbls/ton dry coal)

\begin{tabular}{|c|c|c|c|}
\hline \multicolumn{4}{|c|}{ Process } \\
\hline H-Coal & SRC-II & Exxon Donor & Solvent \\
\hline 370 & 457 & 380 & \\
\hline 2,600 & 2,000 & 2,800 & \\
\hline
\end{tabular}

1.7

1.7

1.5

Source: EPA Report No. EPA-600/7-78-1849; Environmental Assessment Data Base for Coal Liquefaction Technology, Volume I, Systems for 14 Liquefaction Processes, U.S. Department of Energy, Booz, Allen \& Hamilton Inc., August 1978 
EXHIBIT B-i

Department of Energy

?ROCESS SINITARITIES OF THE THREE

DIRECW COAL IIQLEEACTION PROCESSES GNDER REVIEW

Unit Doeretion

Coal preparation

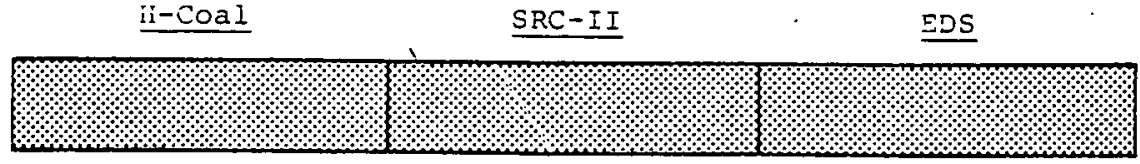

Hyarogenation

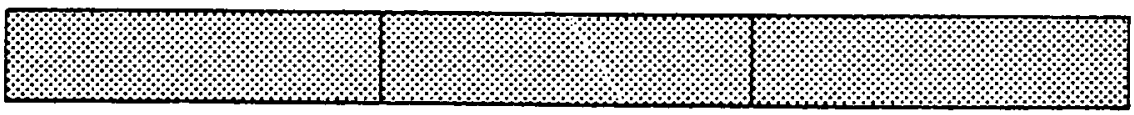

Pyarocreating

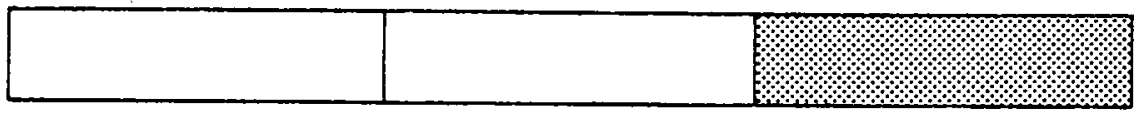

Catalytic synthesis

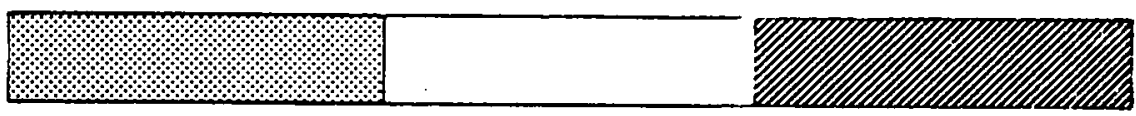

Phase separation

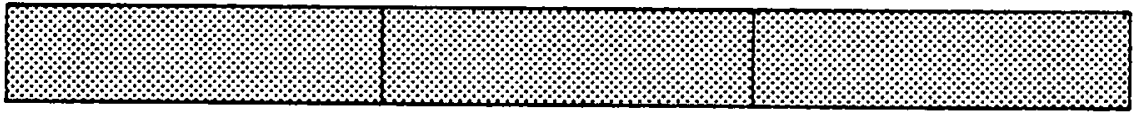

Fracticnation

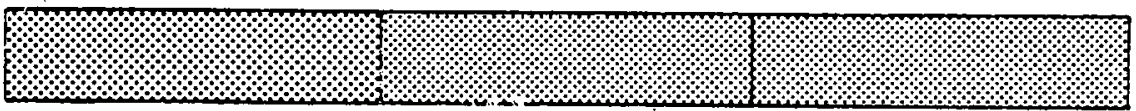

Gas cleaning

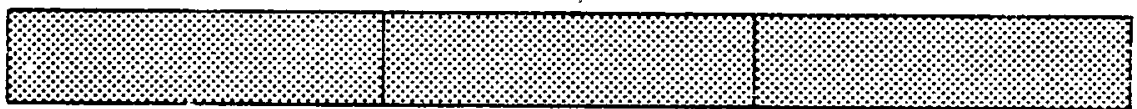

Hydroger,'synthesis gas generation
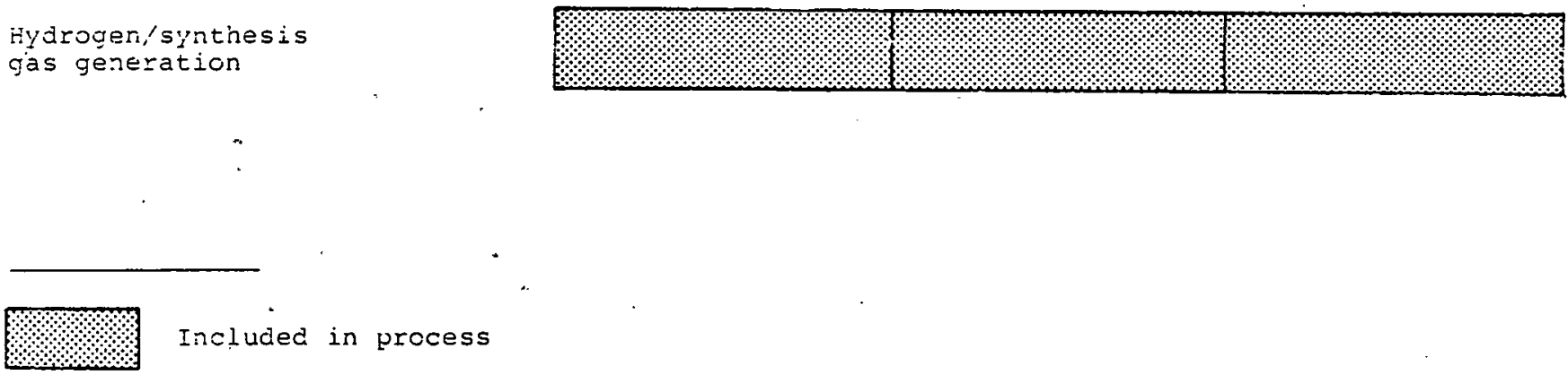

Included in process

Hocifieà process

Not used

Source: EPA Report No. EPA-600/7-78-184a; Environmental Assessment

Data Base for Coal Liqueraction Technology, Volume I,

Systems for 14 Liquefaction Frocesses, Alicust $1973 ;$ Booz

a.llen \& Hamilton Inc. 
- Though hydrotreating is noted only for the EDS process, the degree of hydrogenation for each of the processes is variable.

- Though the SRC-II process uses no additional catalyst, recycle of the product stream causes the impurities of the coal itself to be a catalyst.

- Because of the dual mode operation capability of the H-Coal plant, a product fractionation unit is not included. However, streams are distilled into heavy and light ends.

Analyses of The Products Are Limited, But Similarities Can Be Seen Among The Available Information

Ultimate analyses have been provided by the Department of Energy for the various direcL liquefaclion producls. Graphic representation of these analyses is shown in Exhibit B-12, on the following page. Basic similarities exist for the coal liquefaction products' elements shown, even though the SRC-II analysis. in this case is based on Kentucky $9 / \overline{1} 4$ coal.

Detailed chemical group and compound analyses are available only for $\mathrm{H}$-Coal.

A similar chemical group and compound analysis (ERDA Contract No. W-7405eng-26, Environmental Health and Control Aspects of Coal Conversion, April 1977) gives only qualitative data for chemical groups and compounds found in SRC-II fuels; it also notes the presence of many of the same compounds. 
Distillation Range

No. 6 fuel oil

H-Coal

SRC-II

EDS

\section{Specific Gravity}

No. 6 fuel oil

$\mathrm{H}-\mathrm{Coal}$

SRC-II

EDS

Elemental Composition Carbon

No. 6. fuel oil

$\mathrm{H}-\mathrm{Coa} 1$

SRC-II

EDS

\section{Hydrogen}

No. 6 fuel oil

$\mathrm{H}-\mathrm{Coal}$

SRC-II

EDS
EXHIBIT B-12(1)

Department of Energy

SPECIFICATIONS AND ELEMENTAL ANALYSES OF THE THREE COAL LIQUEFACTION PROCESSES

AND NO. 6 FUEL OIL
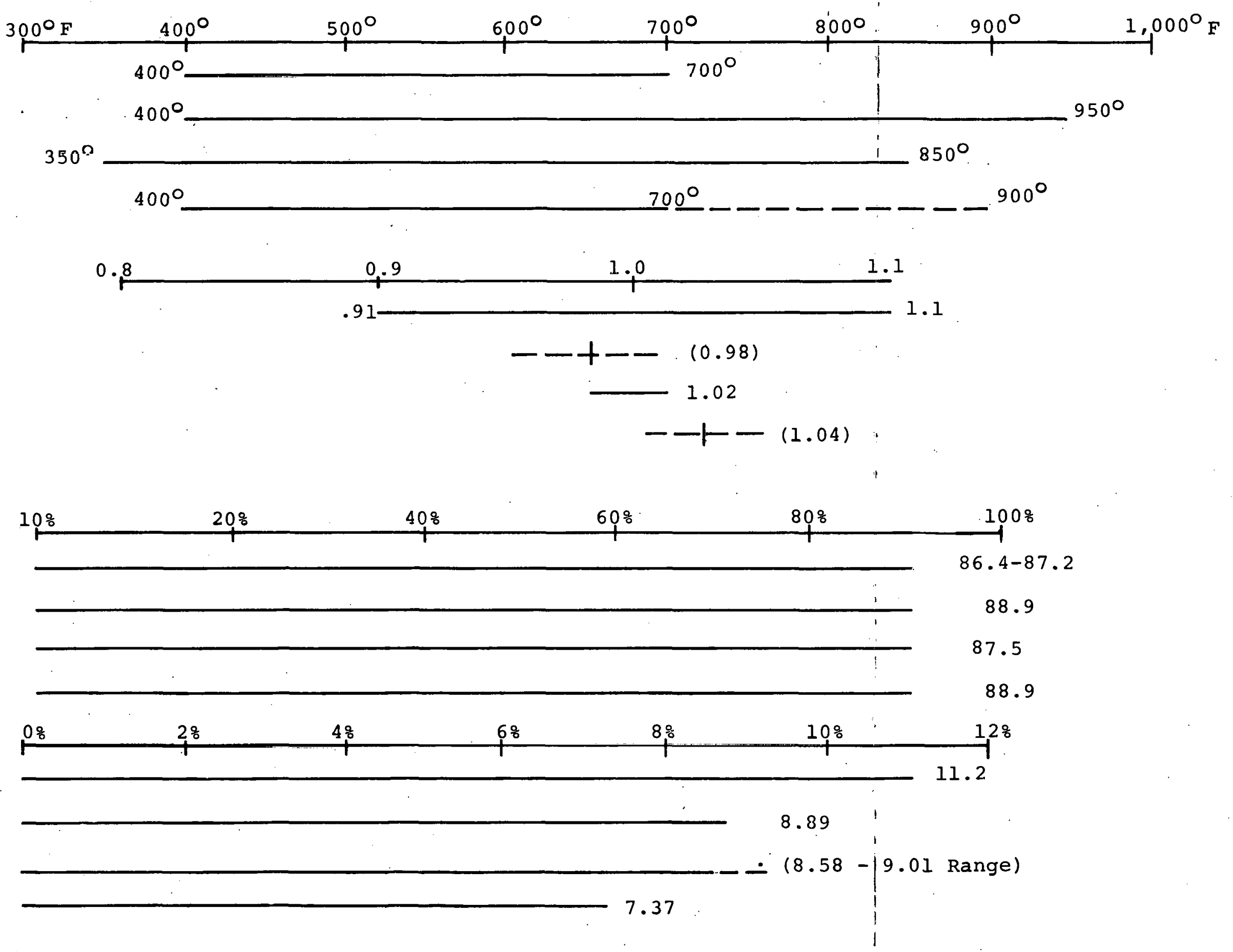
EXHIBIT B-12 (2)

Department of Energy

Sulfur

No. 6 fuel oil

$\mathrm{H}-\mathrm{Coal}$

$S R C-I I$

EDS

Nitrogen

No. 6 fuel oil

$\mathrm{H}-\mathrm{Coal}$

SRC-II

EDS

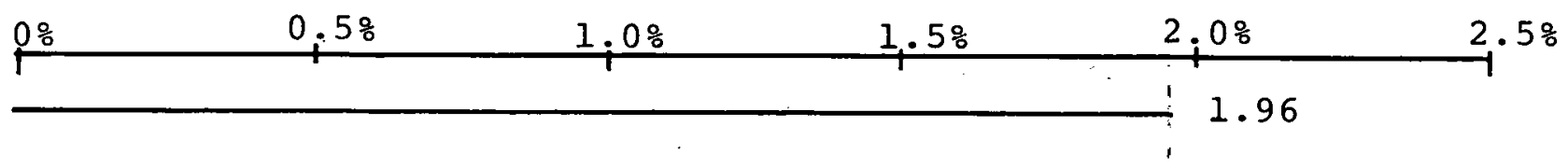

$-0.19$

$-0.23$

$\longrightarrow 0.5$

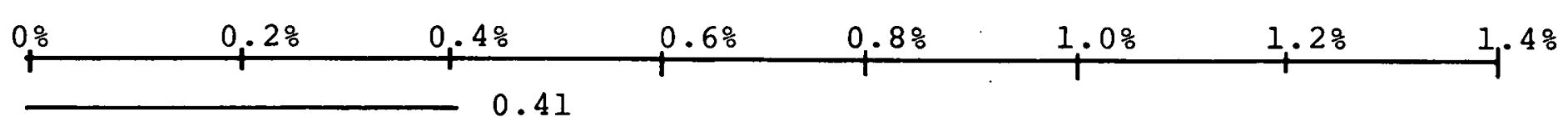

0.41

NOTE: H-Coal produced from Kentucky 9/14 coal.

Source: American pétroféum theltute

U.S. Departinite $\sigma f$ Energy

Electintic Power Research Institute

Booz, Allen \& Hamilton Inc. Analysis 
- Mass spectrometry has been done by PAMCO on the light oil fraction; analyses of the light oil also show similar chemical groups and compounds.

- No similar analyses are available for the EDS product.

(3) The Use of The Same Source of Coal For Each Process Provides A Common Basis For Comparison Of Direct Coal Liquefaction Products To No. 6 Finel nil.

- The composition of the direct liquefaction products is likely to vary with the source of coal selected.

- The composition of sulfur and trace elements in the direct coal liquefaction products will be the most greatly affected by variations in the feed coal.

- These trace elements can affect.the carcinogenicity and toxicity of coal liquefaction products.

- The sulfur content can affect coal liquefaction product toxicity and the emissions from product combustion.

- More data are needed to compare products from the various processes using different coals.

- In our opinion, the relative ranking of the potential environmental hazards of the three processes is probably related more to the coal feedstock than the three processes themselves. However, the findings presented in this chapter probably would not change if another type of coal were selected as a feedback.

(4) Based On The Available Data, The Hazards of The Three Processes Cannot Be Judged Relative To Each Other, But Only In Relation To No. 6 Fuel Oil

The similarities among processes and their products indicate that the hazards from the products of the direct 
liquefaction processes cannot be differentiated well enough to cite differences among the individual products.

- The combined analyses of the products from the three processes yield enough information to provide a basis for comparison with No. 6 fuel oil. 
6. DIRECT COAL LIQUEFACTION PRODUCTS ARE POTENTIALLY MORE HAZARDOUS TO WORKERS THAN NO. 6 FUEL OIL

Analyses of the products of direct coal liquefaction, in terms of both component chemical groups and chemical compounds, show that there are greater concentrations of hazardous components when compared to No. 6 fuel oil. Based on this finding, coal liquids can be relative classified more carcinogenic than No. 6 fuel oil.

The significance of this analysis must be tempered by restating that analyses for No. 6 fuel oil are based on wide variations in composition and limiter data. Additionally, interviews conducted ard som of the literature reviewed indicate that the coal liciuefaction products in their entirety are less toxic and tumorigenic than would be expected from an examination of their components.

Biological studies on the coal liquefaction products, in their entirety, are needed to confirm our analysis.

(1) Direct Coal Liquefaction. Products May Be Judged To Be lore Carcinogenic Than No. 6 Fuel oil

Comparison of the chemical groups found in coal liquefaction products to those contained in No. 6 fuel oil, Exhibit B-13, on the following page, shows that:

- There are approximately two to three times more polycyclic aromatic hydrocarbons in coal liquids than in No. 6 fuel oil.

- Polyaromatic hydrocarbons contain known carcinogens such as benz(a) pyrene and various chrysenes.

Exhibit B-14 presents a comparison of chemical compounds which provides a further basis for the judgement that direct coal liquefaction products could be more carcinogenic than No. 6 fuel oil:

- Direct coal liquefaction products have approximately twice the concentration of alkyl benzenes as the No. 6 fuel oil has benzenes. 
EXHIBIT B-13

Department cf Energy

CHEMICAL GROUES FOUND IN

CONL LIQUEFACTION PRODUCTS AND

NO. 6 FUEL OIL

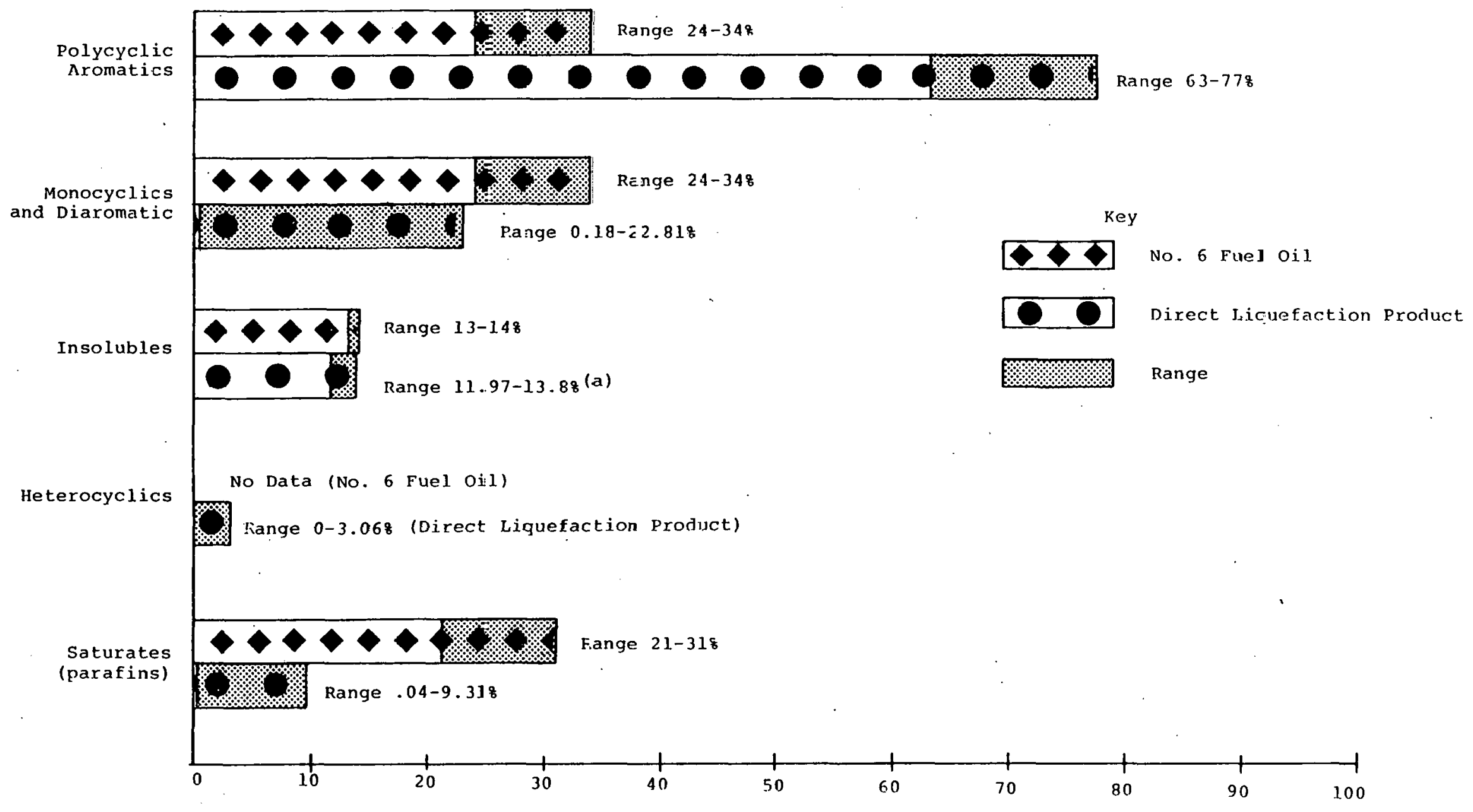

(a) Nonhydrocarbons

Weight Percent

Sources: EPA Report EPA 600/7-7B-184b: Environmental nssessment Data Base tor Coal Liquefaction Technology, Volume II September, 1978; Hobile Research and Development Corporation-- $n$ nalysis by Booz, $\mathrm{Allen} \&$ Hamilton Inc.: API report AID IBA.74 February 1974; Hational Oceanic and Atmospheric Administration--report ERL :IFSA-17 OCtober, 1977 Bartlesville Energy Research Cente 


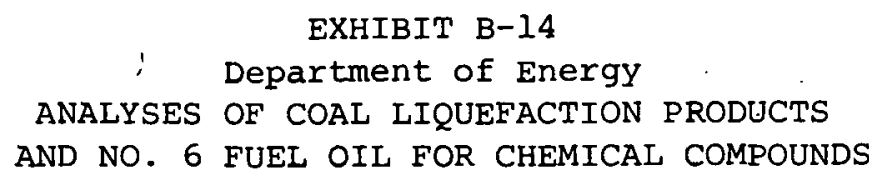

Compound

$\frac{\text { No. } 6 \text { Fuel oil }}{(\text { Wt. } 8)}$

Direct Liquefaction

Products

Aromatics and cyclic alkanes

32

(Wt. 8)

Benzenes

1.9

70

Alkyl benzenes

ND

ND

Indans/tetralins

$2 \cdot 1$

4.6

Indenes

Dinaphthene benzenes

Naphthalenes

ND

5.77

2.0

2.6

3.1

Acenaphthenes

7.0

Acenaphthalenes

11.6

Phenanthrenes

ND

$\cdot 1.7$

0.99

Benzphenanthrenes

Pyrenes

Chrysenes

0

ND

18.48

1.08

ND

23.21

4.3

4.67

7.1

Thiophenes

Benzothiophenes

Dibenzothiophenes

1.5

0.7

$1-2$

Indanothiophenes

0

Phenols

0

1.59

Insolubles (inorganics)

14.4

11.97

Note: ND--No Data

Sources: American Petroleum Institute Report, No. AlD. 1BA. 74, ERDA contract No. W-7405-eng-26, April 1977

EPA Report EPA-600/7-78-1846; Environmental Assessment Data Base for Coal Liquefaction Technology: Volume II, september 1978 Booz, Allen \& Hamilton Inc. 
- Approximately two to three times the concentration of Indans/tetralins as No. 6 fuel oil.

- Approximately three times the concentration of Pyrenes as No. 6 fuel oil.

- Coal liquid products contain over seven percent chrysenes; no chrysenes were found in the No. 6 fuel oil tested.

(2) Direct Coal Liquefaction Products Are Probably More Hazardous Than No. 6 Fuel Oil

The comparatively greater amounts of polycyclic aromatic hydrocarbons are primarily responsible for the judgment of increased toxicity of direct coal liquefaction products. Approximately 70 percent of direct coal liquid products are made up of polycyclic aromatic hydrocarbons compared to approximately 25 percent for No. 6 fuel oil.

- A small contradiction exists because the higher elemental sulfur composition of No. 6 fucl oil indicates that it may be more hazardous than direct coal liquid products. Fuel oil contains appruxillalely two to ten times the amount of sulfur as the rnal liquids. However, the low absolute concentration of three percent is less significant than the pulycyclic aivmatic hydrocarbon concentration differences.

- A comparison of trace elements, indicates that:

- A higher Vanadium content exists in No. 6 fuel oil.

- Minimal health effects would result from the low concentration of Vanadium. 
The insoluble fractions of both direct coal liquefaction products and No. 6 fuel oil are approximately the same concentration. This fraction contains trace elements and inorganic compounds that would contribute to the product toxicity.

(3) Dermal Contact Will Be The Primary Exposure Route of Concern

- Coal liquefaction products used for boiler fuel are the high boiling fractions of the synthetic fuel mixtures. The distillation temperature range varies from 350-850\% $\mathrm{F}$.

- The known carcinogens in the products are primarily the polycyclic aromatic hydrocarbons which have low vapor pressures and do not volitalize rapidly. Thus, dermal contact as opposed to inhalation becomes the primary concern.

- The nitrogen heterocyclics and sulfur compounds also have relatively low vapor pressures; only small concentrations of these compounds would be present.

- Exposure of individuals will most likely come from dermal contact with the product.

- The epidemiological study done on the Institute, West Virginia plant noted no incidence of systematic cancer. This indicates that vapors and liquids, properly coñtrolled will not present internal health hazards.

- Dermatitis, lesions and latent carcinogenic tumors can result from continued dermal exposure to direct coal liquefaction products. 
Suitable protection and good hygiene practices will be necessary to protect workers from exposure to direct liquefaction products.

(4) A NIOSH Criteria Document For Coal Gasification Plants Has Been Issued And Can Be Used As A Guideline For Handling of Coal Liquefaction Products

- NIO3H is currently studying coal liquefaction plants and will issue either a criteria document or a position paper.

- The NIOSH coal gasification document is based in part on control measures taken in previous coal liquefaction plants. Also many similarities exist between coal liquefaction and gasification plants. Therefore, procedures recommended by the gasification document can be used as a guideline for handling of direct coal liquefaction products.

- The NIOSH coal gasification criteria document provides recommendations for health and safety standards for occupational exposures. It includes:

- Safety procedures

- Engineering control objectives

- Work practices

- Workplace monitoring

- Medical surveillance

- Personal protective clothing and equipment

- Sanitation

- Labeling and posting

- Employee awareness. 
The document also presents a review of the biological effects of potenital health hazards, including:

- A discussion of the coal liquefaction pilot plant at Institute, West Virginia.

- A followup study done on workers from the plant.

The study of the coal liquefaction plant indicates that "SKIN cancer incidence was at least 20 times as high as the expected incidence".

The followup study noted that the group was not at an increased risk of SYSTEMIC cancer.

According to NIOSH, no other report of increased skin cancer has been found in coal gasification or liquefaction plants.

NIOSH recommends a comprehensive employee protection program that may be applicable to handlers of direct coal liquefaction products. This program follows:

- Medical Surveillance

- Preplacement medical examination

- Periodic examination

. Records of employee exposures

- Personal protective clothing and equipment.

.. Impervious gloves

. Eye protection as required -including full face shields and respirators when applicable. 
- Sanitation

- Clean change rooms with storage for street clothes.

- Separate storage facilities for work garments, protective clothing and equipment.

- clean and dirty change rooms separated partiallÿ bỷ a shower facility and partially by one-way doors.

- Contaminated protective clothing should be dry cleaned, laundered or disposed of.

- The presence, consumption or dispensing of food and beverages is to be discouraged in potential areas of exposure.

- Employees must wash hands thoroughly with soap or mild detergent and water before using toilet facilities or eating.

- Chemical solvents should not be used for removing materials from skin, as they may enhance dermal absorption.

- Any employee whose clothing or person becomes contaminated with hazardous substances should wash, shower, shampno and rhange, into clean work clothing promptly.

- Employees must be instructed in the potential hazards of their employment and good hygiene practices.

- Employers should institute a continuing education program.

- Work place and personnel monitoring shall be retained for the duration of the employment and at least. 30 years afterwards. 
(5) The Potential Hazards To Workers Exposed To Coal Liquefaction Products Through Routine Handling And Operations Will Be Greater Than Those of No. 6 Fuel Oil

Worker protection and hygiene programs will be needed to minimize worker contact and contamination with the product. It is expected that the NIOSH recommended coal gasification program will be adopted by those companies using coal liquefaction products.

Workers involved in loading, transport, unloading and storage of the direct coal liquefaction products will be potentially exposed to spills and leaks. The probable increased carcinogenicity of coal liquefaction products relative to No. 6 fuel oil previously discussed makes these operations relatively more hazardous with the direct liquefaction products.

- Cleanup and maintenance operations provide the greatest probability of exposure and hazard to workers.

- Six of the ten reported skin cancers at the Institute, West Virginia plant were found in maintenance workers.

- Dermail contact during maintenance operations is likely unless suitable protective equipment is worn, as workers will be exposed to "wetted" equipment parts.

- High boiling residues, rich in polycyclic aromatic hydrocarbons, are likely to be left in tank bottoms and in equipment to be repaired. 
- Sampling and analyses of the direct coal liquefaction products will involve direct exposure of the product to workers. This exposure will take place both in the plant and the laboratory from lengthy handling of small quantities of the product. Dermal contact and vapor exposure will be the routes of exposure.

- Based on compariscns of trace elements found in No: 6 fuel oil and coal liquefaction products Exhibit $B-15$, on the following page, and the analyses of the fuels used for the con Ed test burn, Exhibit B-7, the hazards of worker exposure to ashes and furnace deposits of direct coal liquefaction products should be less than or the same as those from exposure to ashes and deposits from No. 6 fuel oil.

- Trace elements analyzed are all under $39 \mathrm{ppm}$ in the Consolidated Edison SRC-II analyses.

- The trace element analysis done by the Electric Power Research Institute, Exhibit $B-15$, on the following page, shows only three elements with major differences.

- Vanadium and Nickel are greater in No. 6 fuel oil than in direct liquefaction. 


\section{EXHIBIT B-15 \\ Department of Energy \\ TRACE ELEMENTS FOUND IN PRODUCTS \\ FROM DIRECT LIQUEFACTION PROCESSES VS. \\ NO. 6 FUEL OIL}

\section{Trace Elements}

Sodium

Magnesium

Aluminum

Potassium

Titanium

Vanadium

Silicon

Lead

Iron

Nickel

Calcium
El Palito $\frac{\text { No. } 6 \text { Fuel oil }}{(\mathrm{ppm})}$

19

4

5

ND

78

275

3

2

6.4

59

14
Direct

Liquefaction

Products

(ppm)

$0.8-100$

$1-4$

$11-31$

$0.4-80.4$

80-130

$2.6-6.8$

$2-30$

$0-1$

$0-14$

1-21

8-49

Elements Not Detected

Mercury.

Cadmium

Silver

Zinc

Lithium

Phosphorous

Arsenic

Antimony

Bismuth

Molybdenum

Source: Electric Power Research Institute Report EPRI 361-1: Upgrading of Coal Liquids for Use as Power Generation Fuels, January 1976 


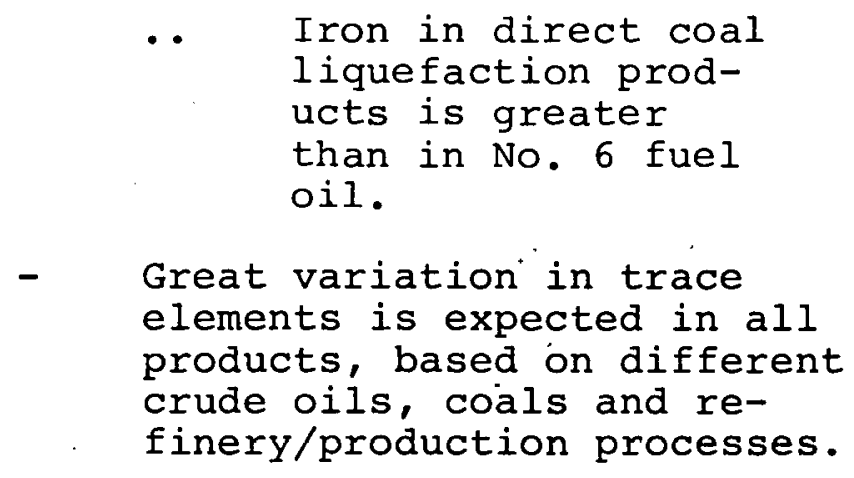

Chemical cleaning of fireside surfaces on boilers and auxiliary equipment is expected to present an increased hazard with coal liquefaction products as solvents used may promote skin penetration of the polycyclic aromatic hydrocarbons and also be carcinogenic promoters. Worker exposure to liquids and vapors during this process should be minimized.

(6) Episodal Events In The Plant Such As Accidents, Spills And Ruptures Can Be Handled Using Current Industry Practices

- The main hazards to workers from episodal events will be physical in nature.

$$
\begin{array}{ll}
- & \text { Fire } \\
\text { - } & \text { Explosion } \\
\text { - } & \text { Burns } \\
\text { - Injuries }
\end{array}
$$

- These immediate hazards are similar for both No. 6 fuel oil and direct liquefaction products. Additional precautions will probably not be necessary.

- Cleanup of the results of the episodal events will be somewhat more hazardous than from No. 6 fuel oil as described in the previous section. 
7. THE PRODUCTS OF DIRECT COAL LIQUEFACTION PROCESSES WILL PRESENT FEW AIR POLLUTION PROBLEMS

(1) Control of Routine Vapors And Leaks Will Be Needed

- The general properties of high boiling distillates with low vapor pressures are not expected to create wide range exposure problems to the general population.

- Workers will be exposed to routine vapors and leaks in the vicinity of equipment used in normal operations, inhalation exposure will probably be minimal due to the low vapor pressures.

- Good maintenance practices, as outlined in the coal gasification criteria document, should be implemented to ensure employee safety.

(2) Exposure To Workers And The General Population From Combustion Products Is Not Expected To Present A Health Threat Greater Than Already Exists With No. 6 Fuel Oil

- Limited combustion tests have shown no major problems associated with using coal liquefac. tion products for utility boilers even under variable load conditions.

- The test burn conducted at Consolidated Edison, in September 1978, demonstrated that "it was possible to substitute this higher nitrogen content SRC-II fuel for petroleum-derived fuel oil in a tangentiallyfired utility boiler over a range of normal operating loads without sacrificing boiler efficiency, while meeting all of the current emission standards for conventional petroleum fuel oil." Exhibit B-16, on the following page presents the results and significance of the test parameters. 
EXHAIT $B-16$ (1)

Department of Energy

SIGNIFICANCE OF EMISSIONS FROM COMBUSTION OF

SRC-II FUEL OIL COMPARED TO NO. 6 FUEL OIL

CONDUCTED AT CONSOLIDATED EDISON TEST

BURN--SEPTEMBER 1978

Parameter

Nitrogen oxide

Particulates

Polycyclic organics

Smoke tendency
Results

$\mathrm{NO}_{x}$ values for SRC-II

fuel oil are nominally

$70 \%$ higher than for

No. 6 fuel oil

Total mass emissions

for both fuels low.

SRC-II fuel oil nom-

inally lower than

cmissions from No. 6

fuel oil under all

operating conditions

with exception of

the full load baseline

test

Emissions with SRC-II

fuel oil were nominally

higher than No. 6 oil

levels. All analyges

lower than $6 \times 10^{-6}$

1b. $/ 10^{6}$ BTU $\underline{\text { Significance }}$

Increased $\mathrm{NO}_{x}$ emissions due to higher nitrogen content of SRC fuel oil. Absolute emissions will probably be within acceptable limits

Particulate emissions roughly equivalent to or lower than those obtained with No. 6 fuel oil
Emissions of polycyclic organic matter will be greater than with No. 6 fuel oil. However, absolute. concentrations are very low. More testing and analysis needed

Smoking tendencies of both fuels are similar occurred between 2 and 2.58 oxygen operation for both fuels 
EXHIBIT B-16(2)

Department of Energy

Parameter

Total hydrocarbon emissions (gaseous)

Sulfate emissions

\section{Results}

Emissions for SRC-II

and No. 6 fuel oil

both ranged from $1-2$

ppm with SRC-II occa-

sionally at 0.0

SO emissions for SRCII fuel oil were

measured at 0.3-0.9 ppm

No dala are provided

for No. 6 fuel oil

\section{Significance}

Gaseous total hydrocarbon emissions for both fuels similar

SO emissions for SRC-II fuel oil should be lower than for No: 6 fuel oil based on the chemical 'analysis. More testing and analysis necessary for confirmation

Source: Electric Power Research Institute, Combustion Demonstration of SRC-II Fuel Oil in a Tangentially Fired Boiler, FP-1029, May 1979 Booz, Allen \& Hamilton Inc. 
Chemical comparison of the direct coal liquefaction products supplied by DOE, Exhibit B-12, previously noted and additional analyses performed by Consolidation Edison, Exhibit A-7, provide a further basis for concluding that coal liquefaction products, under routine operating conditions should have emissions similar to or in some cases, even less than No. 6 fuel oil.

It is possible that sulfur and nitrogen oxide emission may be no different for direct coal liquefaction products and some No. 6-fuel oils. This possibility exists because of the variable nature of both product types--produced from various crude oils and coals.

- Sulfur emissions using coal liquefaction products may actually be lower than with No. 6 fuel oil.

.. Sulfur content of the No. 6 fuel oil used in the test burn was less than 0.3 percent, due to New York City statutes.

-. No. 6 fuel oil can be burned, in many areas with sulfur content approaching 2.2 percent.

- Nitrous oxides emissions, based on comparable product analyses, will be marginally higher for direct coal liquefaction products, but the overall effects may not be significant.

DOE nitrogen analysis of the direct coal liquefaction products, Exhibit B-12, indicates a range of $0.67-$ 0.86 percent. 
.. The nitrogen content of El Palito No. 6 Fuel Oil analyzed was 0.41 percent.

.. The nitrogen content of the SRC-II product used in the test burn varied from 0.87-1.16 percent.

.. The nitrogen content of Con Edison No. 6 Fuel Oil analyzed at $0.17-0.31$ percent.

Emissions of polycylic aromatic hydrocarbons from direct coal liquefaction products under routine operating conditions will be nominally higher than for No. 6 fuel o1l, however the absolute concentrations will be within acceptable limits for No. 6 fuel oil.

- Polycyclic aromatic hydrocarbons normally result from the combustion of No. 6 fuel oil.

- Many of the polyaromatic hydrocarbons in direct coal liquefaction products will be burned in the combustion process and converted to other combustion products; however some polyaromatic hydrocarbons are not destroyed until flame temperatures reach $33000 \mathrm{~F}$.

- Ut111t1es operate bollers at flame temperatures of approximately $3,2000^{\circ}-3,600^{\circ} \mathrm{F}$.

- The Con Edison test burn noted increased emissions of polycyclic organic hydrocarbons; however, the report noted that emissions were as (within acceptable limits) low as expected.

- Particulate emissions, except for the full load test at Con Edison, were actually lower for the SRC-II product than for No. 6 fuel oil. As a result of this test, no difference between the products is anticipated. 
(3) Episodal Events of Incomplete Combustion Could Present Problems And Further Testing Is Required For Scoping

Ashes, particulates and trace elements emitted from episodes of incomplete combustion should be similar in nature, due to the similar inorganic and trace elements analyses of products as can be seen in Exhibits $B-12$ and $B-13$, previously mentioned, and analyses of the products used during the Con Edison test burn, Exhibit B-7; therefore no increase in risk is anticipated. However, these tests are limited and do not fully test the question of incomplete combustion.

Emissions of polycylic aromatic hydrocarbons due to process upsets and the potential carcinogenic risk associated with them are not anticipated to be significantly greater with coal liquefaction products.

- The 3.59 to 5.47 percent oxygen content in SRC-II fuel oil, Exhibit B-8, will aid in the combustion of coal liquefaction boiler fuels when' excess air is limited to the burners-promoting combustion efficiency of the coal liquefaction fuel product.

- Volatilization of polycyclic aromatic hydrocarbons will occur both in coal liquefaction fuels and No. 6 fuel oil--the magnitude of volatiles emitted during incomplete combustion must be determined.

- Comparison of the two products under upset conditions must be conducted to provide definitive answers to this issue. 
- Increased particulate emissions and smoke may be produced by incomplete combustion of both No. 6 fuel oil and coal liquefaction products. Coal liquefaction products may produce more particulates under normal conditions--but further testing is necessary to assess this problem. 
8. THE PRIMARY CONCERN WITH WATER POLLUTION WILL BE RELATED TO SPILLS AND DISASTERS

(1) Routine Events Related To Water Pollution Will Require Control Measures Similar To Those Used For No. 6 Fuel oil

- Water pollution will come mainly from barges and tankers and will be related to small spills and leaks from normal handling.

- Operational discharges resulting from tanker operations are close to being eliminated. Methods developed by industry such as loadon-top, crude oil washing and pollution avoidance operating procedures are either recognized by international conventions, or have been enacted into law by the United States.

- Control measures used by Consolidated Edison in transporting SRC-II liquid product by barge can be used as a model for environmental and worker protection. The Con-Edison procedures are listed below:

- Barge steam cleaned and dried prior to use.

- Tank cars, barge and unloading line electrically grounded.

- Transfer lines from tank car to barge pressurized with nitrogen to check for leaks.

- Tank cars and lines flushed with nitrogen when empty to clear lines and avoid spills, when loading the barge.

- In unloading, regular pumping operations were used, without nitrogen purges. 
- In general, the highly aromatic. nature of the coal liquefaction products will have detrimental effects on marine organisms in areas where spills occur. If these marine organisms enter the food chain and reach people the possibility of toxic and carcinogenic systemic effects cannot be overlooked. Some toxic and carcinogenic compounds and elements can be bioconcentrated in organisms. It is not possible to ascertain the risk of this possibility relative to the same risk with No. 6 fuel oil.

(2) Episodal Events Such As Tanker Disasters Are Comparable To The Potential Hazards Created By Transporting Crude Oil

- Major disasters will bring qreat harm to the environment, similar to those previously experienced with tankers carrying crude oil.

- At present, the use of supertankers or extremely large tankers is not considered likely, owing to the size and probable locations of the coal liquefaction plants.

- On a smaller scale, the sinking of a large or small tanker carrying coal liquefaction products could have serious effects on the marine environment.

- The specific gravity of coal liquefaction products spans that of water. It is conceivable that the material will. float, weather, and sink, and therefore, poliute both the water surface and the bottom of the river, bay, or ocean.

- The large concentration of polycyclic aromatics and insolubles could have a toxic effect on marine organisms. Carcinogenicity from limited exposures is unpredictable.

- The polycyclic aromatics are generally high boilers and can be cleared up using conventional techniques.
- Containment
- Skimming
- Dispersants. 
9. GROUND CONTAMINATION IS NOT EXPECTED TO BECOME A MAJOR PROBLEM

(1) Products Are Routinely Transported And Stored In Closed Systems Such As Pipelines And Road And Rail Tankers

- Under routine conditions only small volume spills and leaks from transferring direct liquefaction products are expected to occur.

- These leaks should not present a major ground contamination hazard if cleaned up immediately.

- Containment of leaks is necessary.

- Sorbent materials should be used.

- Residue should be disposed of propcrly.

- Proper employee hygiene and work practices should be used to limit dermal exposure to the product.

(2) Episodal Events Such as Pipeline Breaks, Road and Railcar Tanker Accidents Can Be Handled Using Current Petroleum Industry Practices

The physical and chemical characteristics of coal liquefaction products permit them to be handled using conventional spill clean up techniques.

- Their specific gravity is similar to No. 6 fuel oil.

- Their viscosity is similar to No. 2 fuel oil.

- Their combustion characteristics are similar to No. 6 fuel oil. 
Three primary risks are involved with a pipeline break or road or rail tanker accident.

- explosion

- fire

- toxic effects from uncontrolled release of liquids.

- In order to limit the extent of hazard from coal liquefaction product the products must be removed with currently available techniques.

- Physical containment

.. blocking

.. trenching

- Removal and recovery

- Disposal

- Restoration of the area.

- Workers involved in the cleanup operation must be protected and yuud persundl hygiene practices will have to be carried out--this will be difficult in emergency situations and some worker/public contact is probable. 
10. IN SUMMARY, THE PRODUCTS OF DIRECT COAL LIQUEFACTION PROCESSES REPRESENT A SIIGHTLY GREATER ENVIRONMENTAL HAZARD THAN NO. 6 FUEL OIL. THE HAZARDS CAN BE CONTROLLED WITH ADEQUATE SAFEGUARDS.

The three coal liquefaction processes studied (H-Coal, SRC and EDS) are in developmental stages and epidemiological, analytical and quantitative toxiological data on their products are limited. Given the limited data available, our approach was to determine the potential hazards of direct coal liquefaction products by comparing chemical groupings at four levels of analyses; ultimate analysis; chemical groups; chemical compounds; and trace elements. Several key conclusions were reached:

Given that each of the three direct coal liquefaction processes start with a similar coal, the products produced would represent similar environmental hazards:

- Illinois No. 6 coal was used as the feedstock.

- The hazards of the three processes are similar and cannot be judged relative to each other, but only in relation to No. 6 fuel oil.

- The products of three direct coal liquefaction processes will contain a higher concentration of high boiling point components (in relation to No. 6 fuel oil). The higher boiling fractions represent higher concentrations of potentially environmentally hazardous materials, such as polycylic aromatic compounds, that are present in the products.

The primary areas of concern with direct coal liquefaction products are likely to be worker safety and health:

- There will be increased concentration of compounds that are toxic and/or carcinogenic (known or suspected) in nature

- Dermal contact will be the primary route of exposure. 
- Work practice controls should be more stringent than for No. 6 Fuel oil to minimize dermal exposure to products.

- Additional research is required to make preliminary judgments on the potential environmental hazards related to the burning of the fuel. possible end-user siting constraints may be required.

Exhibit B-17 on the following page presents a capsule summary of the relative environmental hazards of direct coal liguefaction products and their implications in relation to No. 6 Fuel oil.

Areas for further testing and development include:

- Biological studies on the coal liquefaction products.

- Biological studies on Number 6 Fuel Oil--to be used as a baseline for evaluating coal liquefaction products.

- Compositional analysis of products.

- Additional test burns of coal liquefaction products comparing results to Number 6 Fuel Oil data. These Lest burns should be pcrformed at:

- Normal conditions

- Upset ronditions--to determine the potential environmental efiect auring eptsudal events. 


\section{Environmental Area}

Worker safety \& Health

Air Pollution

Water Pollution

Ground Contamination

CAPSULE SUMMARY OF THE POTENTIAL HAZARDS OF DIRECT

COAL LIQUEFACTION PRODUCTS RELATIVE TO NO. 6 FUEL OIL

Routine Events

Potential Hazard Relative to No. 6 Fuel oil

iscussion

Controls would include good work practice and hygiene procedure

Current emission standards should be met-so $_{x}$ less, NO ${ }_{x}$ higher

\begin{tabular}{l} 
Episodal Events \\
Fotential Hazard \\
Felative to No. 6 \\
Fuel Oil \\
\hline
\end{tabular}

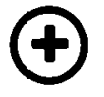

(2)

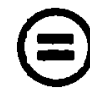

measures analogous

to No. 6 Fuel

will be required

Routine clean-up and disposal of spills and leaks similar to No. 6 Fuel oil

\section{Discussion}

Dermal exposure during clean-up operations will have to be controlled to minimize hazard

Possible increase in polycylic

aromatic compounds and particulates-more testing is needed

Tanker or barge accidents could have major environmental impact-similar to crude oil

Severe exposures must be controlled more stringently than No. 6 Fuel oil

\footnotetext{
(4) Greater Hazard Potential Than No. 6 Fuel 011

( Less Hazard Potential Than No. 6 Fuel oil

(Approximately Equal Hazard Potential To No. 6 Fuel oil
}

Source: Booz, Allen \& Hamilton Inc. 


\section{APPENDIX C}

SUPPLEMENTAL ANALYSIS AND DATA

\section{- ON ENVIRONMENTAL CHARACTERISTICS}


EXHIBIT $\mathrm{C}-1$

ANALYSIS OF ILLINOIS NO. 6 COAL

Proximate Analysis

Moisture
Ash
Volatile
Fixed carbon
Sulfur
Alkalies as Nąn
Higher heating value
$\quad$ mega joules/ḳg

As Received

Dry

Percent

Percent

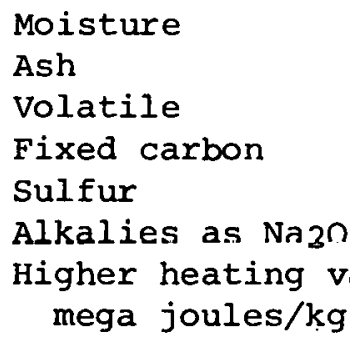

Moisture

Carbon

Hydrogen

Nitrogen

Chlorine

Sulfur

Ash

Oxygen
16.5

8.0

35.24

41.79

3.5

0.15

24.9

Ultimate Analysis

As Received
Percent

Dry

Percent

$$
16.5
$$

58.17

4.22

1.54

0.18

3.50

8.00

7.89

69.67

5.05

1.84

0.22

4.19

9.58

9.45

\section{Ash Analysis}

$\underline{\text { Percent }}$

Phosphorous, $\mathrm{P}_{2} \mathrm{O}_{5}$

0.11

Silica, $\mathrm{SiO}_{2}$

43.82

Ferric Oxide, $\mathrm{Fe}_{2} \mathrm{O}_{3}$

24.69

Alumina, $\mathrm{Al}_{2} \mathrm{O}_{3}$

17.19

0.88

4.96

Lime, CaO

1.02

Magnesia, Mgo

4.29

1.61

Potassium Oxide, $\mathrm{K}_{2} \mathrm{O}$

1.21

Sodium Oxide, Na2O

0.22

Source: EPA Report No. EPA-600/7-78-184B-Environmental Assessment Data Base for Coal Liquefaction Technology, September, 1978 
EXHIBIT C-2 (1)

TYPICAL TRACE ELEMENT COMPOSITION

OF ILLINOIS NO. 6 COAL

Element

Aluminum

Antimony

Arsenic

Barium

Beryllium

Boron

Bromine

Cadmium

Calcium

Cerium

Cesium

Chlorine

Chromium

Cobalt

Copper

Dysprosium

Europium

Fluorine

Gallium

Germanium

Hafnium

Indium

Iodine

Iron

Lanthanum

Lead

Lutetium

Magnesium

Manganese

Mercury

Molybdenum

Nickel

Phosphorous

Potassium

Rubidium

Samarium

Scandium

Selenium

Silicon

Silver

Sodium

Strontium

Tantalum
Symbol

Al

$\mathrm{Sb}$

As

$\mathrm{Ba}$

$\mathrm{Be}$

B

$\mathrm{Br}$

$\mathrm{Cd}$

$\mathrm{Ca}$

$\mathrm{Ce}$

Cs

$\mathrm{Cl}$

$\mathrm{Cr}$

Co

$\mathrm{Cu}$

Dy

Eu

$F$

$\mathrm{Ga}$

$\mathrm{Ge}$

Hf

In

I

Fe

La

$\mathrm{Pb}$

Lu

ivy

Mn

$\mathrm{Hg}$

$\mathrm{Mb}$

$\mathrm{Ni}$

P

$\mathrm{K}$

$\mathrm{Rb}$

$\mathrm{Sm}$

Sc

Sc

Si

Ag

$\mathrm{Na}$

$\mathrm{Sr}$

$\mathrm{Ta}$
Typical

Analysis

ppm

13,500

0.98

5.9

111.0

1.5

135.0

15.0

4.0

$7,690.0$

13.0

1.2

$1,600.0$

20.0

6.6

13.0

1.0

0.25

63.0

3.1

5.6

0.52

0.14

1.9

$18,600.0$

7.0

27.0

0.08

510.0

53.0

0.18

9.2

22.0

45.0

$1,700.0$

16.0

1.2

2.6

2.2

$26,800.0$

0.03

660.0

36.0

0.16 
Element

Thallium

Thorium

Tin

Terbium

Titanium

Tungsten

Uranium

Vanadium

Ytterbium

zinc

Zirconium
Symbol

T1

Th

Sn

$\mathrm{Tb}$

$\mathrm{Ti}$

W

$\mathrm{U}$

V

$\mathrm{Yb}$

$\mathrm{Zn}$

$\mathrm{Zr}$
Typical

Analysis

ppm

0.67

2.2

4. 7

0.17

700.0

0.70

1.6

33

0.54

420.0

52.0 
EXHIBIT $\quad$ - 3

(1)

DESCRIPTION OF HEALTH EFFECTS OF HAZARDOUS MATERIALS BY PHYSIOLOGICAL HAZARD CATEGORY

Effect

Acute toxicity

\section{Description}

The ability of a chemical or physical agent to indue a deleterious phisiological effect after a short exposure period-generally less than ${ }_{6} 6$ hours.

\section{Complicating Factors}

Linited knowledge of toxicities for humans. Rats, mice and rabbits generally used for tests. Giver: substances may vary in toxicity for each species. However, response are generally extrapolated directly to humans.

Dose relationship--generally acute toxicity is a curve linear function of a long dose. Therefore the greater the dose the more performed the toxicity.

Time relationship--generally the time of onset is related to the available dose. The effects of lower doses may never be observed in acure teszing.

There are individual differences in response to a toxic substance among members of a single species.

\section{Measurement}

ID $D_{50^{--t h e ~ m e d i a n ~ l e t h a l ~}}$ dose for a test population.

$\mathrm{LC}_{50^{--a}}$ lethal concentration of a substance in air or water, exposure to which, for a specified length of time, results in the death of $50 z$ of the experimental population.

Local tissue damage-skin and eye irritation generally conducted with rabbits or pigs. 


\section{Effect}

Biomagnification or bioaccumu-

lation

Carcinogenicity

\section{Description}

The accumulation of a xenobiotic in one or more tissues of a living organism.

\section{Complicating Factors}

Can result in tissue concentrations several thousand times greater than in ambient environment.

Is a normal process but can lead to pathologic responses.

More evident in organisms high on the food chain.

The expression of toxicity due to bicamplification can occur without warning since exposure to the hoxions agents is not evident.

The ability of a substance to cause cancer in an organism. Carcinogenicity has been defined by agencies as the ability to induce:

Frank cancer

Increased incidence of benign neoplasms

A decreased latency period for all neoplasms
Tests generally conducted on rats and mice by various routes of administration.

\section{Measurement}

Concentration in appropriate organ/species.

\author{
"Short-term" tests are \\ being developed based \\ on the relationship be- \\ tween mutagenicity and \\ carcinogenicity. These \\ are tests for potential. \\ damage to genetic material \\ which are conducted using \\ bacteria, yeast, and \\ mammalian cells in culture, \\ in-vivo mammalian tests are \\ aiso part of this battery.
}


Complicating Factors

Conclusions regarding carcinogenicity of a substance for humans are generally drawn from animal tests.

\section{EXHIBIT C-3 (3)}

\section{Measurement}

Exposure through various routes i.e. dermal, feeding or inhalation and at various concentrations to selected species and examining the tissues for neoplasms. Concentrations usually expressed as $\mathrm{mg} / \mathrm{kg}$ of body weight.

Some substances have been proven carcinogenic to humans on the basis of prior human exposure via the food chain or industrial resources.

\begin{abstract}
A dose response to carcinogenicity is more difficult to establish because of potentially long delays between exposure and onset of symptoms and/or the low incidence
\end{abstract} of cancers thus induced.

Genetic changes in germ cells may be transmitted to. the next generation.
The "Microbial Tests"--based on reverse mutations of sensitive mutant strains of bacteria and yeasts. The tests however, give false positives and negatives. 
Effect

Mutagenicity

(continued)

Teratogenicity

The ability of a substance to induce a developmental abnormality in an embryo or fetus.

\section{Complicating Factors}

Genetic changes in somatis cells may be transmitted to daughter cells.

Most cells or individuals that result from mutations do not live long enough to be recognized, those that do may be anatomically and/or functionally imparred.

A genetic change may not be expressed for several generations if the affected gene is recessive.

Abnormalities may be due to genetic changes (somatic mutatations) or to direct toxicity (injury) to maternal or fetal tissues.

\section{Measurement}

Tissue culture tests-based on forward mutations of mammalian cells in culture. Incidence of false positives less than bacterial tests.

Tests involve exposing pregnant laboratory animals during organogeneses to the substance and examining the offspring for anatomical abnormalities or increased intrauterine mortality.

Source: (1) United States Energy Research and pevelopment Administration Report FE-2495-6, Design and Implementation of an Environmental Monitoring Program for ERDA Fossil Fuel Activities--Task Summary Report III, Contract No. Ex-76-C-01-2495. February, 1977

(2) NIOSH Registry of Toxic Effects of Chemical substances--1976. 


\section{Component}

Inorganic compounds and elements
Healtr - Effect

Known carcinogens

Tumorigenic (tumor sausing) also possibly teratogenic

Super tozic - Lethal dose less than $5 \mathrm{mg} / \mathrm{kg}$

extrenely toxic - Lethal dose $5-53 \mathrm{mg} / \mathrm{kg}$

\section{EXHIBIT $\mathrm{C}-4$ (1)}

POTENTIAL HEALTH EFFECTS OF SOME COMPONENTS OF BOILER FUELS FROM DIRECT CCAL LIQUEFACTION PROCESSES AND NO. 6 FUEL OIL

Example

Diarsenic Trioxide $\mathrm{AS}_{4} \mathrm{O}_{6}$

Cobalt Oxide SoO

Cobalt sulfide Cos

Nickel Carbcnyl $\mathrm{Ni}(\mathrm{CO})_{4}$

Nickel oxide $\mathrm{NiO}_{2}$

Ammonia $\mathrm{NH}_{3}$

Silicon Dioxide $\mathrm{SiO}_{2}$

Thorium oxices Th(oxides)

Aluminum oxide $\mathrm{Al}_{2} \mathrm{O}_{3}$

Cobalt Co (elemental)

Gold Au

Lead Chromate $\mathrm{Pb} \mathrm{CrO}_{4}$

Mercury $\mathrm{Hg}$ (elemental)

Ozone $\mathrm{O}_{3}$

Thallium Tl (elemental)

Ytterbium Yb (elemental)

Diarsenic Trioxide $\mathrm{As}_{4} \mathrm{O}_{6}$

Cyanide CN

Hydrogen Cyanide $\mathrm{HCN}$

Diantimony $\mathrm{Tr}$ ioxide $\mathrm{Sb}_{4} \mathrm{O}_{6}$

Tricalcium Arsenate $\mathrm{Ca}_{3}\left(\mathrm{ASO}_{4}\right)_{2}$

Arsenic Vapor $\mathrm{As}_{4}$

Barium Carbonate $\mathrm{Ba} \mathrm{CO}_{3}$

Cadmium sulfice CdS

Iodine $I_{2}$

Thallium Th Salts

Sodium Vanadaie $\mathrm{NaVO}_{3}$ 


\section{Component}

Aliphatic compounds alkanes paraffins, alkenes, olefins, alkynes (triple bonded compounds)

Monocyclic compounds
Health - Effect

Very toxic - Lethal dose $50-500 \mathrm{mg} / \mathrm{kg}$

Moderately toxic

$0.5-5 \mathrm{gm} / \mathrm{kg}$

Tumorigenic, teratogenic

very toxic
Example

Boron Oxide $\mathrm{B}_{2} \mathrm{O}_{3}$

Calcium Sulfide CaS

Thiocyanide SCN

Chromates (M++) $\mathrm{CrO}_{4}$

Copper Sulfate CuSO

Gold Salts Au Salts

Lead Chromates $\mathrm{Pb} \mathrm{CrO}_{4}$

Silver Salts Ag Salts

Zinc Sulfide ZnS

Methyl chloride $\mathrm{CH}_{3} \mathrm{Cl}$

Methylene chlorid $\mathrm{CH}_{2} \mathrm{Cl}$

Chloroform $\mathrm{CHCl}_{3}$

Methyl Mercaptan $\mathrm{CH}_{2} \mathrm{SH}$

Ethyl Mercaptan $\mathrm{CH}_{3} \mathrm{CH}_{2} \mathrm{SH}$

Propane $\mathrm{CH}_{3} \mathrm{CH}_{2} \mathrm{CH}_{3}$

Pentane $\mathrm{CH}_{3} \mathrm{CH}_{2} \mathrm{CH}_{2} \mathrm{CH}_{2} \mathrm{CH}_{3}$

Chloroform $\mathrm{CHCl}_{3}$

Ethyl Sulfide $\left(\mathrm{CH}_{3} \mathrm{CH}_{2}\right)_{2} \mathrm{~S}$

Methyl-N-

Nitro-N-

Nitrosoquanidine $\mathrm{C}_{2} \mathrm{H}_{5} \mathrm{~N}_{5} \mathrm{O}_{3}$

U.S. Occupational Health Standards

regulate the following:

Benzene $\mathrm{C}_{6} \mathrm{H}_{6}$

4-dimethy1 Amino Azobenzene $\mathrm{C}_{14} \mathrm{H}_{15} \mathrm{~N}_{3}$

Phenol $\mathrm{C}_{6} \mathrm{H}_{5} \mathrm{OH}$

Biphenyl $\mathrm{C}_{12} \mathrm{H}_{10}$

Biphenyl Oxide $\mathrm{C}_{12} \mathrm{H}_{9} \mathrm{O}$

Cresol $\mathrm{C}_{6} \mathrm{H}_{4} \mathrm{OH}\left(\mathrm{CH}_{3}\right)$

Toluene $\mathrm{C}_{6} \mathrm{H}_{5}\left(\mathrm{CH}_{3}\right)$

Xylene $\mathrm{C}_{6} \mathrm{H}_{4}\left(\mathrm{CH}_{3}\right)_{2}$ 


\section{Component}

Health - Effect

Tumoriçenic agents

Very tcxic

Polycyclic aromatic

Hydrocarbons -- primarily

4,5 and 6 ring compounds

(also referred to as

polynuclear compounds)

\section{Example}

Benzene $\mathrm{C}_{6} \mathrm{H}_{6}$

4-Methyl Amino Azobenzene $\mathrm{C}_{14} \mathrm{H}_{15^{\mathrm{N}}}$

$1,3,5-\operatorname{tri}$ phenyl benzene $\mathrm{C}_{24} \mathrm{H}_{18}$

Phenol $\mathrm{C}_{6} \mathrm{H}_{5} \mathrm{OH}$

2,5 dimethyl phenol $\mathrm{C}_{6} \mathrm{H}_{3} \mathrm{OH}\left(\mathrm{CH}_{3}\right)_{2}$

2,6 dimethyl phenol $\mathrm{C}_{6} \mathrm{H}_{3} \mathrm{OH}\left(\mathrm{CH}_{3}\right)_{2}$

3,4 dimethyl phenol $\mathrm{C}_{6} \mathrm{H}_{3} \mathrm{H}\left(\mathrm{CH}_{3}\right)_{2}$

3,5 dimethyl phenol $\mathrm{C}_{6} \mathrm{H}_{3} \mathrm{OH}\left(\mathrm{CH}_{3}\right)_{2}$

O-Ethyl phenol $\mathrm{C}_{6} \mathrm{H}_{5}\left(\mathrm{CH}_{2} \mathrm{CH}_{3}\right)$

o-Cresola $\mathrm{C}_{6} \mathrm{H}_{4} \mathrm{OH}\left(\mathrm{CH}_{3}\right)$

M-Cresola $\mathrm{C}_{6} \mathrm{H}_{4} \mathrm{OH}\left(\mathrm{CH}_{3}\right)$

P-Cresola ${ }^{\mathrm{a}} \mathrm{C}_{6} \mathrm{H}_{4} \mathrm{OH}\left(\mathrm{CH}_{3}\right)$

Naphthalene $\mathrm{b}^{\mathrm{b}} \mathrm{C}_{10^{\mathrm{H}}} 8$ (more hazardous than

its methylated forms)

b-Naphthol $\mathrm{C}_{10} \mathrm{H}_{7} \mathrm{OH}$

Anthracene $\mathrm{C}_{14} \mathrm{H}_{10}$

Phenanthrene $\mathrm{C}_{14} \mathrm{H}_{10}$

Naphthalamine ${ }^{\mathrm{b}} \mathrm{C}_{1} \mathrm{H}_{7} \mathrm{NH}_{2}$

2-Naphthalamine ${ }^{b} \mathrm{C}_{10} \mathrm{H}_{7} \mathrm{NH}_{2}$

2-Acetyl Amino Fluorene $\mathrm{C}_{13} \mathrm{H}_{8}\left(\mathrm{CH}_{2} \mathrm{CO}_{2} \mathrm{H}\right) \quad \mathrm{NH}_{2}$

a. Carcinogenic with 7, 12-dimethyl berz(a) antiracene

b. U.S. occupational health standarcs regulate these compounds 
Carcinogenic NIOSH

Suspected/Known

\section{$\mathrm{x}$}

$\mathrm{X}$

$\mathrm{X}$

$\mathrm{X}$

$\mathrm{X}$

$\mathrm{X}$

$\mathrm{x}$

$\mathrm{x}$

$\mathrm{X}$

$\mathrm{x}$

$\mathrm{X}$

$x$

Tumor

\section{$\mathrm{X}$}

$\mathrm{X}$

$\mathrm{x}$

$\mathrm{X}$

$\mathrm{X}$

X $x$
Teratogenic

Naphthalene

Acenaphthene

Naphthalamine

2-Naphthalamine

Indole

Anthracene

9-Methyl Anthracene

9, 10-Dihydroanthracene

Benz (a) Anthracene

1,2 Benz Anthracene

Dibenz $(a, h)$ Anthracene

$1,2,5,6$ Dibenzo Anthracene

7,12-Dimethyl Benz (a)

\section{Anthracene}

Dibenzo $(a, i)$ Phenanthrene

Benzo (a) Phenanthrene

2-Methyl Chrysene

3-Methyl Chrysene

6-Methyl Chrysene

1,2-Benzo Fluorene

2-Acetyl Aminofluorene

Benzo (b) Fluoranthene

Benzo (j) Fluoranthene

Benzo (k) Fluoranthene

Pyrene

Benzo (a) Pyrene $(1,2)$

Benzo (e) Pyrene $(3,4)$

$0-$ Phenylene Pyrene

Dibenzo $(a, e)$ Pyrene

Dibenzo $(a, h)$ Pyrene

Dibenzo $(a, i)$ Pyrene

Indeno $(1,2,3-o d)$

Pyrene
$\mathrm{C}_{10} \mathrm{H}_{8}$

$\mathrm{C}_{12} \mathrm{H}_{12}$

$\mathrm{C}_{10} \mathrm{H}_{7} \mathrm{NH}_{2}$

$\mathrm{C}_{9} \mathrm{H}_{7} \mathrm{~N}$

$\mathrm{C}_{14}{ }^{\mathrm{H}} 10$

$\mathrm{C}_{14} \mathrm{H}_{9}\left(\mathrm{CH}_{3}\right)$

$\mathrm{C}_{14} \mathrm{H}_{8}(\mathrm{CH})_{2}$

$\mathrm{C}_{14} \mathrm{H}_{8}\left(\mathrm{C}_{4} \mathrm{H}_{4}\right)$

$\mathrm{C}_{14} \mathrm{H}_{8}\left(\mathrm{C}_{4} \mathrm{H}_{4}\right)$

$\mathrm{C}_{14} \mathrm{H}_{6}\left(\mathrm{C}_{4} \mathrm{H}_{4}\right)_{2}$

$\mathrm{C}_{14} \mathrm{H}_{6}\left(\mathrm{C}_{4} \mathrm{H}_{4}\right)_{2}$

$\mathrm{C}_{1 \cdot 4} \mathrm{H}_{6}\left(\mathrm{C}_{4} \mathrm{H}_{4}\right) \quad\left(\mathrm{CH}_{3}\right)_{2}$

$\mathrm{C}_{14} \mathrm{H}_{6}\left(\mathrm{C}_{4} \mathrm{H}_{4}\right)_{2}$

$\mathrm{C}_{14} \mathrm{H}_{8}\left(\mathrm{C}_{4} \mathrm{H}_{4}\right)$

$\mathrm{C}_{18} \mathrm{H}_{11}\left(\mathrm{CH}_{3}\right)$

$\mathrm{C}_{18} \mathrm{H}_{11}\left(\mathrm{CH}_{3}\right)$

$\mathrm{C}_{18} \mathrm{H}_{11}\left(\mathrm{CH}_{3}\right)$

$\mathrm{C}_{13} \mathrm{H}_{7}\left(\mathrm{C}_{4} \mathrm{H}_{4}\right)$

$\mathrm{C}_{13} \mathrm{H}_{8}\left(\mathrm{CH}_{2} \mathrm{CO}_{2} \mathrm{H}\right) \mathrm{NH}_{2}$

$\mathrm{C}_{16}^{+} \mathrm{H}_{8}\left(\mathrm{C}_{4} \mathrm{H}_{4}\right)$

$\mathrm{C}_{16} \mathrm{H}_{8}\left(\mathrm{C}_{4} \mathrm{H}_{4}\right)$

$\mathrm{C}_{16}{ }^{\mathrm{H}_{8}}\left(\mathrm{C}_{4} \mathrm{H}_{4}^{4}\right)$

$\mathrm{C}_{16}{ }^{\mathrm{H}} 10$

$\mathrm{C}_{16} \mathrm{H}_{8}\left(\mathrm{C}_{4} \mathrm{H}_{4}\right)$

$\mathrm{C}_{16} \mathrm{H}_{8}\left(\mathrm{C}_{4} \mathrm{H}_{4}\right)$

$\mathrm{C}_{16} \mathrm{H}_{6}$

$\mathrm{C}_{16} \mathrm{H}_{6}\left(\mathrm{C}_{4} \mathrm{H}_{4}\right)_{2}$

$\mathrm{C}_{16} \mathrm{H}_{6}\left(\mathrm{C}_{4} \mathrm{H}_{4}\right)_{2}$

$\mathrm{C}_{16} \mathrm{H}_{6}\left(\mathrm{C}_{4} \mathrm{H}_{4}\right)_{2}$

$\mathrm{C}_{22} \mathrm{H}_{12}$ 
Carcinogenic NIOSH

Suspected/known

Tumorigenic

Mutagenic

Teratogenic

$\mathrm{x}$

$\mathrm{x}$

$\mathrm{X}$
$\mathrm{X}$
$\mathrm{X}$

Hetrocyclic Compounds

Moderately toxic

Tumorigeric

suspected/Known

$\mathrm{X}$

$\mathrm{x}$

$x$

$x$

$\mathrm{x}$

$\mathrm{x}$

$\mathrm{x}$

$\mathrm{x}$
$3,4,9,10$-Dibenzo

$$
\text { Pyrere }
$$

Perylere

Cholanthrene

3-Methyl Cholanthrene

20-Methyl Cholanthrene

$\mathrm{C}_{16} \mathrm{H}_{6}\left(\mathrm{C}_{4} \mathrm{H}_{4}\right)_{2}$

$\mathrm{C}_{20} \mathrm{H}_{12}$

$\mathrm{C}_{20}{ }^{\mathrm{H}} 13$

$\mathrm{C}_{2} \mathrm{O}_{12}\left(\mathrm{CH}_{3}\right)$

$\mathrm{C}_{20} \mathrm{H}_{12}\left(\mathrm{CH}_{3}\right)$

Pyridene $b$

\section{Indole}

4-Nitrc Quinoline-N-Oxide

11 H-Benzo (a) Carbazole

Benz (c) Acridine

Dibenz $(a, h)$ Acridine
$\mathrm{C}_{9} \mathrm{H}_{7} \mathrm{~N}$ $\mathrm{C}_{9} \mathrm{H} 9 \mathrm{~N}\left(\mathrm{NO}_{3}\right)$ $\mathrm{C}_{12} \mathrm{H}_{7} \mathrm{~N}: \mathrm{NC}_{4} \mathrm{H}_{4}$ $\Sigma_{13^{\mathrm{N}} 7^{\mathrm{N}}\left(\mathrm{C}_{4} \mathrm{H}_{4}\right)}$ $\mathrm{Z}_{13} \mathrm{H}_{5} \mathrm{~N}\left(\mathrm{C}_{4} \mathrm{H}_{4}\right)_{2}$

Source: ERDA Design and implementatior. of an environmental monitoring frogram for ERDA fossil fuel activities FE2495- 6

NIOSH - Registry of Toxic Effects cf Chemical Substances 
EXHIBIT C- 5

SYNDROMES PRODUCED IN HUMANS BY

VARIOUS INORGÃNIC ELEMENTS

Element

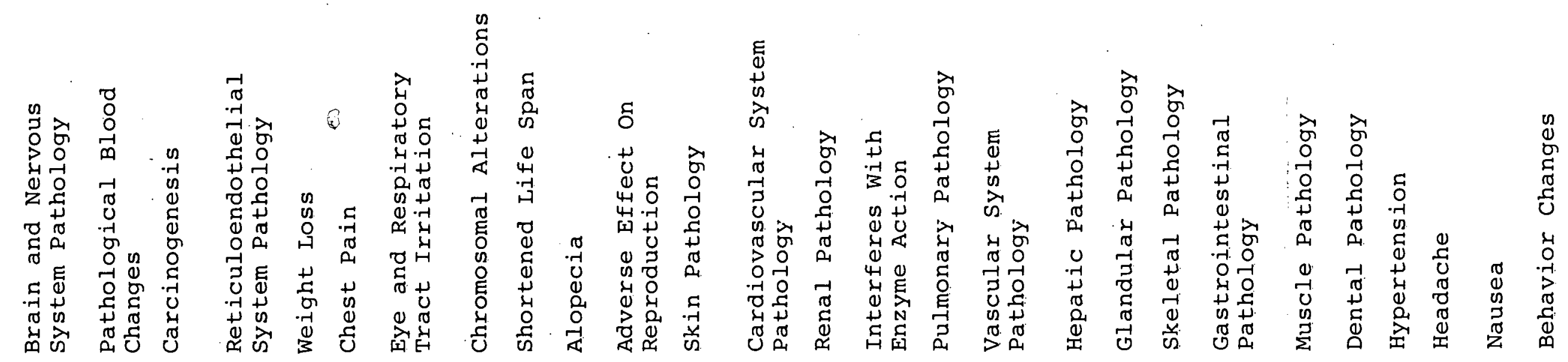

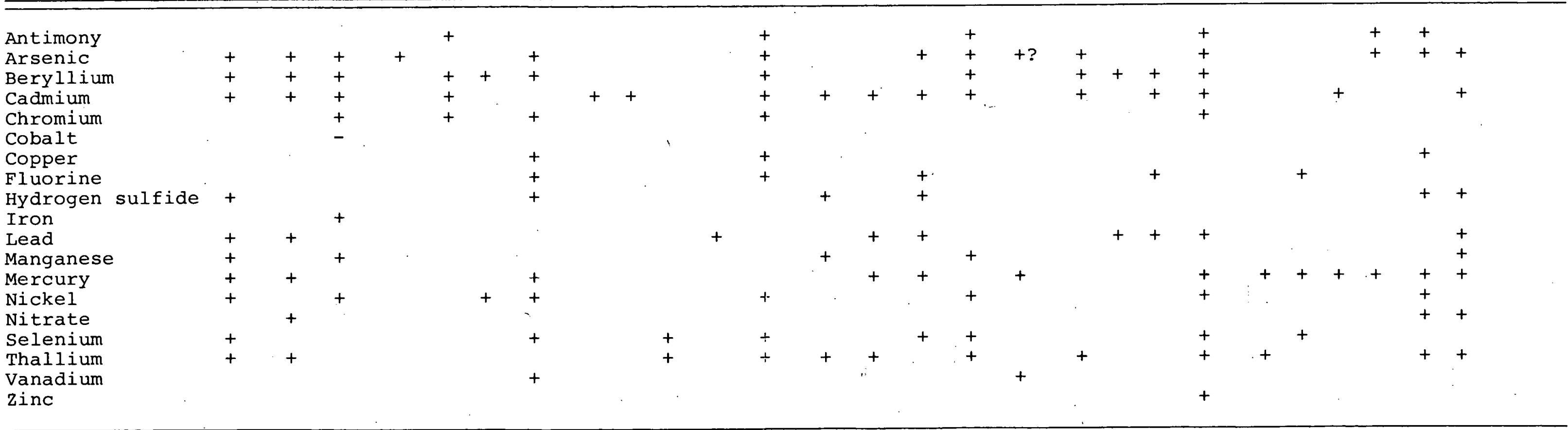




\author{
EXHIBIT C-6 (1) \\ SIGNIFICANCE OF ELEMENTS KNOWN TO CAUSE \\ PROBLEMS IN UTILITY BOILERS AND TURBINES
}

Properties

Ash

Vanadium

Sodium and Potassium

Calcium

Lead

Copper

Sulfur

Nitrogen

\section{Effect on Performance}

f.sh is the noncombustible material in a fuel and is limited to prevent excess deposition.

Vanadium can form low melting compounds, such as vanadium pentoxide, which melts at $1,275^{\circ} \mathrm{F}$ and, in the molten state, causes severe corrosion.

Sodium and potassium can combine with vanadium to form eutectics, which melt at temperatures as low as $1,0500^{\circ}$ and are also very corrosive.

Calcium is not harmful from a corrosion standpoint, but it can form hard-bonded deposits which are difficult to remove.

Lead deposits can be corrosive. Also, lead inhibits the beneficial effect of magnesium additives sometimes used. to control vanadium corrosion:

Copper is an oxidation catalyst which can cause poor thermal stability.

Sulfur combines with oxygen during combustion to form sulfur oxides. These combine with sodium or potassium present to form alkali sulfates which are corrosive. In many areas, the sulfur content is regulated as a control of sulfur oxide emissions in the exhaust gases.

Chemically bound nitrogen in the fuel will contribute to the total nitrogen oxide pollutants in the exhaust gases, adding to the nitrogen oxides formed from the direct combination of atmospheric nitrogen and oxygen in the gas turbine combustion reaction. 
Hydrogen

Low-hydrogen-content fuels are more difficult to burn without producing smoke because of incomplete combustion. Also, they tend to burn with a greater portion of the chemical energy in a fuel released as thermal radiation. This can cause overheating and a reduction in the life of combusion chamber parts. systems technical Data Book, contract no. EX-76-C-01-2286, May 1978 
EXHIBIT C-7

COMPARISON OF ANALYSES OF SRC-II FUEL AND NUMBER 6 FUEL OIL - BASED ON SRC-II TEST BURN AT CON EDISON SEPTEMBER 1978

Parameter

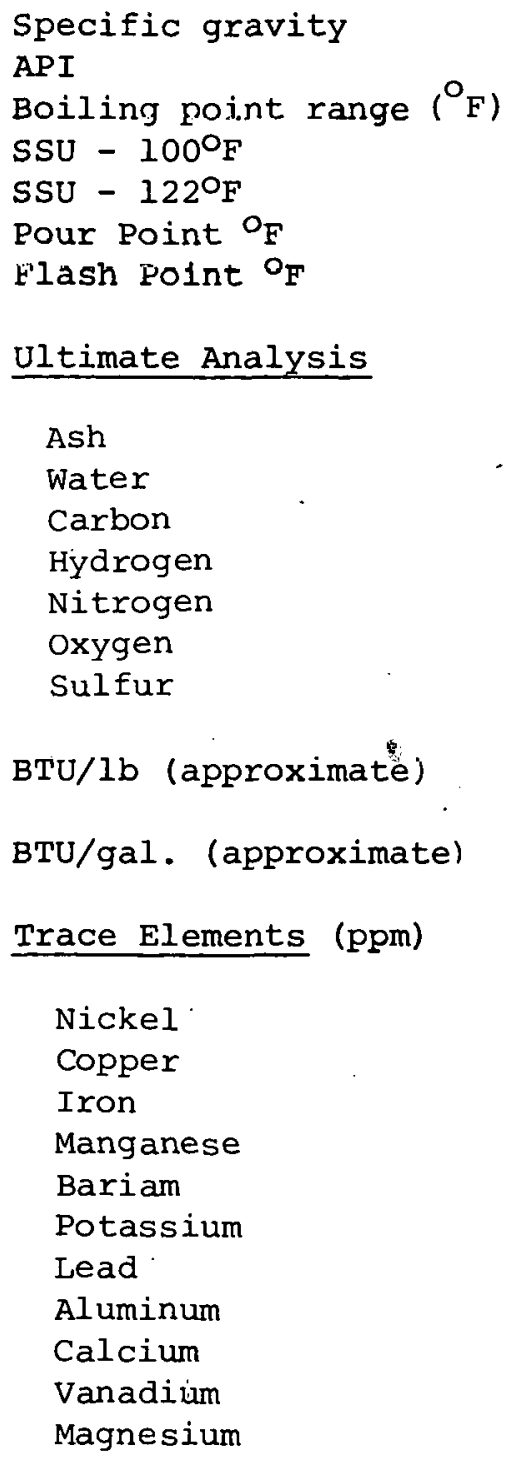

Ultimate Analysis

Ash

water

Carbon

Hydrogen

Nitrogen

oxygen

sulfur

BTU/1b (approximate)

BTU/gal. (approximate)

Trace Elements (ppm)
Nickel
Copper
Iron
Manganese
Bariam
Potassium
Lead
Aluminum
Calcium
Vanadium
Magnesium

Number 6
$0.8927-0.9194$
$22.0 \div 27.0$
315-618
$38.9-40.8$
$75-105$

$-$
SRC-II

$$
\begin{gathered}
0.9888-0.9937 \\
10.9-11.6 \\
350-850 \\
- \\
230-898 \\
-30+0-20 \\
140-180
\end{gathered}
$$

$$
\begin{array}{r}
0.01-0.02 \\
0.1-0.2^{a}
\end{array}
$$

$86.84-87.22$

$12.36-12.84$

$0.17-0.31$

$0.22-0.26$

19,000

145,000

$$
\begin{array}{r}
0.00-0.02 \\
0.2-0.3^{b}
\end{array}
$$

$84.55-86.88$

$8.80-9.01$

$0.87-1.16$

3. $59-5.47$

$0.13-0.26$

17,000

141,000

$18-39$
$0-1$
$3-5$
0
0
$1-2$
$0-15$
$0-3$
$2-7$
$2-12$
$3-5$

a. One sample $2.4 \%$ water out of 16 samples

b. One sample $50 \%$ water, one $2.5 \%$ out of 25 samples

Sources: Electric Power Research Institute, Booz, Allen \& Hamilton, Inc. 
EXHIBIT $\cdot \mathrm{C}-8$

SIMPLIFIED FEDERAL NEW SOURCE

PERFORMANCE STANDARDS FOR FOSSIL FUEL

FIRED STEAM GENERATORS (a)

Parameter

Particulate Matter

Sulfur Dioxide

Nitrogen Oxides $\underline{\text { Standards }}^{(b)}$

A. Not more than $0.18 \mathrm{~g} / 10^{6}$ calories

heat input $\left(0.101 \mathrm{~b} / 10^{6} \mathrm{BTU}\right)$

B. Not more than $20 \%$ opacity except that a maximum of $40 \%$ is permitted for not more than 2 minutes in any hnur

A. Not more than $1.4 \mathrm{~g} / 10^{6}$ calories heat input $\left(0.801 \mathrm{~b} / 10^{6} \mathrm{BTU}\right)$ derived from liquid fuel

B. Not more than $2.2 \mathrm{~g} / 10^{6}$ calories heat Input $\left(1.21 \mathrm{~b} / 10^{\circ} \mathrm{BTU}\right)$ derived from solid fuel

c. If a mixture of fuels is burned, the standard is calculated by the formula that proportions the heat input.

A. Not more than $1.4 \mathrm{~g} / 10^{6}$ calories ( $\left.0.80 \mathrm{1b} / 10^{6} \mathrm{BTU}\right)$ heat input derived from gaseous fuel

B. Not mure Lliall $0.54 \mathrm{~g} / 10^{6}$ calories (0.30 1b/10 $\mathrm{bTU}$ ) derived from 11quid fuel

C. Not more than $1.26 \mathrm{~g} / 10^{6}$ calories heat input (0.7 $\left.1 \mathrm{~h} / 10^{6} \mathrm{RTU}\right)$ derived from solid fuel

D. If a solid fuel contains more than 25\% coal refuse the standard does not apply.

E. Coal-derived liquids proposed regulation is $0.51 \mathrm{bs} / 10^{6} \mathrm{Btu}$.

a. Standard applies only to steam generators with a higher heating value heat input greater than 250 million $\mathrm{BTU} / \mathrm{hr}$.

b. Testing to be done by EPA approved methods

Source: U.S. Department of Energy Contract No. EX-76-C-01-2286

Preparation of a coal conversion systems technical data book. 
APPENDIX D

THE UTILIZATION OF METHANOL AS A BOILER FUEL 
THE UTILIZATION OF METHANOL AS A BOILER FUEL

The Department of Energy asked Booz, Allen \& Hamilton to assess the use of methanol as a boiler fuel in an effort to ascertain long-term economic advantages associated with such use. Booz, Allen reviewed existing literature on the subject and interviewed a cross section of utility and industrial sector representatives to gain an insight into marketplace acceptability of methanol used as a boiler fuel. A number of observations can be drawn from the industrial assessment, the most important of which is that methanol is perceived as an advantageous turbine fuel in combined-cycle operations rather than as a boiler fuel.

This chapter focuses on the use of methanol as a boiler fuel. The market outlook for methanol utilization is presented in four parts:

- Overview of methanol product specifications

- Review of research and development efforts addressing methanol utilization as a boiler fuel

- Industrial assessment of methanol utilization

- Barriers to market development.

1. BASED ON KNOWN SPECIFICATIONS, METHANOL HAS POTENTIAL APPLICATIONS AS A FUEL FOR POWER GENERATION IN STATIONARY BOILERS

Methanol is a synthetic fuel and chemical feedstock that can be manufactured from a variety of sources and applied to a variety of uses. Methanol can be extracted from natural plants or manufactured commercially from coal or natural gas. Most methanol manufactured currently is made by passing a synthesis gas containing hydrogen and carbon monoxide or carbon dioxide over a catalyst under pressure at elevated temperatures.

(1) The Physical and Chemical Properties of Methanol Indicate Methanol Would Be a Clean-Burning Fuel

Methanol contains very little sulfur and nitrogen, as indicated by Exhibit D-1, and consequently a cleaner stack emission is possible. Methanol combustion tests 
EXHIBIT D-1

Physical and Chemical Properties of Methanol

Storage and Handling Properties

Vapor pressure, psi at $100 F$

4.6

Specific gravity

0.793

Density, 1b/cu ft at $60 \mathrm{~F}$

49.7

Pour point (freezing point), F.

$-142$

Flash point (open cup), F

Solubility in water, $\frac{4}{0}$ at $68 \mathrm{~F}$

100

static charge

Toxicity

Moderate

Fuel Characteristics

Higher heating value, Btu/Ib

9760

Kinematic viscosity, cs at $77 \mathrm{~F}$

Volatility: $50 \%$, vaporized at this temperature, F

0.64

Stoichiometric mixture of fuel and air, lb air/lb methanol

6.5

Methanol $\left(\mathrm{CH}_{3} \mathrm{OH}\right)$, \%

Moisture, :

99.4

Higher alcohols, :

0.5

0.1

Ash, \%

Sulfur, :

$\mathrm{Nil}$

$\mathrm{Nil}$

Nitrogen, :

$\mathrm{Nil}$

Theoretical flame temperature, F

3490

Source: Gilbert Associates 
at Florida Power Corporation's Bayboro Station showed that nitrogen oxide emissions were 74 percent less than those from No. 2 fuel oil. Reasons cited were no nitgrogen content in methanol and a flame temperature lower than than for distillate which minimizes thermal $\mathrm{NO}_{\mathrm{x}}$ emissions.

(2) The Characteristics of Methanol Are Such that It Can Be Fired Directly in Steam Generators with Minimal Changes to the Equipment and with only a Slight Loss of Efficiency

A 1972 test at the Paterson Station of the New orleans Public Service Inc. was conducted on an oilfired boiler operating on chemical grade methanol. During the test, " $Y$ " shaped burner nozzles were used to enable complete combustion. The only other modification made was to install a centrifugal pump because the fuel oil pumps could not handle the low viscosity of methanol. These were the only changes made in the boiler and handling system.

During this 1972 test, it was found that the nethanol flame was less luminous than that of fuel oil or natural gas, and methanol had a lower flame temperature. This resulted in a three percent lower boiler efficiency than natural gas at equal loads. It should be noted, however, that this 1972 test took place long before the recent widespread interest in methanol utilization; and therefore, additional tests in boilers should be conducted to substantiate these early findings.

(3) Ilethanol's Heating Value Is Approximately Half That of No. 6 Residual Fuel Oil ihich Indicates Methanol: Punst Have an Attractive Delivered Price To Gain llarket Acceptance

The heating value of methanol is approximately $9,760 \mathrm{Btu} / \mathrm{lb}$. or $2.72 \mathrm{million} \mathrm{Btu} / \mathrm{barrel}$. To displace residual fuel oil in industrial or utility boilers, methanol must be priced competitively on a Btu equivalency basis with residual. Based on an extensive literature review and on discussions with industrial sector representatives, there are disparate prices indicated for methanol. Price disparities are influenced by the manufacturing process employed and the type of end use anticipated, whether it be for boiler fuels, turbine fuels, or as a gasoline blend. 
The marketplace representatives did not believe methanol could be brought in on a Btu-equivalent basis and indicated this would defer purchase decisions.

2. THERE ARE FEW RECENT BOILER FUEL TESTS USING METHANOL AND, CONSEQUENTLY, ONLY LIMITED TEST RESULTS ARE AVAILABILITY FOR REVIEW

(1) A Test Burn Using Methanol as a Boiler Fuel Was Conducted at the coen company, Burlingame, California in 1971

The test results were satisfactory from a combustion suitability point of view. NOx emissions were a quarter and a tenth of natural gas and No. 6 residual fuel oil, respectively.

(2) The Previously Mentioned Test at New Orleans Public Service Inc. Provides Some Guidance on Methanol Use, But the Research Should Be Updated

The methanol was handled in the same manner as other petroleum fuels used by the New Orleans Public Service Company. The test program consisted of a combustion comparison of methanol with natural gas and No. $b$ tuel oil. 'l'he results of the test were as follows :

Gross power generation from methanol is similar to No. 5 fuel oil and natural gas.

- Test results indicated a centrifugal pump would be needed in parallel to existing pumps due to methanol's low viscosity.

Stack emissions were monitored during the test burn." The following results were obtained:

- No particulates were observed.

- NO N $_{x}$ emissions in the fuel gas were less than those from natural gas and much less than $\mathrm{NO}_{\mathrm{x}}$ emissions, from fuel oil combustion.

- There were low levels of aldehydes, organic acids, and hydrocarbons in the fuel gas. 
- Carbon monoxide concentrations from the methanol burn test were less than those observed for the fuel oil and natural gas tests, which may be indicative of more complete combustion.

- There were no $\mathrm{SO}_{2}$ emissions reported.

The foregoing tests indicate that methanol has combustion characteristics suitable for boiler use. However, the tests are somewhat dated. Interviews conducted by Booz, Allen with boiler manufacturers, industrial, and utility representatives supported methanol's combustion suitability but indicated largescale tests should be conducted to determine longterm technical suitability and economic implications. Interviewees indicated methanol utilization depended primarily on its economic advantages and on emission regulations governing boiler fuel combustion.

(3) Transporation and Handling Requirements for Methanol Do Not Seem To Be Plarket Entry Barriers

Research conducted in support of the tests described earlier indicate methanol can be pipelined, shipped, transferred, and stored in a manner now provided for other products that are currently available in the marketplace. Methanol should be able to be stored and shipped in conventional carbon steel tanks and vessels. Floating roof-type storage tanks would be needed to reduce evaporation losses and pollution. This latter factor owes to methanol's volatility.

Researrh data indicate that a separate fuel handling system would be necessary when methanol is used as a supplement to fuel oil. This would include independent storage, piping, and pumps to segregate methanol from a fuel oil system. These requirements are dictated primarily by the solvent nature of methanol and methanol's low flash point $\left(52^{\circ} \mathrm{F}\right)$. There is no specialized equipment necessary-only segregated facilities of the same variety used for fuel oil utilization.

Additional observations about methanol handling can be drawn from previous research efforts:

- The research and development efforts to date indicate that where a boiler is equipped 


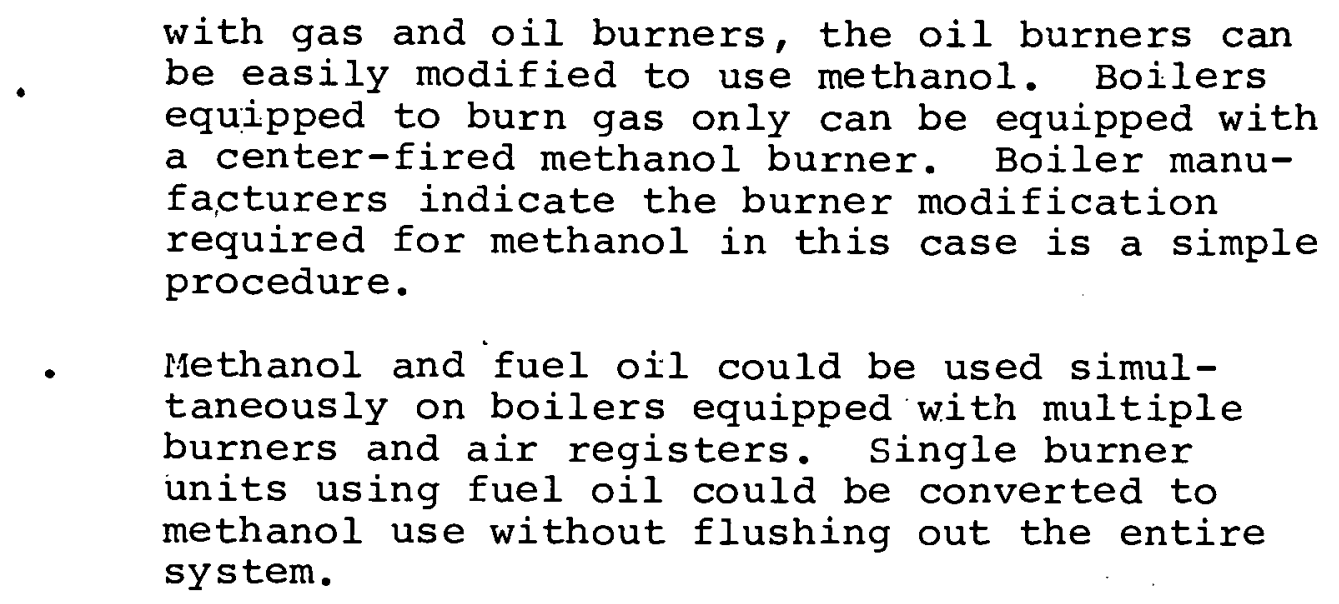

3. AN INDUSTRIAL ASSESSMENT OF METHANOL UTILIZATION INDICATES THAT UTILITIES AND INDUSTRIAL BOILER OWNERS MAY BE INTERESTED IN USING METHANOL AS A BOILER FUEL IF IIETHANOL BECOIE ECONOMICALLY ATTRACTIVE

Interviews with utilities, boiler manufacturers, and boiler owners indicate that the boiler fuel market is receptive to the utilization of methanol as a fuel. The interviews yielded several consistent findings about the use of methanol. The interviews also shed some light on potential barriers that may restrain the large-scale entry of methanol into the boiler fuel market.

(1). Methanol Appears To Be Technically Suitable As a Boller Fuel; However, Lack of Current Information and Test Burn Data May Pose a Near-Term Market Barrier To Industrial and Utility Úse

Companies are aware of methanol as a potential fuel but expressed concern over technical fit and combustion characteristics. This is primarily due to a lack of recent information and test burn data. They perceive methanol as a clean-burning fuel and believe that little maintenance would be required for its use. Companies are well aware of the minimum environmental risks commonly associated with methanol utilization. 
(2) Reliability of Supply at a Competitive Price Is of Paramount Importance for liethanol To Introduce and Sustain Itself as a Viable Replacement for Other Available Boiler Fuels

The major findings of the industrial assessment are that methanol is a technically suitable fuel but price is not economically attractive. Fuel specifications as to type and composition impact boiler selection and design. Fuel combustion characteristics are the major concern of burner manufacturers. Buyer behavior will be influenced by availability of supply and costs that are competitive with alternative fuels in terms of price, handling costs, and efficiency. Burners can be designed to handie almost any combustible fuel, and potential buyers do not perceive retrofitting to be a market barrier.

Industry is interested in obtaining menthanol for combuation tecting. The industrial marketplare is familiar with the tests, conducted to date, but boiler manufacturers are interested in more tests to confirm market suitability.

4. THE MAJOR MARKET BARRIER FOR LARGE-SCALE METHANOL UTILIZATION AS A BOILER FUEL IS PRICE

(1) Price Is Not Perceived As Being Economically Attractive

lethanol is perceived as being at a 'competitive cost disadvantage relative to other boiler fuels available in the marketplace. As such, the economics of methanol will have to improve before the market. becomes responsive to large-scale utilization of methanol as a boiler fuel.

Mdditional Research Should Be Undertaken Th Determine Long-Term Economic Advantages of Using Methanol as a Boiler Fuel

Recent research addresses methanol as a turbine fuel in combined-cycle operations. To adequately answer the question about the economic advantages of using methanol as a boiler fuel, large-scale test burns conducted for a long period need to be undertaken. 
APPENDIX E

ORGANIZATIONS INTERVIEWED 


\section{Boiler Manufacturers}

American Boiler Manufacturers Așsociation. $A B C O$ Industries, Inc. AERCO International, Inc. ALPHA Steam Generator Corporation

Applied Engineering Company

Babcock and Wilcox Company

Bryan Steam Boiler Company

Brasch Manı̣facturing Co., Inc.

Combustion Engineering, Inc.

Deltak Corporation

Enerex Incorporated

E-Tech, Inc.

Foster Wheeler Energy Corporation

John Zinc, Inc.

Ncbraska Boiler Company

Ocean Shore Iron Works, Inc.

Fower Flame, Inc.

Process Combustion Company

Ray Burner Company.

Riley Stoker Corporation

The Coen Company

\section{Boiler Owners}

Council of Industrial Boiler Owners

Fairfax, Virginia

Dow Chemical Company

Freeport, Texas

Dupont

Wilmington, Delaware

General Electric Company

Schenectady, New York

Monsanto Company

st. Louis, Missouri 
Utility Companies and Organizations

American Electric Power

Baltimore Gas and Electric Co.

Boston Edison

Consolidated Edison

Edison Electric Institute

Electric Power Research Institute

Florida Power \& Lighting Co.

Houston Lighting \& Power Co.

Long Island Lighting Co.

Middle South Services

Northeast utilities

Potomac Electric Power co.

Philadelphia Electric C̀o.

Southern California Edison

Tennessee Valley Authority

Investment Community

Dillon Reed

Morgan Stanley

Salomon Brothers

Government Organizations

Defense Supply Agency

Department of Energy

Environmental Protection Agency

National Institute of Occupational Safety and Health

New York Energy Research and Development Authority

occupational Safety and Health Administration

Coal Liquefaction Process Technology Companies

Ashland Oil, Inc.

Carter Oil Company

Dynalectron

Gulf Mineral Resources Company

Mobil Oil Corporation 
Non-Government Organizations

American P'etroleum Institute

Washington, D. C.

Enviro Control, Inc.

Bethesda, Maryland

Hittman Associates

Columbia, Maryland

Oak Ridge National Laboratories

Oak Ridge, Tennessee

Pacific Northwest Tahoratories

Richmond, Washington

Suntech Corporation

Marcus Hook, Pennsylvania

University of Arizona

Tuscon, Arizona

University of Cincinnati

Cincinnati, Ohio

\section{Labor Unions}

AFI-CIO

Pipeline Companies

Amoco Pipeline Company

Chicago, Illinois

Colonial Pipeline Company

Houston, Texas

Plateau Pipeline Company

Alburqueque, New Mexico

Texas Eastern Transmission Company

Houston, Texas

Williams Brothers Pipeline' Company

Tuls.a, Oklahoma 
-Oil Companies

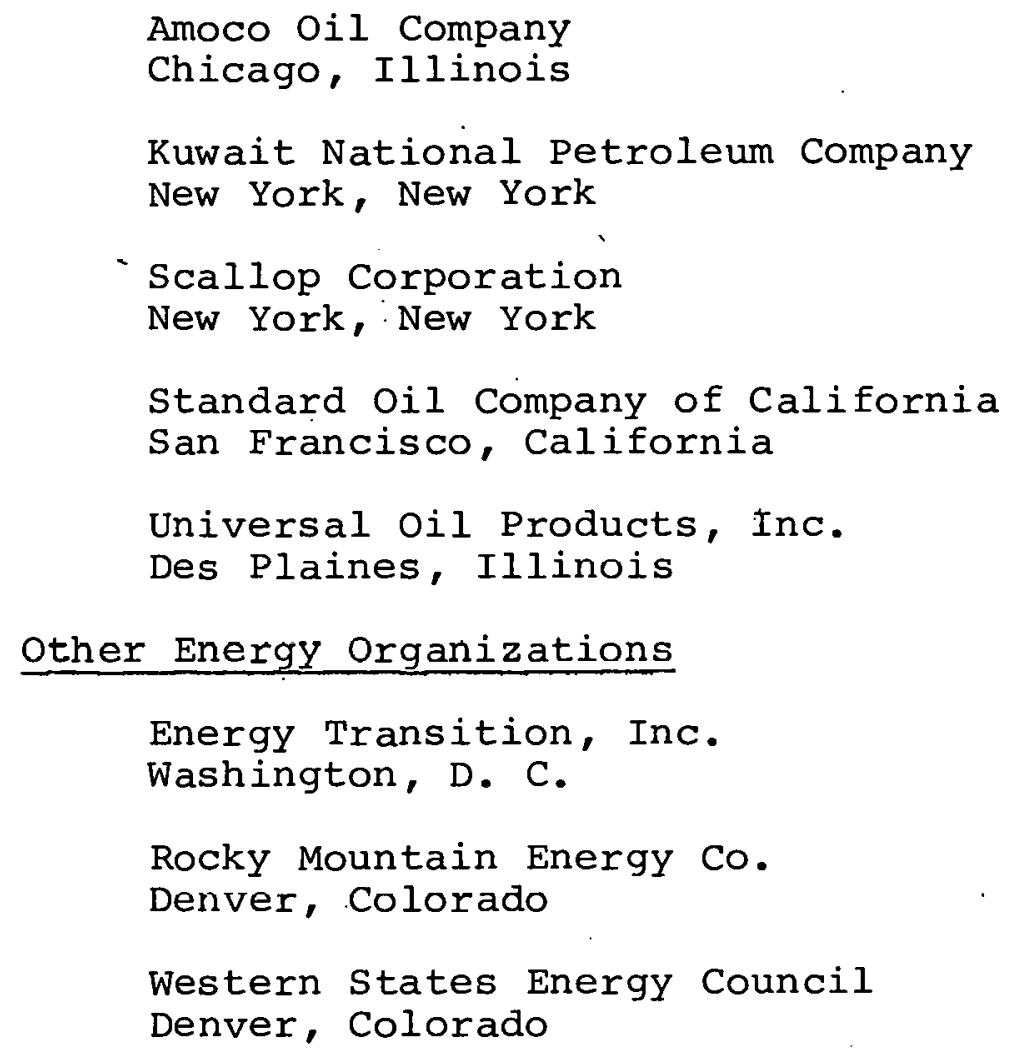

$\underline{\text { Railroads }}$

Burlington Northern Chessie Systems Norfolk and Western Southern Pacific

Architectural and Engineering Firms

Dravo Corp.

Florida Power Corp.

Fluor Corp.

KVB Associates

Stone and Webster 
MARKETING BIBLIOGRAPHY 
"Burning Tomorrow's Fuels - Liquids: Coal-Derived Oil,". Power (February 1979), pp. 510-513.

"Burning Tomorrow's Fuels - Liquids: Methanol," Power (February 1979), pp. 514-515.

"Burning Tomorrow's Fuels - Liquids: Pyrolytic Oil," Power (February 1979), pp. 515-516.

"Can SRC Find a Home:" Electric Light \& Power 56(1) (January $1978($, p. 26.

"Coal Liquids Said Feasible for Existing Oil-Fired Plants." Electric Light \& Power 56(7) (July 1978), p. 49.

"Exxon: Searching for Another Game That Equals Oil in Size." Business Week (July 16, 1979), pp. 80-82.

"Oil From Coal: It Could Be a Gusher by the 1990s." Chemical Week (November 8, 1979), pp. 36.37.

"Sasol Technology Draws DOE Interest: Task Force on Coal Liquids Is set Up." The Energy Daily 7(79) (April 26, 1979), p. 1 .

"Scaling Up Coal Liquids." EPRI Journal 3(7) (September 1978), pp. 6-12.

"Synthoil Process for Converting Coal to Non-Polluting Fuel Oil." Energy Technology Handbook, edited by Douglas M. Considine, pp. 1-269-271.

Alsid, Snowden and Associates. Solvent Refined Coal (SRC) Process: Environmental Program. Volume III Pilot Plant Development Work. Part 5 Environmental Program for the Period 1/1/72-6/30/77. R\&D Report No. 53. Interim Report No. 25. March 1978 .

Badger Plants, Inc. Conceptual Design of a Coal To Methanol Commercial Plant, volume III: Environmental.

Bakers, A., and M.D. Teper. "Coal Liquefaction: International Energy Agency Perspective." Energy Technology VI, edited by R.F. Hill, pp. 639-656.

Balzhiser, Richard E., "Energy Options to the Year 2000." Chemical Engineering (January 3, 1977), pp. 73-90. 
Battelle Columbus Laboratories. Liquefaction and Chemical Refining of Coal. Program Report. Columbus Ohio: July 1974.

Becker, C.D., W.G. Woodfield, and J.A. Strand. Solvent Refined Coal Studies: Effects and Characterization of Treated Solvent Refined Coal Effluent. Progress Report. PNL-2608, JulY 1978 .

Booz, Allen \& Hamilton. Safety Analysis of the Rail Transportation of Hazardous Materials. Bethesda, Maryland: 1978.

Brodsky, Arthur R. "Compulsory Synfuel Plan Mulled." Energy User News $3(11)$ (March 13, 1978), pp. 1, 18.

Covell, Russel B., and Michael J. Hargrove. Power Cycle Evaluations of the C-F Cnal Gasification Process. Paper presented at American Power Conference, Chicago, Illinois: April 23-25, 1979 .

Drake, D.D., and H.L. Falkenberry. "Kentucky's Coal-Based Chemical/Energy Park." In Energy Technology VI, edited by R.F. Hill, pp. 55-69.

Duhl, R.W. Methanol: A Boiler Fuel Alternative. Paper presented at the Eighth Annual Meeting of the American Institute of Chemical Engineers, Bostón, Massachusetts: September $7-10,1975$.

Duhl, R.W., and J.W. Boyland. Use of Methanol as a Boiler Fuel. Paper presented at IV-A Symposium, Swedish Academy of Engineering Sciences, Stockholm, March 23, 1976.

Department of Energy. Environmental Readiness Document: Coal Liquefaction Commercialization Phase III Planning. Report DOE/ERD-0015, September 1978.

Department of Energy Task Force. Commercialization Strategy. Report for Coal Liquefaction. Report TID-28846 (Draft). 1978.

Exxon Research \& Engineering Co. EDS Coal Liquefaction Process Development: Phase IIIA. Final Technical Progress Report. February 1978.

Fluor Engineers and Constructors, Inc. Conceptual Design for Advanced Coal Liquefaction Commercial Plant. Technical Report FE-2251-51. April 1978. 
Foster Wheeler Energy Corp. Clean Distillate Fuels Pilot Plant Conceptual study. Final Report EPRI-ÄF-622. April 1978.

Gardner, S.A. "Methanol: Coal-Derived Energy for the 1980s." Coal Mining \& Processing 15(5) (May 1978), pp. $60-61,72,78$.

Gellender, M. "Coal Will Underpin Chemical Industry." Canadian Chemical Processing 62 (8) (August 1978), pp. 21$23,27$.

Gilman, H.H., and Norman Stewart. Filtration Equipment Development for Coal Liquids. Final Report, AF852.

Givens, E.N., et al. "Hydroprocess Solvent Refined Coal," Hydrocarbon Processing (November 1978), pp. 195-202.

Gouraud, Jackson. "Department of Energy's Approach to Commercialization." In Energy Technology VI, edited by R.F. Hill, pp. 36-39.

Hayes, Earl T. "Energy Resources Available to the United States, 1985 to 2000." Science 203 (January 19, 1979), pp. 233-239.

Hill, G.R. Technical and Economic Status of coal and Oil Shale Conversion. Paper presented at Water Acquisition for Mineral Development Conference, Tucson, Arizona, March $16,1978$.

Hittman Associates, Inc. Environmental Assessment of Coal Liquefaction. Annual Report. February 1978.

Hittman Associates, Inc. . Standards of Practice for the Solvent Refined Coal Liquefaction Process. Final Report. HIT.714. June 1978.

Hoertz, Charles D. "Coal Liquefaction - Fuels and Petrochemicals: The H-Coal Project." In Energy Technology VI, edited by R.F. Hill. pp. 70-75.

Honig, E.M., and S.A. Hathaway. Application of Modern Coal Technologies to Military Facilities, Volume I: Summary of Findings. Interim Report CERL-IR-E-130 (V.I). May 1978. 
International Research \& Technology Corp. Materials-ProcessProduct Analysis of Coal Process Technology, Volume I.

Final Report HCP/T2027-01. September 1978.

KVB, Inc. Combustion Demonstration of SRC-II Fuel oil in a Tangentially Fired Boiler. Report EPRI-FP-1029. Palo AIto, California: May 1979.

Kolling, G., I. Romey, and E. Wolowski. "Current German Developments in Coal Liquefaction Technology." In Energy Technology VI, edilted by R.F. Hill, pp. 657-663.

Lee, B.S. "Several Synfuel Options Now Look Highly Promising." Energy User News 3(10) (March 1978), pp. 22-23.

McKimmey, Michael L. "Regional Conversion to Coal." In Energy Technology VI, edited by R.F. Hill. pp. 562-583, April 1979.

McNeese, L.E., Royes Salmon, and H.D. Cochran, Jr. "Recent Developments in Coal Liquefaction in the United States." In Energy Technology VI, edited by R.F. Hill, pp. 664-679. April 1979.

Miller, Earle C. "New Coal Technologies Attracting Attention." Consulting Engineer 50(4) (April 1978), pp. 96-100.

Mobil Research and Development Corporation. Upgrading of Coal Liquids for Use as Power Generation Fuels. Report EPRI AF-444. October 1977.

Mobil Research and Development Corporation. Upgrading of Coal Liquids for Use as Power Generation Fuels. Report EPRI AF-873. December 1978 .

Mobil Research and Development Corp. Upgrading of Coal Liquids for Use as Power Generation Fuels. EPRI Report 361-1. - Paulsboro, New Jersey: January 1976.

Mobil Research and Development Corporation and Westinghouse Research Laboratories. An Investigation of the Utilization of Coal-Derived Liquid Fuels in a Combustion Turbine Engine. Report EPRI AF-873, Appendix A. December 1978 .

Nelson, W. J. "Question on Technology: Coal-Conversion Plants Cost 5 .Times Refineries." The Oil and Gas Journal (April 16, 1979), p. 91 . 
Nelson, W.L. "Question on Technology: What Are Prices of Gas and Oil From Coal." The Oil and Gas Journal (April 23, $1979)$, p. 67.

O'Hara, J.B., et al. "Feedstocks From Coal: How? When?" Hydrocarbon Processing (November 1978), pp. 117-121.

Pearson, E. "Trigeneration Concept See Commercial by 1985." Energy User News 3 (37) (September 11, 1978), p. 13.

Ralph M. Parsons Co. Coal Liquefaction Process Research, Mobil M-Gasoline Process. R\&D Interim Report No. 1. June 1978 .

Reddy, G. N. Advanced Processes for Generation of Electric Power: Solvent Refining of Coal and Combined Cycle Plants. Paper presented at Fifth National Conference on Energy \& the Environment, Cincinnati, Ohio, October 31, 1977.

Reddy, G.N. Commercialization of Coal-Based Combined Cycle Plants. Paper presented at the 7lst Air Pollution Control Association Meeting, Houston, Texas, June 25, 1978.

Rogers, K.A., et al. Comparison of Coal Liquefaction Processes. Final Report on Task 006. April 1978.

Sen, C.T. "Sullie Comments on Coal Convcraion Options:" Energy Topics (June 19, 1978).

Sherman, R.J., R.H. Quig, and W. Fuchs. "Tri-Generation: A Concept which Integrates Gasification with Co-Generation." Aware 90 (March 1978), pp. 9-15.

Spencer, Dwain F. "Coal Liquefaction Incentives." EPRI Journal (September 1978), pp. 2-3.

Spencer, Dwain, and Oliver Gildersleeve. "Market Potential for New Coal Technologies." EPRI Journal (May 1978), pp. 19-26.

Stewart, J.T., and M.G. Klett. Coal Conversion for Feedstock and Fuel. American Society of Mechanical Engineers. Paper 78-PET-I7. 1978.

Stewart, J.T., and M.G. Klett. "Converting Coal to Liquid/ Gasious Fuels." Mechanical Engineering (June 1979), pp.34-41. 
Stone \& Webster Engineering Corp. "Coal-Derived Liquids: A Continuing study." Electrical World (July 1, 1978), pp. 52-54.

Swabb, L.E., Jr. "Liquid Fuels From Coal: From R\&D to an Industry." Science 199 (February 10, 1978), pp. 619-622.

'l'alty, John T. "Ässessing Coal Conversion Processes." Environmental Science \& Technology 12(8) (August 1978), pp. 890-894.

United States Senate Committee on Energy and Natural-Resources. Synthetic Fuels From Coal: Status and Outlook of Coal Gasification and Liquefaction, Publication No. 96-17. June 1979.

Wieber, P.R., and A.P. Sikri. "Development of In Situ Processes for Energy and Fuelg From Coals." Mining Engineering 30 (5) (May 1978), pp. 557-565.

Wise, D.L., and D.C. Augenstein. In Situ Liquefaction of Coal." pp. 173-195.

"Engineering Analysis of In Situ 2(3) (1978), 
ENVIRONMENTAL BIBLIOGRAPHY 
"A New U.S. Push for Coal to Oil Technology," Business Week, November 7, 1977 pp. 84D-84F.

Aczel et. al, Chemical Properties of Snythoil Products and Feeds, MERC-8007-1. Performed by Exxon Research and Engineering Co. for U.S. Dept. of Energy, Contract No. EY-76-C21-8007, February 1977.

Anbar, Michael, Molecular Profile Analysis of Coal Products, EPRI AF-390. Prepared by Stanford Research Institute for EPRI, February 1977.

Andrew, F. D. et. al., Developmental Toxicity of Solvent Refined Coal-Related Hydrocarbons, Battelle Memorial Institute, Pacific Northwest Laboratories, Richland Wa., supported by Dept. of Energy Contract No. EY-76-C-06-1830.

1977 Annual Book of ASTM Standards, American Society for Testing and Materials, Philadelphia, Pa. 1977.

Arcos, J. C. et. al., Chemical Induction of Cancer, Vol. I, II A, and II B, New York: Academic Press, 1968.

Armstrong, G. T., Hydrocarbons For Fuel--75 Years of Materials Research at NBS, PB-253 665, National Bureau of Standards, May 1976.

Ayer, F. A. and M. F. Massoglia, Symposium Proceedings: Environmental Aspects of Fuel Conversion Technology III, EPA-600/7-78-063. Performed by Research Triangle Institute for EPA/IERL, April 1978.

Baldwin, R. M., "The Solvent Refined Coal Process," Chemical Engineering Progress 71, No. 4 (April 1975).

"Balzhiser R. E., "Energy Options to the Year 2000," Chemical Engineering 84: 73-90 (January 3, 1977).

Bendoraitis, J. G. et. al., Upgrading of Coal Liquids for Use as Power Generation Fuels, EPRI 361-1, Mobil Research and Development Corp., January 1976.

Braunstein, H. M. et. al, Environmental, Health and Control Aspects of Coal Conversion; An Information Overview Vol. I ORNL/EIS-94. Prepared by Oak Ridge National Laboratories for ERDA, Contract No. W-7405-eng-26, April 1977.

Braunstein, H. M. et. al, Environmental, Health, and Control Aspects of Coal Conversion: An Information Overview Vol. TI. Prepared by Oak Ridge National Laboratory for ERDA, Contract No. W-7405-eng-26, April 1977. 
Budden, K. G. and S. S. Patel, Air Emissions from Combustion of Solvent Refined Coal. Performed by Hittman Associates Inc. for EPA/IERI, Contract No. 68-02-2162, January 1979.

Burton, F. G., Disposition of Process Solvent from Solvent Refined Coal in Tissues of the Rat After Oral Dosing, Battelle Memorial Institute, Pacific Northwest Laboratories, Richland, Wa. Supported by Dept. of Energy, Contract No. EY-76-C-06-1830.

Chakrabarti, C. L. et. al., Chemistry of Petroleum Processing and Extraction, MSS Information Corp., New York, N.Y.

Chow, J. K. and Stanbridge, D. W., Screening Evaluation: Synthetic Coal Liquid Fuels Manufacture, EPRI-AF-523, Ralph M. Parson Co., Pasadena, Cal., Auqust 1977.

Christensen, H. E. et. al, Registry of Toxic Effects of Chemical Substances, HEW/ NIOSH, 1976.

Christensen, H. E. et. al, suspected Carcinogens--A Subfile of the Registry of Toxic Effects of Chemical Substances, HEW/NIOSH, 1976.

Cichorz, R. S., Carcinogenicity of Residual Fuel oils by Nonbiological Laboratory Methods, RFP-2436. Prepared by Rockwell International for ERDA, Contract No. $E(29-2)-3533$, April 1976.

Curl, H. and K. O'Donnell, Chemical and Physical Properties of Refined Petroleum Products, ERL MESA-17, National Oceanic and Atmospheric Administration, October 1977.

Cushman, R. M. et. a.., The Toxicity of 35 Trace Elemenls in Coal to Freshwater Biota-A Data Base with Automated Retrieval Capabilities, ORNL/TM-5793. Performed by Oak Ridge National Laboratories for ERDA, Contract No. W-7405-eng-26, June 1977.

Davis, A. et. al, The Influence of the Properties of Coals on Their Conversion into Clean Fuels, Energy Sources, Vol. 3. No. 1, New York: Crane, Russak 1976.

Demeter, J. J. et. al. "Combustion of Coal-Oil slurry in a 100-HP Firetube Boiler," Combustion, (April 1978) pp. 31-37. 
Dorset, P. et. al., Advanced Fossil Fuel and the Environment: An Executive Report, EPA-600/9-7-013. Performed by stanford Research Institute for EPA/OEMI, Contract No. 68-01-2940,

Dry, M.E., "Advances, in Fischer-Tropsch Chemistry," Industrial Engineering Chemistry, Vol. 15, No. 4 (1976) pp. 282-286.

Duhl, R.W. "Methanol as Boiler Fuel," Chemical Engineering Progress, Vol. 72 (July 1976) pp. 75-76.

Duhamel, A. P. Mutagenicity and Carcinogenicity Data on Crude Materials from Several Fossil Fuel Technologies, Memorandum U.S. Dept. of Energy, EV-443 January 12, 1979 .

Eckmann, J. M. et. al, Parametric studies of COM Combustion Presented at lst International Symposium Coal-0il Mixture Combustion by Pittsburgh Energy Research Center, May 1978.

EDS Coal Liquefaction Process Development; Phase III A, Quarterly Technical Progress Report; January 1-March 31 , 1977, FE-2353-14. Performed by Exxon Research and Engineering Co., December 1977.

Environmental Development Plan--Coal Liquefaction Program FY 1977, DOE/EDP-0012 D.0.E., March 1978.

Environmental Readiness Document-Coal Liquefaction, Commercialization Phase III Planning, DOE/ERD-0015, U.S. Department of Energy, September 1978.

Environmental Review of Synthetic Fuels, EPA/IERL, Research Triangle Park, N.C. Vol. 2, No. 1, January 1979.

Environmental Review of Synthetic Fuels, EPA/IERL, Research Triangle Park, N.C. Vol. 2 No. 2 May 1979.

Epler, J. I. et. al., "Analytical and Biological Analyses of Test Materials from the Synthetic Fuel Technologies I. Mutagenicity of Crude oils Determined by the Salmonella Typhimurium/Microsmal/Activation System," Mutation Research, Vol. 57 (1978) pp. 265-276, Elsevier/North-Holland Biomedical Press.

Epler, J. L. et. al., Energy-Related Pollutants in the Environment, conf-780121-2 Oak Ridge National Laboratories, Tenn. 1978 . 
Farcasia, M. "Asphaltols--Keys to Coal Iiquefaction," Chemtech, November 1977, pp. 680-688.

Feretti, E. J. "Coal Liquefaction Gains Prominence," Coal Mining and Processing Vol. 13, 1976 pp. 64-74.

Forrester, R. C. et. al., Polycyclic Aromatic Hydrocarbons and the Oak Ridge National Laboratory's Experimental Coal Program Minimizing the Hazards, conf-770210-5, Oak Ridge National Laboratories, Tenn., 1977.

Fossil Energy Research and Development Program of the U.S. Department of Energy, DOE/ET-0013 (78), March 1978.

Frazier, M. M. et. al., Use of Mammalian Cell Culture Techniques for Determining the Toxic and Carcinogenic Potential of Complex Urganic Mixtures, Battelle Memorial Institute, Pacific Northwest Laboratories, Richland Wa. Supported by D.O.E. under Contract No. EY-76-C-06-1830.

Gleason, Gosselin, Hodge \& Smith, 1969, Clinical Technology of Commercial Products, 3rd ed. Baltimore: Williams \& wilkins.

Grosshandler, W. L., The Furnace Combustion and Radiation Characteristics of Methanol and a Methanol/Coal Slurry, LBL-5947. Prepared by Lawrence Berkeley Laboratory, University of California/Berkeley for ERDA, Contract No. w-7405-eng-48, January 1977.

Guthrie, V. B., 1960, Petroleum Products Handbook, New York: MCGraw-H111.

Hagen, D. L., Methanol as a Fuel: A Review with Bibliography, Society of Automotive Engineers, 770792, September 1977.

Hagen, D. L., Methanol: Its Synthesis, Use as a Fuel, Economics and Hazards, NP-21727, ERDA, December 1976.

Hàkansson Ho and Av Oernelöv, Petroleum and Petrochemicals IVL-B346 Swedish Water and Air Pollution Research Laboratory, January 1977 .

Heuper, W. C., "Experimental Carcinogenic Studies on Hydrogenated Coal Oils--I. Bergius Oils," Industrial Medicine and Surgery, Vol. 25. February 1956 pp. 51-55.

Heuper, W. C., "Experimental Carcinogenic Studies on Hydrogenated Coal Oils--II. Fischer-Tropsch Oils," Industrial Medicine and Surgery, October 1956 pp. 459-462. 
Hoertz, C. $\mathrm{D}_{\mathbb{B}}$, Coal Liquefaction--Fuels and Petrochemicals, The $\mathrm{H}$-Coal ${ }^{\circledR}$ Project, Ashland Oil, Inc. Paper presented to ET-6.

Holmes, S. A. et. al., Characterization of Coal Liquids

Derived from the H-Coal Process-BERC/RI-76110, Bartlesville Energy Research Center, November 1976.

Hopkins, H. T., et. al., SRC Site-Specific Pollutant Evaluation; Vol. I Discussion, EPA-600/7-78-223a. Performed by Hillman Associates Inc. for EPA/IERL, Contract No. 68-02-2162, November 1978 .

Hopkins, H. T., et. al., SRC Site-Specific Pollutant Evaulation; Vol. 2. Appendices, EPA-600/7/78-223b. Performed by Hittman Associates for EPA/IERL, Contract No. 68-02-2162, November 1978 .

Husting, E. L. et. al., Occupational Health Issues and Fossil Energy Development, TR-13500-1. Prepared by Flow Resources Corporation for D.O.E., March 1978.

Karn, F. S. and F. R. Brown, Aging studies of the Synthoil Product Part II: Effects of Time, Temperature, Atmosphere ER.C,TPR-76,2, Pittsburgh Encrgy Reeearoh Conter, scptombcr 1976 .

Kawahara, F. K. and Y. Y. Yang, "Systems Chemical Analysis of Petroleum Pollutants," Analytical Chemistry, Vol 48, No. 4, April 1976.

Kirk-Othmer, 1963 Encyclopedia of Chemical Technology, 2nd ed. New York: wiley.

Koralek, C. S., and S. S. Patel, Environmental Assessment Data Base for Coal Liquefaction Technology: Volume ISystems for Fourteen Liquefaction Processes, EPA-600/78-184a. Prepared by Hittman Associates, Inc. for EPA/IERL, August 1978.

Leavitt, C. et. al., Environmental Assessment of coal and Oil-Firing in a Controlied Industrial Boiler, EPA-600/7-78164a. Performed by TRW Inc. for EPA/IERL, August 1978.

Leavitt, C. et. al.., Environmental Assessment of Coal and Oil-Firing in a Concrolled Industrial Boiler; Vol. II Comparative Assessment, EPA-600/7-78-164b. Performed by TRW Inc. for EPA/IERL, contract No. 68-02-2613. 
Leavitt, C. et. al., Environmental Assessment of Coal and Oil-Firing in a Controlled Industrial Boiler, Volume III. Comprehensive Assessment and Appendices, EPA-600/7-78-164 C. Prepared by TRW Inc., for EPA/IERL, August 1978.

Leichter, I. et. al., Air Quality Impacts Using SRC Versus Conventional Coal in Power Plants, EPA-600/7-78-203. Prepared by Hittman Associates, Inc. for EPA/IERL Contract No. 68-02-2162, August 1978 .

Lett,. R. G. et. al., Screening for Hazardous Elements and Compounds in Process Streams of the One-Half Ton Per Day Synthoil Process Development Unit, PERC/RI-77/12, Pittsburgh Energy Research Center, October 1977.

Lloyd, E.A., Commercialization Readiness of Coal Liquefaction, U.S. Department of Energy Task Force Report, June 12, 1978.

Locklin, D. et. al., Power Plant Utilization of Coal, PB289 475, Battelle Memorial Institute, September 1974.

Lowry, H. H., 1945 Chemistry of Coal Utilization New York: Wiley.

Mahlum, D. D., and F. D. Andrew, Acute and Subchronic Toxicity of Solvent Refined Coal-Related Hydrocarbons Battelle Pacific Northwest Laboratories, Richland, Wa. supported by D.O.E. under Contract No. EY-76-C-06-1830.

Mottson, J. S., Classification of Oils By the Application of Fattern Recognition Techniques to Infrared Spectra CG, D-6-77. Prepared for DOT/U.S.C.G., March 1976 .

McCann, C. R. et. al., "Combustion of Pulverized, SolventRefined Coal," Journal of Engineering for Power, Vol. 99, No. 3 (July 1977) pp. 305-308.

McCann, C. R. et. al., Combustion Test Facility-Coal-oil Mixtures and Liquids, $100 \mathrm{HP}$ Unit-Firetube Boiler, SRC-II Combustion Tests, Pittsburgh Energy Research Center, D.O.E.

McCarthy, L. T. et. al., Standard Dispersant Effectiveness and Toxicity Tests, EPA-R2-73-201. Performed by Edison water Quality Research Laboratory for EPA/NERC MaY 1973.

McNamee, G. P. et. al., Process Engineering Evaluations of Alternative Coal Liquefaction Concepts, EPRI-AF-741 (Vol. I.), Ralph M. Parsons Co. Pasadena, Cal., April 1978. 
Morris, S. C. et. al., Coal Conversion Technologies: Some Health and Environmental Effects, New York: Brookhaven National Laboratory, February 1979.

Muccini, G. A. and R. A. Culp, A Workshop on the Analytical Needs of the Future as Applied to Coal Iiquefaction, PB272-077. Performed by Ashland Oil, Inc. for National Science Foundation, August 1974.

Neavel, R. C., "Liquefaction of Coal in Hydrogen-Donor and Non-Donor Vehicles," Fuel, Vol..55, July 1976 pp. 237-242.

U'Hara, J. B., "Materials Challenges of Coal Liquefaction," Chemical Engineering, April 11, 1977 pp. 147-154.

Oldham, R. G. et. al., Assessment, Selection and Development of Procedures for Determining the Environmental Acceptability of Synthetic Fuel plants Based on Coal-Basic Report and Appendix 1, FE-1795-3 (PT. 1). Performed by Radian Corp. for U.S. Dept., of Energy, Contract No. EX-76-C-01-1795, May 1977 .

Oldham, R. G. and R. G. Wetherold, Assessment, Selection and Development of Procedures for Determining the Environmental Acceptability of Synthetic Fuel Plants Based on Coal; Appendix 2, FE-1795-3 (PT. 2). Performed by Radian Corp. for U.S. Dept. of Energy, Contract No. EX-76-C-011795, May 1977.

Palmer, H. B. and J. M. Beer, 1974 Combustion Technology: Some Modern Developments, New York/London: Academic Press.

Pancilov, R. J.. Compositional Data on API Réference Oils Usea in Biological Studies; A \#2 Fuel Oil, A Bunker C, Kuwait Crude Oil, and South Louisiana Crude Oil. Performed by Esso Research and Engineering Company for the American Petroleum Institute, Report No. AID. 1BA. 74, February 1974.

Parker, C. L. and D. I. Dykstra, Environmental Assessment Data Base for Coal Liquefaction Technology: Volume IISyllthoil, H-Coal and Exxon Donor Solvent Processes, EPA600/7-78-184b. Prepared by Hittman Associates, Inc. for EPA/IERL, Contract No. 68-02-2162, September 1978 .

Pelroy, R. A. and Peterson, M. R., Comparative Mutagenesis of Solvent Refined Coal and Shale Oil Samples from Pilot Plant Operations, Battelle Memorial Institute, Pacific Northwest Laboratories, Richland, Wa. supported by DOE Contract No. EY-76-C-06-1830. 
Perry, J. H. et. al., 1963 Perry's Chemical Engineers Handbook 4 th ed. New York: McGraw-Hill.

Piper, B. F. et. al., Combustion Demonstration of SRC-II Fuel oil in a Tangentially Fired Boiler, FP-1029.. Prepared by KVB Inc. for Electric Power Research Institute, May 1979 .

Preparation of a. Coal Conversion Systems Technical Data Book, FE-2286-16. Prepared by Institute of Gas Technology for U.S. D.O.E. Contract No. EX-76-C-01-2286, January 1978.

Preparation of a Coal Conversion Systems Technical Data Book. FE-2286-28 prepared by Institute of Gas Technology for U.S. D.O.E. Contract No. EX-76-C-01-2286, May 1978.

Price, B, H. et. al, , A Preliminary Review of Current Research Activities Bearing on Carcinogenic Effects of Coal Liquefaction, working paper, Mitre Corporation for D.O.E. WP-79W00084, March 1979.

Proceedings 1979 Oil Spill Conference (Prevention, Behavior, Control, Cleanup), sponsored by API, EPA and USCG, March 19-22, 1979, Los Angeles, Calif., API publication 4308 .

Retcofsky, H. L: et. al., "Determination of Aromaticities of Coal Derivatives by Nuclear Magnetic Resonance Spectrometry and the Brown-Ladner Equation," Analytical Chemistry Vol. 49, No. 4, April 1977 pp. 585-588.

Rolan, R. G., Design and Implementation of an Environmental Monitoring Program for ERDA Fossil Fuel Facilities, Task Summary Report III, FE-2495-6. Prepared by Dalton-DaltonLittle-Newport, for ERDA, Contract No. EX-76-C-01-2495, February 1977.

Sampling strategy and Characterization of Potential Emissions From Synfuel production, Conf 760602, Symposium/Workshop sponsored by ERDA, June 1976.

Sax, V. I., Dangerous Properties of Industrial Materials 4 th ed. Litton Educational Publishing, Inc., New York: 1975, Van Nostrand Reinhold.

Schabron, J. F., et, al., "Separation of Hydroaromatics and Polycyclic Aromatic Hydrocarbons and Determination of Tetralin and Naphthalene in Coal-Derived Solvents," Analytical Chemistry, Vol. 49, No. 14, December 1977 pp. 22 $\overline{53-2260 .}$ 
Schiller, J. E., "Composition of Coal Liquefaction Products," Hydrocarbon Processing, Vol. 56, January 1977 pp. 147-152.

Schiller, J. E., "Nitrogen Compounds in Coal Derived Liquids." Analytical Chemistry, Vol. 49, No. 14, December 1977 pp. 2292-2294.

Schwager, I. and J. F. Yen, "Coal-Liquefaction Products from Major Demonstration Processes," Fuel, 1978 Vol. 57, February pp. 100-104.

Schwartz, L. et. al., Occupational Diseases of the Skin, 2nd e.., tuea and Febiger, Philadelphia, Penn. 1947.

Schwieger, R. G. "Burning Tomorrow's Fuels," Power, Vol. 123, No. 2, February 1979 pp. 5.1 - 5.24.

Sexton, R. J. et. al., "The Hazards to Health in the Hydrogenation of Coal," Archives of Environmental Health, Vol. I (1960) pp. 15/181-65/231.

Sharkey, A. G. Jr., Mass Spectrometric Analysis of Process Streams for Coal-Derived Fuels, New York: Raven Press, 1976.

Shultz, H. et. al., The Distribution of Some Trace Elements in the One-Half Ton Per Day Synthoil Process Development Unit, PERC/RI-7712, Pittsburgh Energy Research Center, February 1977 .

Solvent Refined Coal (SRC) Process Development of a Process For Producing an Ashless, Low-Sulfur Fuel From Coal Vol. III-Pilot Plant Development Work Part 3-startup and Operation of the Plant, FE-496-T13. Prepared by the Pittsburgh and Midway Coal Mining Co. for ERDA, Contract No. E(49-18)496 .

Solvent Refined Coal Biostudies, Pacific Northwest Laboratories, Battelle Memorial Institute, Richmond, Washington.

Solvent Refined Coal (SRC) Process: Health Programs, FE/496115 EX-76-C-01-496. Prepared by the Pittsburg and Midway Coal Mining Co. for U.S. Department of Energy, January 1978.

Solvent Refined Coal (SRC) Process: Trace Elements FE/496T17, EX-76-C-01-496. Prepared by the Pittsburgh and Midway Coal Mining Co. for U.S. Department of Energy, April 1978. 
Spectral Studies of Coal-Derived Liquids PERC/RI-77/14, Pittsburgh Energy Research Center, November 1977.

Squiles, A. M., "Chemicals from Coal," Science, Vol. 191 February 20, 1976) pp. 689-699.

Stinson, S. C., "Methanol Primed for Future Energy Role," Chemical and Engineering News, (April 2, 1979) pp. 28-30.

Stone, L. K., "Emissions From Coal Conversion Processes," Chemical Engineering Progress, Vol. 71 (December 1976) pp. 52-57.

Summary of NIOSH Recommendations for Occupational Health Standards, HEW/NIOSH, October 1978 .

Turner, P. P, et. al.. Advanced oil Processing/Utilization Environmental Engineering: EPA Program Status Report EPA-600/7-78-077, EPA, Office of Research and Development IERL, May 1978 .

Tyndall, M. F. et. al., Environmental Assessment for Residual Oil Utilization--Second Annual Report, EPA-60/7-78-175. performed by catalytic, Inc, for EPA/IERL, Contract No. 68$02-2155$.

U.S. Dept. of Health, Education, and Welfare, National Institute of Occupational Safety and Health HEW/NIOSH Criteria for a Recommended Standard... Occupational Exposure to Alkanes (C5-C8), Públication No. 77-151, March 1977.

U.S. Dept. HEW/NIOSH, Criteria for a Recommended Standard... Occupational Exposure to Asphalt Fumes, Publication No. 78-106, September 1977.

U.S. Dept. HEW/NIUSH, Crlterla for a kécommended Standard... Occupational Exposures in Coal Gasification Plants, PublicationNo. 78-191, September 1978.

U.S. Dept. HEW/NIOSH, Criteria for a Recommended Standard... Occupational Exposure to Coal Tar Products, Publication No. 78-107, September 1977.

U.S. Dept. HEW/NIOSH, Criteria for a Recommended standard... Occupational Exposure to Carbon Black, Publication No. 78-204, September 1978 . 
U.S. Dept. HEW/NIOSH, Criteria for a Recommended standard... Occupational Exposure to Vanadium, Publication No. 77-222, August 1977.

U.S. Environmental Protection Agency, Office of Research and Development, Energy/Environment III, EPA-600/9-78-022, October 1978 .

Wei, G. C. et. al., Impact of Alternate Fuel on Industrial Refractories and Refractory Insulation Applications, An Assessment, ORNL-TM-5592. Prepared by Oak Ridge National Laboratories for ERDA, September 1976.

Weir, A., Alternate Fuels for Power Generation, Society of Automotive Engineers, 770672, August 1977.

White, C. M. et. al., Combined Gas Chromatographic-Mass Spectrometric Analysis of Nitrogen Bases in Light Oil From a coal Liquefaction product, Fuel Processing Technology, I (1977/1978) 290-215, Elsevier Scientific Publishing Co., Amsterdam, Netherlands. 